\title{
Violence in Nigeria
}

A qualitative and quantitative analysis

Marc-Antoine Pérouse de Montclos (ed.)

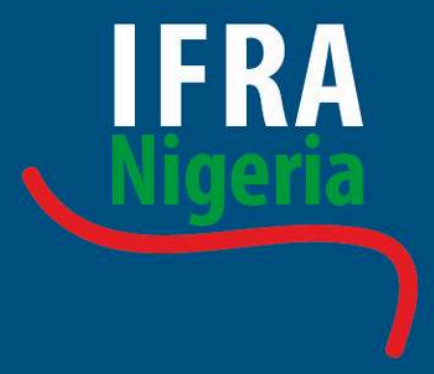

African Studies Centre

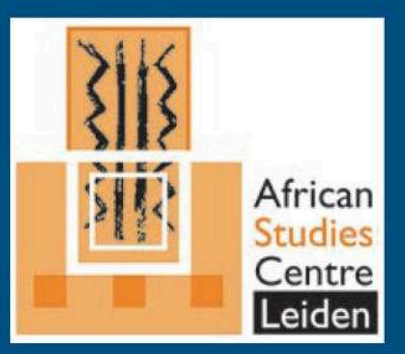




\section{IFRA-Nigeria}

French Institute for Research in Africa, Nigeria | Institut français de

IFRA-Nigeria

recherche en Afrique, Nigeria

\section{Violence in Nigeria}

A qualitative and quantitative analysis

\section{Marc-Antoine Pérouse de Montclos (dir.)}

DOI: 10.4000/books.ifra.1705

Publisher: IFRA-Nigeria, African Studies Centre

Place of publication: Ibadan

Year of publication: 2016

Published on OpenEdition Books: 22 July 2021

Series: WAPOSO Series

Electronic EAN: 9791092312553

\section{OpenEdition}

\section{Books}

https://books.openedition.org

\section{Printed version}

Date of publication: 1 January 2014

EAN (Print version): 9789054481492

Number of pages: xiv-217

\section{Electronic reference}

PÉROUSE DE MONTCLOS, Marc-Antoine (ed.). Violence in Nigeria: A qualitative and quantitative analysis. New edition [online]. Leiden, Ibadan: IFRA-Nigeria, 2016 (generated 28 janvier 2022). Available on the Internet: <http://books.openedition.org/ifra/1705>. ISBN: 9791092312553. DOI: https://doi.org/ 10.4000/books.ifra.1705.

(c) IFRA-Nigeria, 2016

Creative Commons - Attribution-ShareAlike 4.0 International - CC BY-SA 4.0 


\section{ABSTRACTS}

Most of the academic literature on violence in Nigeria is qualitative. It rarely relies on quantitative data because police crime statistics are not reliable, or not available, or not even published. Moreover, the training of Nigerian social scientists often focuses on qualitative, cultural, and political issues. There is thus a need to bridge the qualitative and quantitative approaches of conflict studies. This book represents an innovation and fills a gap in this regard. It is the first to introduce a discussion on such issues in a coherent manner, relying on a database that fills the lacunae in data from the security forces. The authors underline the necessity of a trend analysis to decipher the patterns and the complexity of violence in very different fields: from oil production to cattle breeding, radical Islam to motor accidents, land conflicts to witchcraft, and so on. In addition, they argue for empirical investigation and a complementary approach using both qualitative and quantitative data. The book is therefore organized into two parts, with a focus first on statistical studies, then on fieldwork.

\section{MARC-ANTOINE PÉROUSE DE MONTCLOS (DIR.)}

Marc-Antoine Pérouse de Montclos teaches at the French Institute of Geopolitics, University of Paris 8. He is also an Associate Fellow, Africa Programme, Chatham House and a Global Fellow of the Peace Research Institute in Oslo (PRIO).

\section{EDITOR'S NOTE}

The digital book is also available at the Leiden University Repository: http:// hdl.handle.net/1887/37759.

The printed book can be ordered at the ASC webshop: http://www.ascwebshop.nl/ Webwinkel-Product-141323151/Violence-in-Nigeria.-A-qualitative-and-quantitativeanalysis.html 


\section{Violence in Nigeria}

A qualitative and quantitative analysis

Marc-Antoine Pérouse de Montclos (ed.)

\section{IFRA}

African Studies Centre

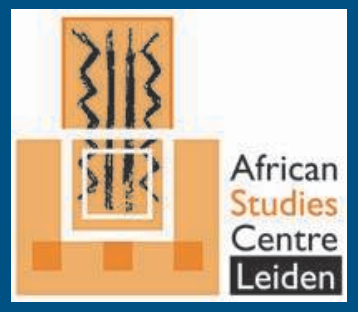





\section{Violence in Nigeria: "A qualitative and quantitative analysis"}



African Studies Centre (ASC)

Institut Français de Recherche en Afrique (IFRA)

West African Politics and Society Series, Vol. 3

\section{Violence in Nigeria: "A qualitative and quantitative analysis"}

Edited by

Marc-Antoine Perouse de Montclos 
Published by:

African Studies Centre

P.O. Box 9555

2300 RB Leiden

asc@ascleiden.nl

www.ascleiden.nl

French Institute for Research in Africa / Institut Français de Recherche en Afrique (IFRA-Nigeria)

University of Ibadan

Ibadan, Oyo State

Nigeria

www.ifra-nigeria.org

Cover design: Heike Slingerland

Cover photo: Marc-Antoine Pérouse de Montclos

Printed by Ipskamp Printing, Enschede

ISSN: 2213-5480

ISBN: 978-90-5448-149-2

(C) Marc-Antoine Pérouse de Montclos, 2016 


\section{Contents}

LIST OF FIGURES vii

LIST OF MAPS viii

LIST OF TABLES $i x$

LIST OF ABBREVIATIONS $x$

LIST OF CONTRIBUTORS $x i i$

FOREWORD xiii

INTRODUCTION: ARGUMENTS FOR A QUALITATIVE AND QUANTITATIVE ANALYSIS OF VIOLENCE IN NIGERIA 1

Marc-Antoine Pérouse de Montclos

PART 1 TRENDS, PATTERNS AND MAPPING: A QUANTITATIVE ANALYSIS OF VIOLENCE IN NIGERIA

1 TRENDS AND PATTERNS OF FATAL ROAD ACCIDENTS IN NIGERIA (2006-2014) 13

Vitus Nwankwo Ukoji

2 PATTERNS AND TREND ANALYSIS OF VIOLENCE IN OIL PRODUCTION AND OIL DISTRIBUTION IN NIGERIA (2006-2014) 41 Adeola Adams

3 TRENDS AND PATTERNS OF CATTLE GRAZING AND RURAL VIOLENCE IN NigERIA (2006-2014) 61

Philip Ademola Olayoku

4 TRENDS AND PATTERNS OF FATALITIES RESULTING FROM CULT SOCIETIES AND BELIEF IN WITCHCRAFT IN NIGERIA (2006-2014) 77 Akinpelu Babajide Adedotun

5 Muslims, Christians AND RELIGIOUS ViolenCE IN Nigeria:

PATTERNS AND MAPPING (2006-2014) 91 Akinola Ejodame Olojo

6 KILLINGS BY THE SECURITY FORCES IN NIGERIA: MAPPING AND TREND ANALYSIS (2006-2014) 112

Super Odomovo Afeno 
PART 2 FIELDWORK AND SURVEYS: A QUALITATIVE ANALYSIS OF VIOLENCE IN NIGERIA

7 A SURVEY OF VIOLENCE-RELATED DEATHS IN ANINRI AND ISI-UZO LGAS OF ENUGU STATE (2006-2014) 143 Joachin Uche Okanume

8 A SURVEY OF VIOLENCE-RELATED DEATHS IN EGBEDORE AND IFEDAYO LGAS OF OSUN STATE (2006-2014) 161 Hammed Abodunrin

9 A STUDY OF VIOLENCE-RELATED DEATHS IN BAURE, INGAWA, KURFI, Mani, AND MataZU LGAs of Katsina State (2006-2014) 179 Adam Alqali

10 A STUDY OF VIOLENCE-RELATED DEATHS IN GUdU, GWADABAWA AND ILLELA LGAs of SoKoto State, AND SAKABA LGA of KebBi StATE (2006-2014) 195

Arshad Munir \& Akinola Ejodame Olojo

POSTSCRIPT: THE NEXT CHALLENGE: STATISTICS AS A TOOL FOR HUMAN SECURITY 219 


\section{List of figures}

1.1 FRSC and Nigeria Watch records of fatalities caused by road accidents (2007-2013) 20

1.2 Cumulated figures of violent deaths in Nigeria, by cause (June 2006May 2014) 22

1.3 Vehicle types and road accidents in Nigeria (June 2006-May 2014) 25

1.4 Fatal road accidents by days of the week (June 2006-May 2014) 29

1.5 Number of violent deaths in Nigeria caused by road accidents, by state (June 2006-May 2014) 30

1.6 Number of violent deaths in Nigeria caused by road accidents, by region (June 2006-May 2014) 36

1.7 Number of motor vehicles registered in Nigeria (2007) 36

2.1 Physical flow of products: Retail route used by Major and Independent Marketers in Nigeria 45

2.2 Annual number of deaths caused by oil distribution (June 2006-May 2014) 50

2.3 Deaths due to oil distribution, by state (June 2006-May 2014) 51

2.4 Violent deaths caused by oil production (June 2006-May 2014) 54

2.5 Number of deaths resulting from oil production, by state (June 2006May 2014) 55

3.1 Violent deaths in Nigeria caused by cattle grazing, per year (June 2006May 2014) 65

3.2 Violent deaths caused by cattle grazing in Nigeria, by state, cumulated figures (June 2006-May 2014) 70

3.3 Violent deaths in Nigeria caused by cattle grazing, cumulative figures per month (June 2006-May 2014) 73

4.1 Number of violent deaths in Nigeria, by protagonist, cumulated figures (June 2006-May 2014) 83

4.2 Number of violent deaths in events where cult societies were involved, by state, cumulated figures (June 2006-May 2014) 86

4.3 Violent deaths caused by political issues in events where cult societies were involved (June 2006-May 2014) 86

4.4 Number of violent deaths in Nigeria caused by sorcery, per year (June 2006May 2014) 87

4.5 Number of violent deaths caused by political issues, per year (June 2006May 2014) 88

5.1 Absolute number of violent deaths per year (June 2006-May 2014) 96

5.2 Violent deaths caused by religious issues, per year (June 2006-May 2014) 97

5.3 Violent deaths involving Islamic and Christian groups, per year (June 2006May 2014) 101

6.1 Number of violent deaths resulting from incidents where the security forces intervened, per year (June 2006-May 2014) 120

6.2 Number of violent deaths resulting from incidents where the security forces intervened, by type of relationship (June 2006-May 2014) 123

6.3 Number of violent deaths resulting from incidents where the army intervened, per year (June 2006-May 2014) 124 
6.4 Number of violent deaths resulting from incidents where the police intervened, per year (June 2006-May 2014) 125

6.5 Number of violent deaths resulting from incidents where the police intervened, by type of relationship (June 2006-May 2014) 127

6.6 Frequency of security forces killings in selected states (June 2006-May 2014) 131

6.7 Frequency of security forces killings, by perpetrators, in selected states (June 2006-May 2014) 132

6.8 Percentages per month of the total fatalities caused by the security forces during the 2007 general elections 136

6.9 Percentages per month of the total fatalities caused by the security forces during the 2011 general elections 137

7.1 Percentage of violent deaths per year in Aninri LGA (June 2006-May 2014) 145

7.2 Percentage of violent deaths per year in Isi-Uzo LGA (June 2006-May 2014) 145

7.3 Percentage of causes of violent deaths in Aninri LGA (June 2006-May 2014) 154

7.4 Percentage of causes of violent deaths in Isi-Uzo LGA (June 2006-May 2014) 159

\section{List of maps}

1.1 Fatalities caused by road accidents in Nigeria (June 2006-May 2014) 23

1.2 Fatality rates related to road accidents in Nigeria, per 100,000 inhabitants (June 2006-May 2014) 24

2.1 Fatalities resulting from oil distribution in Nigeria (June 2006-May 2014) 52

2.2 Fatality rates resulting from oil distribution in Nigeria, per 100,000 inhabitants (June 2006-May 2014) 53

2.3 Fatalities resulting from oil production in Nigeria (June 2006-May 2014) 56

2.4 Fatality rates resulting from oil production in Nigeria, per 100,000 inhabitants (June 2006-May 2014) 57

3.1 Fatalities caused by cattle grazing in Nigeria (June 2006-May 2014) 70

3.2 Fatality rates caused by cattle grazing in Nigeria, per 100,000 inhabitants (June 2006-May 2014) 71

4.1 Fatality rates caused by sorcery in Nigeria, per 100,000 inhabitants (June 2006May 2014) 84

4.2 Fatalities in events where cult societies were involved in Nigeria (June 2006May 2014) 88

5.1 Fatalities caused by religious issues in Nigeria (June 2006-May 2014) 98

6.1 Fatalities resulting from incidents where the security forces intervened in Nigeria (June 2006-May 2014) 128

7.1 Invisible violence in some selected LGAs 142 


\section{List of tables}

1.1 Severity index of fatal road accidents, by state (June 2006-May 2014) 26

1.2 Number of violent deaths in Nigeria caused by road accidents, per month (June 2006-May 2014) 27

1.3 Yearly breakdown of violent road accident deaths in Nigeria (June 2006May 2014) 31

1.4 Summary of fatal car accidents in Lagos, by LGA and route (June 2006May 2014) 32

1.5 Summary of fatal car accidents in Edo, by LGA and route (June 2006May 2014) 33

1.6 Summary of fatal car accidents in FCT (Abuja), by LGA and route (June 2006May 2014) 35

1.7 Population of main cities and number of deaths caused by road accidents (June 2006-May 2014) 38

4.1 Number of male and female victims killed because of the belief in sorcery, Nigeria (June 2006-May 2014) 82

4.2 Number of adults and children killed because of the belief in sorcery, Nigeria (June 2006-May 2014) 82

5.1 Frequencies of violent death incidents involving Muslims and Christians (religious and non-religious issues) (June 2006-May 2014) 103

5.2 Violent deaths of Christian clerics due to Islamist (mainly Boko Haram)-related attacks (June 2006-May 2014) 104

5.3 Violent deaths of Islamic clerics due to Islamist (mainly Boko Haram)-related attacks (June 2006-May 2014) 107

7.1 Demographic characteristics of respondents in Aninri LGA 148

7.2 Violent events recorded in Aninri LGA (June 2006-May 2014) 149

7.3 Demographic characteristics of respondents in Isi-Uzo LGA 155

7.4 Violent events recorded in Isi-Uzo LGA (June 2006-May 2014) 156

8.1 Violence types and fatalities in Egbedore LGA (November 2009-June 2014) 170

8.2 Violence types and fatalities in Ifedayo LGA (December 2009-September 2014) 173

9.1 Violent deaths in Baure LGA (2006-2014) 184

9.2 Violent deaths in Kurfi LGA (2006-2014) 185

9.3 Violent deaths in Mani LGA (2006-2014) 186

9.4 Violent deaths in Matazu LGA (2006-2014) 188

9.5 Violent deaths in Ingawa LGA (2006-2014) 189

10.1 Demographics of respondents in Gudu, Gwadabawa, Illela, and Sakaba LGAs 199

10.2 Violent incidents in Gudu LGA (June 2006-May 2014) 200

10.3 Violent incidents in Gwadabawa LGA (June 2006-May 2014) 204

10.4 Violent incidents in Illela LGA (June 2006-May 2014) 209

10.5 Violent incidents in Sakaba LGA (June 2006-May 2014) 213 


\begin{tabular}{|c|c|}
\hline $\mathrm{ACN}$ & Action Congress of Nigeria \\
\hline AIT & Africa Independent Television \\
\hline ANPP & All Nigeria Peoples Party \\
\hline APC & All Progressives Congress \\
\hline APGA & All Progressives Grand Alliance \\
\hline CENTECS & Centre for Ethnic and Conflict Studies \\
\hline CJTF & Civilian Joint Task Force \\
\hline COCIN & Church of Christ in Nigeria \\
\hline $\mathrm{CPC}$ & Congress for Progressive Change \\
\hline $\mathrm{DCO}$ & Divisional Crime Officer \\
\hline DPO & Divisional Police Officer \\
\hline DPP & Democratic People's Party \\
\hline DPR & Department Petroleum Resources \\
\hline DSS & Department of State Security \\
\hline EW & Early warning \\
\hline FCE & Foundation for Co-Existence \\
\hline FGD & Focus group discussion \\
\hline FRSC & Federal Road Safety Commission \\
\hline IAS & Institute of African Studies \\
\hline ICCES & Inter-Agency Consultative Committee on Election Security \\
\hline ICT & Information and Communication Technology \\
\hline IFRA & Institute for Research in Africa \\
\hline ILRI & International Livestock Research Institute \\
\hline IM & Independent Marketer \\
\hline JASLWJ & Jama'atu Ahlis Sunna Lidda'awati wal-Jihad \\
\hline JTF & Joint Task Force \\
\hline KII & Key informant interview \\
\hline LGA & Local Government Area \\
\hline MACBAN & Miyetti Allah Cattle Breeders Association of Nigeria \\
\hline MASSOB & Movement for the Actualisation of the Sovereign State of Biafra \\
\hline MEND & Movement for the Emancipation of the Niger Delta \\
\hline MNJTF & Multi-National Joint Task Force \\
\hline MOM & Major Oil Marketer \\
\hline NAN & News Agency of Nigeria \\
\hline NARTO & National Association of Road Transport Owners \\
\hline NBC & National Broadcasting Commission \\
\hline NBER & National Bureau of Economic Research \\
\hline NBS & National Bureau for Statistics \\
\hline NDI & National Democratic Institute \\
\hline NDLEA & National Drug Law Enforcement Agency \\
\hline NDPVF & Niger Delta People's Volunteer Force \\
\hline
\end{tabular}




$\begin{array}{ll}\text { NDV } & \text { Niger Delta Vigilante } \\ \text { NHRC } & \text { National Human Rights Commission } \\ \text { NLDP } & \text { National Livestock Development Project } \\ \text { NNPC } & \text { Nigeria National Petroleum Corporation } \\ \text { NOPRIN } & \text { Network on Police Reform in Nigeria } \\ \text { NPC } & \text { National Population Commission } \\ \text { NPF } & \text { Nigeria Police Force } \\ \text { NSA } & \text { National Security Adviser } \\ \text { NSCDC } & \text { Nigeria Security and Civil Defence Corps } \\ \text { NSRP } & \text { Nigerian Stability and Reconciliation Programme } \\ \text { NUJ } & \text { Nigeria Union of Journalists } \\ \text { NULGE } & \text { Nigeria Union of Local Government Employees } \\ \text { NURTW } & \text { National Union of Road Transport Workers } \\ \text { NYSC } & \text { National Youth Service Corps } \\ \text { OECD } & \text { Organization for Economic Co-operation and Development } \\ \text { OIC } & \text { Organisation of Islamic Conference } \\ \text { OMPADEC } & \text { Oil Minerals Producing Areas Development Commission } \\ \text { PCS } & \text { Peace and Conflicts Studies } \\ \text { PDP } & \text { People's Democratic Party } \\ \text { PIB } & \text { Petroleum Industry Bill } \\ \text { PIND } & \text { Partnership Initiatives in the Niger Delta } \\ \text { PMS } & \text { Premium Motor Spirit } \\ \text { POWA } & \text { Police Officers Wives Association } \\ \text { PPMC } & \text { Pipeline and Product Marketing Company } \\ \text { PPPRA } & \text { Petroleum Products Pricing Regulatory Authority } \\ \text { PRIO } & \text { Peace Research Institute in Oslo } \\ \text { RSTC } & \text { Rivers State Transport Company } \\ \text { RTC } & \text { Road Traffic Crashes } \\ \text { SAP } & \text { Structural Adjustment Policy } \\ \text { SCID } & \text { State Criminal Investigation Department } \\ \text { SSATP } & \text { Sub-Saharan Africa Transport Policy Program } \\ \text { SSS } & \text { State Security Service } \\ \text { STF } & \text { Special Task Force } \\ \text { UN } & \text { United Nations } \\ \text { WHO } & \text { World Health Organization } \\ & \end{array}$




\section{List of contributors}

Hammed Abodunrin has an MA in Peace and Conflict Studies at the Institute of African Studies, University of Ibadan, Nigeria. Contact: hammedabodunrin@yahoo.com

Adeola Adams is the Project Coordinator of Nigeria Watch. He has a $\mathrm{PhD}$ in Peace and Conflict Studies and a graduate degree in Political Science, both obtained at the University of Ibadan. Contact: adams.nwifra@gmail.com

Akinpelu Babajide Adedotun has an MA in Peace and Conflict Studies, University of Ibadan. He presently works as a Research Officer with Education Liaison Office, Nigeria Security and Civil Defence Corps. Contact: emailbabajide@yahoo.com

Super Odomovo Afeno was the Project Assistant Coordinator of Nigeria Watch and an IFRA-Nigeria Research Fellow. He has an MSc in Political Science from the University of Ibadan. He now works for PIND, the Foundation for Partnership Initiatives in the Niger Delta. Contact: afenomovo@yahoo.co.uk

Adam Alqali is a freelance journalist. Contact: aalqali@gmail.com

Arshad Munir, PhD is a Senior Lecturer at the Sokoto State University, Sokoto, Nigeria. Contact: amleghari@gmail.com

Joachin Uche Okanume is an Associate Researcher at the Centre for Ethnic and Conflict Studies (CENTECS), University of Port Harcourt, Choba, Rivers State. Contact: ucheokanume@gmail.com

Philip Ademola Olayoku has a PhD in Peace and Conflict Studies at the University of Ibadan, Nigeria. Contact: iyanda22000@yahoo.co.uk

Akinola Ejodame Olojo is a $\mathrm{PhD}$ candidate at the Université Paris Descartes, France. Contact: akinolojo@gmail.com

Marc-Antoine Pérouse de Montclos teaches at the French Institute of Geopolitics, University of Paris 8 . He is also an Associate Fellow, Africa Programme, Chatham House and a Global Fellow of the Peace Research Institute in Oslo (PRIO).

Contact: perouse@ird.fr

Vitus Nwankwo Ukoji is an Information Retrieval Specialist at Nigeria Watch and a Research Fellow at the French Institute for Research in Africa (IFRA-Nigeria). He has an MSc in Peace and Conflict Studies. Contact: ukojiv@gmail.com 


\section{Foreword}

The challenge of managing violent conflicts in Nigeria has been complicated by the dearth of accurate and reliable data on the incidence and impact of violence. Conflict management institutions and actors do not have access to information on the number of incidents of violence, the number of deaths due to violence, and the amount of property lost as a result of violence. The result is that policy and practice on conflict management and peacebuilding are based on assumptions and speculations about such numbers. Consequently, it is a challenge to assess the impact of initiatives to prevent and manage violent conflict. This challenge was apparent to the designers of the Nigeria Stability and Reconciliation Programme (NSRP) as they sought to set baselines for the interventions considered useful for addressing violent conflicts in Nigeria. There was no national database that tracked, collated, and disseminated information on violent conflict in a systematic way. During the search for baseline data, the designers of the NSRP came across a promising initiative which tracked incidents of violent deaths in the country. However, the initiative was based in a Paris institute and initiated by the French Africanist and political scientist Marc-Antoine Perouse de Montclos. There were no indications that Nigerian actors and institutions were aware of the database or used its data for research and policy purposes.

It was against this background that NSRP decided to support the development and domestication of the Nigeria Watch project. Funding for the project, which is an initiative of the UK Department for International Development, facilitated the transfer of the Nigeria Watch database to the University of Ibadan. As a result of NSRP support, the database is now domiciled in Nigeria and maintained by Nigerian researchers and data analysts. It has also correspondingly become more accessible to more Nigerians. The NSRP support to Nigeria Watch has also aimed to facilitate use of the data collated for research. Consequently, grants from NSRP have supported research which has used the Nigeria Watch database to explain different aspects of violent deaths in Nigeria. This book is the product of some of the grants awarded to young Nigerian scholars interested in the study of violence. It applies qualitative and quantitative data to explain the incidence and impact of violence. By combining qualitative and quantitative data for analysis, the chapters in the book provide well-grounded empirical bases for analysis and conclusions. The qualitative studies help us to understand the statistics by shedding more light on the facts behind the figures. We congratulate Dr. MarcAntoine Pérouse de Montclos and his colleagues at IFRA and Nigeria Watch for 
their work on this publication, and it is hoped that this book will serve as a catalyst for more systematic studies of violence in Nigeria.

Dr Ukoha Ukiwo

Nigeria Stability and Reconciliation Programme (NSRP)

Abuja 


\title{
Introduction: Arguments for a qualitative and quantitative analysis of violence in Nigeria
}

\author{
Marc-Antoine Pérouse de Montclos
}

At first, some of the reports appeared frightening but, in the course of time, I got used to alarms that no longer made any serious impact on me. It is debatable whether or not familiarity with serious security reports, helps the President or any Chief Executive in his administration.

Former Nigerian President Alhaji Shehu Shagari, commenting on the daily bulletins of the National Security Organisation. ${ }^{1}$

Nigeria has a reputation for being a very violent country. In 2014, it was considered to be the seventeenth most fragile state in the world, and it was ranked 151 out of 162 countries in the Global Peace Index, a multidimensional report on violence, security, and criminality. ${ }^{2}$ This is a cause for alarm, and researchers obviously have a role to play in the private and public debates on insecurity. However, many academics claim that crime is on the rise without relying on any data other than some scattered evidence. Most of the literature on violence in Nigeria is qualitative. It rarely relies on quantitative data for a simple reason: police crime statistics are not reliable, or not available, or not even published. Moreover, the training of Nigerian social scientists often focuses on qualitative, cultural, and political issues. The French Institute for Research in Africa (IFRA) has been a pioneer in promoting research on urban violence in Nigeria, yet there is still a need to bridge the qualitative and quantitative approaches of conflict studies.

This book fills a gap in this regard. First, it underlines the necessity of a trend analysis to decipher the patterns and the complexity of violence in very different fields: from oil production to cattle breeding, radical Islam to motor accidents, land conflicts to witchcraft, and so on. Secondly, it argues for a complementary approach using both qualitative and quantitative data. Statistics, as such, are inert, of little use, and prone to manipulation; they require an empirical investigation to make sense. ${ }^{3}$ Thus, statistics cannot be accurate if they are not cross-

\footnotetext{
Shagari, Alhaji Shehu (2001), Shehu Shagari: Beckoned to Serve - An Autobiography, Ibadan, Heinemann Educational Books, p. 327.

2 See: http://www.visionofhumanity.org/\#/page/indexes/global-peace-index

See also: http://library.fundforpeace.org/library/cfsir1423-fragilestatesindex2014-06d.pdf.

3 Pérouse de Montclos, Marc-Antoine, Elizabeth Minor \& Samrat Sinha, ed., Violence, statistics, and the politics of accounting for the dead, Dordrecht, Springer, 2016.
} 
checked and enriched by fieldwork studies. Moreover, it is the qualitative and intuitive understanding of violence that helps to build a coherent database of incidents and develop reliable analysis.

This book is therefore organized into two parts, with a focus first on statistical studies, then on fieldwork. With the support of the Nigerian Stability and Reconciliation Programme (NSRP), the contributors each received a grant from IFRA to write their chapters. Their work uses a database that has archived reports of fatal incidents and monitored human security in Nigeria since 1 June 2006. Established on the campus of the University of Ibadan, the project is called Nigeria Watch and celebrates its tenth anniversary with the release of this book. It relies on a thorough reading of the Nigerian press and reports from human rights organizations to compile and record fatalities on a daily basis, including deaths resulting from accidents. The purpose of the project is to address the general lack of data with regard to violence in Nigeria and its victims.

Indeed, crime statistics in Nigeria are inadequate. While posing an important problem in Nigeria and being often used rhetorically for political gains by officials, the evolution of violence in the country has never been properly quantified. Since the military era, the Nigerian security forces have remained secretive and reluctant to release data on their operations. Regarding the Boko Haram insurgency since July 2009, for instance, the military have arrested and killed many people but refused to return the bodies to the families so as to avoid the possible initiation of legal proceedings against the security forces. ${ }^{4}$ In August 2012, they also instructed the mortuaries in Maiduguri, the birthplace of the sect, not to maintain records, possibly in an effort to conceal the high rate of deaths in detention. ${ }^{5}$ As for Boko Haram, the insurgents usually conceal the bodies of their dead combatants so as to maintain the myth of their invincibility.

In such a difficult context, the Nigeria Watch project aims to compile data consistently and over the long term in order to identify dangerous areas in Nigeria and to interpret the trends, patterns, and changes in violence, based on an analysis of the data collected. However, it does not claim to be exhaustive. Moreover, its sources often differ when it comes to the number of casualties. ${ }^{6}$ Because it relies on the media, Nigeria Watch does not cover equally the Nigerian territory either, as shown in the second part of this book. It is thus important to be aware of the limits of quantitative studies. Generally speaking, Africa is ac-

4 Amnesty International (2015), Stars on Their Shoulders. Blood on Their Hands. War Crimes Committed by the Nigerian Military, London, Amnesty International, p. 74.

In the same vein, the Burundi Red Cross was pressed in May 2015 to stop publishing communiqués on the number of casualties resulting from the military repression of demonstrations against the incumbent president.

6 In the online system, figures are updated whenever a new source provides a different report, which explains why trends may change slightly according to the current state of data when they are accessed. Any errors in the following chapters remain the sole responsibility of the authors. 
customed to poor numbers shaping how decisions are made. ${ }^{7}$ Except for a few countries, population and economic data are often unreliable. Moreover, statistics are frequently subject to political manipulation and bias. Finally, they can be ignored even by institutions that live off statistics. In a recent report, for instance, the World Bank and the French Development Agency speculate on a "rise in violence and conflict in West Africa since 2010", when the figures they published actually show a dramatic decline of fatalities from organized violence since 1998-1999. ${ }^{8}$

The most populated country in Africa is of course affected by these issues. In Nigeria, the numbers of inhabitants, internally displaced people, Muslims, Christians, victims of terrorism and of the security forces are all disputed to produce electoral rolls, negotiate a share of the so-called national cake, complain about ethnic marginalization, 'alert the international community' ... or claim that Allah or Jesus is the winner! As early as 1966, for instance, Odumegwu Ojukwu inflated the number of Igbo people killed or displaced by pogroms in the North, so as to justify the secession of the Eastern Region in $1967 .{ }^{9}$ The Catholic fathers, who supported the rebels, also claimed that the monthly death toll of the Nigerian blockade against Biafra was exceeding 750,000 people in 1968 , a statement that would have resulted in 9 million fatalities in just a year, almost the total number of inhabitants living in the area. ${ }^{10}$ Even today, the body count of war victims is still a hotly debated issue in determining whether or not the atrocities and deliberate starving of civilians were a genocide. ${ }^{11}$ Likewise, the Boko Haram uprising

7 Jerven, M. (2013), Poor Numbers: How We Are Misled by African Development Statistics and What to Do about it, Cape Town, UCT Press, 208 pp. See also Pérouse de Montclos, M.-A., E. Minor \& S. Sinha, eds, (2015), Violence, Statistics, and the Politics of Accounting for the Dead, Dordrecht, Springer, p. 160.

8 Marc, A., N. Verjee \& S. Mogaka (2015), The Challenge of Stability and Security in West Africa, Washington DC, World Bank, pp.1 \& 10.

9 Gould, M. (2011), The Struggle for Modern Nigeria: The Biafran War, 1966-1970, London, IB Tauris, p. 47, 142 \& 203; Niven, R. (1970), The War of Nigerian Unity, 1967-1970, Totowa (N.J.), Rowman and Littlefield, p. 93.

10 Mok, M. (1969), Biafra Journal: A Personal Report on a People in Agony, New York, Time-Life Books, p. 95.

11 Going beyond militant points of views, Lasse Heerten and Dirk Moses argue that, in fact, an accusation of genocide would be difficult to sustain on behalf of an invented group like Biafra, which included non-Igbo minorities such as the Ogoni, who themselves claimed to be victims of a genocide perpetrated by the Igbo. Moreover, Igbo people living in Nigeria outside Biafra were not exterminated during the war; in the same vein, survivors within the Biafran enclave were not killed after the end of the war. The accusation of an intention to destroy Biafra or Igbo people by starvation through blockade is also difficult to sustain, because the Biafran authorities rejected offers to enable the delivery of supplies that did not suit their military objectives. Ironically, fearing that genocide was taking place or would occur if Biafra lost, Western support of Biafran resistance and thereby prolongation of the war dramatically increased the civilian losses that the secession and foreign aid were intended to prevent. Finally, most genocides intend to expel and eradicate a group; yet the government of Nigeria aimed to preserve a federation by including the Igbo against their will. See Heerten, L. \& Moses, D. (2014), The Nigeria-Biafra War: Postcolonial Conflict and the Question of Genocide, Journal of Genocide Research 16(2-3): 169-203. 
has been a matter of contest. Some Biafra militants thus argued that in 2012 a total of 3 million Igbos were stranded in the city of Kano because of the threats of the jihadist group on Christian minorities in the North. ${ }^{12}$ In a city which is predominantly Hausa, this figure is actually higher that the total number of inhabitants $(2,830,000)$ reported by the 2006 census.

Politics is not the only cause of interference with statistics; humanitarian advocacy also plays a role. As long as they can impress the public, many nongovernmental organizations (NGOs) do not care much about accurate numbers. For instance, one of them claimed that Boko Haram killed 1,000 people in 20102013 , a figure that a few pages later in the same report was stated to be $7,000{ }^{13}$ In most cases, the media and human rights NGOs do not distinguish between the victims of the sect and the victims of the security forces. The total number is presented as the body count of those killed only by Boko Haram. A report for the European Parliament thus confused the two categories to claim that the sect killed over 22,000 people between July 2009 and July 2014, supposedly 'a conservative estimate' and including 2,000 deaths in $2014 .{ }^{14}$ In fact, even the authorities in Borno acknowledged that over 1,000 people lost their lives because of the government military repression in July 2009. ${ }^{15}$ Except for a few incidents, Boko Haram was then silent until it attacked the central prison of Bauchi in September 2010. In other words, the European Parliament's 'guesstimates' meant that in 2011-2013 alone, the insurgents killed an average of 6,000 people per year, an impressive figure that was never corroborated by field reports.

In comparison, the detailed data of Nigeria Watch gave a total number of victims of the conflict as 685 in 2011; 1,482 in 2012; 3,004 in 2013; and 11,811 in 2014 , the year when military operations fully developed. The perpetrators of the killings could not be identified in many cases, but the security forces were clearly responsible for a large number of them. Investigations have shown that they extra-judicially executed more than 1,200 suspects, while at least 7,000 died in military detention between 2011 and 2015, including 4,700 in 2013 as a result of illtreatment alone: torture, starvation, extreme overcrowding, suffocation, and denial of medical assistance. ${ }^{16}$ This is notwithstanding some 1,200 people who were

12 See for instance Ebiem, O. (2014), Nigeria, Biafra and Boko Haram. Ending the Genocides Through Multistate Solution, New York, Page Publishing, p. 66.

13 Barkindo, A., B. Tyavkase Gudaku \& C. Katgurum Wesley (2013), Our Bodies, Their Battleground. Boko Haram and Gender-Based Violence against Christian Women and Children in North-Eastern Nigeria Since 1999, Harderwijk, Open Doors International, Nigeria's Political Violence Research Network, pp. 9 \& 13.

14 Barna, J. (2014), Insecurity in Context: The Rise of Boko Haram in Nigeria, Brussels, European Parliament, p. 9.

15 Galtimari, Usman Gaji, ed., (Oct. 2009), Report of the Administrative Committee of Inquiry into the Boko Haram Insurgency in Borno State, Maiduguri, Borno State, 5 vols.

16 Amnesty International (2015), Stars on Their Shoulders, Blood on Their Hands: War Crimes Committed by the Nigerian Military, London, Amnesty International, pp. 4, 58 \& 86. 
arrested and disappeared. As for Boko Haram, it killed some 6,800 people from January 2013 to March 2015, mostly civilians according to Amnesty International. The organization had to rely on individual witnesses to assess the situation. Its figure included 1,350 civilians killed in more than 100 attacks in 2013, over 4,000 in 230 raids in 2014, and 1,500 in the first three months of 2015; but an appendix to the report listed precise details only for 817 civilians killed as a result of 46 bomb attacks from January 2014 to March 2015 . $^{17}$

\section{Structure of the book}

The chapters of this book are evidence-based and are illustrated by maps drawn by Hugo Lefebvre. They do not speculate on 'guesstimates', relying instead on hard facts. In the first part, the authors use statistics extracted from the Nigeria Watch dataset to analyse the trends and patterns of violence during a period of eight years, from 1 June 2006 to 31 May 2014. The media and decision makers usually focus on terrorism. In Nigeria, however, the killings perpetrated by Boko Haram and the security forces occur mainly in three out of 36 states: Borno, Yobe, and Adamawa. The rest of the Nigerian Federation follows another pattern, in which accidents appear to be the major cause of violent death. Nationwide perceptions are not so different in this regard. In March 2015, a survey by NOI Polls (an organization founded by the former managing director of the World Bank, Ngozi Okonjo-Iweala) revealed that Nigerians identified 'Sickness' (26\%), 'Poverty' (24\%), and 'Motor accidents' (16\%) as leading causes of death.

In the Chapter 1, based on a sample of 15,090 fatalities in eight years, Vitus Ukoji thus analyses the magnitude of fatalities resulting from road accidents. Nigeria is ranked second in the world for the rate of such accidents, and the roads are one of the main causes of fatalities in the country. Because of its large population, Lagos is the most affected state. Nationwide, more people $(55 \%)$ die in the South, which has more registered vehicles, than in the North (45\%). However, the capital city Abuja records a high ratio of fatalities resulting from motor accidents compared with the number of its inhabitants, as this city has more vehicles registered per capita.

Accidents are also a major cause of death in the oil industry. When it comes to what is the economic backbone of Nigerian industry, the media usually focus on violent protests against transnational corporations like Shell. From 2006 until the government amnesty of 2009, the uprising of the Movement for the Emancipation of the Niger Delta (MEND) was indeed striking, with sabotage, pipeline

17 Amnesty International (2015), 'Our Job is to Shoot, Slaughter and Kill'. Boko Haram's Reign of Terror in North-East Nigeria, London, Amnesty International, pp. 9, 26 \& 32. 
blasts, terrorist attacks, and kidnappings. Yet Adeola Adams shows in Chapter 2 that oil distribution is much more lethal than oil production. The reasons are not difficult to understand. First, oil production is restricted to a few states in the Niger Delta area, while oil distribution activities cover the whole nation. Moreover, oil production deals essentially with crude oil, which is less volatile than the highly inflammable refined products involved in oil distribution. Finally, oil distribution has a strong link with tanker and road accidents, which are rated as one of the main contributors to fatalities in Nigeria.

In this respect, it is no coincidence that the most deadly incident ever recorded by Nigeria Watch was a pipeline explosion and a fire of refined products that killed 628 residents in Lagos in December 2006. Before that, such accidents had already devastated many areas. Pipeline explosions killed 150 people at Atlas Creek Island in Lagos State in May 2006; 120 in the village of Amiyi-Uhu near Umuahia in Abia State in June 2003; and 250 and 200 in Jesse near Warri in July 2000 and October 1998, respectively. These incidents often involve the Nigeria National Petroleum Corporation (NNPC), which is in charge of refineries and oil distribution all over the country, as in Amiyi-Uhu. Interestingly enough, such disasters occur both in rural and urban areas.

Typically, however, fatal incidents caused by other issues follow very different patterns in towns and in the countryside. From a methodological point of view, one of the problems is also that the media often under-report news in rural areas. In Chapter 3, Philip Ademola Olayoku thus had to analyse fatal conflicts related to cattle grazing from a small sample of 111 cases in eight years. He shows that clashes between pastoralists and farmers are usually related to land disputes. Most of these clashes involve Fulani cattle breeders. Such cases are more prevalent in northern Nigeria, yet they record a higher number of casualties in states like Plateau, Benue, and Cross River. Interestingly, these clashes reveal no cyclic pattern; contrary to conventional wisdom, they follow no season and can occur at any time of the year.

In fact, some cultural patterns of violence also transcend the rural-urban divide. Beliefs in witchcraft or religious allegiances concern peasants and city dwellers alike, yet with some formal differences related to the landscape and the way of life. In Chapter 4, Akinpelu Babajide Adedotun investigates deaths attributed to sorcery, cultism, and ritual killings, including the lynching of suspected sorcerers. Women and children, he shows, constitute an important proportion of the victims, even if men and adults still represent the majority. However, the study reveals that witchcraft accounted for only $1 \%$ of the total number of fatalities reported in the Nigeria Watch database during the period under review. Moreover, most deaths attributed to sorcery and cult societies occurred in the southern part of the country. In the North, eight states did not experience any rit- 
ual killings. As for the link between politics and cult societies, it remains vague and nebulous. Like many Africans, Nigerians actually tend to overemphasize sorcery as a major source of misfortune and fear.

Religion is another issue that affects both rural and urban dwellers. In Nigeria, many observers believe that there is a 'clash of civilizations' between Muslims in the North and Christians in the South. However, Akinola Ejodame Olojo shows in Chapter 5 that fatal incidents between rival Islamic groups are more prevalent than those between Muslims and Christian organizations. A second major point is that violence involving religious groups is not always caused by religious issues. Many fatal incidents recorded by the Nigeria Watch database between Islamic and Christian groups are not related to religious issues. Thirdly, it remains inconclusive whether or not more Muslims than Christians (or vice versa) are killed because of violence in general in Nigeria. Finally, the Western media frames violence in Nigeria as being mainly inter-religious, while lethal incidents between rival Islamic groups are largely under-reported.

The Boko Haram crisis has certainly exacerbated the fear of a war of religion. Yet the state security forces are also very much involved in the war on terrorism in north-eastern Nigeria. In Chapter 6, Super Odomovo Afeno shows that the intervention of the police and the army often exacerbates a situation and results in more people being killed. Between June 2006 and May 2014, for instance, the Nigerian security forces caused fatalities in $59 \%$ of the lethal incidents in which they intervened throughout Nigeria. Killings by the police were more numerous, while the army caused more fatalities per incident. Also, the security forces intervened more often in the South, but caused more fatalities in the northern part of the country.

\section{Invisible violence: Rural case studies and fieldwork}

Many factors may lead to lethal violence, and this book does not aim at reviewing them all. Lack of space also forced us to leave aside other working papers of the Nigeria Watch project, which can be accessed online and which deal with such topics as violence against women, land disputes, maritime piracy, clashes within and between political parties, electoral struggles, the role of oil companies, and population pressure in the Niger Delta. ${ }^{18}$ Whatever the case, research on lethal conflicts and accidents certainly requires qualitative investigation. Fieldwork and semi-structured interviews with stakeholders are even more necessary when fatal incidents are not reported by the media, especially in remote rural areas that are difficult to access. The Nigeria Watch database, for instance, has no

18 http://www.nigeriawatch.org/index.php?html=12 
records of lethal violence in some of the 774 Local Government Areas (LGAs) of the Nigerian Federation, either because these LGAs are very peaceful or, more probably, because they are not covered by the media. ${ }^{19}$

Hence, the second part of this book investigates 'invisible' violence through four case studies, two each for the South and the North. In the relevant LGAs, all rural, surveys were conducted to document violence-related deaths during the same time frame as the period covered by the previous chapters based on the statistics of the Nigeria Watch dataset from 1 June 2006 to 31 May 2014. Their findings complement the quantitative studies of the first part of this book.

In Chapter 7, Joachin Uche Okanume Survey begins with a survey of violence-related deaths in Aninri and Isi-Uzo LGAs of Enugu State. These areas are predominantly inhabited by farmers and traders; however, their pattern of violence is not very different from the other regions of Nigeria if we make an exception for the North-East and the Boko Haram crisis. In Aninri, for instance, the majority of fatal incidents result from motor accidents, while crime is the second leading cause of fatalities. In the case of Isi-Uzo, crime is the leading cause of fatalities. Lack of development partly explains these differences locally, as IsiUzo has almost no roads. This lack of development also provides a clue to the reluctance of the national press to report news in rural LGAs that have no economic value, lack urban centres, and are difficult to access, such as Isi-Uzo.

In Chapter 8, Hammed Abodunrin studies Egbedore and Ifedayo LGAs of Osun State. Residents, he finds, do not consider these areas to be violent; however, some fatal incidents were reported over land disputes, police clashes, and personal attacks. Like most regions of Nigeria, motor accidents accounted for the majority of violent deaths in Egbedore and Ifedayo, mainly because of bad roads, according to respondents. Interviews conducted with journalists in Osun also revealed a number of reasons for the media not adequately covering such rural areas. There were claims of bad roads, poor transportation services, and irregular salaries, which hindered the ability of journalists to visit remote parts of the state. In addition, journalists pointed to the lack of community newspapers and the different media house styles, which saw some stories as not weighty enough to make national news. Finally, they stressed the uncooperative attitude of security operatives in regard to releasing information.

In Chapter 9, Adam Alqali takes us to the north of Nigeria to investigate lethal violence in Baure, Ingawa, Kurfi, Mani, and Matazu LGAs of Katsina State. His research reveals 37 fatal incidents in unreported cases of violence, which resulted

19 By 1 November 2014, these were the following: Udung Uko and Urue-Offong/Oruko (Akwa Ibom); Kwaya Kusar (Borno); Nafada (Gombe); Auyo, Gagarawa, Kaugama, and Yankwashi (Jigawa); Ingawa and Matazu (Katsina); Sakaba (Kebbi); Bassa, Igalamela-Odolu, and Mopa-Muro (Kogi); Toto (Nassarawa); Ifedayo (Osun); Gudu and Gwadabaw (Sokoto); Ussa (Taraba); and Karasuwa, Machina, Nguru, and Yunusari (Yobe). 
in 104 deaths between 2006 and 2014. Accidents, again, were the main cause of fatalities. In order of prevalence, road accidents were responsible for $64 \%$ of the deaths, followed by drowning (13\%), famer-pastoralist clashes (7\%), building collapses $(5 \%)$, murders $(4 \%)$, fire outbreaks $(3 \%)$, animal attacks $(2 \%)$, explosions $(1 \%)$, and electrocutions $(1 \%)$. Yet these incidents did not make news headlines. For Alqali, the political economy of the media in Nigeria explains this gap because private owners underpay journalists and see news organs as political platforms to manipulate the unsuspecting masses, to the detriment of poor and marginalized groups in rural areas.

Finally, in Chapter 10, Arshad Munir and Akinola Ejodame Olojo document violence-related deaths in Gudu, Gwadabawa, and Illela LGAs of Sokoto State, and in Sakaba LGA of Kebbi State. With a total of 1,047 fatalities in the areas under review between 2006 and 2014, data obtained from 1,083 questionnaires revealed a very high prevalence of lethal incidents in a rural region of northwestern Nigeria which is usually seen as quite peaceful compared with large cities such as Kano, Kaduna and, of course, Maiduguri. Gudu actually recorded the highest number of fatalities and incidents, while Sakaba had the lowest. For the period under review, the most frequent cause of fatal incidents was cattle grazing, followed by political clashes. Religion, which is often perceived as a major factor of conflict, contributed quite insignificantly to the overall level of violence in the four LGAs, with a few incidents involving the Yan Shi'a brotherhood, the Tijaniyya Sufi order, and the Yan Izala movement. In conclusion, the study demonstrates that, just as in the urban centres of Sokoto and Kebbi, there are many fatal incidents that go unreported in rural areas.

Reporting, recording, and monitoring thus remain a challenge to properly understanding violence. In the current context, the ten-year old Nigeria Watch project should indeed continue and develop further, pending the support of its partners. There is no reason to stop it, because records are always necessary to assess the evolution of human security when it comes to homicides, accidents, massacres, terrorist attacks, and so forth. Moreover, the Nigeria Watch project can provide an interesting alternative to citizens who have no access to unpublished or unreliable police statistics.

\section{Dr Marc-Antoine Pérouse de Montclos}

Senior Researcher, Institut de Recherche pour le Développement, Paris

Associate Fellow, Africa Programme, Chatham House, London

PRIO Global Fellow (Peace Research Institute in Oslo) 

Part I

Trends, patterns and mapping: A

quantitative analysis of violence in Nigeria 



\title{
Trends and patterns of fatal road accidents in Nigeria (2006-2014)
}

\author{
Vitus Nwankwo Ukoji
}

\begin{abstract}
The incidence of fatal road accidents in Nigeria is staggering. Trend analysis of fatal road accidents between June 2006 and May 2014 using Nigeria Watch database shows that 15,090 lives were lost to fatal road accidents in 3,075 events. The highest number of fatalities occurred in 2013 (2,061 deaths), a 2.8\% increase over the 2012 record of 1,652 deaths. However, the probability of a high fatality record in 2014 remains high considering the 964 deaths already recorded between January and May 2014. On the national scene, Lagos recorded the highest number of fatalities, while FCT (Abuja) has the highest relative number of deaths per 100,000 population. These findings are explained by the large population and continuous urbanization of Lagos and by the number of registered vehicles in the FCT (Abuja). On the regional level, a trend analysis shows that more people died in fatal road accidents in the South than in the North. Among other factors, a greater number of motor vehicles, the volume of oil distribution, and the occurrence of highway criminal activities explain why there are more fatal road accidents in the South than in the North.
\end{abstract}

\section{Introduction}

The $19^{\text {th }}$ century industrial revolution resulted in some fundamental changes in the transport sector ${ }^{1}$ and provided more flexibility of movement, speed, and timing. Since then, there has been an upsurge in both human and vehicular motor movement, a situation that has also resulted in more fatal road accidents. The worst-hit are developing countries, a circumstance confirmed by Tawia AddoAshong, World Bank Global Road Safety Facility Coordinator, when she said that 1.2 million die yearly from road traffic accidents. ${ }^{2}$

http://en.wikipedia.org/wiki/Transport

Favour Nnabugwu, 2014, 1.2 M Dead in Road Accidents - World Bank chief, Vanguard, June 15. 
A study carried out by Chen thus show that the fatality rate in African countries ranges from 10-fold to more than 100-fold that in the United States. ${ }^{3}$ Also, Lagarde reported that Africa has an average rate of 28.3 per 100,000 populationroad traffic mortality compared with 11 in Europe. ${ }^{4}$ Sub-Saharan African Transport Policy, in its report, quoted an increase of road fatalities in Africa by $350 \%$ between 1990 and $1998 .{ }^{5}$ Most of those affected by fatal car accidents are young people. One may wonder why a less motorized Africa has such a high record of fatal road accidents.

Concerns about the rising incidence of fatal road accidents propelled stakeholders, including the United Nations (UN) Assembly, into seeking means to curb road fatalities. On 11 May 2011, the UN adopted the period 2011-2020 as the UN Decade of Action for Road Safety, during which all efforts will concentrate on stabilizing and then reducing global road traffic fatalities by 2020. According to the UN Secretary General, Ban Ki-Moon, lives will be saved through this decade of action. ${ }^{6}$ Following the declaration by the UN in 2011, the Federal Road Safety Commission (FRSC) in Nigeria set out to adopt and domesticate the $\mathrm{UN}$ action plan by developing a number of programmes suitable for every road user in the country.

Despite integrated efforts towards reducing fatal road accidents, Nigeria still remains one of the worst-hit countries. With a human population of approximately 167 million, a high level of vehicular population estimated at over 7.6 million, and a total road length of about 194,000 km (comprising 34,120 km of Federal, $30,500 \mathrm{~km}$ of state, and $129,580 \mathrm{~km}$ of local roads), ${ }^{7}$ the country has suffered severe losses to fatal car accidents. Its population density varies in rural (51.7\%) and urban areas (48.3\%), and this translates into a population-road ratio of 860 persons per sq $\mathrm{km}$, indicating intense traffic pressure on the available road network. ${ }^{8}$ Undoubtedly, this immense pressure contributes to the high number of road traffic accidents in the country (FRSC 2012).

Nigeria is ranked second-highest in the rate of road accidents among 193 countries of the world. ${ }^{9}$ Oladepo and Brieger (1986) argued that three-quarters of

Chen, G. (2010), Road Traffic Safety in African Countries - Status, Trend, Contributing Factors, Counter Measures and Challenges, International Journal of Injury Control and Safety Promotion 17(4): 247-255.

4 Lagarde, E. (2007), Road Traffic Injury Is an Escalating Burden in Africa and Deserves Proportionate Research Efforts, PLoS Medicine 4(6): 967-71

Ibid.

6 A speech at the launch of the event, UN Secretary General by Ban Ki-Moon on May 11, 2011 during the United Nations Assembly.

7 Sumaila, AbdulGaniyu Femi, 2013. Road Crashes Trends and Safety Management in Nigeria, Department of Transport Management Technology, Federal University of Technology, Minna.

Ibid.

9 Agbonkhese, O., G.L. Yisa, E.G. Agbonkhese, D.O. Akanbi, E.O. Aka \& E.B. Mondigha (2013), Road Traffic Accidents in Nigeria: Causes and Preventive Measures. Civil and Environmental Research, ISSN 2224-5790 (Paper) ISSN 2225-0514 (Online), Vol. 3, No. 13. 
all accidents on Nigerian roads involve fatalities. ${ }^{10}$ Aside from the Boko Haram crisis, accidents are currently by far the main cause of violent death in Nigeria. ${ }^{11}$ The WHO adjudged Nigeria the most dangerous country in Africa with 33.7 deaths per 100,000 population every year. ${ }^{12}$ According to their report, one in every four road accident deaths in Africa occurs in Nigeria. The WHO survey and the FRSC report of 5,693 fatal road accidents in $2009^{13}$ leave no doubt about the dangerous situation on Nigerian roads.

The causes of fatal car accidents in Nigeria have been categorized into human, mechanical, and environmental factors. According to Umar, the human factor accounts for up to $90 \%$ of accidents, while the mechanical and environmental factors contribute the other $10 \% .{ }^{14}$ Human factors include visual acuteness, driver fatigue, poor knowledge of road signs and regulations, illiteracy, health problems, excessive speeding, drug abuse, and over-confidence while at the steering wheel. Among the mechanical factors that lead to fatal car accidents are poor vehicle maintenance, tyre blowouts, poor lights, un-roadworthy vehicles, and broken-down vehicles without adequate warning to others on the road. The environmental factors include heavy rainfall, Harmattan winds, sun reflection, heavy wind, pot-holes, and untarred roads. These factors have independently and/or collectively contributed to the high rate of fatal road accidents in Nigeria.

The repercussions of such accidents have been colossal. Despite the happiness and change of quality of family lives associated with owning a vehicle, its possession has left many families bereft of their breadwinners or loved ones. ${ }^{15} \mathrm{Ac}$ cording to Adekunle, the socio-economic costs of road traffic accidents in Nigeria are immense, and the direct costs of traffic casualties can perhaps be understood best in terms of the labour lost to the nation's economy. ${ }^{16}$ This was further developed by Pratte, who argued that persons injured in accidents on Nigerian highways and streets no longer participate in the economic mainstream, and this amounts to a loss of labour of millions of person-years to the nation. ${ }^{17}$

In February 1988, the Federal Government established the FRSC through Decree No. 45 (1988) to reduce road mishaps. This was later amended by Decree 35 (1992) and is referred to in the statute books as the FRSC ACT cap 141, Laws of

10 Oladepo, O. \& R. Brieger (2006), Road Traffic Accidents: Applying the Brake to a Killing Tree.

Pérouse de Montclos, M.-A., Nigeria Watch: Fourth Report on Violence in Nigeria (2006-2014).

12 WHO 2013 Report on Accidents in Africa.

13 FRSC (2009). Traffic Digest, A Transport Digest Publication of PRS Department.

14 Ibid.

15 Dr. Murtala Muhammad Umar, Road Transport Accidents: Causes, Effects and Prevention, General Hospital Zurmi, Zamfara State.

16 Adekunle, J.A. (2010), Road Traffic Accident Deaths and Socio-Economic Development in Nigeria. Int. Rev. Bus. Soc. Sci. 1(5): 47-60.

17 Pratte, D. (1998), Road to Ruin: Road Traffic Accident in the Developing World, NEXUS 13: 46-62. 
the Federation of Nigeria (Nigerian Constitution 1999). ${ }^{18}$ To achieve its objective, the commission compiles comprehensive data on road traffic accidents, including injuries and deaths - unlike Nigeria Watch database, which deals only with violent deaths, including those caused by accidents. It is therefore imperative to draw conclusions after a comparative analysis of data from the FRSC and Nigeria Watch.

\section{Contexts of road accidents in Nigeria}

Different circumstances precipitate fatal car accidents in Nigeria. Understanding these contexts (political and socio-economic) gives one a better understanding of why road accident has remained a leading cause of death in the country.

\section{Political contexts}

Fatal road accidents in Nigeria cannot be directly attributed to politics. However, party activities, governance, budgetary allocations, contract evaluation, and so on have a direct impact on the rate at which accidents occur. The attempts of government ministries and parastatals to reduce the number of accidents have usually been frustrated by poor funding. The Federal Ministry of Works and the FRSC suffer from apparent severe budgetary constraints, leading to insufficient human and material resources and untimely acquisition of safety equipment. Furthermore, bureaucratic logjams and politicization of contract awards are rife with irregularities and inflated costs. This leads to situations where road contracts are not properly executed.

Government functionaries and party leaders have been identified as protagonists in fatal road accidents in Nigeria. The indiscriminate use of sirens, coupled with high-speed driving by political public office holders, including governors and their convoys, has caused several road traffic accidents. A renowned Nigerian academician, Professor Iyayi, died in an accident that involved the convoy of Kogi State Governor Captain Idris Wada, who on 28 December 2012 was involved in another fatal accident along the Lokoja-Ajaokuta Road, which killed his aide de camp, Assistant Superintendent of Police Idris Mohammed. Similarly, the convoy of Governor Oshiomole of Edo State was involved in a gruesome car accident, leading to the death of three reporters, while returning from a party function in April 2012 where some members of the People's Democratic Party (PDP) were being received into the now defunct Action Congress of Nigeria $(\mathrm{ACN})$. In the same year, three political aides of Governor Al-Makura of Na-

18 Agbeboh G. U. \& Osabuohien-Irabor Osarumwense (2013), Empirical Analysis of Road Traffic Accidents: A Case Study of Kogi State, North-Central Nigeria, Department of Mathematics, Ambrose Alli University, Ekpoma, Nigeria. 
sarawa State were killed in a multiple car crash involving the governor's convoy along the Gadabuke-Keffi Road in the state. Governor Abdul Aziz Yari was involved in a fatal car accident in 2012 that claimed the life of a police officer attached to his team. In Katsina in 2011, the aide de camp to State Governor Ibrahim Shema and four others died in a road accident that involved the governor's convoy, just 48 hours after two people died when their vehicle was involved in an accident while travelling in the convoy of Niger State Governor Babangida Aliyu for a campaign rally. The list is likely to be added to if nothing is done to manage convoys' recklessness and careless driving.

\section{Economic contexts}

The rapid development of comprehensive road transportation is crucial to the economy of every nation. Opportunities to acquire and sell a variety of commodities necessary for industrial and manufacturing systems are expanded by a wellcoordinated transport system. Oni (2004) argued that transport is a key element in the social and economic development of any nation. The restrictive nature of the waterways in Nigeria, the pitiful condition of the rail system, and the inability of the average Nigerian to afford the high cost of air travel make road transportation preferable in the country. In 2006, 644,387 vehicles, including government motor cars and motorcycles, private motor cars and motorcycles, and commercial motor cars and motorcycles, were registered nationwide. The number fell in 2007 to 612,867 but increased in 2008 to 746,814 and to 777,835 in 2009. In 2010, 712,938 vehicles were registered. ${ }^{19}$ Over $70 \%$ of the total movements of the registered vehicles in the country and about $80 \%$ of the freight movements take place on the road. ${ }^{20}$ The over-dependence on road transportation worsens the condition of roads, involves huge pressure on motorists, and causes many fatal road accidents.

The discovery of oil in Nigeria opened new frontiers of economic engagement. Statistics from the National Bureau for Statistics (NBS) (2010) show that the crude petroleum sub-sector accounts for over $80 \%$ of Nigeria's foreign exchange. The distribution of refined oil products across the country has been a thorn in the side of many Nigerians. In 2011, the FRSC reported that Nigeria had an average of approximately 5,000 tankers involved in wet cargo haulage, moving about 150 million litres of fuel, and 2,500 'trailers' in dry cargo plying Nigeria's roads dai1y. ${ }^{21}$ Kayode also revealed that between 2007 and June 2010, a total of 4,017 tanker/trailer crashes were recorded on Nigerian roads, with a yearly average of 1,148 crashes, monthly average of 96 crashes, and a total of 4,076 persons killed

19 National Bureau Of Statistics (2009), Annual Abstract Of Statistics

20 FRSC (2011), Traffic Digestion

21 Ibid. 
in such crashes involving tankers and trailers. ${ }^{22}$ Due to the highly inflammable nature of Premium Motor Spirit (PMS), fatal accidents involving petrol tankers have usually been lethal.

Aside from the carnage of fire explosions involving petrol tankers, articulated vehicles have also significantly contributed to fatal road accidents in Nigeria. Trucks and trailers transport agricultural goods and industrial equipment to various locations by road. According to statistics from the NBC (2010), over $60 \%$ of the Nigerian population are engaged in agriculture. ${ }^{23}$ In 2006, about 99,030 metric tons of major agricultural crops were produced in Nigeria. The number fell in 2007 to 97,183 metric tons and in 2008 to 95,097 , then increased again in 2009 to 96,050 and to 115,424 in $2010 .{ }^{24}$ Transporting these products in trucks via roads plagued with pot-holes and congestion has caused several fatal road accidents.

In pursuit of extra profit, commercial vehicle owners task their drivers with generating more profit, a situation that leads to careless driving and driver exhaustion. According to Olusiyi, most commercial drivers are paid daily wages of N1,000-2,500, depending on the city and the type of vehicle, a wage which drivers consider meagre. After daily or weekly accounting, such drivers are left with low incomes, which cannot adequately sustain them and their families. ${ }^{25}$ Under such circumstances, vehicles are not properly maintained. The risk of being injured, according to Agbonkhese et al. (2013), increases exponentially with speed, and the severity of accidents depends on the transfer of kinetic energy at impact. ${ }^{26}$ In an attempt to increase their productivity and therefore remuneration, drivers tend to drive as fast as possible in their poorly maintained vehicles. The result is more accidents and more fatal accidents.

\section{Social contexts}

Poverty remains a circumstantial factor in the occurrence of fatal road accidents in Nigeria and may not be directly linked to it. Poor housing conditions, social isolation, overloading of passengers in slum areas, insecurity in public places, and several other variables explain why the risk of fatal road accidents remains high among low-income earners in Nigeria. Their living conditions are in sharp contrast with those of their richer fellow-citizens, who reside in metropolitan areas with overhead bridges, secured playgrounds, and greater traffic control and

22 Kayode Olagunju, 19 October 2010. Corps Commander Corps Transport Standardization Officer, Federal Road Safety Corps, National Headquarters, Pmb 125, Abuja, Nigeria.

23 National Bureau for Statistics (2010).

24 Ibid.

25 Ipingbemi, O. (2008), Socio-Economic Characteristics and Driving Behaviour of Commercial Drivers in Southwestern Nigerian Cities. Lyon, CODATU (Cooperation for Urban Mobility in the Developing World), 5 pp.

26 Ibid. 
safety measures. Christie argued that a link between social deprivation and high accident rate may be explained in terms of increased exposure to hazardous environments. ${ }^{27}$ This assumption was expanded by Abdalla, who argued that the casualty rates among residents from areas classified as relatively deprived are significantly higher than among those from relatively affluent areas. ${ }^{28}$ Schools located within slum areas lack overhead bridges, and pupils and pedestrians are left at the mercy of careless drivers. Instances were seen in Anambra and Lagos, where school children were crushed to death while trying to cross an expressway. When parents cannot afford the huge fees paid by high-income earners, they have to send their children to slum schools, where they are exposed to fatal road accidents

Population density is another social factor that influences the frequency of fatal road accidents in large cities. Slum areas are mostly congested with peoples and vehicles. Lack of space is worsened by the abandonment of car wrecks along the roads. When drivers scramble for space, they often cause fatal road accidents when they manoeuvre around obstacles or other road users. Safety measures are ignored and people are killed. The cities of Lagos, Kano, Rivers, and Ibadan frequently experience fatal road accidents owing to their high number of inhabitants and socio-economic activities.

Personal relationships, family issues, and financial problems are elements that increase the frequency of fatal road accidents. A driver's capacity to attend to hazards is essentially defined by his state of mind. Phone conversation while driving, social interaction, and peer influence undermine drivers' sense of judgment and the speed of their responses. These in-vehicle distractions increase the likelihood of entirely missing critical events such as changes in traffic lights. ${ }^{29}$ Furthermore, drivers who are in the grip of negative emotions and stress arising from factors in their social backgrounds exhibit a high level of distraction, experience impaired observation skills, and fail to read road signs. Such distractions frequently lead to fatal accidents.

\section{Comparing FRSC data on fatal road accidents with Nigeria Watch data}

The FRSC, as mentioned earlier, was established in 1988 as a result of the continuous increase in the number of fatal road accidents in Nigeria. It has the aim of

27 Christie, N. (1995b), Social, Economic and Environmental Factors in Child Pedestrian Accidents: A Research Review. Transport Research Laboratory, Project Report 116.

28 Abdalla, I.M. (1997), Statistical Investigation and Modelling of the Relationships Between Road Accidents and Social Characteristics. PhD Thesis, Napier University.

29 Hancock, P.A., M. Lesch \& L. Simmons (2003), The Distraction Effects of Phone Use During a Crucial Driving Maneuver. Accident Analysis and Prevention (35) 501-514 
reducing road traffic crashes and creating a safe motoring environment. ${ }^{30}$ To achieve these objectives, the commission relies on research. It has built a strong database on road crashes with a view to putting the findings to use to achieving safer roads. Using information and communication technology (ICT) for effective surveillance to capture and monitor data has been transformed into evidencebased facts to address road problems. The commission regularly publishes briefs in its Road Mirror.

Figure 1.1 FRSC and Nigeria Watch records of fatalities caused by road accidents (2007-2013)

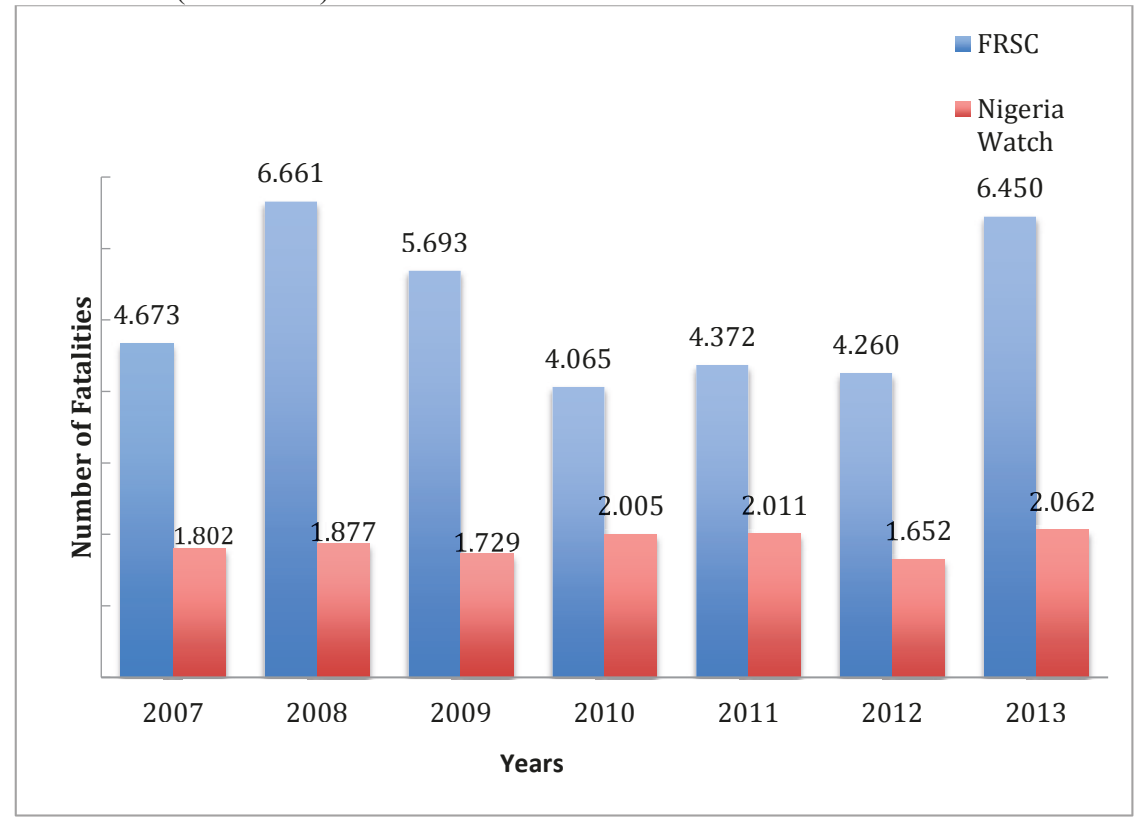

The Nigeria Watch online database has performed a similar task to the FRSC since the former's establishment in June 2006. Unlike FRSC's operation of a more advanced database on both fatal and non-fatal road accidents, however, Nigeria Watch focuses only on accidents that involve at least one death. Between 2006 and 2013, the FRSC recorded 41,118 deaths from road accidents, while Nigeria Watch recorded only 14,300. Despite these differences and a more restricted dataset, Nigeria Watch helps to monitor the trends and patterns of reported

30 FRSC (2007), An article on FRSC Establishment Act. www.frsc.gov.ng. 15 December 2007. 
fatal road accidents because it records more details on each accident recorded than the official statistics of the FRSC.

\section{Methods and materials}

Nigeria Watch data focus on reported accident cases involving at least one death between June 2006 and May 2014 in ten Nigerian daily newspapers. The data exclude non-fatal injuries. Road accidents fall under a broad category of accidents involving cars, buses, tankers, lorry/trailers, bicycles, tricycles, and trains. Extracting data that relates to the above-mentioned categories requires an eventby-event analysis. General causes of violent deaths within the period under review were analysed in order to identify the most deadly violent event. To establish the trends in fatal road accidents, secondary data was collated from the FRSC and compared with Nigeria Watch's data. Fatal road accidents were grouped by year, region, state, city, severity index, and most dangerous route. The essence of categorizing the data extraction was to establish the patterns of fatal road accidents nationwide. Also, the relative number of deaths was calculated in order to determine the probability of someone dying from road accident per 100,000 population. The severity index was calculated by comparing the number of people killed with the number of fatal crashes. Search results were generated from the Nigeria Watch database and exported to Excel for classification. The results are presented in bar charts and frequency distribution tables.

\section{Methodological challenges}

Despite the consistency in news reportage in Nigeria, there is a probability that some fatal car accidents, especially those that occur in rural villages, are not reported. This challenge calls into question the validity of the records of fatal road accidents when compared with FRSC data, which usually have triple the numbers found in the Nigeria Watch data on fatal road accidents (Figure 1.1).

\section{Causes of violent deaths in Nigeria}

Many Nigerians have lost their lives in violent events. Such events cut across regions and ethnic identities. Figure 1.2 shows the main causes of violent deaths between June 2006 and May 2014. 
Figure 1.2 Cumulated figures of violent deaths in Nigeria, by cause (June 2006-May 2014)

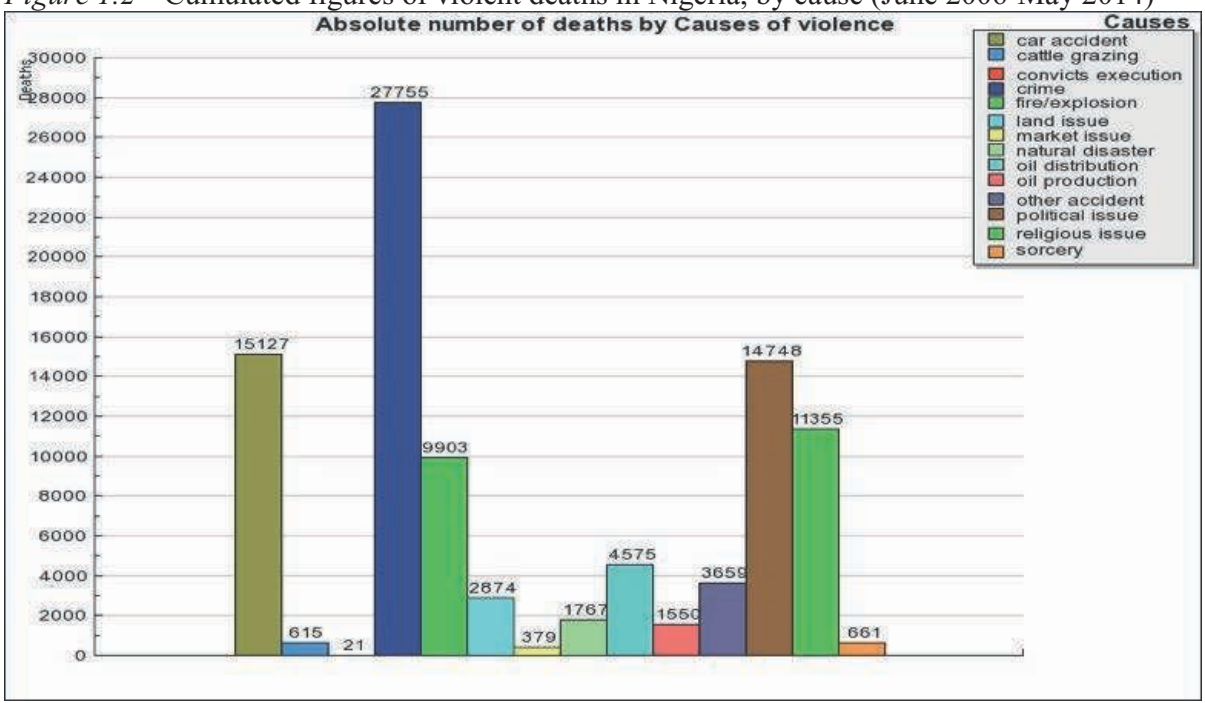

Approximately 61,090 people lost their lives in 14,087 events nationwide during the period under review. ${ }^{31}$ In order of public importance, accidents of various types, including road accidents, recorded the highest number of deaths in total, followed by crime, political violence, ethno-religious matters, and economic issues. Apart from the Boko Haram crisis in the North-East, accident is thus the main cause of violent deaths in Nigeria. Over 15,000 lives were lost to fatal road accidents involving cars, buses, tankers, and others articulated vehicles in 3,075 events between June 2006 and May 2014. Data from Nigeria Watch show that Lagos State recorded the highest number of fatalities, with 1,543 car accident deaths, followed by Edo with 1,201 deaths, and FCT (Abuja) with 1,026 deaths. While fatal car accidents had declined in Lagos in 2014 up to the end of May, Abuja still has the highest relative number of deaths per 100,000 inhabitants.

\section{Mapping of fatal road accidents in Nigeria}

It is thus relevant to study the trends in car accidents. This mapping covers the period between June 2006 and May 2014. Lagos State recorded 620 crashes; Edo, 177; and FCT (Abuja), 348. While the highest number of fatal car accidents occurred in Lagos, Abuja had the highest relative number of deaths per 100,000 population, as can be seen in Map 1.1 and 1.2.

31 This figure is lower than the total number of casualties tabulated for each cause of violence in Figure 1.2. This is because fatalities can result from several causes, and hence some duplicates in Figure 1.2. 
Map 1.1 Fatalities caused by road accidents in Nigeria (June 2006-May 2014)

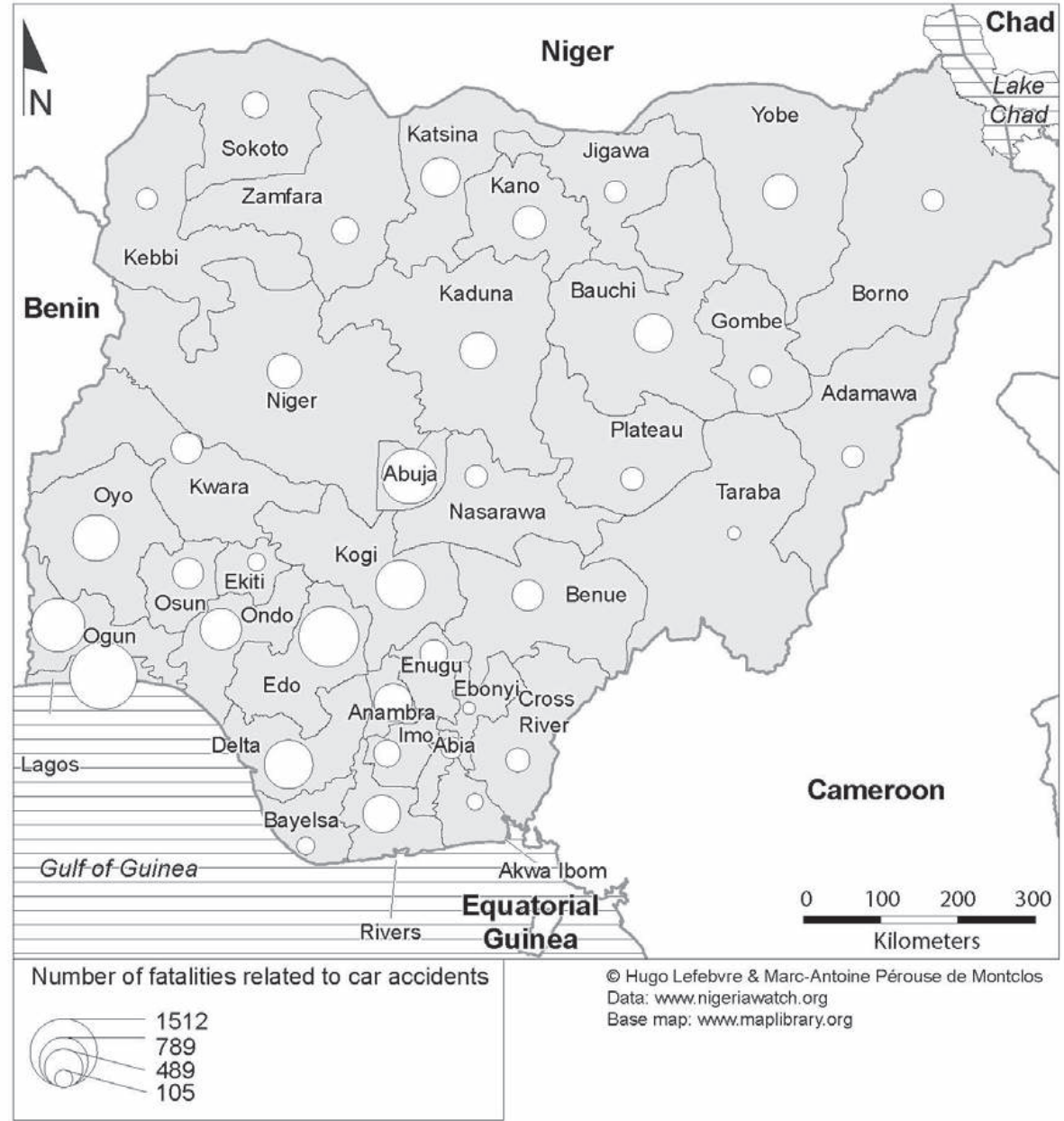


Map 1.2 Fatality rates related to road accidents in Nigeria, per 100,000 inhabitants (June 2006-May 2014)

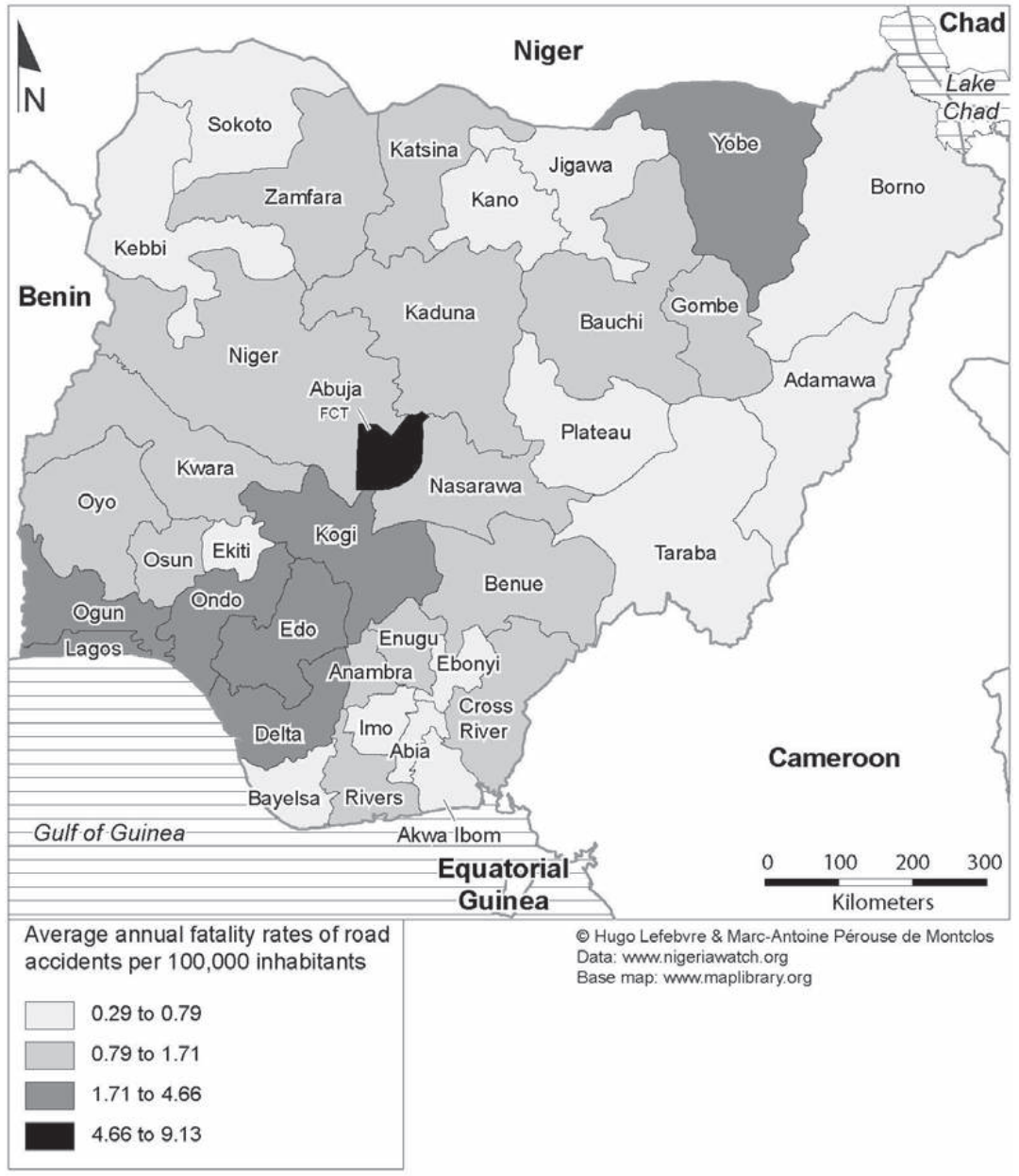

\section{Fatal road accidents by vehicle type}

Different vehicles are involved in fatal car accidents. Figure 1.3 shows the categorization of such vehicles. 
Figure 1.3 Vehicle types and road accidents in Nigeria (June 2006-May 2014)

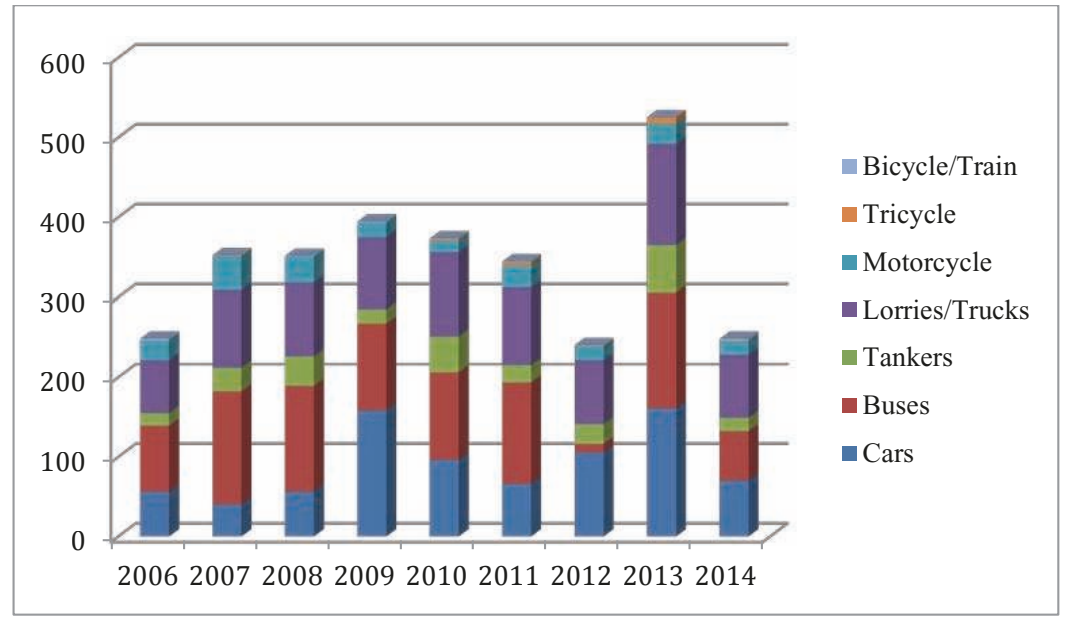

The results in Figure 1.3 show a total of 921 bus crashes between June 2006 and May 2014, including 142 in 2007, 133 in 2008, 109 in 2009, 110 in 2010, 127 in 2011, 11 in 2012, and 144 in 2013. Luxury and mini-buses are the most preferred means of travel for inter-city transportation in Nigeria, and fatal accidents involving them are the most prevalent on highways. Second in order of prevalence were accidents involving lorries and trucks, with 833 fatal crashes. About 15\% (127) of such crashes occurred in 2013. Undoubtedly, lorries and trucks are crucial to the economic growth of the nation. Most agrarian communities in Nigeria rely on trucks and lorries to ferry their agricultural products to cities. Like buses, accidents involving trucks and lorries are reported mostly on the highways.

Car crashes are third in order of prevalence. Cars are popular means of intracity transportation in Nigeria. While many of them are registered for private use and for use as city cabs, others are used for inter-city transportation. However, poor maintenance and inability to observe safety measures often lead to fatal accidents. Between June 2006 and May 2014, there were 808 incidents of fatal car accidents. Accidents involving cars are reported mostly in metropolitan areas.

Results in Figure 1.3 also show that 270 fatal crashes involving tankers occurred between June 2006 and May 2014: 16 in 2006; 30 in 2007; 37 in 2008; 18 in 2009; 45 in 2010; 22 in 2011; 25 in 2012; and 60 in 2013. By the end of May 2014, 17 crashes had so far been recorded for that year. Although the rate of tanker crashes may seem low, the impact is usually severe. Most victims are killed by fire outbreaks and explosions, and most crashes involving tankers occur on highways and roads close to farm tanks and depots. 
Aside from tanker crashes, commercial motorcycle (popularly called okada) accidents were frequent in states that still permitted their operation. There were 216 motorcycle crashes reported between June 2006 and May 2014, including 25 in 2006, 41 in 2007, 32 in 2008, 18 in 2009, 14 in 2010, 27 in 2011, 17 in 2012, and 25 in 2013. Most motorcycle accidents occur in slum areas with less access to good roads and affordable cars. The severity index of motorcycle accidents is often high due to poor safety measures by riders and passengers.

\section{Severity index of fatal road accidents in Nigeria (June 2006-May 2014)}

The intensity of fatal road accidents varies from state to state. After comparing the number of people killed with the number of fatal crashes, states are ranked by a low, medium, or high severity index (Table 1.1).

Table 1.1 Severity index of fatal road accidents, by state (June 2006-May 2014)

\begin{tabular}{lcl}
\hline Group & Rank & State \\
\hline A & Low & Ebonyi, Lagos \\
B & $\begin{array}{c}\text { Medium } \\
(3.00-5.99 \%)\end{array}$ & $\begin{array}{l}\text { FCT, Ekiti, Delta, Akwa Ibom, Plateau, Bauchi, Bayelsa, Kwara, } \\
\text { bra, Sokoto }\end{array}$ \\
& High & $\begin{array}{l}\text { Imo, Jigawa, Benue, Niger, Edo, Gombe, Borno, Ondo, Enugu, } \\
\text { Kano, Kaduna, Rivers, Zamfara, Kogi, Katsina, Kebbi, Adama- } \\
\text { wa, Yobe }\end{array}$ \\
\hline
\end{tabular}

Severity index $=$ number of people killed / number of fatal crashes

Ebonyi and Lagos states ranked low (0.00-2.99\%) in the severity index of fatal road accidents that occurred between June 2006 and May 2014. Ebonyi had a severity index of $2.4 \%$ from 51 deaths in 21 crashes, while Lagos had a low severity index of $2.5 \%$ from 1,590 deaths in 620 crashes. States that are ranked medium (3.00-5.99\%) include FCT (Abuja), Ekiti, Delta, Akwa Ibom, Plateau, Bauchi, Bayelsa, Kwara, Osun, Cross River, Taraba, Ogun, Abia, Nasarawa, Oyo, Anambra, and Sokoto. Those ranked with a high index (6.00-8.99\%) are Imo, Jigawa, Benue, Niger, Edo, Gombe, Borno, Ondo, Enugu, Kano, Kaduna, Rivers, Zamfara, Kogi, Katsina, Kebbi, Adamawa, and Yobe. Highest in this category is Yobe State, with a severity index of $11.4 \%$. 


\section{Monthly analysis of fatal road accidents in Nigeria (June 2006-May 2014)}

Festive periods and environmental factors are major contributors to fatal car accidents in Nigeria. Hence, some months are regarded as more dangerous than others. Table 1.2 presents the monthly analyses of fatal car accidents in Nigeria within the period under study.

Table 1.2 Number of violent deaths in Nigeria caused by road accidents, per month (June 2006-May 2014)

\begin{tabular}{lrrrrrrrrrr}
\hline Month & 2006 & 2007 & 2008 & 2009 & 2010 & 2011 & 2012 & 2013 & 2014 & Total \\
\hline January & $\mathrm{n} / \mathrm{a}$ & 135 & 184 & 85 & 183 & 130 & 117 & 121 & 190 & 1,141 \\
February & $\mathrm{n} / \mathrm{a}$ & 150 & 168 & 97 & 152 & 193 & 181 & 143 & 200 & 1,284 \\
March & $\mathrm{n} / \mathrm{a}$ & 203 & 142 & 148 & 327 & 160 & 197 & 101 & 294 & 1,572 \\
April & $\mathrm{n} / \mathrm{a}$ & 118 & 101 & 180 & 160 & 129 & 131 & 346 & 127 & 1,292 \\
May & $\mathrm{n} / \mathrm{a}$ & 107 & 258 & 210 & 131 & 119 & 86 & 116 & 153 & 1,180 \\
June & 66 & 152 & 66 & 90 & 154 & 133 & 39 & 96 & $\mathrm{n} / \mathrm{a}$ & 796 \\
July & 258 & 62 & 193 & 113 & 232 & 149 & 282 & 174 & $\mathrm{n} / \mathrm{a}$ & 1,463 \\
August & 110 & 120 & 158 & 111 & 171 & 146 & 158 & 182 & $\mathrm{n} / \mathrm{a}$ & 1,156 \\
September & 200 & 198 & 161 & 174 & 95 & 126 & 147 & 185 & $\mathrm{n} / \mathrm{a}$ & 1,286 \\
October & 104 & 145 & 72 & 187 & 104 & 167 & 90 & 162 & $\mathrm{n} / \mathrm{a}$ & 1,031 \\
November & 173 & 112 & 150 & 59 & 108 & 286 & 78 & 164 & $\mathrm{n} / \mathrm{a}$ & 1,130 \\
December & 251 & 300 & 224 & 275 & 188 & 101 & 146 & 270 & $\mathrm{n} / \mathrm{a}$ & 1,754 \\
& & & & & & & & & & \\
Total & 1161 & 1802 & 1877 & 1729 & 2004 & 1839 & 1652 & 2061 & 964 & 15,090 \\
\hline
\end{tabular}

In order of decreasing number, 1,754 deaths occurred in the month of December; 1,572 in March; 1,463 in July; and 1,292 in April. These results show that fatal accidents happen more often during festive and seasonal periods. Christians celebrate Christmas in December and Easter in April or March. Within these periods, people travel to celebrate with their loved ones. According to Tumes Sylvanus Dalop, accidents and deaths are higher during these 'EMBER' months because of the various festivities lined up during this period, which involve much more travelling than usual. ${ }^{32}$ This is a period when commercial drivers make more money through overloading and excessive speeding, among other factors.

In 2013, for instance, December recorded the second-highest number of deaths, with 270 deaths in 76 incidents. The period was marked by various economic activities, including transportation of cattle from the North to the South. Approximately nine persons died in an auto crash that involved two articulated 32 Vanguard 2012 interview with the past Sector Commander of the FRSC, Mr. Tumes Sylvanus Dalop,
on EMBER months of road traffic accidents 
vehicles carrying passengers and cows. ${ }^{33}$ The traffic pressure on the road during the seasonal period increased fatal car accidents. Evading bad portions of the road led to fatal car accidents nationwide. In Sokoto, ten people died in an auto crash involving two J5 mini-buses. One of the vehicles had attempted to dodge pot-holes and the driver suddenly lost control. ${ }^{34}$ Another incident happened in November 2013 along the Lagos-Ibadan Expressway, where a multiple accident claimed 23 lives. ${ }^{35}$ The crash occurred when a tanker loaded with petrol lost control and rammed into trailers parked by the roadside, igniting an inferno that burnt other vehicles trapped in the pile-up.

Similar conditions apply to the Easter period. On 3 April 2013, for instance, 70 people died after a double-decker bus, a haulage truck, and a petrol tanker collided along the Benin-Ore Expressway. The tanker exploded and killed most people on board the bus. ${ }^{36}$ Two days later, a multiple accident involving a Dangote cement-laden trailer, a tanker, and a luxury bus led to the death of 60 persons in Edo. The bus lost control and rammed into the trailer and the trailer into the tanker. The victims were burnt beyond recognition. Approximately ten motorcycles and 15 shops were destroyed by the fire. ${ }^{37}$ On the same day in Anambra, another multiple accident involving a trailer, two mini-buses belonging to the Rivers State Transport Company (RSTC), and two other vehicles claimed 25 lives. ${ }^{38}$ Within a space of two days, 155 lives were lost on the road.

Finally, a total of 1,463 persons died in fatal road accidents in the month of July between June 2006 and May 2014. July is the peak of the rainy season, when road markings are less visible, bridges collapse, trees fall, and rivers flood.

\section{Daily analysis of fatal road accidents in Nigeria (June 2006-May 2014)}

Figure 1.4 shows that 2,468 people died in 481 crashes on Mondays from June 2006 to May 2014. This was followed by Sundays, with 2,425 deaths in 477 fatal road accidents, and Saturdays, with 2,269 deaths in 465 crashes. These results confirm the assumption that more accidents happen during weekends and Monday (when people return to work). Weekends are marked by several religious and social activities that lead to huge pressure on the roads and often lead to fatal accidents. Party activities, night clubbing, and other social events occur mostly during weekends. With limited driving experience, most youths engage in drunk

\footnotetext{
3 http://www.nigeriawatch.org/index.php?urlaction=evtView\&id_evt=12859\&rang=2

http://www.nigeriawatch.org/index.php?urlaction=evtView\&id_evt=12871\&rang=3

http://www.nigeriawatch.org/index.php?urlaction=evtView\&id_evt=12990\&rang=4

$\mathrm{http}: / /$ www.nigeriawatch.org/index.php?urlaction=evtView\&id_evt=11317\&rang=1

http://www.nigeriawatch.org/index.php?urlaction=evtView\&id_evt=11124\&rang=2

$38 \mathrm{http} / / /$ www.nigeriawatch.org/index.php?urlaction=evtView\&id_evt=12573\&rang=3
} 
driving, a situation that frequently leads to fatal road accidents. Smart et al. noted that limited driving experience, night-time driving, and fatigue are particular risks for young men. ${ }^{39}$ Using data from the University of Port Harcourt, Eke et al. found that $70 \%$ of fatal accidents in Port Harcourt occur during the weekends. ${ }^{40}$ People who travel back on Sundays to resume official duties on Mondays increase traffic volume and fatal road accidents. As for commercial drivers, they often try to recoup weekend expenses when they overload passengers and overspeed to complete more trips.

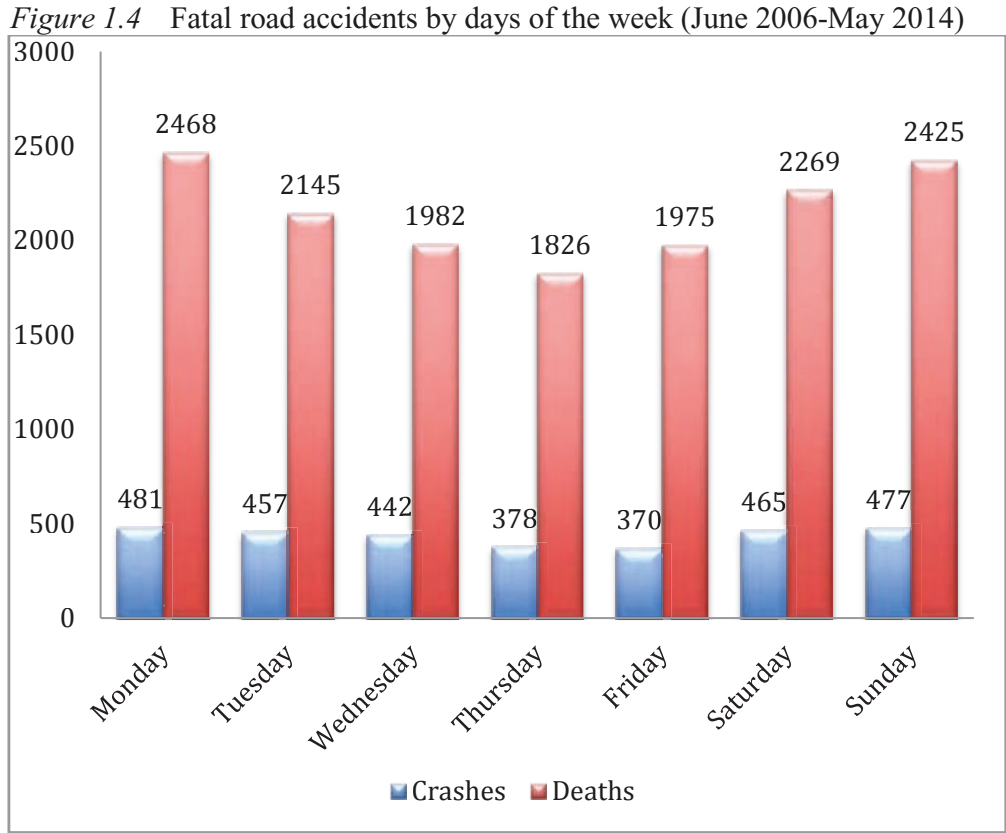

\section{State analysis of fatal road accidents in Nigeria (June 2006-May 2014)}

Although fatal car accidents are a nationwide calamity, the frequency and intensity varies from state to state. This section analyses the trends in fatal car accidents by state (Figure 1.6 and Table 1.3).

39 Smart, D., S. Vassallo, A. Sanson, S. Cockfield, A. Harris, W. Harrison \& A. McIntyre (2005), In: The Driver's Seat: Understanding Young Adults' Driving Behaviour. Melbourne: Australian Institute of Family Studies.

40 Eke, N., E.N. Etebu \& S.O. Nwosu (2000), Road Traffic Accident Mortalities in Port Harcourt, Nigeria. Anil Aggrawals Internet J. Forensic Med. Toxicol. 1(2). 
Figure 1.5 Number of violent deaths in Nigeria caused by road accidents, by state (June 2006-May 2014)

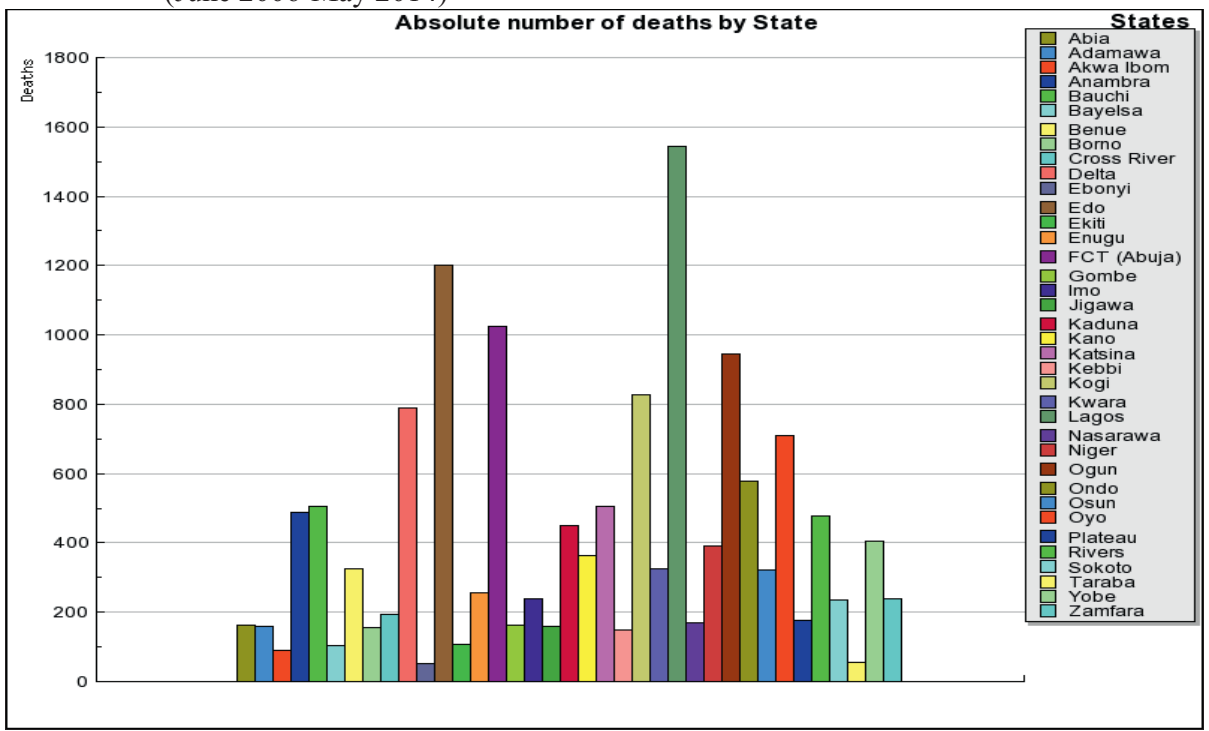

Data collected by Nigeria Watch show that Lagos has the highest number of fatalities on the national level with 1,579, followed by Edo with 1,129 deaths, and by FCT (Abuja) with 1,046 deaths. On the other hand, Ebonyi (51 deaths), Taraba (68 deaths), and Akwa Ibom (91 deaths) recorded far fewer fatal road accidents.

\section{Lagos State}

The number of Lagos residents is contested. According to the 2006 census, its population stands at 9,013,534, contrary to the state government's parallel count of 17.5 million. ${ }^{41}$ A recent World Bank demographic trend analysis reported that the Lagos State population growth rate of $8 \%$ has resulted in its capturing $36.8 \%$ of Nigeria's urban population, which is estimated to reach 49.8 million people. ${ }^{42}$ In this context, fatal car accidents are a challenge, with 212 deaths reported in six months in 2006; 260 in 2007; and 306 in 2008. However, there was a large reduction in road accident fatality rates, with 156 and 68 deaths in 2011 and 2012, respectively. The figure went up again in 2013, with 119 deaths, but was moderate in the first five months of 2014 (Table 1.3).

\footnotetext{
${ }^{41}$ http://www.lagosstate.gov.ng/pagelinks.php?p=6

$42 \mathrm{http}: / / w w w . l a g o s s t a t e . g o v . n g /$ pagelinks.php? $\mathrm{p}=6$
} 
Table 1.3 Yearly breakdown of road accident deaths in Nigeria (June 2006-May 2014)

\begin{tabular}{|c|c|c|c|c|c|c|c|c|c|c|}
\hline State & 2006 & 2007 & 2008 & 2009 & 2010 & 2011 & 2012 & 2013 & 2014 & TOTAL \\
\hline Abia & 0 & 28 & 12 & 3 & 1 & 5 & 57 & 42 & 5 & 153 \\
\hline Adamawa & 0 & 0 & 54 & 10 & 39 & 13 & 30 & 12 & 2 & 160 \\
\hline Akwa Ibom & 3 & 17 & 0 & 3 & 5 & 8 & 26 & 22 & 7 & 91 \\
\hline Anambra & 36 & 22 & 30 & 78 & 98 & 35 & 69 & 96 & 28 & 492 \\
\hline Bauchi & 23 & 17 & 69 & 24 & 65 & 124 & 88 & 76 & 19 & 505 \\
\hline Bayelsa & 1 & 30 & 19 & 4 & 0 & 3 & 3 & 34 & 10 & 104 \\
\hline Benue & 19 & 51 & 12 & 66 & 18 & 68 & 40 & 48 & 4 & 326 \\
\hline Borno & 0 & 21 & 13 & 45 & 17 & 12 & 18 & 18 & 11 & 155 \\
\hline Cross River & 34 & 21 & 54 & 10 & 10 & 10 & 6 & 26 & 18 & 189 \\
\hline Delta & 44 & 82 & 181 & 39 & 184 & 44 & 62 & 112 & 50 & 798 \\
\hline Ebonyi & 2 & 3 & 5 & 4 & 5 & 1 & 3 & 21 & 7 & 51 \\
\hline Edo & 47 & 88 & 164 & 196 & 11 & 208 & 85 & 210 & 120 & 1,129 \\
\hline Ekiti & 0 & 20 & 11 & 4 & 8 & 8 & 24 & 21 & 11 & 107 \\
\hline Enugu & 0 & 5 & 2 & 40 & 61 & 44 & 27 & 35 & 30 & 244 \\
\hline FCT & 48 & 80 & 159 & 120 & 198 & 134 & 87 & 162 & 58 & 1,046 \\
\hline Gombe & 20 & 15 & 19 & 24 & 40 & 27 & 5 & 23 & 0 & 173 \\
\hline Imo & 26 & 21 & 71 & 33 & 17 & 14 & 20 & 30 & 7 & 239 \\
\hline Jigawa & 1 & 24 & 23 & 14 & 6 & 10 & 13 & 32 & 37 & 160 \\
\hline Kaduna & 43 & 186 & 24 & 32 & 28 & 17 & 48 & 50 & 18 & 446 \\
\hline Kano & 36 & 16 & 31 & 102 & 49 & 48 & 13 & 50 & 28 & 373 \\
\hline Katsina & 36 & 80 & 8 & 64 & 52 & 121 & 50 & 83 & 10 & 504 \\
\hline Kebbi & 11 & 0 & 1 & 10 & 36 & 38 & 3 & 43 & 7 & 149 \\
\hline Kogi & 33 & 70 & 58 & 208 & 172 & 89 & 86 & 64 & 56 & 836 \\
\hline Kwara & 39 & 29 & 34 & 50 & 34 & 21 & 47 & 43 & 22 & 319 \\
\hline Lagos & 212 & 260 & 306 & 148 & 236 & 156 & 68 & 119 & 74 & 1,579 \\
\hline Nasarawa & 4 & 64 & 12 & 29 & 2 & 7 & 10 & 19 & 20 & 167 \\
\hline Niger & 21 & 18 & 40 & 37 & 94 & 70 & 13 & 51 & 48 & 392 \\
\hline Ogun & 82 & 95 & 87 & 105 & 92 & 86 & 227 & 182 & 28 & 984 \\
\hline Ondo & 67 & 81 & 59 & 34 & 148 & 106 & 53 & 20 & 15 & 583 \\
\hline Osun & 13 & 88 & 75 & 14 & 9 & 27 & 29 & 28 & 27 & 310 \\
\hline Оуо & 177 & 23 & 41 & 77 & 59 & 114 & 67 & 107 & 53 & 718 \\
\hline Plateau & 4 & 9 & 31 & 33 & 18 & 32 & 10 & 40 & 0 & 177 \\
\hline Rivers & 43 & 97 & 51 & 11 & 55 & 15 & 174 & 30 & 0 & 476 \\
\hline Sokoto & 8 & 44 & 38 & 12 & 46 & 8 & 28 & 19 & 32 & 235 \\
\hline Taraba & 5 & 9 & 20 & 11 & 5 & 1 & 5 & 6 & 6 & 68 \\
\hline Yobe & 6 & 36 & 38 & 13 & 62 & 88 & 40 & 50 & 78 & 411 \\
\hline Zamfara & 17 & 52 & 25 & 22 & 24 & 27 & 18 & 37 & 18 & 240 \\
\hline Total & 1,161 & 1,802 & 1,877 & 1,729 & 2,004 & 1,839 & 1,652 & 2,061 & 964 & 15,090 \\
\hline
\end{tabular}

Ikeja, the capital of Lagos State, recorded the highest number of deaths from car accidents. Most lives were lost in the Ikeja axis of the Lagos-Ibadan Expressway (Table 1.4). The strategic location of the area places it at the centre of fatal car accidents, with a record of 266 car accident deaths. Another route that has claimed many lives is the ever-busy Oshodi-Apapa Expressway. Oshodi is one of the most populated areas of Lagos State, with major industries located in 
the LGA. Within the period under study, 180 persons died in fatal car accidents. The expressway is a major link to Tin Island, where most companies involved in oil distribution are located. The presence of these companies has kept Apapa, Mainland, Island, and Eti-Osa continuously busy with commercial activities. Oil pipelines cut through many residential areas in Lagos State. Distribution of PMS, a major cause of deaths along Apapa/Mile 2/Oshodi Expressway, has always been ongoing. The volatility of such refined products makes it fatal each time tankers have accidents. In May 2008, for instance, an explosion occurred after a bulldozer hit an oil pipe and approximately 100 people were killed by fire, including many school children. ${ }^{43}$ Aside from oil companies, other protagonists, such as government security agencies, have caused fatal road accidents in the state. In a bid to evade harassment by the police, commercial bus drivers cause fatal accidents. In addition, the police mount road blocks that have caused several fatal road accidents. Approximately 54 people died in October 2010 in a multiple road accident caused by a police checkpoint on Shangisha Bridge, between the Toll Gate and Berger Bus Stop near Otedola Housing Estate. ${ }^{44}$

Table 1.4 Summary of fatal car accidents in Lagos, by LGA and route (June 2006-May 2014)

\begin{tabular}{lcl}
\hline LGA & No. of deaths & Most dangerous routes \\
\hline Amuwo/Odofin & 9 & Satellite Town \\
Epe & 49 & Lekki-Epe Road; Epe/Ibeju Expressway \\
Ibeju/Lekki & 49 & Lekki/Epe \\
Ifako-Ijaye & 28 & Abeokuta Expressway \\
Kosofe & 48 & Lagos-Ibadan Expressway; Ketu, Mile 12 \\
Mushin & 28 & Agege Motor Road; Ladipo \\
Ojo & 58 & Lagos-Badagry Expressway \\
Shomolu & 41 & Ikorodu Road; Gbagada Expressway \\
Lagos Mainland & 29 & Third Mainland Bridge \\
Lagos Island & 44 & Obalende \\
Ikorodu & 148 & Ikorodu Expressway \\
Surulere & 55 & Apapa-Oshodi Expressway; Ojuelegba \\
Oshodi-Isolo & 180 & Oshodi-Apapa Expressway \\
Ikeja & 266 & Lagos-Ibadan Expressway \\
Eti-Osa & 62 & Lagos-Epe Expressway \\
Badagry & 143 & Badagry Expressway; Eko Bridge \\
Apapa & 72 & Apapa-Oshodi Expressway; Tin Can Island \\
Alimosho & 150 & Igando Road; Lagos-Abeokuta Expressway \\
Agege & 97 & Lagos-Abeokuta Expressway \\
Ajeromi-Ifelodun & 23 & Ajegunle \\
& & \\
Total & 1,579 & \\
\hline
\end{tabular}

${ }^{43}$ http://www.nigeriawatch.org/index.php?urlaction=evtView\&id_evt $=3502 \&$ rang=1
44 http://www.nigeriawatch.org/index.php?urlaction=evtView\&id_evt=6634\&rang=2 
However, the administration of Governor Fashola (2007-2015) has achieved reasonable success in the reduction of road accidents in Lagos State. Lagos State Traffic Management Authority (LASTMA) was created to reduce deaths, injuries, and economic losses from road accidents by employing modern traffic management techniques. The agency is empowered, among other things, to relocate tankers to industrial parks, impound tankers and cars parked indiscriminately, and ensure strict compliance with safety measures.

\section{Edo State}

Edo State recorded the second-highest rate of fatal road accidents in Nigeria between June 2006 and May 2014, with 1,129 deaths in 177 accidents. There were 210 deaths in 2013; 208 in 2007; 196 in 2009; 164 in 2008; and 120 between January and May 2014. The strategic nature and location of Edo State as a major link to the South West, South-South, South East, and North Central place it on a list of states with a high risk of fatal car accidents. The state also serves as a major terminal to most drivers travelling to different parts of the country. Table 1.5 shows the distribution of fatal car accidents in Edo State within the period under study.

Table 1.5 Summary of fatal car accidents in Edo, by LGA and route (June 2006-May 2014)

\begin{tabular}{|l|c|l|}
\hline LGA & No. of deaths & Most dangerous routes \\
\hline Akoko-Edo & 46 & Okene-Abuja Expressway \\
\hline Egor & 1 & Benin-Ore Road \\
\hline Esan Central & 12 & Benin-Okene Highway \\
\hline $\begin{array}{l}\text { Esan North- } \\
\text { East }\end{array}$ & 10 & Irrua Benin Road \\
\hline $\begin{array}{l}\text { Esan South- } \\
\text { East }\end{array}$ & 1 & Iruekpen Road \\
\hline Esan West & 20 & Benin-Auchi Road \\
\hline Etsako East & 19 & Benin-Auchi Road \\
\hline Etsako West & 24 & Ekpoma Road \\
\hline Iguegben & 4 & Benin-Auchi Road \\
\hline Ikpoba-Okha & 23 & Benin-Oluku By-Pass \\
\hline Oredo & 419 & Benin-Ore-Lagos Road \\
\hline Orhionmwon & 33 & $\begin{array}{l}\text { Benin-Lagos Expressway; Benin-Auchi Road; Benin- } \\
\text { Asaba Road }\end{array}$ \\
\hline $\begin{array}{l}\text { Ovia North- } \\
\text { East }\end{array}$ & 176 & Benin-Ore Road \\
\hline $\begin{array}{l}\text { Ovia South- } \\
\text { West }\end{array}$ & 286 & Benin-Lagos Expressway \\
\hline Owan-East & 5 & Ora-Ihievbe-Warrake Road \\
\hline Uhunmwonde & 50 & Benin-Asaba Expressway \\
\hline \multicolumn{1}{|c|}{ TOTAL } & 1,129 & \\
\hline
\end{tabular}


Oredo LGA recorded 419 deaths from 83 crashes; Ovia South-West had 286 deaths from 20 crashes; and Ovia North-East had 176 deaths from 24 crashes. Benin-Ore Expressway remains the most dangerous route in the state. In April 2013, for instance, an accident that involved a cement-laden Dangote trailer, a tanker, and a luxury bus along the route led to the death of 60 persons. ${ }^{45}$ The bus, after bursting a tyre, rammed into the trailer, which in turn rammed into the tanker, and the 60 victims were burnt beyond recognition within minutes. Approximately ten motorcycles, 16 vehicles, and 15 shops by the roadside were also destroyed by the fire.

Another dangerous route in Edo State is the Benin-Auchi-Okene Highway. This route connects the state with Kogi and serves as a major route for persons travelling to the South West. The traffic volume on the road makes it the secondmost dangerous route within the period under study. In 2009, for instance, an 18seater bus collided with an oncoming trailer along the highway and killed 15 people. ${ }^{46}$ However, the recent reconstruction of some roads in the state by the Federal Government is expected to be a form of palliative measure to reduce the incidence of fatal car accidents in the state.

\section{FCT (Abuja)}

Table 1.6 shows the distribution of fatal road accidents in FCT. FCT recorded the third-highest death toll, with 1,046 lives in 348 fatal road accidents between June 2006 and May 2014, most of which occurred along the Abuja-Kubwa and AbujaLokoja routes and within the urban settlements. ${ }^{47}$ Abuja Municipal recorded the highest number of fatal car accidents in the period under review, with 344 deaths, followed by Kwali with 248 deaths and Abaji with 212. While road accidents are widely distributed in FCT (Abuja), the municipal area accounted for $34 \%$ of the total road accident fatalities in the state, followed by Kwali (23\%), Abaji (21\%), and Gwagwalada (18\%). Roads in Kuje were very peaceful, with just one death in one incident within the period under study.

Reasons for the high rate of fatal accidents in FCT (Abuja) can be narrowed down to the good state of roads and the number of registered cars in Abuja. The Abuja-Kubwa-Zuba route, awarded for construction in 2012 by the Federal Government of Nigeria, is the best and widest in the country, with ten lanes. Motorists, however, are ignorant of the dangers associated with smooth roads and have little consideration for safety measures. There is so much confidence among road users that the slightest brush leads to altercations and tailgating. Secondly, there

$45 \mathrm{http} / / /$ www.nigeriawatch.org/index.php?urlaction=evtView\&id_evt=11124\&rang=1

$46 \mathrm{http}: / /$ www.nigeriawatch.org/index.php?urlaction=evtView\&id_evt=5153\&rang=1

47 The breakdown of Table 1.6. gives a lower number of fatalities $(1,026)$ because the figures reported for some accidents were rounded up. 
has been a large increase in the number of vehicles plying the roads in the city, with consequent traffic chaos. Understandably, this led to a ban on the use of mini-buses for commercial purposes and the restriction of motorcycles and tricycles to the outskirts of the city. ${ }^{48}$

Table 1.6 Summary of fatal car accidents in FCT (Abuja), by LGA and route (June 2006-May 2014)

\begin{tabular}{lcl}
\hline LGAs & No. of deaths & Most dangerous routes \\
\hline Abaji & 212 & Abuja-Lokoja Highway \\
Abuja Municipal & 344 & Abuja-Kubwa-Zuba, Airport Road; Abuja-Nyanya-Keffi \\
Bwari & 39 & Abuja-Zuba Expressway \\
Gwagwalada & 182 & Abuja-Lugbe-Gwagwalada Road; Abuja-Lokoja Highway \\
Kuje & 1 & Kuje Expressway \\
Kwali & 248 & Abuja-Lokoja Highway (Yangoji) \\
& & \\
Total & 1,026 & \\
\hline
\end{tabular}

\section{Analysis of fatal road accidents in Nigeria by region and geo-political zone}

Nigeria is broadly divided into North and South. The North is comprised of Kogi, Niger, Benue, Kwara, Plateau, Nassarawa, FCT, Taraba, Borno, Bauchi, Adamawa, Gombe, Yobe, Kaduna, Kebbi, Zamfara, Sokoto, Kano, Jigawa, and Katsina states. The South comprises Ebonyi, Enugu, Imo, Abia, Anambra, Akwa Ibom, Bayelsa, Edo, Cross River, Rivers, and Delta states. Others are Oyo, Ogun, Lagos, Ondo, and Osun states.

Based on the 2006 census, the nation's population is 140 million. Kano is the most populated state in the North, with 9,383,682 inhabitants, while FCT (Abuja) has the lowest population, with 1,405,201. The population of southern Nigeria is dominated by Lagos $(9,031,534)$, while Bayelsa is the least populated state, with $1,703,358$.

Results in Figure 1.6 show that 8,288 (55\%) of people who died in fatal road accidents were in the South and 6,792 (45\%) were in the North. ${ }^{49}$ In the South, many people died on the Lagos-Ibadan, Benin-Ore, and Enugu-Port Harcourt expressways prior to recent renovations. In the North, FCT (Abuja) has one of the best road networks in the country. Yet good roads also entail over-speeding and a high risk of fatal accidents. The number of registered vehicles also determines the frequency of fatal road accidents. According to the NBS, in 2007 a

\footnotetext{
48 http://www.dailytrust.com.ng/daily/city-news/30374-abuja-a-city-of-good-roads-several-accidents

49 The figures reported for some accidents were rounded up.
} 
total of $387,338(76 \%)$ of all vehicles were registered in the South and 122,804 $(24 \%)$ in the North (Figure 1.7).

Figure 1.6 Number of violent deaths in Nigeria caused by road accidents, by region (June 2006-May 2014)

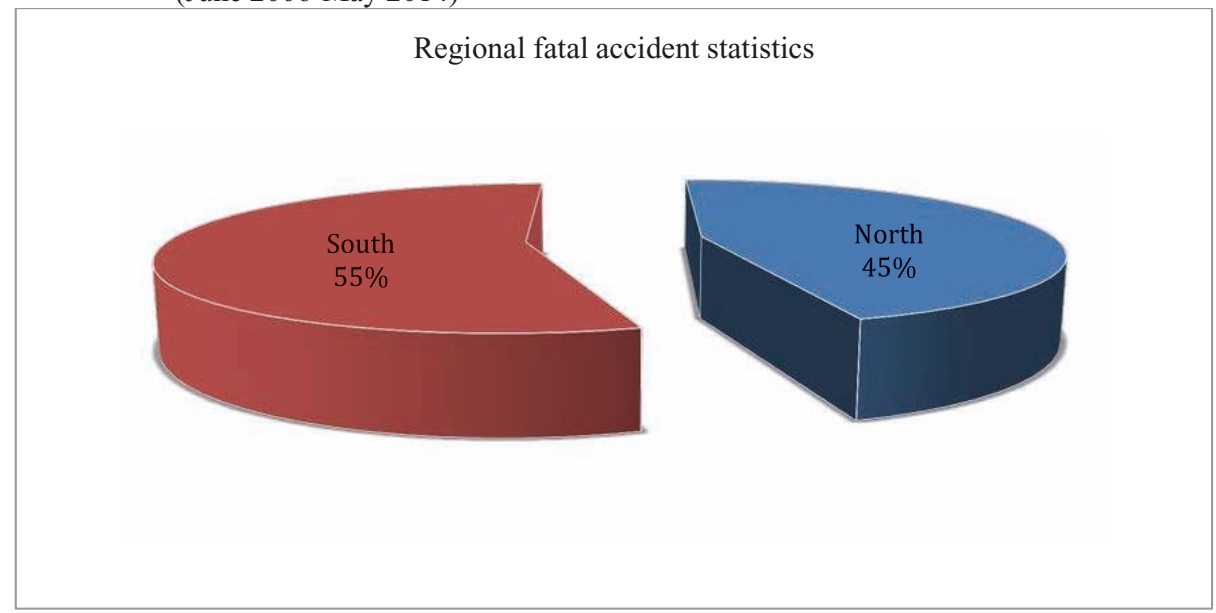

Figure 1.7 Number of motor vehicles registered in Nigeria (2007)

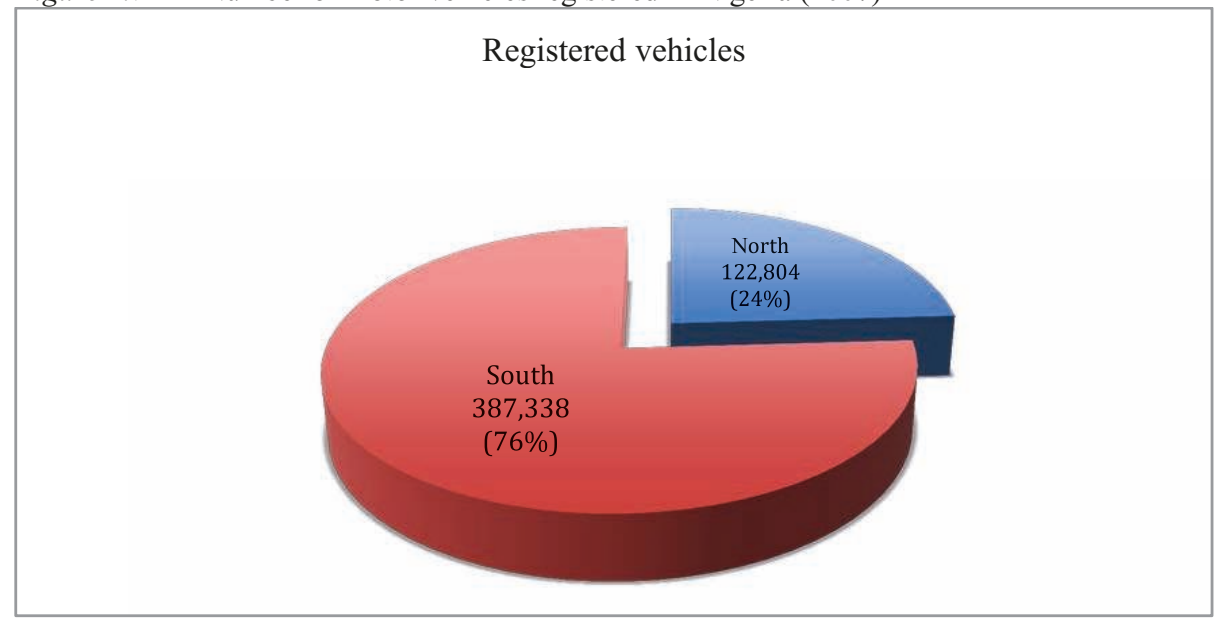

Source: National Bureau of Statistics (2009); Annual Abstract of Statistics (2009)

Oil distribution by tankers is also an important factor in the incidence of road accidents in the South. Tankers are usually rocked by fire explosions when they crash on the roads. Several commuters have lost their lives in such incidents, es- 
pecially along the Lagos-Sagamu-Ibadan Expressway, the East-West Road in Rivers State, and the Benin-Ore route in Edo. The failure of the government to renovate the railway system has led to increased pressure on oil distribution companies to use road transportation.

Furthermore, rampant criminal activities on the expressways have caused several fatal road accidents in the South. The South is home to different networks of criminal gangs, and motorists are both robbed and forced to lie on the tarred roads, only to be crushed by oncoming vehicles. In some cases, they are chased into fatal accidents. On 1 August 2008, 30 Igbo traders were robbed in Ijebu Ode along the Benin-Ore Expressway. They were forced to lie face down on the road and eventually were crushed to death by an oncoming trailer. ${ }^{50}$ Similarly, 32 bus passengers were victims of a robbery, during which they were forced to lie on the road and were crushed to death by an oncoming luxury bus. ${ }^{51}$ Such fundamental and structural issues in the South have always made the North a safer area with respect to the number of fatal car accidents in Nigeria.

When death figures from road accidents in the six geo-political zones of Nigeria are compared, South-West recorded the greatest number of deaths $(4,239)$ and was followed by North Central $(3,242)$. This result is unsurprising given the immense contribution of Lagos and Oyo states (South West) and FCT (Abuja) and Kogi states (North Central) to fatal road accidents.

\section{Population, rural-urban migration and fatal road accidents in Nigeria}

Urbanization has taken a huge toll on the population in Nigeria in terms of fatal road accidents. The nation is one of the countries in the developing world with a high rate of rural-urban migration and fast-growing cities. Although growth is a global phenomenon, $90 \%$ of growth in urban population worldwide occurs in developing countries and places intense pressure on urban infrastructure, particularly transportation. ${ }^{52}$ In this context, very large metropolitan areas like Lagos, Kano, Ibadan, Kaduna, and Port Harcourt face congestion problems that often occur when traffic pressure is increased in the transport systems. A high number of accidents happen owing to the general impatience and ill-tempered nature of road users and to conflicts between pedestrians and those using other means of road transport in the cities. ${ }^{53}$

\footnotetext{
$50 \mathrm{http}: / /$ www.nigeriawatch.org/index.php?urlaction=evtView\&id_evt=5121\&rang=4

51 http://www.nigeriawatch.org/index.php?urlaction=evtView\&id_evt=8168\&rang=10

52 Rodrigure, J. (2009), The Geography of Transport Systems, 2nd edition. New York: Routledge.

53 Ogunsanya, A.A. (1993), Directions in Urban Transport Studies in Nigeria. In: Ikya, S.G., ed.,. Urban Passenger Transportation in Nigeria, Heinemann Educational Books (Nig.) Plc.
} 
Table 1.7 Population of main cities and number of deaths caused by road accidents (June 2006-May 2014)

\begin{tabular}{lcc}
\hline City & City population & $\begin{array}{c}\text { No. of deaths caused by road } \\
\text { accidents }\end{array}$ \\
\hline Lagos & $8,029,200$ & 1,579 \\
Kano & $3,248,700$ & 373 \\
Ibadan & $3,078,400$ & 718 \\
Kaduna & $1,458,900$ & 446 \\
Port Harcourt & $1,053,900$ & 476 \\
\hline
\end{tabular}

Source: National Population Commission, 2006; Nigeria Watch, 2006-2014

Lagos, the most populous city in Nigeria, is the second-fastest-growing city in Africa and the seventh in the world. ${ }^{54}$ Rural-urban migration, immigration, unemployment, inadequate social amenities, and the lack of urban planning explain infrastructural decay, including the poor road transportation system, and account for the 1,579 road accident deaths between June 2006 and May 2014. By contrast, Kano is much less affected by such accidents because its inhabitants are relatively poor and there are fewer cars on the road (Table 1.7).

In order of importance, Ibadan, capital city of Oyo State, is the third-largest metropolitan area in Nigeria, after Lagos and Kano. It recorded the secondhighest number of car accident deaths (718) within the period under study. Ibadan, mostly seen as the centre of administration of the old Western Region, consistently witnesses massive rural-urban migration from neighbouring communities. The state has a network of dual-carriageway roads, including the OjooSango-Mokola Road, the Ring Road-Orita-Challenge-New Garage route, and the recently completed Dugbe-Eleyele-erico Road. Most of the accident deaths that occurred within the city were on these roads.

Port Harcourt, another major city in Nigeria, recorded 476 road accidents fatalities between June 2006 and May 2014. The city is an epicentre of the oilrelated activities of a large number of multi-national and local firms. Hence, oil distribution has been a major threat to the city, when one considers the effects of tanker accidents, explosions, and fire outbreaks. Aside from oil-related activities, Port Harcourt is known for its bustling night activity and entertainment industry. Late-night driving, under-age driving, and drunk driving are factors that have all contributed to the number of fatal road accidents in the state. Finally, the volume of trade within the city due to its proximity to Aba, the commercial centre of Abia State, increases the volume of traffic pressure from traders flocking in and out of the state. This high traffic volume often causes fatal road accidents.

54 World's Fastest Growing Cities and Urban Areas from 2006 to 2020, by CityMayors.com 


\section{Conclusion}

This study has examined the trends in road accidents in Nigeria between June 2006 and May 2014. After studying the causes of violent deaths in Nigeria from an overall point of view, fatal road accident was discovered to be the main cause of violent fatalities, apart from the Boko Haram insurgency. Different contexts precipitate fatal car accidents in Nigeria. Understanding these political and socioeconomic contexts provides a better insight into why road accident has remained a leading cause of death in the country. The distribution of fatal car accidents among the 36 states and the FCT shows that Lagos State recorded the highest number of fatal car accidents, but is less dangerous in terms of the calculated severity index. Abuja is more dangerous when compared with its relative number of inhabitants. Results further showed that regional variations exist in the fatality rates from road accidents, with more deaths occurring in the South than in the North. The results also established that state and city population estimates, number of registered vehicles, and trade volume are among the variables that determine the fatality rate of road accidents in Nigeria. Finally, it appears that road maintenance remains an issue because criminal gangs take advantage of bad spots on the highways to rob travellers, causing fatal car accidents in the process.

\section{References}

ABDalLa, I.M. (1997), Statistical Investigation and Modeling of the Relationships between Road Accidents And Social Characteristics. PhD Thesis, Napier University, Edinburgh.

AdeKunle, J.A. (2010), Road Traffic Accident Deaths and Socio-Economic Development in Nigeria. International Review of Business and Social Sciences 1(5): 47-60.

AdERAMO, A.J. (2002), Transport and the Nigerian Urban Environment. Paper delivered at 45th Annual Conference of the Nigerian Geographical Association, 30 June to 3 July, University of Ilorin, Nigeria.

Aderemo, A.J. (2012), Spatial Pattern of Road Accident Casualties in Nigeria, Mediterranean Journal of Social Sciences 3(2): 61-72.

Agbeboh, G.U. \& O. Osabuohien-Irabor (2013), Empirical Analysis of Road Traffic Accidents: A Case Study of Kogi State, North-Central Nigeria. Department of Mathematics, Ambrose Alli University, Ekpoma, Nigeria.

Agbonkhese, O., G.L. Yisa, E.G. Agbonkhese, D.O. AKAnBi, E.O. AKa \& E.B. Mondigha (2013), Road Traffic Accidents in Nigeria: Causes and Preventive Measures. Civil and Environmental Research 3(13): 90-99.

Alhassan, U.B. (2013), Herdsmen and Farmers Conflicts in North-Eastern Nigeria: Causes, Repercussions and Resolutions. Academic Journal of Interdisciplinary Studies 2(5): 129139. Published by MCSER-CEMAS-Sapienza University of Rome.

Assum, T. (1998), Road Safety in Africa: An Appraisal of Road Safety Initiatives in Five African Countries. Terje Assum. Sub-Saharan Africa Transport Policy Program working paper series (SSATP), no. 33. Washington, DC: World Bank. 
http://documents.worldbank.org/curated/en/1998/02/2787020/road-safety-africa-appraisalroad-safety-initiatives-five-african-countries. Accessed 18 August 2015.

Chen, G. (2010), Road Traffic Safety in African Countries: Status, Trend, Contributing Factors, Counter Measures and Challenges, International Journal of Injury Control and Safety Promotion 17(4): 247-255.

Christie, N. (1995), Social, Economic and Environmental Factors in Child Pedestrian Accidents: A Research Review. Transport Research Laboratory, Project Report 116.

Eke, N., E.N. EteBu \& S.O. Nwosu (2000), Road Traffic Accident Mortalities in Port Harcourt, Nigeria. Anil Aggrawal's Internet Journal of Forensic Medicine and Toxicology 1(2).

FEDERAL Ministry OF INFORMATION (2013), Road Accident Report.

Federal RoAd SAFETy COMMISSION (2010), Research Monograph No. 2, Road Mirror.

FEDERAl RoAd SAFETy CORPS (FRSC) (2007), An Article on the FRSC Establishment Act. www.frsc.gov.ng.

Federal RoAd SAFETy CORPS (FRSC) (2010), Report on Road Traffic Crashes (RTC) Involving Buses on Nigerian Roads (2007-2010).

HANCOCK, P.A., M. LeSCH \& L. Simmons (2003), The Distraction Effects of Phone Use During a Crucial Driving Maneuver. Accident Analysis and Prevention 35: 501-514

InTERNATIONAL RoAD TRAFFIC AND ACCIDENT DATABASE (IRTAD) (2007), Road User Fatalities. Paris: Directorate for Science, Technology and Industry. Organization for Economic Co-operation and Development (OECD).

Jacobs, G. \& A. Aeron-Thomas (2000), Africa Road Safety Review Final Report. Washington, DC: US Department of Transportation, Federal Highway Administration.

LAGARDE, E. (2007), Road Traffic Injury is an Escalating Burden in Africa and Deserves Proportionate Research Efforts. PLOS Medicine 4(6): 967-971.

NAtional Bureau of Statistics (2009), Annual Abstract Of Statistics.

NATiOnal BuREAu OF StAtistics (2010), The Review of the Nigerian Economy.

OGUNSANYA, A.A. (1993), Directions in Urban Transport Studies in Nigeria. In: S.G. Ikya, ed., Urban Passenger Transportation in Nigeria. Nigeria: Heinemann Educational Books.

PÉRouse DE MonTClos, M.-A. (2014), Nigeria Watch: Fourth Report on Violence in Nigeria (2006-2014). Institut français de géopolitique, Université Paris.

PRATTE, D. (1998), Road to Ruin: Road Traffic Accident in the Developing World, NEXUS 13: 46-62.

Rodrigure, J. (2009), The Geography of Transport Systems. 2nd ed. New York: Routledge.

SMART, D., S. VASSAllo, A. SANSON, S. COCKFIEld, A. HARris, W. HARrison \& A. MCINTYRE (2005), I: The Driver's Seat: Understanding Young Adults' Driving Behaviour. Melbourne: Australian Institute of Family Studies.

Sumaila, AbdulGaniyu Femi (2013), Road Crashes Trends and Safety Management in Nigeria. Department of Transport Management Technology, Federal University of Technology, Minna.

WHO (2004), World Report on Road Traffic Injury Prevention. Geneva: World Health Organization.

WHO (2011), Decade of Action for Road Safety (2011-2020), Global Launch. http://www.who.int/entity/roadsafety/publications/global_launch.pdf?ua=1. Accessed 18 August 2015. 


\title{
Patterns and trend analysis of violence in oil production and oil distribution in Nigeria (2006-2014)
}

\author{
Adeola Adams
}

\begin{abstract}
Most studies on oil-related violence in Nigeria have unwittingly concentrated research efforts on oil production in the Niger Delta region. An attempt is made in this paper to demonstrate that oil distribution contributes more to fatality in Nigeria than oil production. Using the Nigeria Watch database as the primary source of data, the paper asserts that although the aggregate death figures attributed to the oil sector are lower than cases like road accidents, crime, and politically-cum-religiously motivated killings, the number of violent deaths recorded between June 2006 and May 2014 in relation to oil distribution is triple the number related to oil production. While oil distribution accounted for 4,575 deaths, oil production events led to 1,550 deaths; therefore, oil distribution has a far more lethal impact on the country than oil distribution. Apart from Kebbi and Zamfara, all the states of the Nigerian Federation have witnessed at least one fatal incidence from oil distribution, whereas oil production cases occur mainly in Anambra, Rivers, Delta, Akwa Ibom, Bayelsa, and Imo. The reasons are not difficult to understand: oil production is restricted to a few states in the Niger Delta area, while oil distribution activities cover the whole nation. Moreover, oil production deals essentially with crude oil, which is less flammable than the highly inflammable refined products involved in oil distribution. In addition, oil distribution has a strong link with road accidents, which are rated as one of the main contributors to fatalities in Nigeria. In the final analysis, to understand the pattern and dynamics of fatalities in the oil sector, more research efforts need to be devoted to oil distribution.
\end{abstract}

\section{Introduction}

On 26 December 2006, a pipeline explosion at Abule-Egba in Agege LGA in Lagos claimed the lives of more than 600 persons. In a related development, a series of deadly clashes between the Joint Task Force (JTF) and militants in War- 
ri South and Warri South West LGAs in Delta State on 13 May 2009 culminated in the deaths of some 593 victims. Such volatile outcomes and lethal consequences are usually associated with oil-related violence in Nigeria. Although oil violence may not be the major cause of fatal incidents in the country, its occurrences, especially those that have to do with oil distribution, have continued to trigger violence of frightening proportions at various levels. Perhaps one important question to ask is why such an important sector is associated with fatal incidents of such magnitude? One reason is that Nigeria's economy relies heavily on crude oil, and hence it is only to be expected that commercial activities around oil become intense and highly competitive. In fact, most international businesses in the country are driven by the oil factor. The nation's oil has attracted a contested platform of intense power plays by forces within and without the state frontiers. According to Obi (2005: 187):

Oil as a source of power and wealth is central to Nigeria's federalism. It exerts a lot of influence by defining the object of power and by its dialectically being a source of wealth, poverty, unity, intense competition, and conflict. This manifests at the levels of oil production and distribution.

A second reason is found in the 'oil curse' thesis, which has been sufficiently appraised in the literature and still continues in a primitive economy like Nigeria's. The argument is that the rise in oil production and the inevitable oil boom have a tendency to precipitate socio-economic instability-and ultimately violence (Ikelegbe 2005). However, this amounts to an over-simplification of the problem, and it is necessary to probe beyond the oil curse theory and investigate the role of oil production and distribution in the complex matrix that makes violent incidents frequent. ${ }^{1}$ It is even more imperative considering the policy summersaults that the sector has witnessed in recent times. For instance, the Petroleum Industry Bill (PIB), which seeks to achieve a robust and comprehensive reform in the dwindling oil sector, has reached an advanced stage. The matter therefore calls for a deeper analysis of the issues to enable policy options at a scientific level to be potent enough to remedy the degenerating situation.

In retrospect, the oil industry has been a magnet for major stakeholders with various political and economic interests across the country. Although issues of politics, ethnicity, and religion are known to be volatile in Nigeria, oil-related violence also impacts significantly on the social environment. Previous analyses of oil conflicts in Nigeria have unduly concentrated research efforts on oil production within the locale of the Niger Delta (Ikporukpo 2002; Obi 2005; Ogbogbo 2005; Guichaoua 2009; Akpabio \& Akpan 2010). But as the main findings of this paper will suggest, the frequent movement of oil products to different parts

Pérouse de Montclos, M.-A. (2014), Oil Curse, State Instability, and Violence in Developing Countries: Theoretical Lessons for Nigeria, Ibadan, IFRA-Nigeria, epaper no. 33, 37 pp. 
of Nigeria on the country's dilapidated roads makes large numbers of fatalities likely. Fatalities associated with oil production are largely limited not only in terms of their concentration in the core oil-producing states in the Niger Delta (with a few cases in Kogi because of a border dispute with Anambra), but also in that we are dealing with a non-flammable product: crude oil. The inflammable nature of refined oil, on the other hand, and the poorly maintained tankers that often convey these products predispose oil distribution to causing large-scale violent fatalities.

The intention of this paper is to dissect the gamut of activities that account for the contours of violent incidents within the oil sector from 2006 to 2014, with a focus on oil production and oil distribution in Nigeria. The data for the paper is extracted from the Nigeria Watch database. The patterns of violent events that relate to oil distribution and production nationwide are illustrated with the aid of charts and maps to show important trends. In order to advance the central themes of this paper, two probing questions are instructive: Why is oil distribution more fatal than oil production in Nigeria? Why do stakeholders-authorities, NGOs, scholars, and security professionals-concentrate more on issues that involve oil production?

This paper has been carefully structured to provide adequate responses to these pertinent questions. This first section introduces the paper by presenting the general outline of the discussion. The next section takes a critical look at the political, economic, and social contexts of oil distribution and production, exploring their historical evolution since 1956 and their transformation after 2009. The third section discusses the methodological approach of the research and further addresses some specific issues that concern oil production and distribution. The fourth section presents the key findings, and the paper ends with a Conclusion.

\section{Political, economic and social context of oil distribution and production in Nigeria}

It is important to situate the subject of this paper within the political, social, and economic milieu of oil production and distribution in Nigeria. To achieve this, this section of the paper is divided into two sub-sections. The first attempts to explore the historical background to the oil industry in Nigeria. Here, the evolutionary trends since the colonial period, especially from 1956 when oil was first discovered in Olobiri, through the military era, when the major infrastructure of oil was established, are briefly discussed. The second sub-section covers issues that emerged in post-2009 oil governance in Nigeria. 


\section{Historical background since 1956}

Before Nigeria assumed its current 'petrostate' status, it had always operated as a purely agrarian economy. The abolition of the slave trade in 1807 led British colonial policy in West Africa to switch from trade in humans to appropriating territories for mass production of cash crops such as cocoa, coffee, cotton, and peanuts. In the Niger Delta region, which was then home to the Bonny, Brass, Kalabari, Itsekiri, and Aboh people, it was the booming oil palm business that attracted the colonialists to the area (Falola 2009). By 1886, the Royal Niger Company had successfully secured a charter from the British government to formally administer the area as a protectorate (the Oil Rivers Protectorate) of the British Crown. This charter empowered the company to govern and administer justice in the region in the manner it deemed fit, and it did not hesitate to use this machinery to consolidate its stronghold for maximum economic gains. These activities later ushered in a full-scale colonial government, which effectively imposed British foreign rule on the conquered territories in 1901. As the clamour for independence increased in the $20^{\text {th }}$ century, a unique dimension to the political economy of the colonial state emerged when crude oil was discovered in Olobiri by Shell-BP in 1956.

The first oil export was achieved in 1958, spurring the nation's economy to grow at a tremendous rate. By the early 1970s, revenue accruing from oil had become the main source of state income. The consequence was that the previous gains recorded in the agrarian sector suffered a serious setback, as attention was shifted principally to oil exploitation. According to Obi (2005), the discovery of crude oil in commercial quantities in Oloibiri in 1956 played an important role in the country's leap from a cash-crop-based to an oil-based economy. In the 1970s, the nation invested heavily in oil infrastructure through the construction of refineries, storage depots, and pipelines. Subsequently, refineries were built in Port Harcourt, Warri, and Kaduna, while storage depots were installed in Aba, Enugu, Ore, Yola, Satellite Town (Lagos), Makurdi, Ilorin, Suleja, Kano, Gombe, Gusau, Minna, Jos, and Mosimi to facilitate the processes of oil distribution (Eke \& Enibe 2007).

The tasks of oil production and distribution lie with both public and private business efforts. While the public agencies are represented by the Nigeria National Petroleum Corporation (NNPC) and its two subsidiaries, the Department Petroleum Resources (DPR) and the Petroleum Products Pricing Regulatory Authority (PPPRA), private investors include those referred to as Independent Marketers (IMs) and Major Oil Marketers (MOMs). The MOMs dominate the market and include Mobil Oil Nigeria Plc, Total Plc, MRS Nigeria Plc, Conoil Plc, African Petroleum Plc, and Oando Nigeria Plc. In fact, the concept of independent marketing appeared first in the lexicon of the oil industry in 1978 when there was 
a need to bring indigenous investors into the framework of the oil business. According to Edoreh (cited in Ehinimen \& Adeleke 2012), there were over 1,000 registered IMs in 1979, and by 2010 there were about 7,948 IMs operating in various locations across the country. The MOMs have also successfully established more than 2,218 outlets in various locations around the country. Despite this marked difference, however, the MOMs still manage to control well over $60 \%$ of the market.

Figure 2.1 Physical flow of products: Retail route used by Major and Independent Marketers in Nigeria

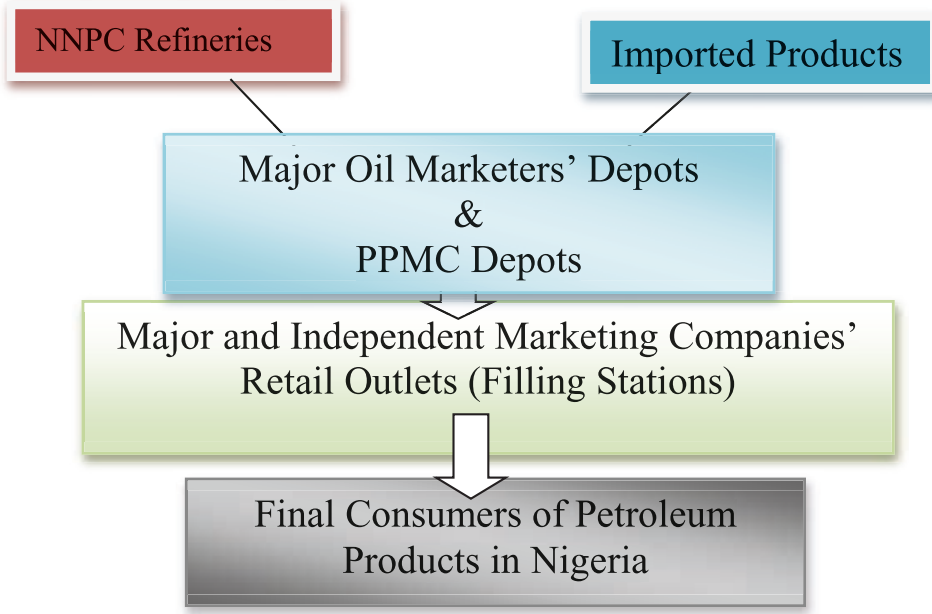

Courtesy of NNPC/PPMC Bulletin (cited in Ehinomen \& Adeleke 2012)

The distribution of petroleum products, which is the movement of refined petroleum from refineries to the final users across the country, is a crucial and at the same time a complex component of the production process (Figure 2.1). According to Nothingham (2004), the distribution component of the petroleum value chain holds the most promise for domestic initiatives. The Pipeline and Product Marketing Company (PPMC) is tasked with wholesale supply, distribution, and marketing of petroleum products in Nigeria. There is a complex network of over $4,000 \mathrm{~km}$ of pipelines connected to more than 21 oil depots across the country. There are also more than 20 marine tankers used to ferry heavy products from coastal refineries in Warri and Port Harcourt to places like Lagos, where there is a high demand. The situation has worsened in light of the fact that most of the pipelines suffer from leaks owing to lack of maintenance and, of course, the ac- 
tivities of vandals and thieves. This has left marketers with no other option but to resort to the use of tankers and trailers to transport the products. These practices have spelled doom for the booming sector.

Although the arrival of the oil economy significantly increased the revenue base of the state, it did not translate into a good life for the majority of the population. Citing Sala-i-Martin and Subranain's analysis of the inherent paradox of the oil wealth, Guichaoua (2009: 18) wrote:

In Nigeria, the GDP per capita in 2000 was roughly the same as in 1970. But the proportion of the population living on less than a dollar a day went from $36 \%$ to $70 \%$ over the same period. However, between 1965 and 2000, per capital oil revenue increased from $\$ 33$ to $\$ 325$. At the same time, income inequalities exploded. In 1970, the top 2\% of income earners made as much as the bottom 17\%; in 2000, the income of this top 2\% was equivalent to the income of the bottom 55\% combined.

According to Obi (2005), two main factors explain this unfortunate development. First, the partnership between the Nigerian state (through the NNPC) and oil multinationals is such that oil production in Nigeria since the 1970s is marred by distrust and high-level technical irregularities on the part of the oil companies. As the multinationals are solely responsible for the oil production processes, the actual volume of production has always been shrouded in secrecy. The Federal Government is basically a collector of oil rents but lacks the technical know-how to monitor and supervise oil production. Hence, the government merely relies on transnational corporations to determine the revenue accruing from oil production. This arrangement gives ample space for the government to be short-changed in this closed system of operation. Secondly, the distribution of oil wealth under the control of the ruling elites has further exacerbated the problem. Violent crises have erupted in many parts of the Niger Delta as a result of the sheer mismanagement and misallocation of oil proceeds. This argument is often situated within the oil curse discourse, which considers the discovery of petroleum to be associated with violence, corruption, abject poverty, and under-development (Ikpurukpo 2002).

The period of the oil boom also coincided with the militarization of politics. By virtue of their centralized command system, the various military regimes appropriated the resources of regions/states, including the oil in the Niger Delta, to strengthen their grip on political power and to perpetuate their anti-populist agendas. Consequently, the derivation principle ${ }^{2}$ suffered a severe setback as parochial greed assumed centre stage in government affairs. Emphases for the sharing of national resources were placed on equitable development, special needs,

\footnotetext{
'Derivation' is the notion of allocating a certain percentage of revenue amassed from oil and gas to the resource-producing states or region. It was ingrained in Nigeria's federal system prior to independence in 1960. However, the derivation formula had dropped from an initial $50 \%$ to as low as $1 \%$ in 1990 s, as a result of military autocracy. It is currently a $13 \%$ share of oil proceeds. Derivation also featured as the most controversial issue in both the 2005 and the 2014 constitutional conferences in Nigeria.
} 
and the population (Oputa Panel Report, cited in Ojakorotu \& Olawale 2009). Hence, the Niger Delta region became an arena of dangerous protests against the perceived marginalization arising from the imperfections of the nation's federal arrangement. This phenomenon has been described as 'the minority question' in Nigeria (Osaghae 1995). The painful effects of the military's imposed economic policies, the most famous of which was the Structural Adjustment Policy (SAP) that held sway in the 1980s, further ignited civil unrest among minorities and an array of civil society groups. Since the character of the military is to by-pass constitutional solutions and subvert the supremacy of the general will, it resorted to extra-judicial and violent means to press home legitimate demands by minority groups across the country (Osaghae 1998). The problem of oil exploration in the Niger Delta can also be understood in this context. Again, in Osaghae's (ibid. 13) opinion:

The militant character of the Ogoni uprising, the high proportion of officers from minority, especially Middle-Belt, groups in military coups, the resort to rioting rather than the court of law by many minorities in the north, and the increasing use of sabotage of strategic oil installations by aggrieved minorities of the oil areas, are to be explained in this light.

For Pérouse de Montclos (2012: 536):

[...] the struggle for regional control of oil resources is certainly political, as the militants advocate the so-called derivation principle and oppose the federal character of the Nigerian Republic, whereby richer states (in the South) are supposed to fund the poorer (in the Muslim North).

These protests, which usually played out on different platforms, including counter-military coups, led the military government to adopt two strategies to deal with the problem. First, there were some adjustments in government policies to soothe the aggrieved. For instance, the failed coup of Major Gideon Orkar in 1990 led not only to an increase in the derivation allocation to the oil-producing states from $1.5 \%$ to $3.0 \%$; it also led to the establishment of the (now defunct) Oil Minerals Producing Areas Development Commission (OMPADEC) in 1992 in order to ensure that the resources allocated to the areas were properly managed (Osaghae 1998). Secondly, the military government usually responded through state repression, which is germane to most dictatorial regimes in the world. This was the case in 1995, when renowned environmental crusader Ken Saro Wiwa and eight other Ogoni activists were extra-judicially murdered by hanging.

\section{Pre- and post-2009 scenarios}

The attainment of democracy on 29 May 1999 after protracted military rule did not appease the violent protests that had enveloped the Niger Delta region. Perhaps the freedom of expression that democracy offers was taken to the extreme when armed groups began to mobilize and challenge the very foundations of the 
Nigerian state. The Niger Delta People's Volunteer Force (NDPVF), founded by Alhaji Mujahid Asari-Dokubo, and the Niger Delta Vigilante (NDV), created by Ateke Tom, led more than 100 other smaller armed groups to violently engage the Federal Government and multi-national oil companies in a 'war of attrition'. Asari's NDPVF launched a series of attacks on oil wells and installations, disrupting oil production. The militant groups also attempted to control oil resources through oil bunkering, an exercise that involves tapping pipelines.

By September 2004, the Federal Government of Nigeria under President Olusegun Obasanjo had declared a full-scale war on the militants. The crisis worsened and Shell had to withdraw its personnel from two oil fields, causing oil production to be cut by 30,000 barrels a day. The crackdown on militants continued until 2008. The Joint Military Task Force combed the area and raided hideouts of militants in the creeks. In 2005-2006, the involvement of the most sophisticated armed group, the Movement for the Emancipation of the Niger Delta (MEND), also contributed significantly to reducing oil output. MEND's activities in the region extended to kidnapping for ransom and sea piracy. In other instances, it became part of the political machinery for dealing with local opposition in the 2011 elections (Pérouse de Montclos 2012). These unwholesome activities have caused thousands of residents to flee their homes and hundreds of people to lose their lives. In June 2009, the Federal Government declared its intention to grant an amnesty and unconditional pardon to militants as a way of restoring peace to the volatile region. The late Head of State, President Musa Yar'Adua, signed the amnesty programme, which officially began in October 2009. Before then, militants were given a 60 -day period to surrender their weapons in exchange for training and rehabilitation.

\section{Methodological issues}

Coming to terms with a statistical analysis of fatal deaths within the province of oil production and distribution requires that I clarify two important methodological issues. This is because the study of violence remains one of the most complex and contested areas of research. The domain of violence was, for instance, extended by Galtung (1969) to include 'structural violence', that is, physical or psychological injuries that may arise from unjust social and political relations. Hence, one of the methodological questions that this research raises is how to measure the intensity of violence without having to overstate the problem. The second pertinent question relates to how the data sources can be representative enough without violating the credibility of the research findings. First, it is almost impossible to exhaustively measure the weight of violence that attends cases of oil production and distribution in Nigeria, especially as this involves gener- 
ating consistent numerical data that will stand the test of time. What seems achievable under such conditions is to streamline the focus of the research to the numbers of deaths. Focusing on the body count helps to identify violent incidents that record at least one death. On the second issue, the research examined only open sources, which the Nigeria Watch database has so far provided generously with regards to its online data on fatalities in Nigeria. The police are grossly ineffective in the collation of reliable data for the purposes of accuracy and record keeping. The Nigeria Watch database is primarily based in a consistent manner on print media reports on violent incidents. It also cross-checks from other sources such as the Federal Road Safety Commission (FRSC), human rights organizations, and other credible sources to provide a clear picture of events. The preferred media reports have been carefully selected to give the process a national spread. Although the database is limited in terms of coverage, it remains a potent tool for trend analysis of events. Moreover, print media is the only credible open source that is consistent and accessible to the public. For all its shortcomings, the Nigeria Watch database is able to highlight and underscore valid assumptions about the violence associated with oil production and oil distribution in Nigeria.

\section{Key findings}

\section{Major causes of violent deaths in Nigeria (June 2006-May 2014)}

Figure 1.2 summarizes the overall picture of fatalities within the period of this research (June 2006 to May 2014). It shows that crime, car accidents, religious clashes, political violence, fire explosions, and oil distribution are the main drivers of fatalities in Nigeria. At present, the spotlight is on the Boko Haram insurgency as a cause of major violence in the country, and this violence is largely interpreted in the database as political and religious. In other words, oil distribution and production are not the main causes of violence. Nevertheless, it is important to compare the figures in oil production with oil distribution. With 4,575 deaths, oil distribution accounted for the sixth-highest number of violent cases in Nigeria. Oil production, which recorded 1,550 deaths, accounted for the tenthhighest number. The combination of the two figures accounts for some 6,125 deaths.

\section{Fatalities caused by oil distribution (June 2006-May 2014)}

Figure 2.2 shows there has been a downward trend in annual violent deaths in oil distribution, except in the years 2009 and 2012. In fact, 2009 had an exceptionally high number of fatalities, with a staggering casualty figure of 1,089. The major event here was an outbreak of violence in Warri South and Warri South West 
LGAs, where a fatal clash between soldiers and militants over illegal refineries and oil bunkering led to the loss of 593 lives. The fatality record of 957 in 2006 was also extraordinarily high, bearing in mind that the figure covers just seven months (June-December). Road accidents and pipeline vandalism formed the main drivers of oil violent deaths in 2006. But it is important to note that the general trend since 2006 has been one of decrease, aside from the aforementioned years (2009 and 2012). As a matter of fact, 2014 presented the lowest number of violent deaths (23), even though it must be admitted that the figure represents just the first five months of the year. One cannot readily offer a cogent explanation for the marked variations in the fatality profile of the eight-year study, but what seems convincing is the fact that violent events are products of increasingly intense activities (both legal and illegal) around oil. A further study of the database found that 2008 witnessed 122 fatal incidences, most of which revolved around the activities of the JTF. There were 40 deadly incidents in 2006, despite its only seven-month coverage. The years 2013 and 2014 witnessed 25 and five incidents, respectively. The case of 2014, with just five incidents, is partially understandable in that it covers just five months (January-May).

Figure 2.2 Annual number of deaths caused by oil distribution (June 2006-May 2014)

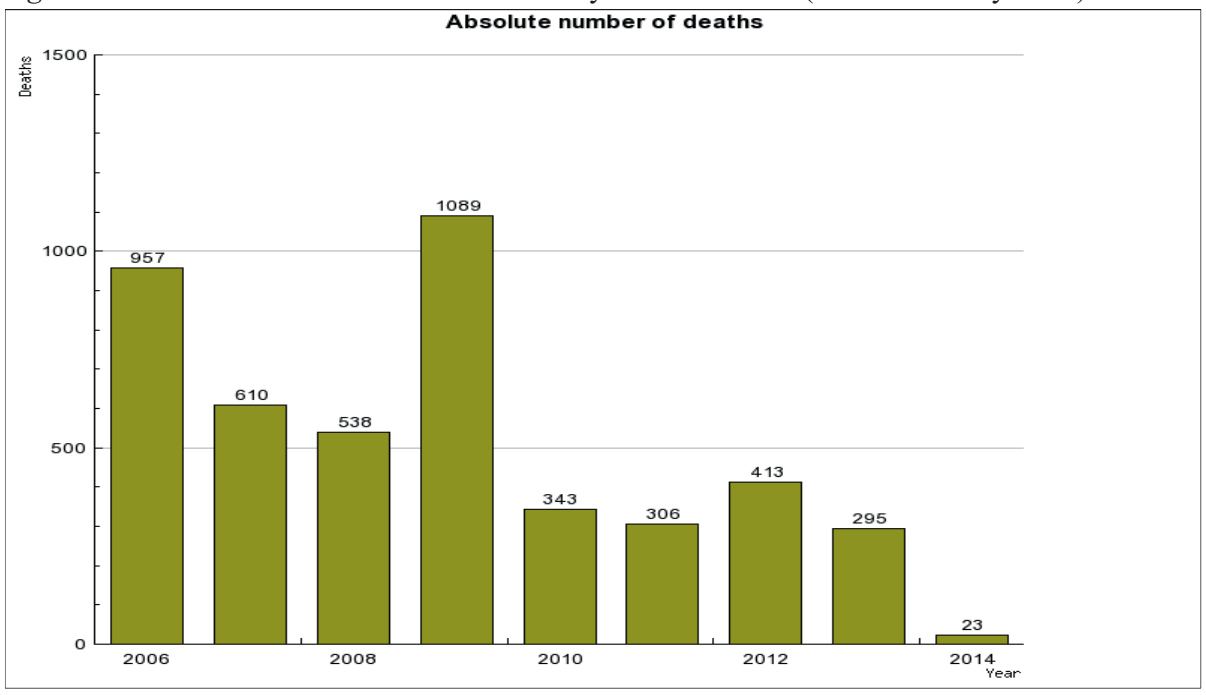

Figure 2.3 shows that 34 states in Nigeria, including FCT (Abuja), have witnessed fatalities in oil distribution. With the exception of Kebbi and Zamfara states, every state across the country has recorded at least one event of violence 
due to oil distribution. Again, of the total number of 4,575 deaths attributed to oil distribution, over 1,200 cases were recorded in Lagos State alone, followed by Delta State with approximately 850 fatalities. Other high-risk states for violent death from oil distribution include Rivers, Edo, Oyo, Ogun, and Bayelsa. There are two fundamental issues that could explain this trend. First, states that have a high demand for PMS are most prone to fatalities. The level of demand for petroleum products can at times be determined by the population density and the level of industrial activities in the states. Lagos and Delta, for instance, fit perfectly into this context. Lagos sea-terminals provide the routes through which oil products and other heavy goods are imported into the country, to service the South West and some northern states. Hence, heavy traffic of trailers and light vehicular movements are common features on Lagos roads. The second point to make is the obvious fact that oil distribution activities are more fatal outside the states of oil production. For instance, the total death figure for oil production observable within the oil production areas is considerably less than 2,000, whereas 4,575 fatal deaths occurred in the country as a whole as a result of oil distribution. The frequency of fatal events in oil distribution between June 2006 and May 2014 also shows the high-risk states to be Bayelsa (99), Lagos (79), Delta (56), and Rivers (51). Oil spillage and the activities of the JTF are largely responsible for the frequency of violence in Bayelsa State. In Delta, road accidents that involved petrol tankers, kerosene explosion, pipeline vandalism, and piracy were major causes of fatal incidents. In Lagos, tanker explosions, road accidents, robberies at fuel stations, oil theft, and pipeline vandalism loomed large.

Figure 2.3 Deaths due to oil distribution, by state (June 2006-May 2014)

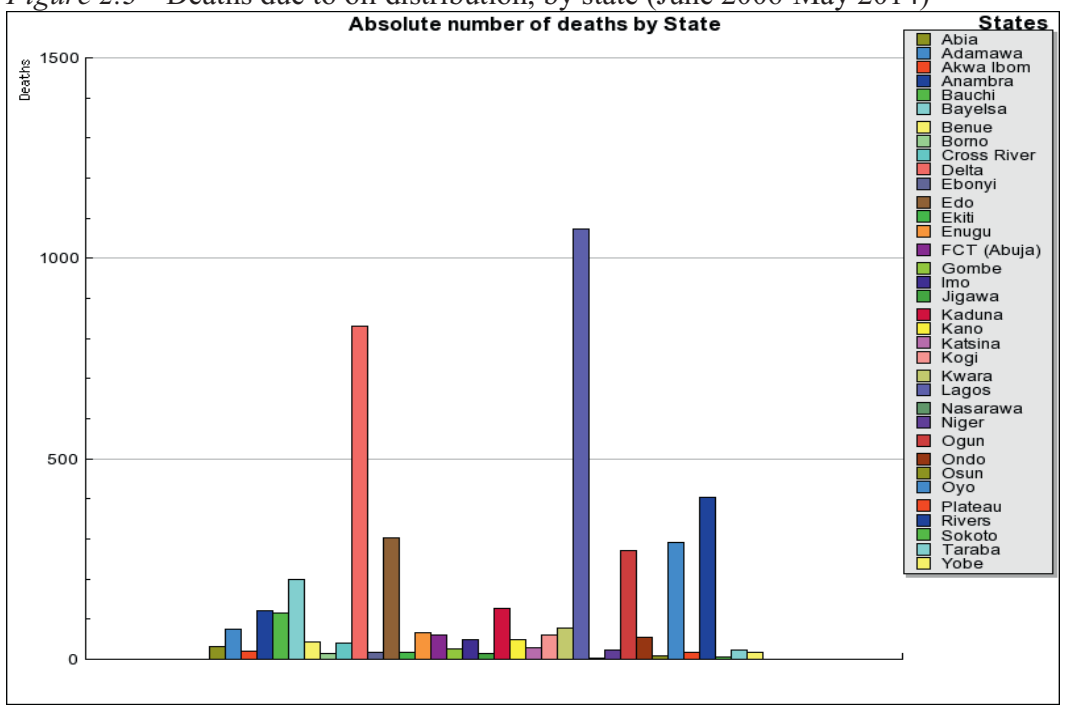


Map 2.1 shows that the incidents related to oil distribution cover virtually all parts of country, with Lagos and Delta representing the areas of highest casualties. The Map also shows that only two states (Kebbi and Zamfara in the NorthWest) did not have records of fatalities arising from oil distribution.

Map 2.1 Fatalities resulting from oil distribution in Nigeria (June 2006-May 2014)

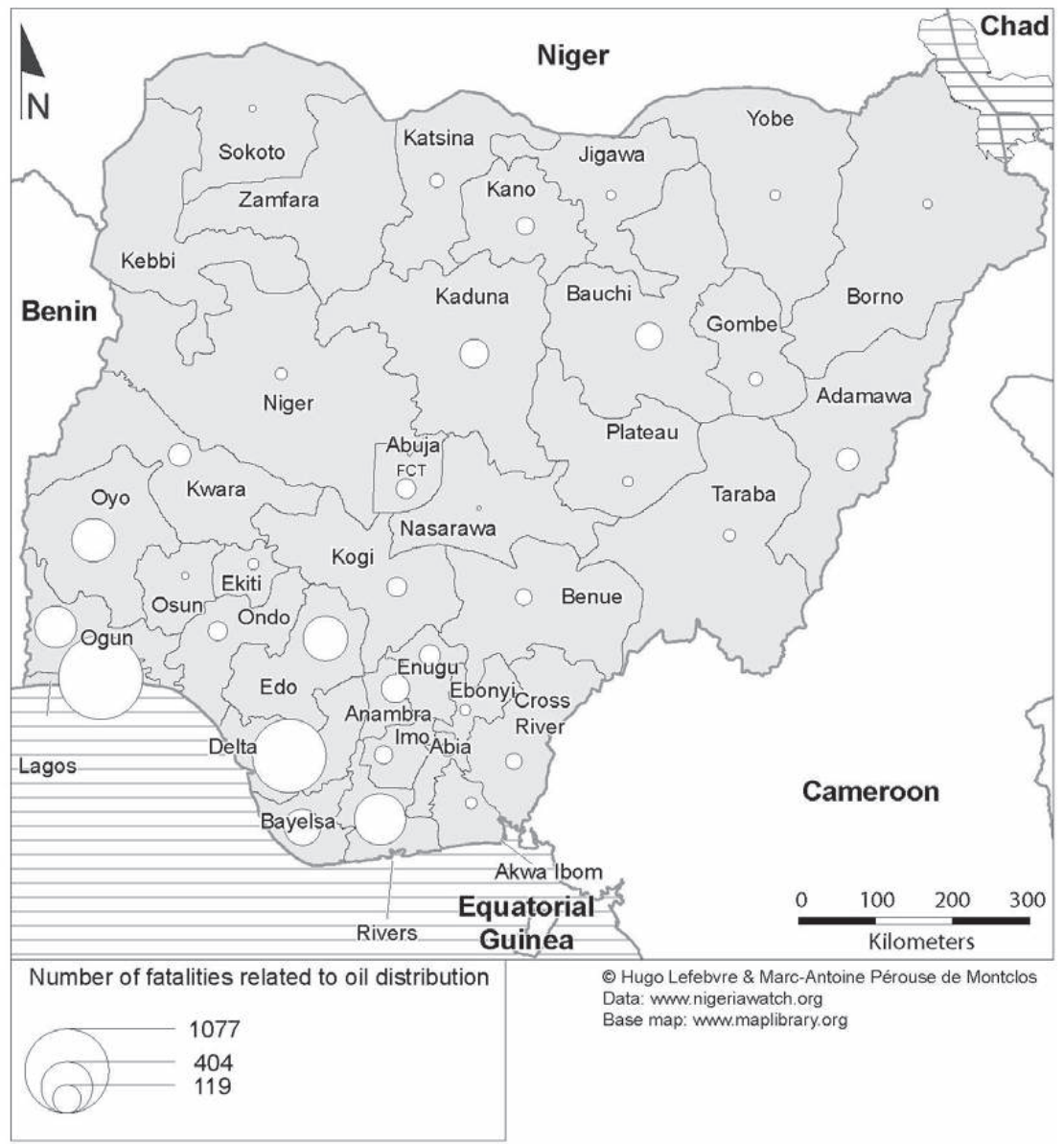

When the cases per 100,000 inhabitants are mapped, Map 2.2 shows Delta as the most violent state, followed by Lagos and Rivers states. Normally, the absolute figures concentrate on Lagos State as the most fatal in terms of frequency and intensity of the problem. However, the risk assessment analysis shows Delta as the most dangerous state for oil distribution because it has the highest relative violent death figures. 
Map 2.2 Fatality rates resulting from oil distribution in Nigeria, per 100,000 inhabitants (June 2006-May 2014)

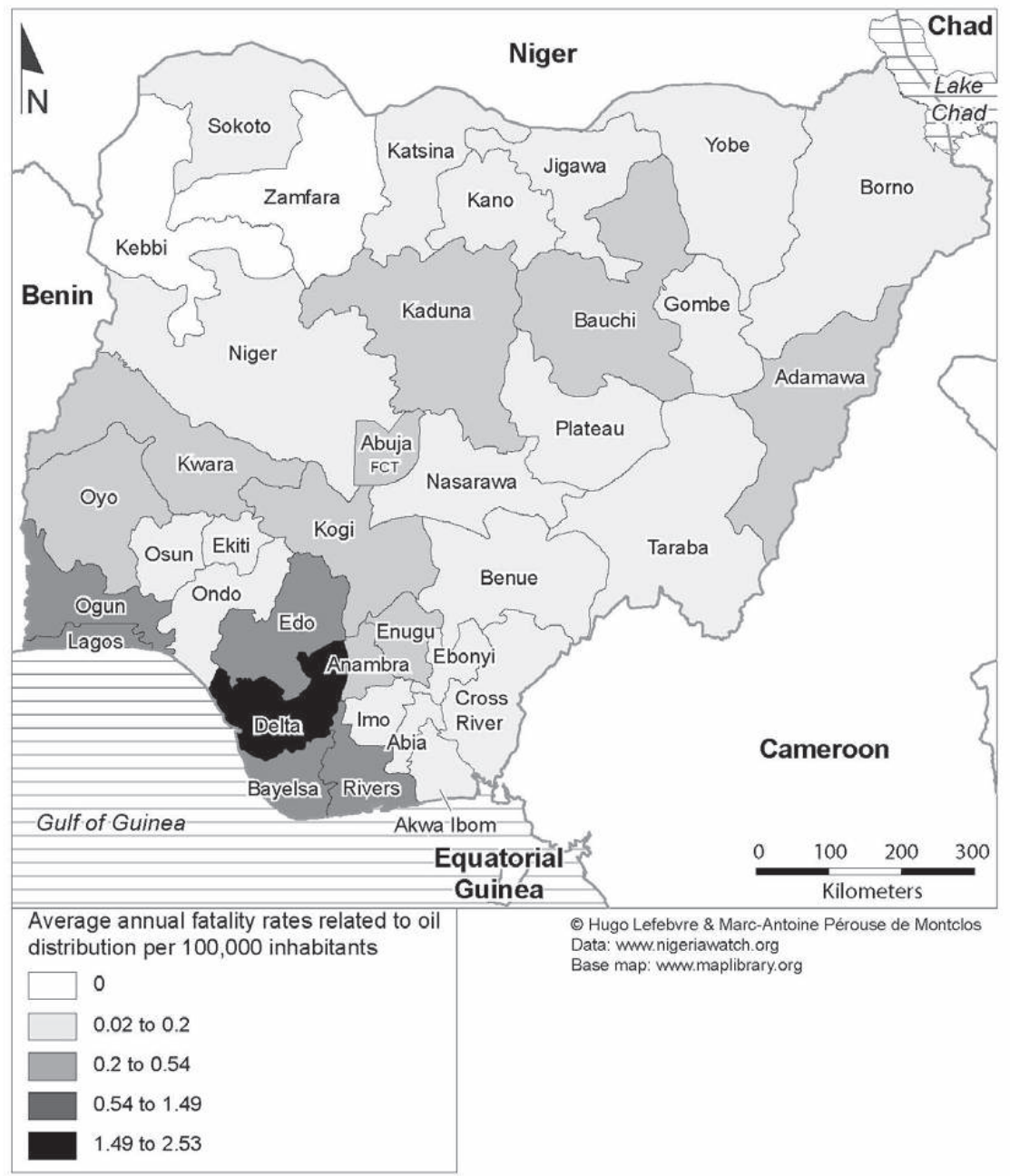

Fatalities caused by oil production (June 2006-May 2014)

Between 2006 and 2014, oil production activities precipitated some marked incidences of violence, mainly and quite obviously in the zones of extraction. As shown in Figure 2.4, there was a steady increase in the number of violent deaths recorded between 2006 and 2009, after which there was a sharp drop from 722 to 70 deaths. The trend picked up again from 2012 to 2013 but witnessed another sharp drop to only one death related to oil production in 2014. Generally, oil production has led to far fewer fatalities than oil distribution. 
Figure 2.4 Violent deaths caused by oil production (June 2006-May 2014)

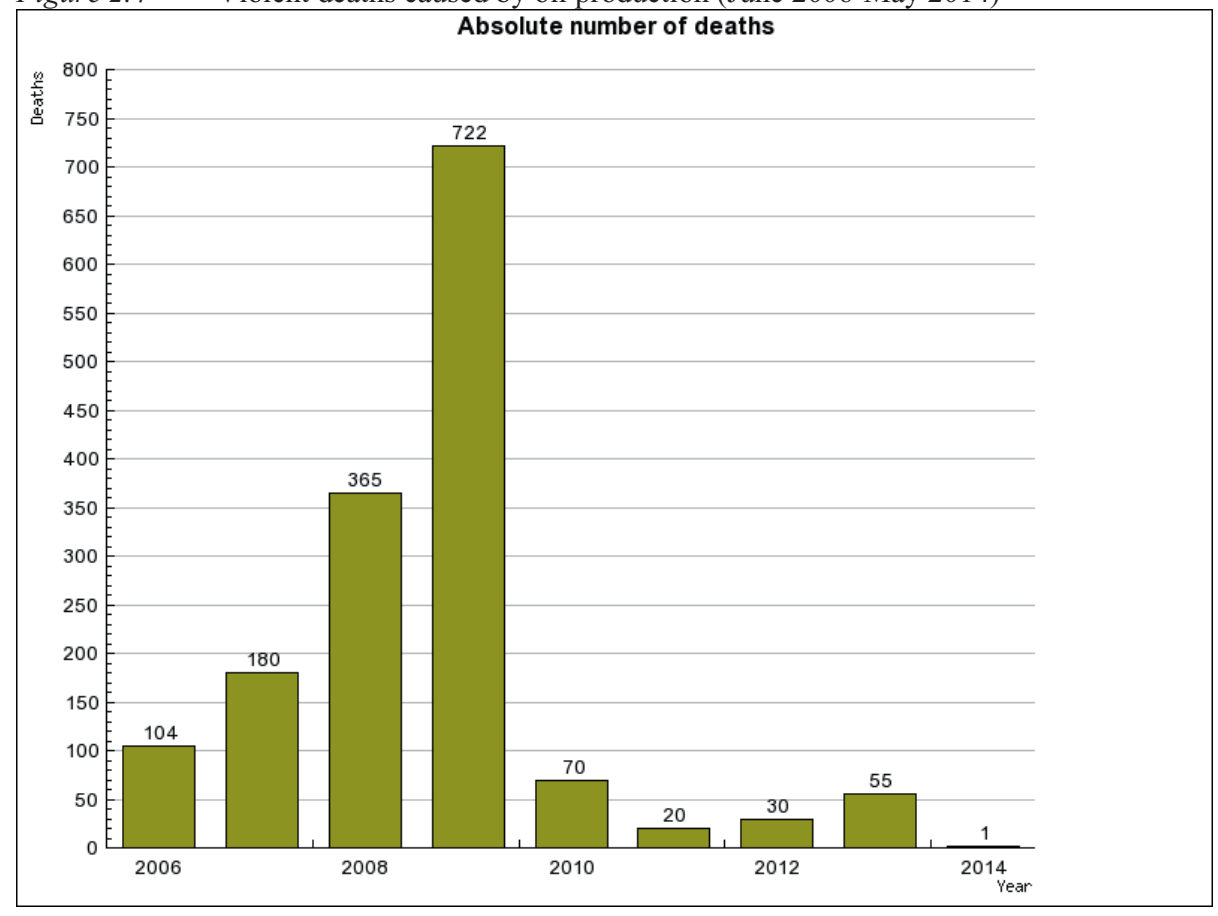

Since oil production activities take place mainly within the Niger Delta states, it is only logical that most of the violence is concentrated in this region. The oilrich states (Delta, Rivers, Bayelsa, Akwa Ibom, Cross River, Abia, Anambra, and Imo) present various degrees of fatalities arising from oil production activities (Figure 2.5). In terms of the frequency of incidents, Bayelsa was the most affected, with over 117 incidents recorded between June 2006 and May 2014, followed by Rivers and Delta states with 65 and 35 events, respectively. Some 14 deaths were observed in Kogi State due to frequent clashes over oil deposits at the border between Aguleri and Achewno communities in Anambra and Kogi states. However, it is possible that some of the violence documented in Anambra was also recorded in the cases that involved Kogi State. The aggregate death figure for oil production stands at 1,550. This is a far cry from the figure for oil distribution, which accounted for 4,575 deaths in the same period. This is a clear indication that oil distribution activities are more deadly than those of oil production. 
Figure 2.5 Number of deaths resulting from oil production, by state (June 2006-May 2014)

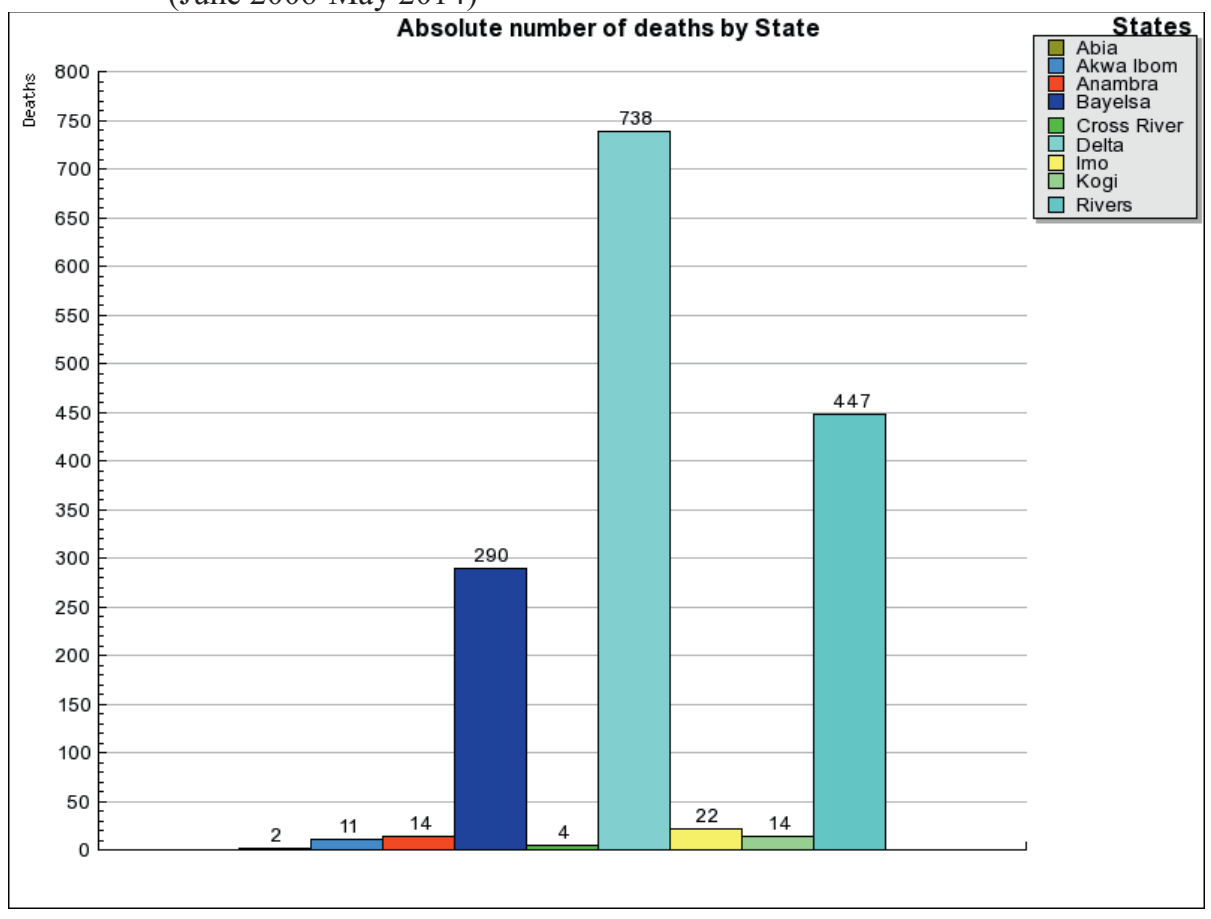

The data in Figure 2.5 can further be mapped to show the geographical concentration of oil production violence in Delta, Bayelsa, Rivers, Abia, Akwa Ibom, Imo, Anambra, and Cross River states (Map 2.3). Again, Delta State has the highest fatality profile in oil production, while Rivers, Bayelsa, Imo, Anambra, Kogi, Cross River, and Abia states follow in that order. The issues that led to violence in those states also vary considerably. In Bayelsa, the issues revolve mainly around oil spillage and the clashes between the JTF and militants. JTF attacks and pipeline vandalism were also prevalent in Delta. Of particular note was a deadly encounter between the JTF and militants in May 2009, as noted earlier, that claimed the lives of almost 600 people, including women and children. 
Map 2.3 Fatalities resulting from oil production in Nigeria (June 2006-May 2014)

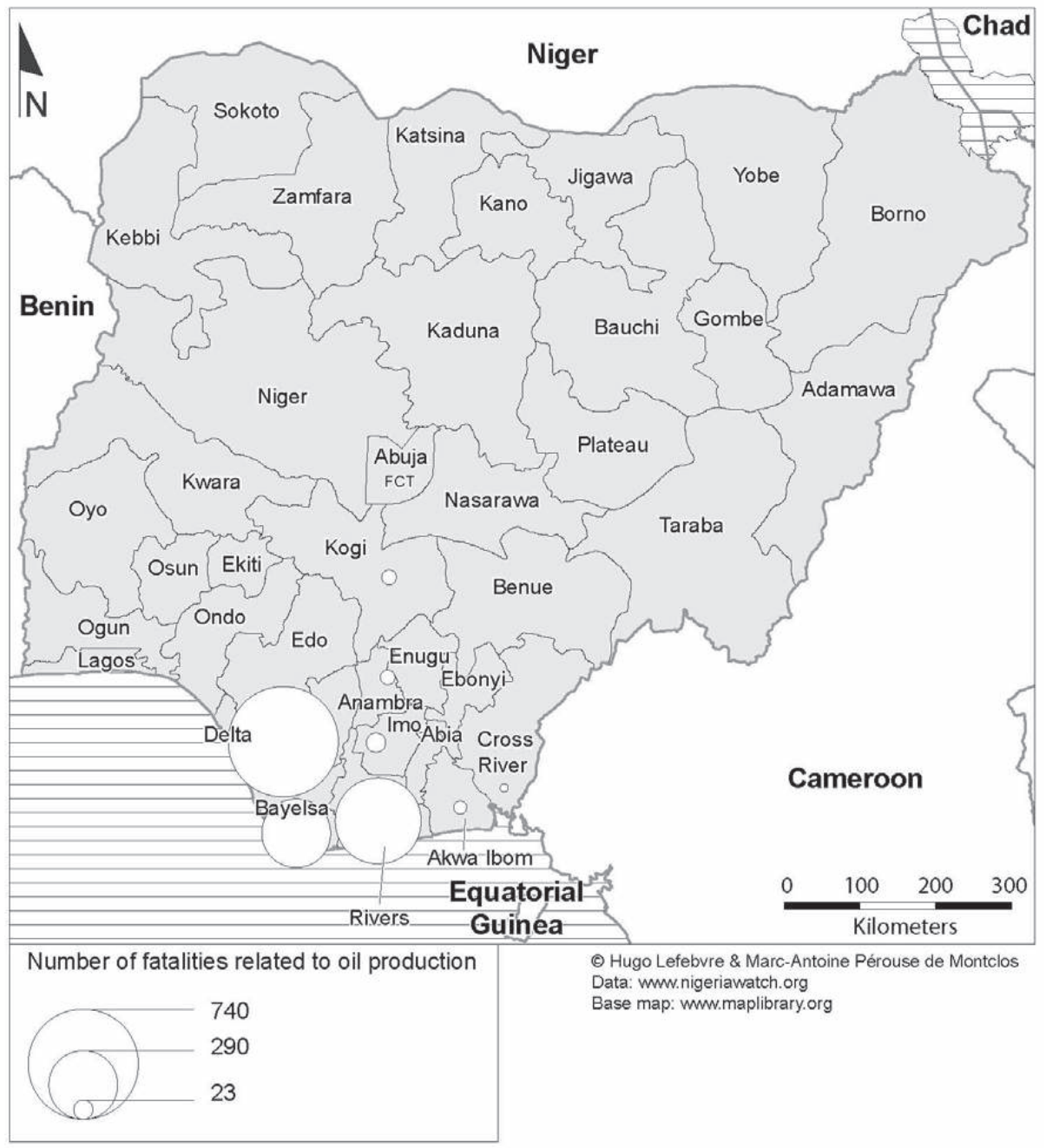

The rate per 100,000 inhabitants of violent deaths related to oil production is shown in Map 2.4. From this analysis, Delta, Bayelsa, and Rivers appear as the most dangerous states. This is not really surprising, considering the fact that they are the core oil-producing states of the Niger Delta. 
Map 2.4 Fatality rates resulting from oil production in Nigeria, per 100,000 inhabitants (June 2006-May 2014)

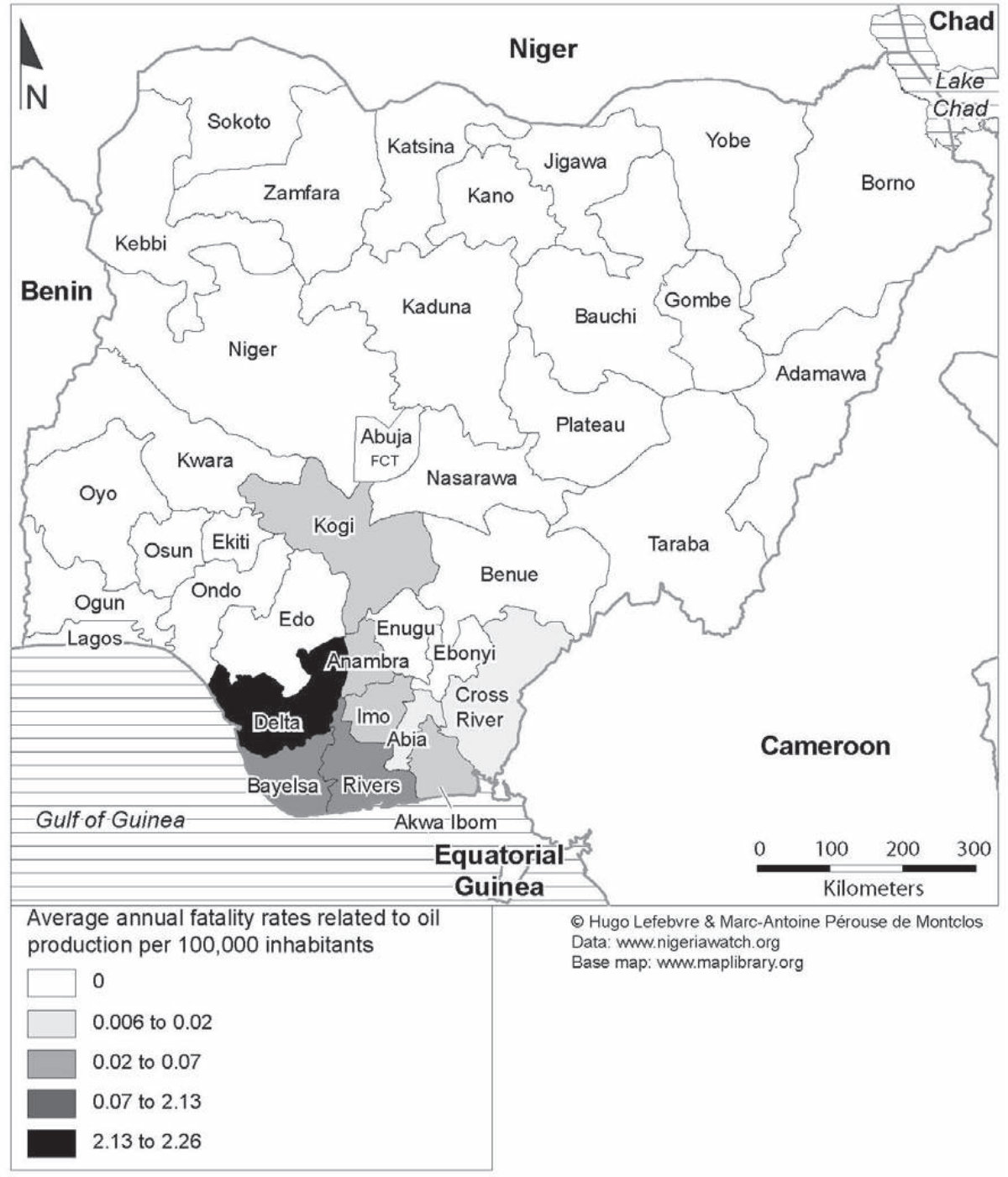

\section{Oil production versus oil distribution}

Perhaps the first point to make in this section is that oil causes fewer than $10 \%$ of the fatalities reported in violent incidents in Nigeria, much fewer than road accidents, crime, and religious or political clashes. Figure 1.2 clearly illustrates this point by rating oil violence, that is, oil distribution and production combined, as 
the sixth-highest cause of lethal violence in Nigeria. However, oil-related violence has been rather brutal in terms of intensity and national spread. An important fact is that oil distribution activities have a strong link with road accidents. Most fatal accidents on the highways are indeed connected to the movement of petroleum products to different parts of the country. The point was made earlier in this paper that the demand for PMS impacts on the number of violent deaths that are likely to occur in a particular location. Hence, locations such as Lagos, Delta, and Rivers states have always had high fatality cases because of the concentration of industries in these states.

Secondly, from the analyses presented above, oil production and oil distribution differ with respect to their contribution to lethal violence across the country. Oil distribution is far more violent than oil production. This can be explained in a number of ways. In the first instance, the activities that involve oil distribution are nationwide, while oil production operations are restricted to the Niger Delta region, with a few cases in Kogi State because of its border problems with Anambra State. The impact of oil distribution on violence is therefore more widespread geographically. In fact, the only states that did not have incidents of oil distribution violence since 2006 are Kebbi and Zamfara (Figure 2.3). By contrast, oil production violence took place only in states such as Delta, Bayelsa, Rivers, Akwa Ibom, Cross River, Anambra, Imo, and Kogi.

Other factors that make oil distribution a more deadly operation than oil production are worth mentioning. The point was previously made that oil distribution is closely tied to road accidents, which are one of the main causes of fatalities in Nigeria. The dilapidated state of the roads, poor maintenance of tankers, and rampant reckless driving have made the movement of petroleum products to the various parts of the country dangerous undertakings. This point is germane considering the current comatose state of the Nigerian rail system and, of course, the fact that pipelines have become major targets for destruction by vandals and those creating oil bunkers. In addition, the poorly maintained status of most heavy vehicles (i.e. trailers being used to convey these products) makes oil distribution activities more prone to fatal incidents. Since petroleum products are highly inflammable, they easily cause lethal fire explosions whenever accidents involving petrol tankers occur. Taiwo (2013) listed mechanical, environmental, institutional, natural, and supernatural factors as responsible for road accidents on the highways (see also Bum 2012). All these variables come into play whenever petroleum products are distributed to different parts of the country. 


\section{Conclusion}

It is important to stress at this concluding stage that the multifarious violence that constantly besets the oil industry is not the main source of fatalities in Nigeria. Nevertheless, the impact of the oil industry is far from insignificant, and it also varies with respect to scope and intensity according to which aspect of the industry we consider. One of the issues raised in this paper is the fact that oil distribution is considerably more deadly than oil production. The analyses also show that fatalities due to oil production are concentrated in the Niger Delta region, while those due to oil distribution are a nationwide affair. There is also a marked discrepancy in both absolute and relative numbers of deaths for oil distribution and oil production. All these are pointers to the complex contribution of oil distribution to the violent incidences that frequently beset the oil industry. This paper advocates further empirical studies in order to gain more insights into the dynamics of oil distribution and production in Nigeria.

\section{References}

AgBu, O. (2004), Constitutionalism and Minorities' Rights Struggles in Nigeria: Implication for the Nation-State. Amani Journal of African Peace 1(1): 35-57.

AKPABIO, E.M. \& N.S. AKPAN (2010), Governance and Oil Politics in Nigeria's Niger Delta: The Question of Distributive Equity. Journal of Human Ecology 30(2): 111-121.

BUM, E. (2012), Road Traffic Accidents in Nigeria: A Public Health Problem. AFRIMEDC Journal 3(2) (July-December).

EdoreH, A. (1997), Future of Nigerian Petroleum Industry. Lagos: Academy Press.

Ehinome, C. \& A. AdeleKe (2012), An Assessment of the Distribution of Petroleum Products in Nigeria. Journal of Business Management and Economics 3(6): 232-241.

EKE, M.N. \& S.O. ENIBE (2007), Optimal Scheduling of Petroleum Product Distribution in Nigeria. Nigerian Journal of Technology 26: 1 (March).

FALOLA, T. (2009), Colonialism and Violence in Nigeria. Bloomington: Indiana University Press.

Galtung, J. (1969), Violence, Peace and Peace Research. Journal of Peace Research 6: 167191.

Guichaoua, Y. (2009), Oil and Political Violence in Nigeria. In: J. Lesourne \& W.C. Ramsay, eds, Governance of Oil in Africa: Unfinished Business. Paris: IFRI.

IKelegbe, A. (2005), Multinational Corporate Governance, the Emergent Political Economy of Oil and Communal Cohesion in the Niger Delta Region of Nigeria, being a final research report submitted to IFRA, Ibadan.

IKPORUKPO, C.O. (2002), In the Name of Oil: The Nigerian Civil War and the Niger Delta. In: E. E. Osaghae, E. Onwudiwe \& R. Suberu, eds, The Nigerian Civil War and Its Aftermath. Ibadan: PEFS.

KARL, L.T. (1997), The Paradox of Plenty: Oil Booms and Petro-States. Berkeley: University of California Press. 
OBI, C. (2005), Oil and Federalism in Nigeria. In: E. Onwudiwe \& R. Suberu, eds, Nigerian Federalism in Crisis. Ibadan: PEFS.

OBI, C. (2009), Nigeria's Niger Delta: Understanding the Complex Drivers of Violent OilRelated Conflict. African Development 35(2): 103-128.

OgBogbo, C.B.N. (2002), The Niger Delta Peoples and the Resource Control Conflict, 19601995: An Assessment of Conflict Handling Styles. In: I.O. Albert, ed., Perspectives on Peace and Conflict in Africa. Ibadan: Peace and Conflict Studies.

Ojakorotu, V. \& O. Olawale (2009), Understanding the Niger Delta Conflict: Matters Arising. In: V. Ojakorotu, ed., Contending Issues in the Niger Delta Crisis of Nigeria. JAPSS Press: Houston.

Osaghae, E.E. (1995), The Ogoni Uprising: Oil Politics, Minority Agitation and the Future of the Nigerian State. African Affairs 94: 325.

Osaghae, E.E. (1998), Managing Multiple Minority Problems in Divided Society: The Nigerian Experience. The Journal of Modern African Studies 36(1): 1-24.

PÉRouse De Montclos, M.-A. (2012), Maritime Piracy in Nigeria: Old Wine in New Bottles. Routledge, Taylor \& Francis Group Online.

PÉRouse DE Montclos, M.-A. (2014), Fourth Report on Violence in Nigeria (2006-2014). www.nigeriawatch.org.

Sala-I-MARTin, X. \& A. Subramain (2003), Addressing the Natural Resource Curse: An Illustration from Nigeria. NBER Working Paper No. 9804, Cambridge, MA: National Bureau of Economic Research (NBER).

Smith, D.J. (2007), A Culture of Corruption: Everyday Deception and Popular Discontent in Nigeria. Princeton NJ: Princeton University Press.

TAIWO, V.O. (2013), Road Accidents: I Wish Mine Were the Last. Ibadan: Omoade Publications. 


\title{
Trends and patterns of cattle grazing and rural violence in Nigeria (2006-2014)
}

\author{
Philip Ademola Olayoku ${ }^{1}$
}

\begin{abstract}
Relying on the Nigeria Watch database data from June 2006 to May 2014, this study analyses the root causes, dynamics, evolution, and politicization of cattle grazing conflicts in Nigeria. After reviewing the historical, political, and socioeconomic contexts, it identifies the key actors in lethal rural violence from cattle grazing to be herdsmen, farmers, community members, vigilantes, security operatives, government officials, and, in rare cases, religious leaders. The study also highlights the intensity and the time frame of such violence. No cycles were identified. The North Central region appears to be the hotbed of these conflicts, though the problem remains spread across different parts of the country and occurs at different times of the year.
\end{abstract}

\section{Introduction}

The recent classification of some Fulani herdsmen as Boko Haram collaborators by the Nigerian military and politicians (McGregor 2014) reveals the complexities of violent clashes between cattle breeders and sedentary agriculturalists across different parts of the country. The alleged involvement of camel pastoralists from the Republic of Niger in some conflicts in the north-western and central regions of Nigeria also highlights the need to investigate the multidimensional causes and the politicization of a problem that spills over to neighbouring countries (Blench 2010; Krause 2011; Abbass 2012; Audu 2013; McGregor 2014). Blench (2010), for instance, analyses the relationship between herdsmen and farmers as an economic exchange of dairy products for grain, access to local markets, and the provision of manure on arable land while the cattle consume crop residues. However, he claims that religious and cultural factors, among oth-

\footnotetext{
1 Thanks are owed to David Lamoureux and Conrentin Cohen for reading drafts of this paper.
} 
ers, are key to peaceful relationships that became less cordial as the Fulani migrated further south. This has led to several agitations in the past, notably by the Miyetti Allah Cattle Breeders Association of Nigeria (MACBAN), which advocates for the social, political, economic, and cultural integration of Fulani in communities where they settle (Awogbade 1987).

Climate changes, the migration further south, the growth of agro-pastoralism, the expansion of farming on pastures, the invasion of farmlands by cattle, assault on non-Fulani women by herders, blockage of stock routes and water points, freshwater scarcity, burning of rangelands, cattle theft, inadequate animal health care and disease control, overgrazing on fallow lands, defecation on streams and roads by cattle, extensive sedentarization, ineffective coping strategies, ethnic stereotyping, and the breakdown of conflict intervention mechanisms - these are usually identified by scholars as the root causes of such violence in rural areas (Folami 2009; Ofuoku \& Isife 2009; Adekunle \& Adisa 2010; Blench 2010; Odoh \& Chigozie 2012; Solagberu 2012; Audu 2013, 2014; Bello 2013; McGregor 2014). In line with this, Abbass (2012) contends that the major source of tensions between pastoralists and farmers is basically economic, with landrelated issues accounting for the majority of the conflicts. This can then be situated within the broader context of the political economy of land struggle, traceable to a burgeoning demography in which there is fierce competition for fixed space to meet the demands of the growing population (Olabode \& Ajibade 2010; Solagberu 2012).

However, Blench (2010) has observed that ecological and economic determinism may not capture the complexities embedded in the conflict contexts of these groups. Sellen (1996) also advocated for contextual analyses of 'local socioecological conditions' and diversity of pastoral populations in accounting for their nutritional habits. Therefore, there is a need to overcome the socio-cultural stereotyping of the nomadic life and relate experiences to their contexts, while taking cognisance of the holistic functioning systems of local economies (Gefu \& Gilles 1990). In more recent times, transhumant herdsmen coexist with agropastoralists and farmers who have also taken to cattle breeding (Awogbade 1987), and this has redefined their perceptions of and relationships with each other. Of these herdsmen, the Fulani are highly visible. Yet there are about 14 other groups who practise pastoralist activities in Nigeria, including the Arabs, Kanuri, Kanembu, Shuwa, and Touareg (Braukamper 1996; Blench 2010).

Within this context, it is pertinent that researchers engage the complexities of these relationships rather than jump to quick conclusions. From a methodological point of view, the problem is that violence from cattle rearing is not well reported. In the past eight years, this violence accounted for 615 of the 61,314 fatalities recorded in the Nigeria Watch database. A major reason for this neglect may be 
the location of the occurrence of incidents in rural and, sometimes, border areas that are neither easily accessible nor attractive to reporters. Journalists often prefer to capture the 'trendier' news of insurgencies from Niger Delta militants or Boko Haram, which have taken the limelight and captured people's interest. Moreover, stereotypes abound about the Fulani herdsmen, as issues related to their occupation are sensationally alluded to in political and religious contexts. However, this has in no way lessened the negative effects of fatalities from cattle grazing, as will be subsequently discussed in this study. Undoubtedly, the loss of human lives, land, animals, plants, and crops has many security, social, political, and economic implications, including an impact on livestock production in Nigeria (Folami 2009; Adekunle \& Adisa 2010; Bello 2013).

In this study, the focus will be on the Fulani because of the scope of their pastoral activities and their political visibility. The attacks by Fulani herdsmen have in recent years taken more sophisticated dimensions with the use of new types of weapons and communication devices. In consequence, the sedentary agrarian communities have resorted to self-defence through local vigilante groups (Abbass 2012; McGregor 2014). ${ }^{2}$ This has further aggravated violence, with destruction of lives and properties. According to Fasona and Omojola in 2005, conflicts resulting from cattle grazing actually accounted for $35 \%$ of all reported crises between 1991 and 2005 in Nigeria (Adekunle \& Adisa 2010). The North Central states of Taraba, Nasarawa, Plateau, and Benue have also been identified as the most affected areas in the country (McGregor 2014; Nigeria Watch Newsletter 2014).

\section{Historical, political, and socio-economic context of pastoralist-farmer conflicts in Nigeria}

According to Azarya (1996), the Fulani pastoralists of West and Central Africa trace much of their current political, religious, and socio-cultural identity from the $18^{\text {th }}$ and $19^{\text {th }}$ century jihad, which sedentarized them within conquered communities. The Fulani are said to originate from Senegambia, before spreading across some 20 states in West Africa and the Sahel, up to Western Sudan and the Central African Republic (Blench 1994; Shehu \& Hassan 1995; Blench 2010; McGregor 2014). In Nigeria, they are the mainstay of the meat and milk industry, accounting for about $90 \%$ of cattle herd ownership, which makes up $3.2 \%$ of the country's GDP (Abbass 2012; Koster \& de Wolff 2012). They rear different species of cattle, such as the Keteku, Muturu, and Kuri, but the Zebu is identified as

The adoption of vigilante groups is not specific only to Nigerians. Pastoralists in the north-western region of Cameroon also adopted this measure to check cattle theft (Manu et al. 2014). 
the most common (Awogbade 1987; Iro 1994). They also supply skins, bones, and horns as complementary products.

The pastoralist system involves young men who tend the herd, while the women cook and sell animal products in the markets. ${ }^{3}$ The elders, in their own stead, are in charge of developing and managing resources at the levels of the community and domestic units (Awogbade 1987; Iro 1994). Despite the development and the centralization of the state dating back to the colonial era, these informal governing mechanisms have been key to understanding the challenges the pastoralists face with farmers, explaining their social stratification and their seemingly egalitarian nature (Dyson-Hudson 1990; Bradburd 1996; Okello et al. 2014).

From a historical point of view, certain scholars refer to the fact that conflicts resulting from cattle grazing have existed for as long as the practice of agriculture (Blench 2010; Abbass 2012). In the Nigerian context, however, colonization, together with the fall of the Sokoto caliphate and the introduction of jangali (cattle tax), marginalized the Fulani and dispersed them further towards the South (Azarya 1996; Okello et al. 2014). According to Ofuoku and Isife (2009), the advancement of farming through irrigation and the increased decimation of pasture across the savannah also extended the scope of transhumance-related conflicts to the coastal zones which were more ecologically viable (Blench 2010). This evolution was complemented by the provision of affordable trypanocides, which provided a coping means for the herders in the tsetse-infested humid regions of southern Nigeria (ibid.). Thus, the period from May to September, during the rainy season, has been identified as the intense period of clashes between pastoralists and farmers over arable land, when the Fulani return northwards with their cattle as the vegetation begins to appear. These clashes result from the invasion of arable land by the cattle during this peak season of crop production (Adekunle \& Adisa 2010; Abbass 2012).

The failure of the government in mediating such conflicts and setting up judicial commissions cannot be underestimated because it pushes communities to take the law into their own hands. After the initiation of the first national livestock development project (NLDP) and the enactment of a grazing law by the Northern Nigeria Legislative Assembly in 1965, the authorities attempted to provide grazing lands in order to make the nomadic Fulani sedentary (Awogbade 1987). In collaboration with organizations such as the International Livestock Research Institute (ILRI), the objective was to enhance productivity and to demarcate 4,125 grazing lands across Nigeria, covering about 4.3 million ha, some

This market role of women makes them important channels of communication between their communities and urban centres, transmitting vital information about prices, disease outbreaks, and trade conditions (see Shehu \& Hassan 1995). 
of the lands being equipped with boreholes, fences, fire breaks, veterinary services, access roads, and dams (Awogbade 1987; Abbass 2012; Koster \& de Wolff 2012). The predominant types of ranches were to be individually owned by farmers with large investments; there were few options for cooperatives and a collective management of the herds. Since 2009, grazing routes have also been marked out through Nasarawa, Benue, Plateau, Kastina, Bauchi, Abuja, Sokoto, and Adamawa. According to Abbass (2012), however, only 270 of these official grazing lands are functional.

\section{Cattle grazing and lethal violence: Analysis of trends across Nigeria (June 2006-May 2014)}

During the past eight years, the Nigeria Watch database has recorded 615 violent deaths related to cattle grazing, out of a total of over 61,000 violent fatalities in Nigeria (Figures 1.2 and 3.1). The analysis that follows was undertaken with 111 relevant cases, which were reported by the press across the 36 states of Nigeria from June 2006 to May 2014. It seeks to understand the frequency, the intensity, the patterns, and the geography of such violence, based on a study of 7 incidents in 2006, 9 in 2007, 6 in 2008, 13 in 2009, 9 in 2010, 15 in 2011, 17 in 2012, 27 in 2013, and 8 as at May 2014.

Figure 3.1 Violent deaths in Nigeria caused by cattle grazing, per year (June 2006-May 2014)

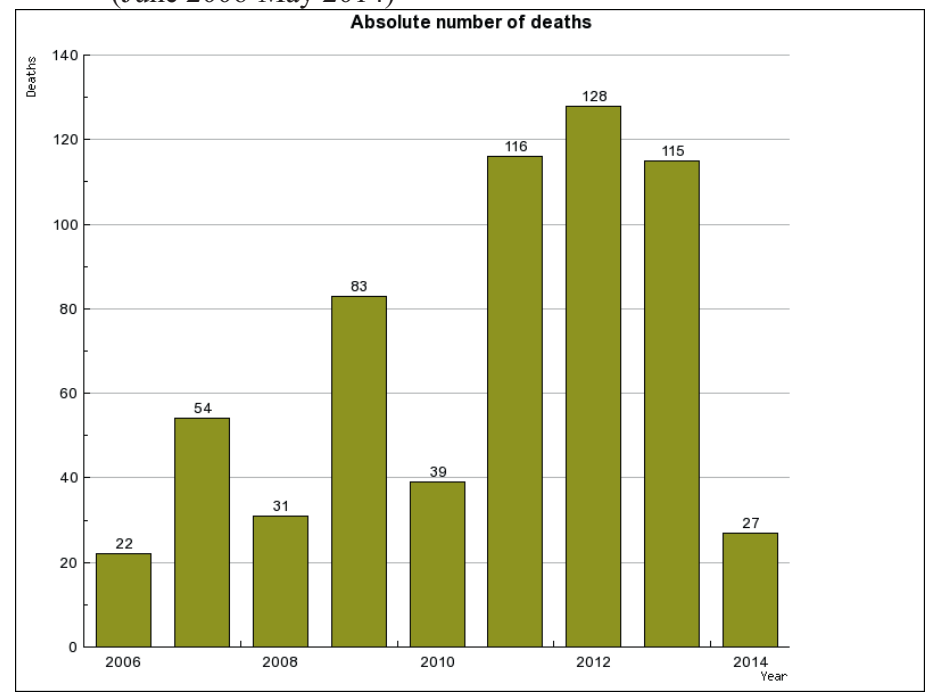


In the second half of 2006, 22 deaths resulting from cattle conflicts were recorded in the months of July (Imo and Kaduna), August (Zamfara and Rivers), and September (Kano, Delta, and Rivers). September accounted for the highest number of incidents per month (3), while Kano State was the most affected, with ten fatalities, followed by Rivers (five deaths in August and three in September). The main stakeholders involved were the police, the army, armed gangs, political groups, and communities, with victims on all sides. On 15 September 2006, for instance, soldiers were reported to have invaded the Elele Community in Rivers to avenge the disappearance of the cattle belonging to their 'fellow northerners'; however, another report claimed these were herdsmen dressed in army uniform. ${ }^{4}$

In 2007, the number of deaths resulting from cattle conflicts doubled to 54, spread across the months of January (Zamfara, Delta, and Osun), February (Jigawa), March (Cross River), June (Kebbi), July (Rivers), and December (Borno and Zamfara). Different weapons were used, from guns in Delta ${ }^{5}$ to bows, arrows, charms, cutlasses, and spears in Borno. ${ }^{6}$ The highest number of recorded incidents was in January, across Zamfara, Delta, and Osun. However, the highest number of casualties was recorded in Delta State, which accounted for 17 deaths as against 14 in Borno. The protagonists in the violence were usually armed gangs, the police, and communities. The Zamfara episodes in January and December also involved Fulani reportedly coming from the Republic of Niger. In most cases, the Fulani were perceived as aggressors, with allegations of rape and murder alongside those of destruction. However, in Kebbi, Jigawa, and Osun, they were portrayed as victims, with their villages razed by neighbours and their cattle either stolen or killed.

In 2008, reported fatalities resulting from cattle conflicts dropped to 31, occurring in the months of January (Jigawa), April (Anambra), July (Jigawa), November (Taraba), and December (Katsina and Jigawa). The highest number of incidents (5) occurred in the North (Jigawa, Kastina, and Taraba). However, the highest number of fatalities accounted for was in Anambra, with nine casualties, followed by Taraba and Jigawa, with seven and six respectively. The stakeholders in these clashes were largely Fulani herdsmen and farmers in communitybased conflicts. In all the reported cases, the Fulani were portrayed as aggressors because their cattle invaded farmland.

In 2009, the number of fatalities more than doubled the figures of the previous year, with 83 deaths spread over the months of April (Benue), June (Plateau and

4 http://www.nigeriawatch.org/index.php?urlaction=evtView\&id_evt=586\&rang=1. Accessed 11 September 2014.

5 Habu, I. (2007), 2 Policemen, 5 Others Die in Communal Clash. Daily Champion, 26 December 2007. http://www.nigeriawatch.org/index.php?urlaction=evtView\&id_evt=2936\&rang=1. Accessed 9 October 2014.

6 Musa, N. (2007), Seven Die in Borno Pastoralists, Farmers' clash. The Guardian. 25 December 2007. http://www.nigeriawatch.org/media/doc_acc/G2007-12-25.pdf. Accessed 9 October 2014. 
Jigawa), July (Jigawa and Benue), September (Borno), October (Kebbi), November (Imo), and December (Nasarawa, Oyo, and Zamfara). June, July, and December had the highest occurrence per month, while 11 of the 13 reported cases took place in the North. Jigawa again recorded the highest number of incidents, with four reported cases between June and July. Nasarawa had the highest number of deaths (47) in the most sustained crisis, which lasted two days: in addition, mercenaries were allegedly hired from the neighbouring states of Taraba and Kogi. The reported case in Borno also reflected trans-border actors from the Republic of Niger and Chad; in this case, rebels dressed in military uniforms and armed with sophisticated weapons raided Fulani communities in Abadam and Mallam Fatori. ${ }^{7}$

The 2010 incidents related to cattle grazing then dropped to 39 fatalities during the months of January (Adamawa and Oyo), February (Ogun), April (Plateau), May (Benue), June (Niger), July (Plateau), August (Adamawa), and October (Plateau). The highest number of reported incidents was two in January, while Niger State had the highest number of casualties (15). Out of a total of nine cases, seven occurred in the North. In Adamawa, where the international cattle market of Mubi attracted foreign robbers, the violence lasted for seven days. This particular case involved suspected Cameroonian armed bandits with sophisticated weapons. ${ }^{8}$ The use of sophisticated weapons and the portrayal of the Fulani as victims was also noted in a report on Plateau State by the spokesperson of MACBAN, when the Fulani clashed with Berom farmers and lost a young Fulani in addition to 30 cows. $^{9}$

The year 2011 saw a meteoric rise to 116 in the number of deaths resulting from cattle conflicts. These clashes occurred in January (Cross River and Plateau), February (Benue and Plateau), April (Abuja), May (Plateau), June, (Nassarawa and Benue), July (Imo), August (Plateau and Nasarawa), November (Kastina), and December (Zamfara). The highest number of incidents was in February and June, with states in the North accounting for the majority of the reported cases. The highest number of fatalities was recorded in Benue, with 38 in June and 27 in February. However, of the 15 reported cases in that year, Plateau State accounted for the highest number of occurrences with four incidents, while Benue and Nasarawa had three each. The most sustained violence lasted for five days in Benue, as against three in Nasarawa. The major cause of such conflicts was the invasion of farmland by cattle breeders, leading to attacks and reprisals from both groups. The high casualty figures recorded in Benue State were not unconnected with the spread of violence across different communities as people were dis-

\footnotetext{
7 Musa, N. (2009), Bandits Attack Three Communities, Kill One. The Guardian. 20 September 2009, p. 5 .

8 Onah, M. (2010), Trans-Border Bandits Kill 10 in Adamawa. ThisDay. 18 August 2010, p. 8.

9 Lalo, M. (2010), Fulani Herdsman, 30 Cows Killed in Jos. Daily Trust. 21 October 2010, p. 2.
} 
placed, and there was the alleged engagement of Fulani 'mercenaries' from Lake Chad, together with the use of sophisticated weapons, bulletproof vests, military uniforms, horses, and motorcycles. ${ }^{10}$

The highest number of deaths resulting from cattle conflicts was recorded in 2012, with the total number put at 128 during the months of January (Delta), February (Enugu, Taraba, and Nasarawa), March (Benue, Borno, and Delta), April (Nasarawa and Abuja), May (Nasarawa and Cross River), June (Taraba and Abuja), November (Jigawa), and December (Ogun). The highest number of incidents was four in February, while the highest number of fatalities was recorded in Cross River, with 40 casualties in May, though Benue had a total of 30 deaths in March. Also, of the 17 recorded cases, the states of the North recorded 12, especially in Taraba and Nasarawa. The most sustained incident lasted for three days in Nasarawa and Benue, while the key actors included soldiers, the police, Fulani herdsmen, and local farmers. In Nasarawa, for instance, 50 armed Fulani were reported to have attacked a border town (Shatse) at dawn, and both sides claimed casualties, including the loss of 500 cows. ${ }^{11}$ Some cases were even more complex. In Delta State, it was alleged that armed herdsmen, dressed in uniforms, were confronted by locals after their cattle had destroyed farms, women were raped, and some headless bodies were found. Also, the military were reported to have killed two persons in their bid to restore peace, though this was denied by their spokesperson. The search for northerners by indigenes for retaliation then gave an ethno-political dimension to the crisis. Former Niger Delta militants joined the conflict, with other youths allegedly robbing travellers and overpowering the police. ${ }^{12}$

The total figure for the reported casualties resulting from cattle conflicts dropped slightly in 2013 to 115 deaths spread across the 12 months: January (Benue), February (Delta), March (Benue and Kaduna), April (Plateau, Delta, and Kogi), May (Zamfara, Nasarawa, and Benue), June (Zamfara, Nasarawa, and Kaduna), July (Benue and Oyo), August (Nasarawa), September (Benue), October (Benue, Jigawa, and Katsina), November (Kwara and Sokoto), and December (Akwa Ibom and Bayelsa). The two most deadly crises were recorded in Benue, with 20 fatalities in September and 17 in May. The longest clashes lasted two days in Delta (February) and Benue (September), while 22 of the 27 incidents took place in the states of the North. In Benue State, Idoma farmers took revenge on Fulani cattle breeders for the alleged destruction of harvested farm products and pollution of water, while Tiv farmers allegedly collected N150,000 to allow

10 Uja, E. (2011), 18 Killed in Dawn Raid of Benue Comminities. The Nation. 15 February 2011, p. 3.

11 Joseph, H. (2012), 4 Killed in Renewed Farmers/Herders Feud in Nasarawa. Daily Trust. http://www.nigeriawatch.org/media/doc_acc/DT2012-02-17h_2.pdf. Accessed 14 October 2014.

12 O'Neil, S. (2012), Two Dead as Fulani, Indigenes Clash in Delta. The Nation. http://www.nigeriawatch.org/media/doc_acc/N2012-01-31p9.pdf. Accessed 14 October 2014. 
cattle to graze in violation of the law which had abolished such land tax, leading to violent clashes and the displacement of women and children from the community. ${ }^{13}$ In Kaduna, there was also a case of armed bandits killing soldiers and vigilantes during an early morning raid, with thousands of Fulani fleeing their residences in the aftermath. ${ }^{14}$

As at 31 May 2014, a total of 27 deaths were recorded for $2014^{15}$ from eight reported incidents in the months of January (Oyo and Abuja), February (Delta), March (Taraba, Benue, and Ebonyi) and May (Kaduna). The highest number of cases was in March (4), and the highest number of fatalities (10) was in Taraba, also in March. The major actors involved were armed gangs, the communities, and the army, the latter being reported to have perpetrated 'jungle justice' against some Fulani herdsmen who were accused of carrying weapons and who were summarily executed in Saminaka, southern Kaduna State. In contrast to the usual patterns of clashes between herdsmen and farmers, the soldiers were clearly identified as the aggressors by representatives of both groups (the chairman of the local government council and the president of MACBAN). ${ }^{16}$

\section{Cattle grazing and lethal violence in Nigeria:}

\section{A geographical analysis}

A geo-political analysis highlights that the ethno-religious identity of the actors engaged in cattle conflicts is quite significant. As shown in the graph and the maps (Figures 3.2, Map 3.1 and 3.2), northern Nigeria records the majority of fatal incidents (83 of 111), especially in Benue, Kaduna, Plateau, Kogi, Niger, and Nasarawa. These locations are mainly populated by the 'Middle Beltans', whose religious identity is often contrasted with that of Fulani Muslims.

13 Duru, P. (2013), Three Killed as Hedsmen, Idoma Farmers Clash. Vanguard. 28 January 2013, p. 7; http://www.nigeriawatch.org/media/doc acc/I2013-03-14.pdf. Accessed 9 October 2014

14 Sabiu, M. (2013), Blood, Tears in Zamfara, Kaduna: IGP Deploys Armed Policemen. Saturday Tribune. 22 June 2013 , p. 5.

15 This number had risen to 40 as at 31 August 2014 from a total of 12 recorded incidents.

16 Bashir, M. (2014), Soldiers Kill 6 Migrant Herders in Saminaka. Daily Trust. 23 May 2014, p. 8. 
Figure 3.2 Violent deaths caused by cattle grazing in Nigeria, by state, cumulated figures (June 2006-May 2014)

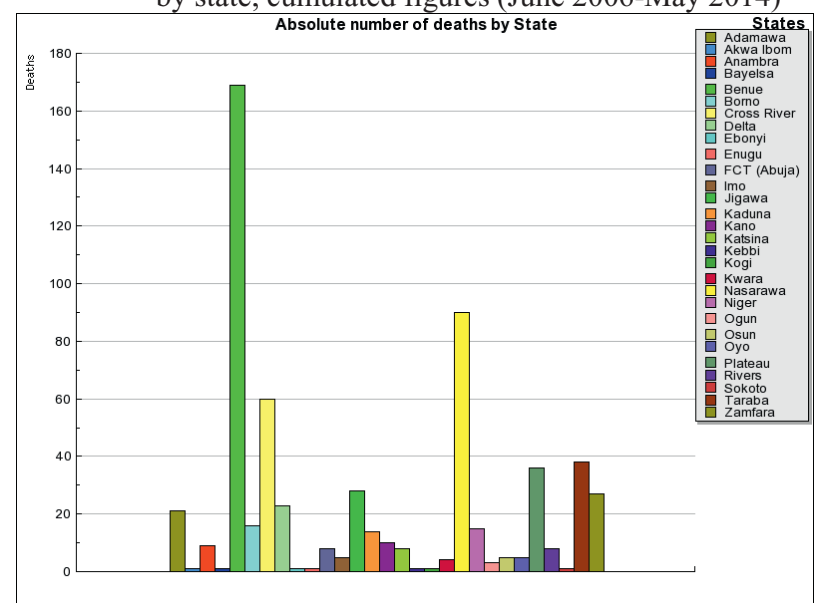

Map 3.1 Fatalities caused by cattle grazing in Nigeria (June 2006-May 2014)

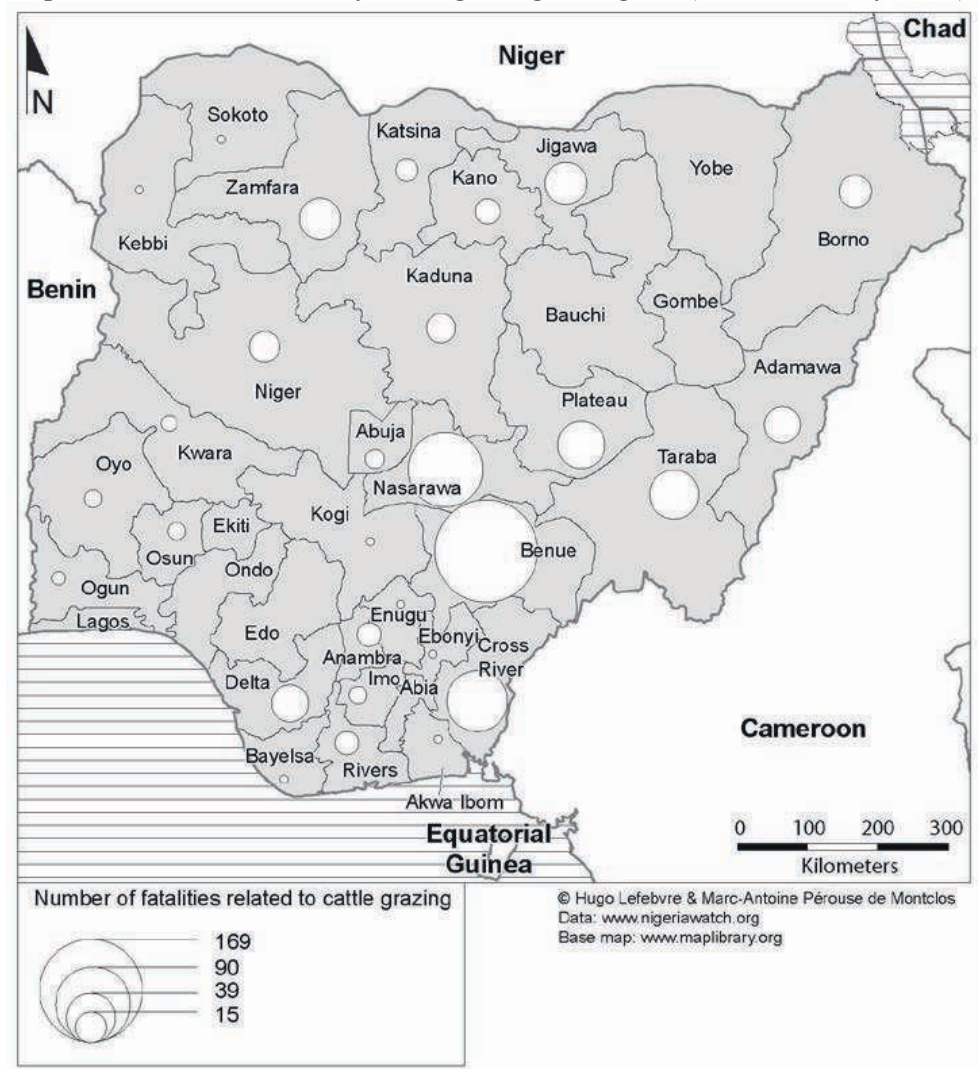


Map 3.2 Fatality rates caused by cattle grazing in Nigeria, per 100,000 inhabitants (June 2006-May 2014)

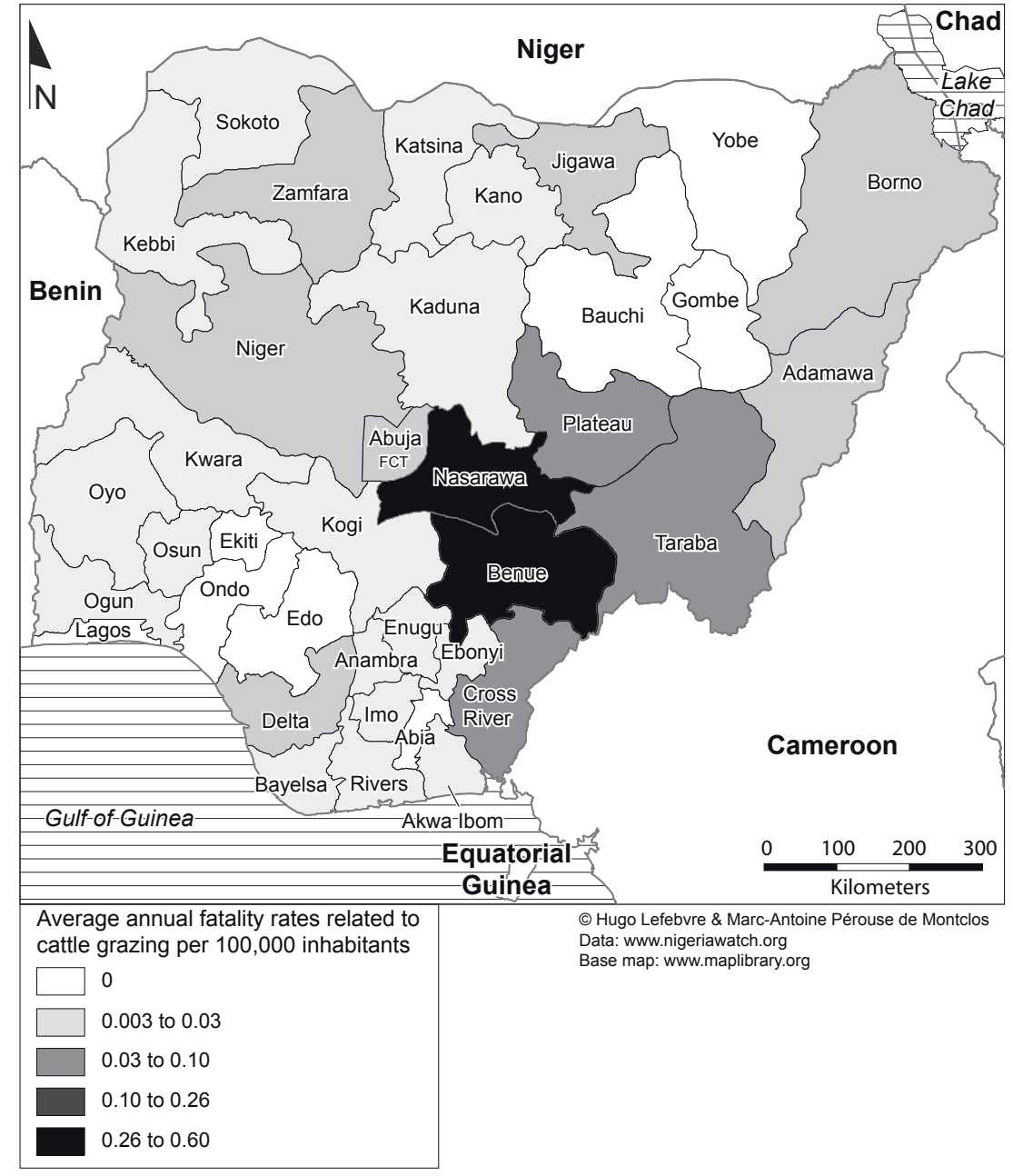

In the North Central region, both the Hausa and Fulani are associated with the Islamic oligarchy and the $1804 \mathrm{jihad}$, in contrast to the indigenes who are predominantly Christian and perceive themselves as being marginalized. Thus, in Benue in 2013, irate youths invaded and destroyed the Sabo market because its Hausa traders were considered the kith and kin of the Fulani herdsmen. In the same vein, the Benue State government reported the Fulani aggressors directly to the Sultan of Sokoto in 2011. Indeed, many people of the Middle Belt champion and perceive their political cause as a resistance to the Hausa/Fulani ethnic conglomerations of northern Nigeria. Even if there were no explicitly religious causes for the attacks, there is an underlying religion-based context of relationships 
which contributes much to the formation of opposing identities. This historical and ethno-religious dimension makes the stakeholders in cattle conflicts vulnerable to manipulation by politicians, both during elections and while these politicians are in office.

It is important, however, to note that in the North not every non-Hausa community is hostile towards the Fulani. In Kaduna State, for instance, the local government chairman of Saminaka proposed to petition the government on the misconduct of soldiers who extra-judicially killed six herdsmen. The context of the involvement of the security forces is indeed very multifarious. While they are sometimes portrayed as aggressors, they also suffer casualties in quite a number of cases, such as in Kaduna in 2013 when armed (purportedly Fulani) bandits killed soldiers alongside some vigilantes. The aftermath, which led to the fleeing of Fulani from the area, is indicative of the expected terror from the military in retaliation for their casualties. In this regard, the involvement of local vigilante groups as security alternatives is quite indicative of the loss of confidence in the state, as the police are said to be incompetent while soldiers allegedly arm assailants and provide them with uniforms for disguise. The border towns in Sokoto, Katsina, Kano, and Borno present a different case because they are easy entry points for foreign 'mercenaries', despite certain shared cultural and religious values between the stakeholders in violence.

In the South-South, it is also pertinent to note the high number of casualties reported in Cross River. If northern states like Jigawa, Adamawa, Borno, Taraba, Plateau, and Katsina recorded more fatal incidents, the case of the Ikpanaya community in 2012 shows how a local land dispute can easily degenerate into violence and extend to cattle issues. Engaged to attack another community, the Fulani herdsmen were secondary stakeholders in this crisis. Thus, the fatalities recorded in Cross River State were not directly linked with grazing activities. But the herdsmen indirectly protected their interests by supporting the indigenes who granted them access to the land in dispute in return for products from their animals. In addition, there was a religious angle to the crisis, with the destruction of churches by the invaders.

Whereas the South-South and the South East are predominantly Christian, such a scenario is very unlikely in the South West, where the Fulani are more assimilated. In the border towns of Ekiti, Oyo, and Osun, herdsmen are sometimes categorized as either 'Bororo' or 'Fulani Ilorin'; however, they are usually considered indigenes within the latter context. Moreover, among the Yoruba of the South West, it is not uncommon to observe siblings of different religious persuasion. This pluralism, together with a culture of tolerance, largely prevents the ethnoreligious manipulation of groups for political purposes, explaining the peaceful management of cattle conflicts between farmers and herdsmen in the region. 
Cattle grazing and lethal violence in Nigeria: A temporal analysis

Regarding the time frame nationwide, the data show that there has been an increase in the number of deaths and occurrences of lethal violence resulting from cattle grazing since 2006 (see Figure 3.1 above). More specifically, reported incidents significantly increased from 15 in 2011 to 27 in 2012, almost doubling the figures. The rising number of fatalities cannot be said to be directly connected to the sustained duration of the crises, as most of them did not last beyond a day, with a few exceptions in Katsina (eight days in 2008) and Adamawa (seven days in 2007). However, the increase in the number of casualties could be linked to the use of sophisticated weapons, which kill faster than the traditional Dane guns, machetes, spears, and arrows.

Figure 3.3 Violent deaths in Nigeria caused by cattle grazing, cumulative figures per month (June 2006-May 2014)

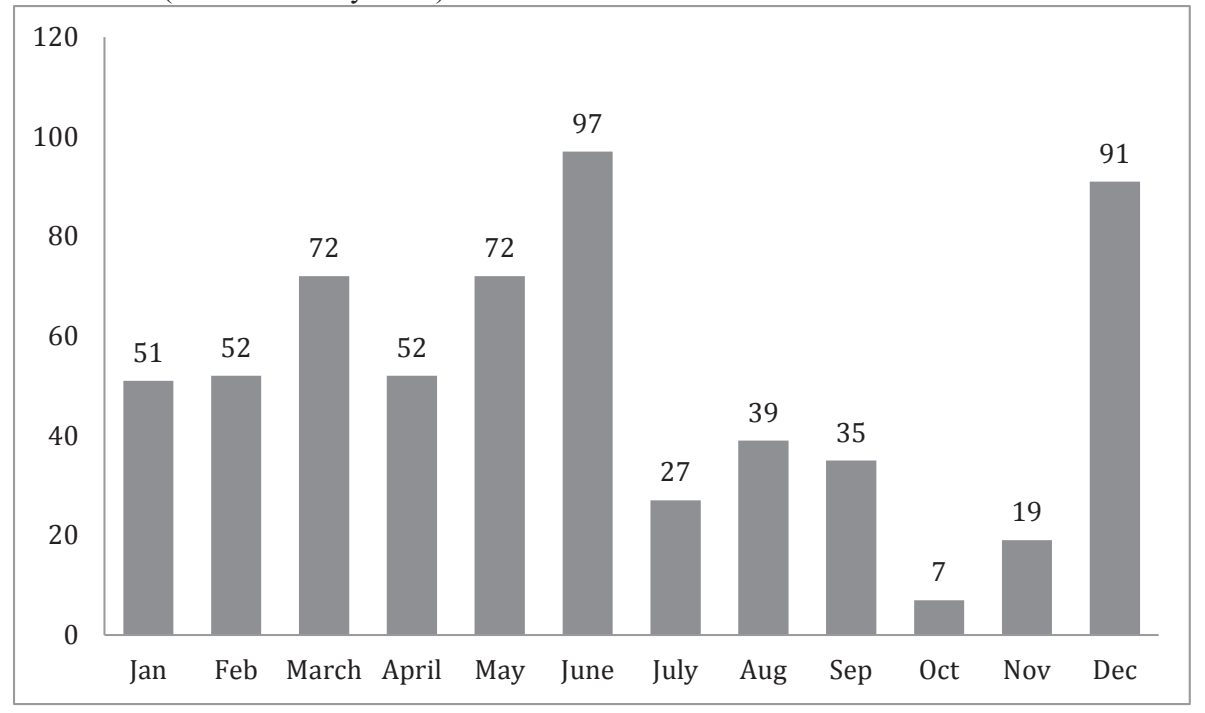

Figure 3.3 shows that the months of June and December have the highest number of casualties within the period being considered. Yet fatal cattle conflicts do not stop after the rainy season, as claimed by Adekunle and Adisa (2010) and Abbass (2012). The inference to be drawn from this is that there is no cycle of violence, perhaps because of the increasing sedentarization of the herdsmen. In fact, cattle conflicts do not necessarily involve seasonal movements in search of 
grazing lands; some of the conflicts result from reprisals during the night or at dawn in order to wreak havoc with minimal resistance. The mobilization of men disguised in army uniforms proves the premeditated readiness for these attacks. Sometimes, the problems are also related to the 'invasion' of border communities, as in Nasarawa in 2009, and may involve the engagement of foreign 'mercenaries' from the Republic of Niger, Chad, and Cameroon, as was reported in the case of the Mubi cow market in 2010.

\section{Conclusion}

This study has situated and analysed fatal incidents resulting from cattle grazing in Nigeria within its historical, political, and social contexts. Using the Nigeria Watch database data from June 2006 to May 2014, it has identified the major stakeholders as being communities of farmers and Fulani. State security agents, the political authorities, and local or foreign 'mercenaries' also played a role. The causes, however, were identified to be fundamentally economic and centred around land issues, showing that the creation by the government of grazing routes did not mitigate the problem. In the final analysis, the study revealed that violence from cattle conflicts was not restricted to specific periods of the year and occurred during all months, with the highest number of fatalities recorded in both the rainy (June) and dry (December) seasons.

\section{References}

ABBASS, I. (2012), No Retreat, No Surrender: Conflict for Survival Between the Fulani Pastoralist and Farmers in Northern Nigeria. European Scientific Journal 8(1): 331-346.

AdAms, A., ed., (2014), Fatality Trends. The Nigeria Watch Project 1(2). (January-April).

AdeKunle, O. \& S. AdisA (2010), An Empirical Phenomenological Psychological Study of Farmer-Herdsmen Conflicts in North-Central Nigeria. Journal of Alternative Perspectives in the Social Sciences 2(1): 1-27.

Audu, S. (2013), Conflicts Among Farmers and Pastoralists in Northern Nigeria Induced by Freshwater Scarcity. Developing Country Studies 3(12): 25-32.

Audu, S. (2014), Freshwater Scarcity: A Threat to Peaceful Co-Existence Between Farmers and Pastoralists in Northern Nigeria. International Journal of Development and Sustainability 3(1): 242-251.

Awogbade, M. (1987), Grazing Reserves in Nigeria. Nomadic Peoples 23: 19-30.

AZARYA, V. (1996), Pastoralism and the State in Africa: Marginality or Incorporation. Nomadic Peoples 38: 11-36.

Bello, A. (2013), Herdsmen and Farmers' Conflicts in North-Eastern Nigeria: Causes, Repercussions and Resolutions. Academic Journal of Interdisciplinary Studies 2(5): 129-139.

BlenCH, R. (1994), The Expansion and Adaptation of Fulbe Pastoralism to Subhumid and Humid Conditions in Nigeria. Cahiers d'etudes africaines 34(133-135): 197-212. 
Blench, R. (2010), Conflict Between Pastoralists and Cultivators in Nigeria. Review paper prepared for DFID, Nigeria. 9 August 2010.

BOURN, D. (1992), Highlights of the Nigerian Livestock Resources Report. www.odi.org/resources/docs/5399.pdf. Accessed 5 October 2014.

BRADBURD, D. (1996), Towards the Understanding of the Fate of Modern Pastoralists: Starting with the State. Nomadic Peoples 38: 37-48.

Braukamper, U. (1996), Strategies of Environmental Adaptation and Patterns of the Transhumance of the Shuwa Arabs in Nigerian Chad Basin. Nomadic Peoples 39: 53-68.

Dyson-Hudson, R. (1990), Towards a General Theory of Pastoralism and Social Stratification. Nomadic Peoples 7: 1-7.

Fasona, M. \& A. Omojola (2005), Climate Change, Human Security and Communal Clashes in Nigeria. Paper presented at the International Workshop on Human Security and Climate change, Holmen Fjord Hotel, Oslo, 21-23 October 2005.

Folami, O. (2009), Climate Change and Inter-Ethnic Conflict Between Fulani Herdsmen and Host Communities in Nigeria. A Paper Presented at Conference on Climate Change and Security Organized by the Norwegian Academic of Sciences and Letters on the Occasion of 250 Years' Anniversary in Trondiem, Norway 2010.

GeFu, J. \& J. Gilles (1990), Pastoralists, Ranchers and the State in Nigeria and North America: A Comparative Analysis. Nomadic Peoples 25-27: 34-50.

IRO, I. (1994), The Fulani Herding System. Washington: African Development Foundation.

Koster, H. \& J. DE WolfF (2012), Dairy Development Programme in Nigeria Baseline Report: Key Findings and Recommendations. Alabama: IFRC.

Krause, J. (2011), A Deadly Cycle: Ethno-Religious Conflicts in Jos, Plateau State, Nigeria. Working Paper. Geneva: Geneva Declaration Secretariat.

MANU, I.N., W.N. ANDU, D.N. TARLa \& W.N. AghariH (2014), Socio-Economic Effect of Cattle Theft on the Pastoralists of the North West Region of Cameroon. Scholarly Journal of Agricultural Science 4(6): 299-305.

MCGREgor, A. (2014), Alleged Connection Between Boko Haram and Nigeria's Fulani Herdsmen Could Spark a Nigerian Civil War. Terrorism Monitor 12(10): 8-10 (16 May).

OdoH, S. \& C. ChigOzIE (2012), Climate Change and Conflict in Nigeria: A Theoretical and Empirical Examination of the Worsening Incidence of Conflict between Fulani Herdsmen and Farmers in Northern Nigeria. Arabian Journal of Business and Management Review 2(1): 110-124.

OfuOKU, A. \& B. ISIFE (2009), Causes, Effects and Resolution of Farmers-Nomadic Cattle Herders' Conflict in Delta State, Nigeria. International Journal of Sociology and Anthropology 1(2): 47-54.

OKello, A.L., A.O. MajeKodunmi, A. Malala, S.C. WelbuRn \& J. Smith (2014), Identifying Motivators for State-Pastoralist Dialogue: Exploring the Relationships Between Livestock Services, Self-Organisation and Conflict in Nigeria's Pastoralist Fulani. Pastoralism: Research, Policy and Practice 4(12): 1-14.

Olabode, A. \& L. AJiBADE (2010), Environment Induced Conflict and Sustainable Development: A Case of Fulani-Farmers' Conflict in Oke-Ero LGAS, Kwara State, Nigeria. Journal of Sustainable Development in Africa 12(5): 259-273.

SELlEn, D. (1996), Nutritional Status of Sub-Saharan African Pastoralists: A Review of the Literature. Nomadic Peoples 39: 107-134.

SHEHU, D. \& W. HASsan (1995), Women in Dairying in the African Savannah: Their Contribution to Agro-Pastoral Household Income in the Dry North-West of Nigeria. Nomadic Peoples 36/37: 53-64. 
SolagBerU, R. (2012), Land Use Conflict between Farmers and Herdsmen: Implications for Agricultural and Rural Development in Nigeria. In: R. Solagberu, ed., Rural Development: Contemporary Issues and Practices. Rijeka/Shanghai: In Tech, pp. 99-118. 


\title{
Trends and patterns of fatalities resulting from cult societies and belief in witchcraft in Nigeria (2006-2014)
}

\author{
Akinpelu Babajide Adedotun
}

\begin{abstract}
As a result of the voracious appetite and interest of the average Nigerian in anything metaphysical, the media tend to over-sensationalize the issues of witchcraft and cult societies. Religious bodies also tend to overemphasize sorcery as a major source of misfortune and poverty, creating fear in the hearts of the common man. Relying on the Nigeria Watch database data recorded since 1 June 2006, however, this study reveals that witchcraft accounted for only 661 violent deaths in the last eight years, or $1 \%$ of the total number of fatalities reported during the period under review. Moreover, most deaths attributed to sorcery occurred in the southern part of the country. The same pattern applies to cult societies, thereby illustrating a difference between the South and the North. In the North, eight states did not experience any ritual killings in the last eight years. Though the belief that politics is related to cult societies is strong, the number of violent incidences leading to deaths is low. Therefore, evidence of such a relationship remains vague and unproven.
\end{abstract}

\section{Introduction}

Nigerian newspapers report almost daily on incidences of witchcraft and occult activities. The aim of this research is thus to analyse the trends and patterns in which violent deaths attributed to sorcery and cultism occur in the country. The purpose is not to argue for or against the existence of occult powers. The research uses scientific and statistical description to shed light on the phenomena of witchcraft and cult societies according to the available data of the Nigeria Watch project, which has collected data since June 2006.

The paper is divided into three parts. The next section provides a historical perspective of witchcraft and cult societies in the Nigerian political, economic, 
and social context. The succeeding section provides data on locations where occurrences of ritual killings abound and explains why they are more prevalent in some parts of Nigeria. The last section analyses the role cult groups play in politics. As shown by the available data, political issues rank high in the causes of violent deaths involving cult societies. Further findings are discussed before a conclusion is drawn.

\section{African belief in witchcraft and cult societies: The Nigerian view}

An appropriate point to begin with is a definition of witchcraft. According to the Encyclopedia Britannica, witchcraft is 'the exercise or invocation of supernatural powers to control people or events, typically involving sorcery or magic'. It is often associated with human beings who meet secretly in the night, indulge in cannibalism and wickedness, organize rites and rituals with 'the Devil', and perform black magic. Witchcraft is a global phenomenon that has existed for centuries in nearly all societies of the world.

According to Okon (2012):

Witchcraft is a constant problem in Africa. Africans of all classes, poor and rich, illiterates and the educated classes, all have one or two bad experiences to say about witchcraft as a nefarious and destructive spirit that is hindering human and social development in the continent. [...] Africans have unconsciously developed witchcraft mentality - which is a permanent condition of living helplessly in fear, intimidation, mental torture and spiritual insecurity. Witchcraft has not only weakened the social bond, but it has forced the African to embrace pseudo spirituality and diabolic religious rituals. Spiritual vigilance and protection against witchcraft attack has become a vital aspect of socialization in Africa. The average African child grows with the fear of witchcraft.

Although the belief in sorcery predates colonial rule and interaction with Western civilization, new forms of cult groups have emerged in the face of urbanization. Violence by and against alleged witches represents but one aspect of a multifarious urban insecurity. Witchcraft today is also commoditized. It is a product on the market, whose power is increased through human sacrifices and reduced through 'deliverance'. The modern witch is, in microeconomic terms, a rational economic agent motivated by non-satiation and greed (Essia 2012). Thus, the commercial distribution of human body parts involves sophisticated networks and relies on 'abattoirs' such as the 'Ibadan house of horrors', which was discovered in March 2014. Another contemporary dimension to the issue of witchcraft can be found in the new Evangelical and Pentecostal churches, which generally depict godliness and success in terms of overcoming the Devil. These movements have popularized the thinking that material fortune is universally available, but access to it is inhibited by the Devil, and all it takes to appropriate success is to get witches out of the way (ibid.). 


\section{Political context of witchcraft and cult societies}

Secret cult groups often interact with politics, although they are openly outlawed by Nigeria's 1999 Constitution. Scholars refer to the fact that cult societies already played important roles in the governance of pre-colonial Nigeria, especially with the Ibo and the Yoruba in the South (Ellis 2008; Okunola \& Ojo 2012). No such influence seems to have developed under the emirate system in the North. However, Olurode's (1990) work on the Nupe people of Bida shows that cult societies existed in some parts of the North. In the South, the influence of such occult groups was somewhat retained under colonial indirect rule, despite the introduction of new religion and a Western form of governance. For the British, indigenous institutions could be allowed to function inasmuch as they gave prestige and support to the Native Authorities, which were the key organs of indirect rule. In the southern part of the country, however, the colonial administration introduced artificial warrant chiefs and destroyed some shrines.

It was the half-tolerance, half-suppression, of older systems of governance that made Indirect Rule so thoroughly ambiguous, the official organs of Indirect Rule being shadowed by institutions such as shrines whose actual powers often exceeded those they were officially deemed to have. (Ellis 2008)

The influence of cultism and witchcraft could also be felt in the creation of political parties right from their inception. Indeed, the nationalist movement interacted with indigenous religious institutions and initiation societies in Nigeria's eastern and western regions. Moreover, secrecy and hidden powers were used to provide a form of legitimacy and protection for politicians with influence. After independence, for instance, military leaders were also reported to have kept an arsenal of sorcerers, fortune-tellers, and Islamic marabouts around them. This shows that the belief in sorcery has overshadowed every form of government in Nigeria, be it civilian rule or military dictatorship. Modern and traditional rulers alike have had to understand and speak the language of ritual violence to guarantee their power in the state.

\section{Economic context of witchcraft and cult societies}

The economic context also plays a role. Belief in witchcraft shapes perceptions and provides an answer to the question 'Why me?' when misfortune strikes:

Unexpected hardship or bad luck, sudden and incurable diseases, all can be accounted to the actions of evil people; to magical forces the diagnosis of witchcraft opens up the possibility of combating the causes of hardship. (Schnoebelen 2009)

Witchcraft beliefs satisfy a deeply rooted desire to be sure that the world is concerned with us, our fate, and our happiness, and that nothing happens simply by chance. The acceptance of a domain of life where malevolent forces, like the 
witch, can be defined and attacked makes it possible to bear a universe devoid of such design.

Despite its oil wealth, Nigeria still ranks among the poorest in the world on the basis of per capita income. The country has witnessed a plundering of her wealth by its leaders: Nigerian office holders are considered among the most flamboyant in the world. The cult groups have profited from the patronage of these corrupt leaders. In his analysis of the patrons of the Okija shrine, for instance, Ellis (2008) observed that the cult industry remains very lucrative even in contemporary times:

Analysis of the names indicated that most patrons were from the southeast of the country and
that they included doctors, lawyers, engineers, politicians and company directors. Some of
these litigants were reported to have paid very large sums, even hundreds of thousands of
naira, the equivalent of thousands of dollars, to the chief priest of Okija. Contrary to priests'
claims that the fees were paltry, the lowest recorded payment was 5,000 naira ( $\$ 38$ at 2004
values). The highest payment recorded was over 100 times that amount. The Anambra State
police commissioner, Felix Ogbaudu, who led the 2004 raid on the Okija shrine, stated that
he knew of one person who claimed to have paid 800,000 naira $(\$ 6,070)$. Moreover, litigants
who subsequently died, and whose corpses were brought by their families to the forest, had
their goods confiscated by the shrine. This meant that very considerable amounts of money
were involved in the shrine's affairs.

Scholars have also argued that the proliferation of local cult groups is evidence of economic discontent by disaffected youth. This can be said to be the case in the Niger Delta, a region known for its oil wealth. The paradox of penury in the midst of plenty has exacerbated grievances, prompting local resistance and rebellion in which militia and cult groups have been critical actors, especially since the 1990s (Nyiayaana 2011). Thus, membership of cult groups has economic underpinning, yet is sometimes open to a specific class of people: the rich and influential. As observed by Elegbeleye (2005) and Egbochuku (2009) all over southern Nigeria, for instance, university cult societies include children of the higher strata of society.

The economic dimension of witchcraft can also be linked to urbanization and modernity. When considering reported cases of penis snatching or ritual killing for money, witchcraft seems to have evolved from the kinship stage to a new stage of anonymity in large cities.

Penis snatching, deadly alms and killer phone numbers all illustrate the dangers of anonymity. Anonymity stands out clearly as the most distinctive common denominator of these new forms of the occult, especially if contrasted with 'family witchcraft', which represents the archetypal form of witchcraft. (Bonhomme 2012)

Many Nigerians have left their rural villages, coming to modern cities such as Lagos and Abuja in search of greener pastures. In these cities, they realize that the grass is much greener at home, yet they cannot return to the village emptyhanded. Thus, they resort to blaming witchcraft for their economic woes. Also, 
anyone successful in business or education is believed to be involved in one form of sorcery or another. His/her wealth is due to ritual killing or to the use of body parts for money rituals. According to Korhnet (1996), for instance:

Witchcraft accusations with a strong liberating, emancipative or egalitarian impetus are directed against enemies within their own community. Examples are witchcraft accusations directed against rich peasants and traders in East and West Africa, who accumulate large sums of grain or money individually, without due regard to their obligation - under the traditional solidarity-system of the village community - to assist the poor in case of hardship.

\section{Social dimension of witchcraft and cult societies}

Rooted in spirituality and religious practices, secret cult groups are not a new phenomenon in African social formations. Traditionally, they provided mechanisms and structures that defined the role and relationships of each member. They not only served the spiritual and social needs of their members, but also acted as institutions for social control through the execution of traditional customs, settlement of disputes, and the dispensation of justice (Offiong 1984). Furthermore, membership of a cult group was restricted to adults and represented an elevated status in traditional African society.

In Nigeria, cult groups were ethnically based. Accordingly, the Reformed Ogboni Fraternity, Ekpo, Okija Shrine, Amanikpo, and the Igbe secret cult groups, among others, have been found among the Yoruba, the Efik, the Igbo, the Ogoni, and the Isoko peoples of the south-western and south-eastern parts of Nigeria (Ellis 2001). At the same time, new forms of cult groups, the Pyrate confraternity, Panama, and Black Eye have also emerged as a response to changing social, political, and economic realities in Nigeria. These cults initially functioned as civil society organizations but were later factionalized and transformed into violent groups (Nyiayaana 2011).

Just as cult groups were a source of control in pre-colonial African society, the same can be said of witchcraft. Stenberg (2010) asserted that "witchcraft operated, simultaneously, as a moral narrative and means of behavioural enforcement which facilitated social control, and maintained and restored damaged social orders'. Belief in witchcraft has shown resilience to change and, instead of dying out, has evolved to face new situations in contemporary life. People have often resorted to cult societies because they lacked effective mechanisms to resolve conflicts. Having no access to independent central powers meant that any groups that got involved in a conflict were also burdened with the task of resolving that conflict among themselves (Harnischfeger 2006). Under such circumstances, the determination to have an oracle decide matters may have been the best means of keeping or building peace. Thus, thousands of people in search of justice once came from all over Igboland to the famous shrine of Arochukwu in order to have 
their disputes settled there. For Westerners it is frightening to imagine that decisions of life or death should depend on such methods. For many Igbo, however, it is reassuring to know that judgment is rendered by alien, invisible powers, not by one's fellow humans, as human authority is scarcely to be trusted.

\section{Witchcraft, cult societies and violent deaths in Nigeria since 2006}

Nowadays, witchcraft and sorcery account for a relatively small number of violent deaths in Nigeria (Figure 1.2). The Nigeria Watch database recorded over 61,000 violent deaths during the period under investigation, from June 2006 to May 2014. Crime and car accidents remain the major causes of fatalities, followed by political and religious conflicts. Despite many legends of bloodsucking witches killing thousands, sorcery accounted for only 661 deaths, which represents just $1 \%$ of violent deaths reported. Yet the Nigeria Watch database records fatalities only and does not cover all the aspects of witchcraft. For instance, the press reports many cases of mutilated bodies where the violent cause of the death is not proven and hence not recorded.

A look at the protagonists involved in lethal violence confirms that sorcery does not constitute an overarching cause of fatalities in Nigeria. Figure 4.1 shows that cult societies accounted for 1,863 deaths between 1 June 2006 and 31 May 2014. These figures seem low when compared with other protagonists, such as armed gangs, political groups, and the police. However, women and children account for an important proportion of the victims, even if men and adults still represent the majority (Tables $4.1 \& 4.2$ ).

Table 4.1 Number of male and female victims killed because of the belief in sorcery, Nigeria (June 2006-May 2014)

\begin{tabular}{lcccc}
\hline & Male & Female & Undetermined & Total \\
\hline Number & 206 & 170 & 396 & 772 \\
Percentage & $26.7 \%$ & $22 \%$ & $51.3 \%$ & $100 \%$ \\
\hline
\end{tabular}

Table 4.2 Number of adults and children killed because of the belief in sorcery, Nigeria (June 2006-May 2014)

\begin{tabular}{lcccc}
\hline & Adult & Children & Undetermined & Total \\
\hline Number & 274 & 123 & 375 & 772 \\
Percentage & $35.5 \%$ & $15.9 \%$ & $48.6 \%$ & $100 \%$ \\
\hline
\end{tabular}

Note: The total number in the tables above is slightly different from the number in Figures 1.2 and 4.1 because it is based on actual texts of newspaper reports, while the Nigeria Watch database records averages according to different sources for each incident. 
Figure 4.1 Number of violent deaths in Nigeria, by protagonist, cumulated figures (June 2006-May 2014)

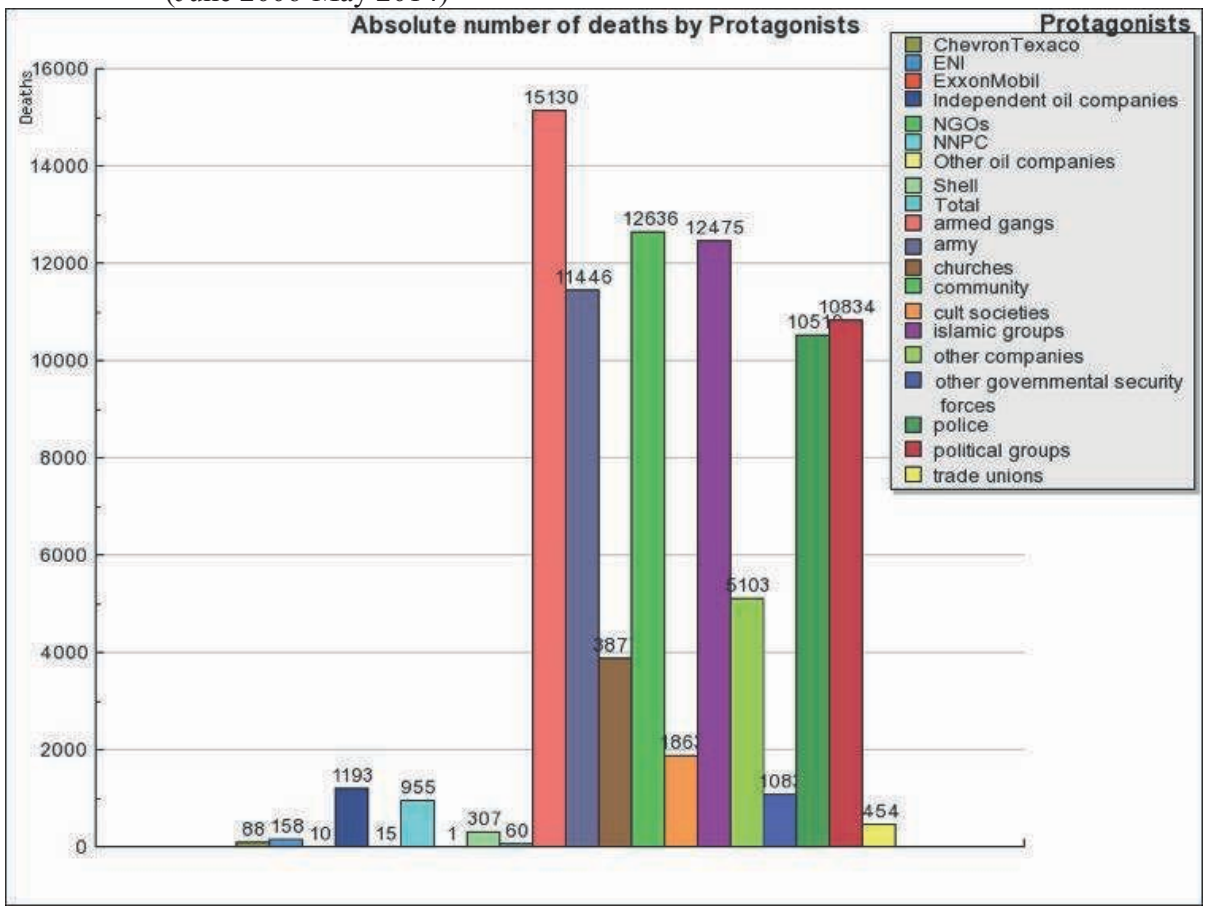

\section{A mapping of witchcraft and ritual killings in Nigeria}

In trying to track the prevalence of witchcraft in Nigeria, available data also show a high prevalence in the southern part of the country compared with the northern part. States like Yobe and Sokoto experienced no occurrence of fatalities resulting from witchcraft, while the other northern states recorded less than five in the last eight years, except for Borno, where newspapers reported 44 deaths involving mutilation of body parts and credited these deaths to the Boko Haram insurgents (Map 4.1).

In the South, Lagos witnessed the highest number of sorcery-related deaths (89), followed closely by Delta (84). In terms of frequency, Lagos also recorded more cases of ritual killings than in any other state, with 59 incidences in eight years. However, compared with its population, Delta State had a relatively higher number of such deaths, with a rate of 1.9 per 100,000 inhabitants, as against 0.8 in Lagos. Delta State was followed by Abia (1.7) and Kwara, which had the highest prevalence in the North, except for the special case of Borno because of the Boko Haram insurgency. The pattern of Kwara may be due to its location as a link between the southern and northern parts of Nigeria. 
Map 4.1 Fatality rates caused by sorcery in Nigeria, per 100,000 inhabitants (June 2006-May 2014)

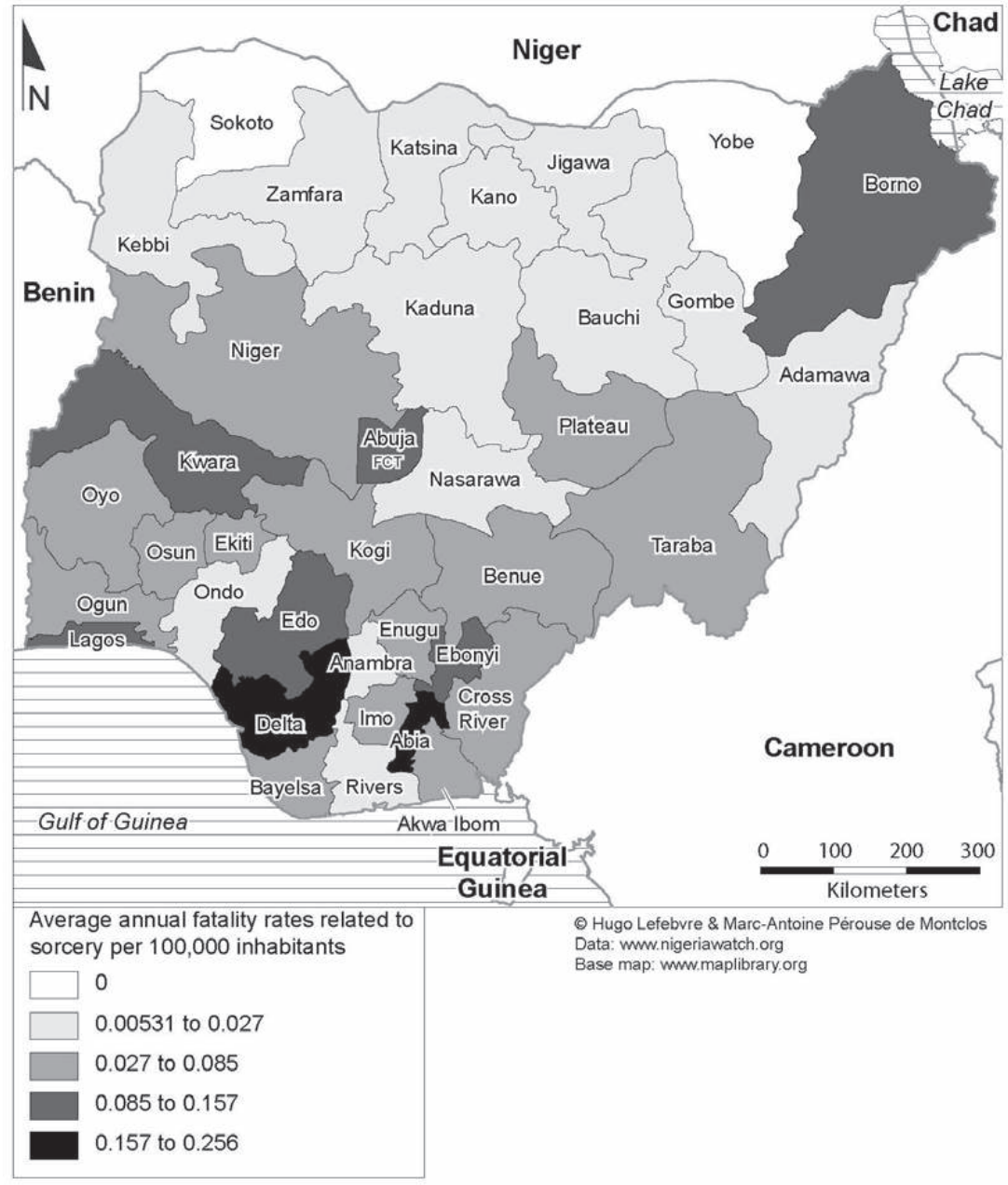

In Lagos, the high prevalence of ritual killings can be attributed to the fact that the state is the commercial nerve centre of the country, a situation which exacerbates the belief in money rituals. The reported case of a multi-millionaire Pentecostal pastor involved in a case of ritual killing supports this argument. According to the press:

The General Overseer of a fast-growing pentecostal church in Lagos has been arrested by the Police for alleged ritual murder. The pastor simply identified as Fireman has been detained at the State Criminal Investigation Department (SCID), Panti, Yaba, Lagos following alleged confessional statement of an 18-year-old boy, Ikechukwu, who was caught strangulating a 12-year-old girl identified as Bose. 
Okechuku had told the Police that the Pastor had contracted him to kill a female virgin and bring her faeces for a N100,000 fee. The pastor was arrested after five days on the run. Ikechukwu, who was paraded at SCID, Panti by the state Police spokeswoman, Ngozi Braide, narrated how he strangulated the girl.

'I started attending the church in Surulere since 2011 when I heard how the man of God was performing miracles and I believed in the pastor. After Christmas celebration, I was ashamed that I had nothing for the New Year celebration, especially clothes. The spirit moved me to approach my pastor for help and when I met with him, he promised to give me N100,000 if I could get the faeces of a strangled virgin.

'I agreed to get the faeces of a virgin. I remembered a food vendor's daughter, who I suspected was a virgin and I went to the woman's shed at Badagry. When I met Bose, I bought rice and plantain from her. She served me and after eating, I lured her to an uncompleted building on the pretense that I wanted to show her something. Immediately we entered the building, I held Bose on the throat until she defecated and died. I wanted to pack the faeces when I heard the shout of a man calling for my arrest and I tried to escape but I was arrested by some people.

'They wanted to kill me but a man begged that I should be spared so that I can be used as witness against the pastor. I thank God that my life was saved because the pastor would have denied that he sent me.'

Police spokeswoman, Ngozi Braide, said the pastor has been arrested after many days of being on the run. She said that though the case was being investigated, Ikechukwu had made confessional statement that the pastor sent him.

She said the pastor was being interrogated by detectives after which the police would determine the fact of the matter. (Oji 2014)

Another explanation for the higher prevalence of ritual killings in the southern part of Nigeria can be found in history. In Lagos, the first church was established in Badagry in 1842, while Islam was already well developed in the North before finding its way to the South. As we observed in our data, Sokoto State, revered as the seat of the caliphate, reported no case of violent deaths attributed to sorcery in the period under examination. Meanwhile, in the South, the indirect rule introduced by the British colonialists relied on some traditional structures that used to practise human sacrifice.

As shown in Map 4.1 and Figure 4.2, Rivers State, for instance, recorded the highest prevalence of cult killings per state in the last eight years. This was due to the activities of local cult societies and their frequent clashes with rival gangs and security forces. In fact, all the states in the South recorded at least one case of cult society killing. By contrast, eight northern states reported no cases of cult killing in the years under review. However, the LGA that suffered the highest number of fatalities related to cult activities (205), Lafia in Nasarawa State, was in the North. This is due to the emergence of a new cult group, Ombatse (lit. 'time has come'), that claims to heal the region from corruption and poverty. The administration of Nasarawa State actually saw the group as a political movement of opponents, and many people were killed in a clash with security agents in May 2013. 
Figure 4.2 Number of violent deaths in events where cult societies were involved, by state, cumulated figures (June 2006-May 2014)

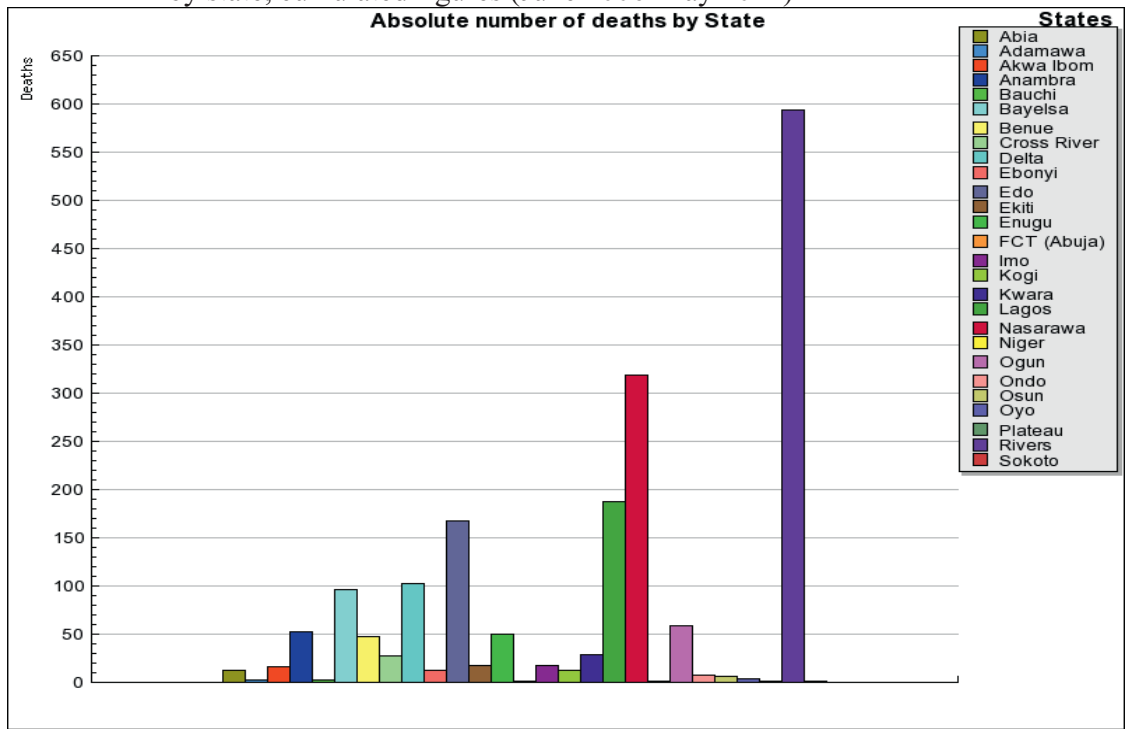

\section{Links with politics}

Cult activities often have political underpinnings. A total of 307 deaths attributed to cult groups were politically motivated in five states in the last eight years, as shown in Figure 4.3.

Figure 4.3 Violent deaths caused by political issues in events where cult societies were involved (June 2006-May 2014)

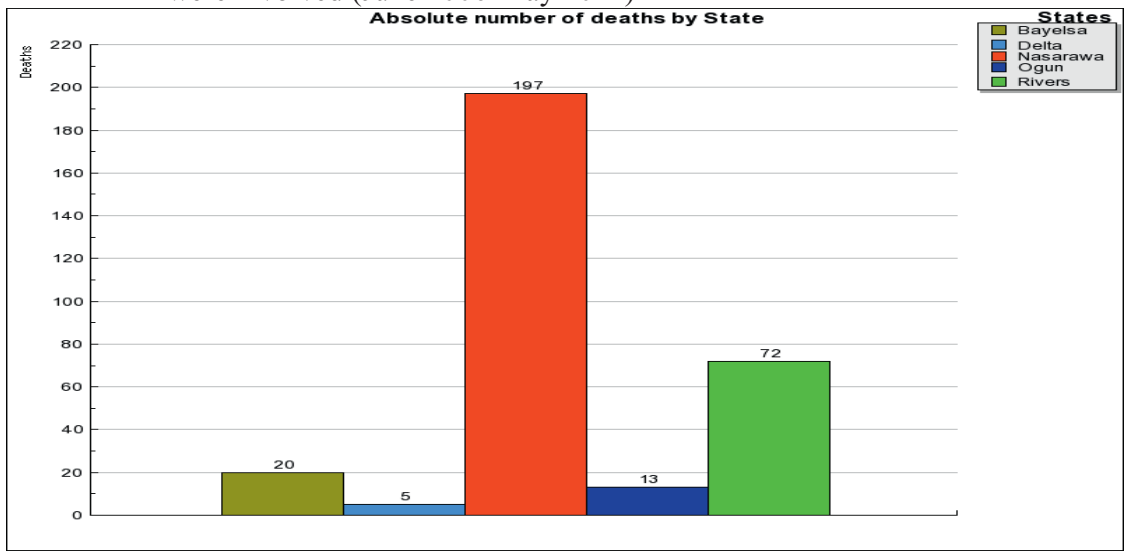


The situation in these areas is actually quite complex:

Cult gangs are active within community youth associations as enforcers, to defend the interests of their members, increase their influence and for protection [...]. Cults have served as a gateway into all kinds of criminality and violence, including militancy [...]. These groups and networks of groups had wide geographical penetration and were heavily armed. But further complicating the structure is the fact that many youth associations at the community level also have 'cult groups', some of which take their names from the larger organizations with whom they may or may not have direct or indirect linkages. So the entanglements and overlap between university confraternities, street gangs, youth groups, and ethno-nationalist militias are not easily unraveled. (UNLock Nigeria 2012: 9)

Nationwide, no significant correlation seems to exist between witchcraft and cult society fatalities and election years in 2007 and 2011 (Figures 4.4, 4.5 and Map 4.2). Although there is a steady climb yearly in violent deaths related to political issues because of the Boko Haram crisis in the North-East, there was no visible increase in the number of fatalities attributed to sorcery in 2011, an election year. However, the trend seems to be on the increase, especially for the year 2013 and the first five months of 2014 (Figures 4.4 and 4.5).

Figure 4.4 Number of violent deaths in Nigeria caused by sorcery, per year (June 2006-May 2014)

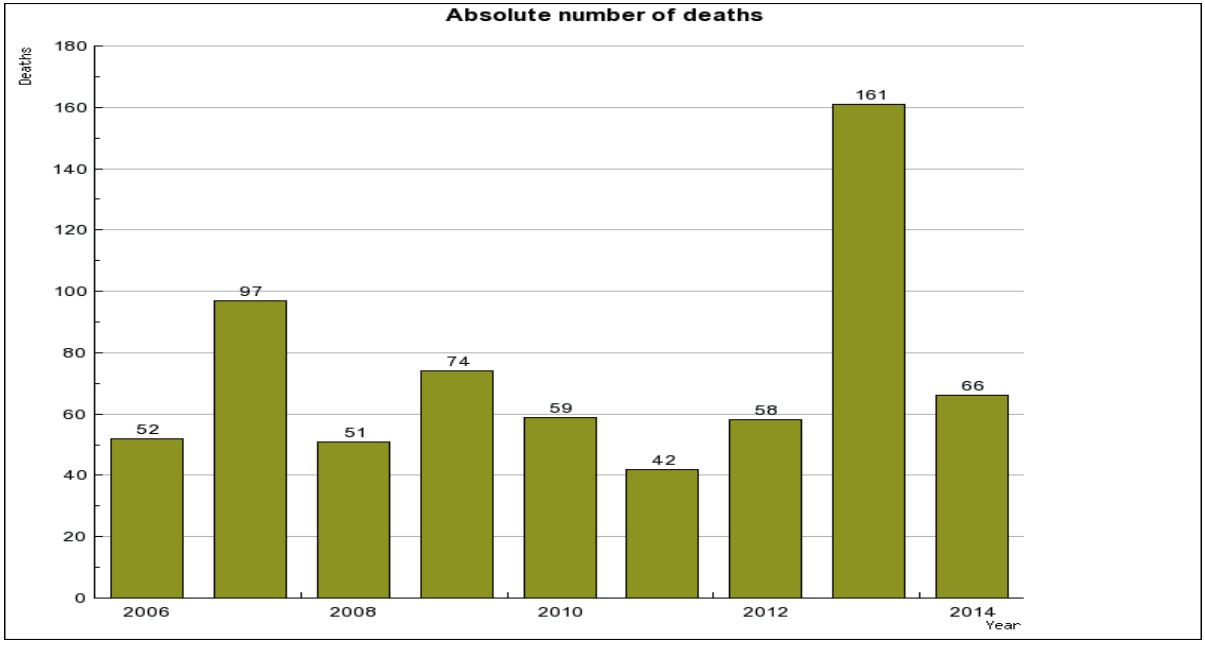


Map 4.2 Fatalities in events where cult societies were involved in Nigeria (June 2006-May 2014)

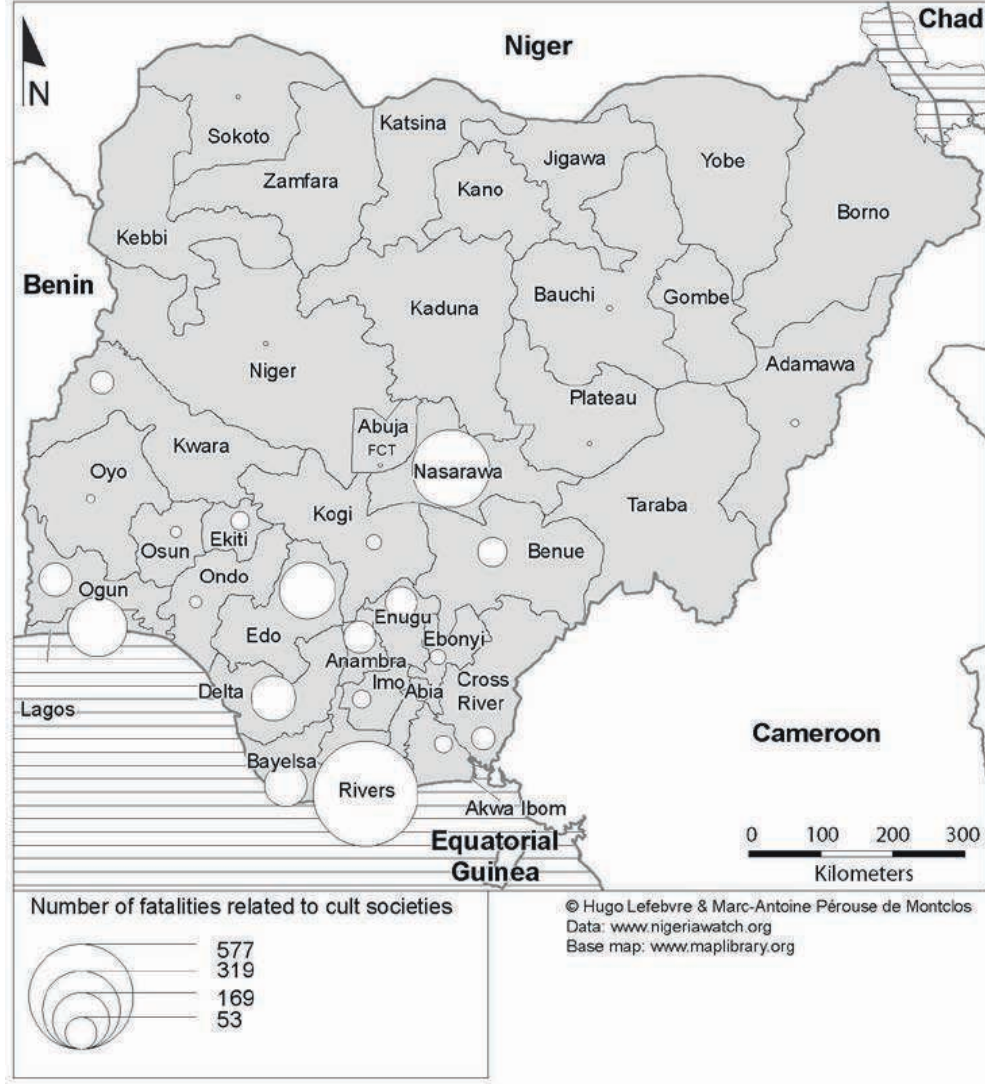

Figure 4.5 Number of violent deaths caused by political issues, per year (June 2006-May 2014)

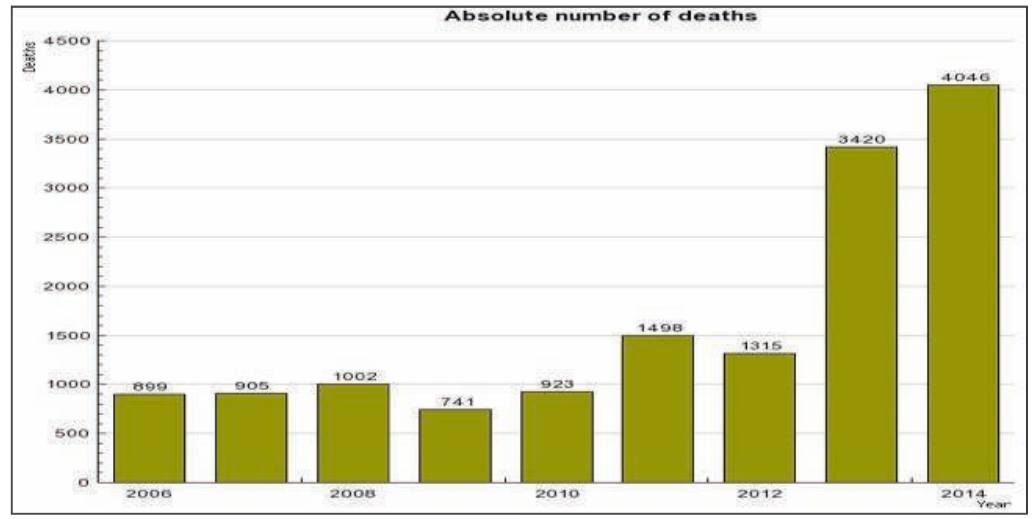




\section{Conclusion}

Although the media has been accused of fuelling the belief in witchcraft and cults, fatal cases reported by newspapers are as real as the threat associated with witchcraft in the mind of the African. The Nigeria Watch database shows that witchcraft-related violence is more prevalent in the southern than in the northern part of Nigeria. The main reason for this can be found in the history, traditions, and culture of these areas, and in the introduction to a foreign monotheistic religion, which occurred earlier in the North than in the South. In the case of cult killings, fatalities and incidents are highest in Rivers State. Although cult-related killings are also to be found in Nasarawa, Kwara, and Benue states, eight northern states were totally free of the problem, while in the South, all the states recorded at least one incidence of cult killing. However, empirical evidence connecting witchcraft and cult societies to violent deaths is low compared with the widespread belief in occult phenomena.

\section{References}

Bonhomme, J. (2012), The Dangers of Anonymity: Witchcraft, Rumor, and Modernity in Africa. HAU: Journal of Ethnographic Theory 2(2): 205-233.

CieKawy, D. \& P. Geschiere (1998), Containing Witchcraft: Conflicting Scenarios in Postcolonial Africa. African Studies Review 41(3): 1-14.

EgBochuKu, E. (2009), Secret Cult Activities in Institutions of Higher Learning: Lessons from the Nigerian Situations. Studies of Tribes and Tribals 7(1): 17-25.

Elegbeleye, O. (2005), Personality Dimension to University Campus Cult Membership. Anthropologist 7(2): 129.

ELLIS, S. (2008), The Okija Shrine: Death and Life in Nigerian Politics. The Journal of African History 49(3): 445-466.

EssiA, U. (2012), The Social Economy of Child Witch Labeling in Nigeria: The Case of Akwa Ibom State. Science Journal of Psychology, Article ID sjpsych-289, 11 pp. Available at: http://www.sjpub.org/sjpsych/sjpsych-289.pdf. Accessed on 3 December 2014.

HaRnischfeger, J. (2006), State Decline and the Return of Occult Powers: The Case of Prophet Eddy in Nigeria. Magic, Ritual, and Witchcraft 1(1): 56-78. University of Pennsylvania Press.

IFEKA, C. \& E. FlOWER (1997), Capturing the Global: Identities, Kinship, and Witchcraft Trials in Boki Society, Nigeria.

KOHNERT, D. (1996), Magic and Witchcraft: Implication for Democratization and PovertyAlleviating Aid in Africa. World Development 24(8): 1347-1355.

KoHnert, D. (2007), On the Articulation of Witchcraft and Modes of Production Among the Nupe, Northern Nigeria, GIGA-German Institute of Global and Area Studies / Institute of African Affairs.

NYIAYAANA, K. (2011), From University Campuses to Villages: A Study of Grassroots-based Cult Violence in Ogoniland. ERAS 12(2), March. 
OfFIONG, D. (1984), The Functions of the Ekpo Society of the Ibibio of Nigeria. African Studies Review 27(3): 82-4.

Олг, С. (2014), Pastor, Church Member Arrested for Killing Virgin for Ritual. The Sunnewsonline, 8 January 2014. sunnewsonline.com/new/cover/pastor-church-memberarrested-killing-virgin-ritual. Accessed 18 September 2014.

OKON, E. (2012), World-View and the Challenge of Witchcraft. Research on Humanities and Social Sciences 10(2): 34-41.

OKunOLA, R.A. \& M.D. OJo (2012), Oro Cult: The Traditional Way of Political Administration, Judiciary System and Religious Cleansing Among the Pre-Colonial Yoruba Native of Nigeria. The Journal of International Social Research 5(23): 20-26.

OluRode, L. (1990), A Political Economy of Nigeria's 1983 Elections. Lagos: John West Publications, pp. 54.

OnADEKo, T. (2008), Yoruba Traditional Adjudicatory Systems. African Study Monographs 29(1): 15-28.

SCHNOEBelen, J. (2009), Witchcraft Allegations, Refugee Protection and Human Rights: A Review of the Evidence, New Issues in Refugee Research, Research Paper No. 169, UNHCR, Policy Development and Evaluation Service Geneva 2 Switzerland.

STENBERG, S.H. (2010), Modernity Through the Eyes of Witchcraft: A Radical Critique of Categorisation. Global Discourse [Online] 1: I, available from: $<$ http://globaldiscourse.com/contents.

UNLocK, Nigeria (2012), Beyond Terror and Militants: Assessing Conflict Risk in Nigeria, The Fund for Peace Publication FFP Version 12. 


\title{
Muslims, Christians and religious Violence in Nigeria: Patterns and mapping (2006-2014)
}

\author{
Akinola Ejodame Olojo
}

\begin{abstract}
The notion that religious violence in Nigeria is always characterized by conflicts between religions (Muslims versus Christians) is too simplistic. This study shows that between June 2006 and May 2014 the frequency of violent death incidents involving Islamic groups against Islamic groups is 60, a figure higher than 57, which is the frequency of violent death incidents involving Islamic groups against Christian groups or churches within the same period. A second major point in this paper is that violence involving religious groups is not always caused by religious issues. This explains why the frequency of violent death incidents involving Islamic groups against Christian groups or churches due to non-religious issues is as high as 42 between June 2006 and May 2014. Thirdly, it remains inconclusive whether or not more Muslims than Christians (or vice versa) are killed because of violence in general in Nigeria. Finally, the Western media frames violence in Nigeria as being mainly interreligious, while lethal incidents involving Islamic groups against Islamic groups are largely under-reported.
\end{abstract}

\section{Introduction}

This paper is an attempt to sketch out and analyse the evolution and diverse patterns of violent deaths involving Muslims and Christians in Nigeria between 1 June 2006 and 31 May 2014. ${ }^{1}$ Although this nationwide mapping offers representations of the broad spectrum and character of Muslim-Christian religious violence over the eight-year period in focus, it also includes the dynamics of violent deaths of a non-religious nature involving Muslims and Christians. Our assessment also considers the violent interaction between Muslim and Christian groups in relation to other protagonists associated with religious and non-religious is-

1 This period is chosen because the Nigeria Watch database began recording data in June 2006, and this study seeks to analyse the available data over an eight-year period. 
sues. Without doubt, the religious institutions of Islam and Christianity in Nigeria are major rallying points for various social and political groups with disparate and sometimes obscure agendas. In fact, the almost ubiquitous use of religious pretexts in Nigeria has at several periods been appropriated by 'non-conforming' groups to instigate violence and inadvertently give the impression that religion is the paramount source of violence in the country.

However, this study finds that while the factor of religion cannot be entirely disregarded, particularly in light of the character of recurrent crises in (northern) Nigeria, religious issues do not represent the only cause of violent deaths involving Muslims and Christians in the country. Religion as a causal factor must be put in perspective and nuanced with other pertinent sources of violent deaths, such as issues related to land and territorial claims, ethnicity, and politics and elections, as well as community violence and crimes involving Muslims and Christians. In addition, this study finds that in cases where religion appears to be an underlying cause of violent deaths, such incidents can also be reflected in clashes between just one of the religious faiths and a non-religious protagonist, or in fact occur within the same religious faith.

The study thus explores the aforementioned dimensions and causes of Muslim-Christian violent deaths, and our analysis is corroborated by maps and graphs of data drawn from the statistical records of Nigeria Watch. Our focus raises several important questions for this study, and three main ones are considered: First, what factors explain why the dynamics of Muslim-Christian religious violence appear to gain more local and international traction in academic and media circles, in contrast to the attention accorded to the narratives of intra-religious violence, for instance? Second, if religious issues are not the only cause of violent deaths between Muslims and Christians in Nigeria, which other factor(s) also merit deeper investigation, based on the available data? Third, in connection with other key protagonists such as the security forces, to what extent are the Islamic and Christian faith blocs involved or implicated in incidences of violent deaths in Nigeria? We address these questions in the three main sections of this paper. Following this summary, a description of the general context of religion and violence in Nigeria will be provided and accompanied by brief reference to one of the major theoretical discourses - the 'clash of civilizations' - that continues to frame academic (and media) debates on inter-religious tensions in countries such as Nigeria. Bearing in mind the second question in this study, we then move on swiftly to the second part of this paper to characterize the distribution of data related to violent deaths between June 2006 and May 2014. This is done in an attempt to reveal in a statistical way the main causes of violent deaths and their correlation with both religious and non-religious issues involving Muslims and Christians. 
From this point, the third part of this study guides our focus in line with our third question. Based on the data presented, our statistical narrative here enables an understanding of the extent to which Islamic and Christian actors and groups are involved in the phenomenon of violent deaths. This is also examined in association with the role of other protagonist variables implicated in incidences of violent deaths where Muslims and Christians are involved. The concluding section will highlight our findings and underscore what is instructive for further research, based on the overall empirical content analysed in this study.

In this paper, reference to violent deaths does not exclusively denote the act of perpetration of violence on the part of Muslims or Christians. Rather, the context of our interpretation of violent deaths refers to the involvement of Muslims and Christians also as victims. It should also be noted that the period under examination starts on 1 June 2006 and ends on 31 May 2014. Therefore, apart from the full years in between (2007-2013), data analysed in relation to either 2006 or 2014 should be considered in light of the stipulated period when data collation and analysis started and ended.

\section{Religion and violence in Nigeria}

Violence in Nigeria has taken various forms over the decades, and the data in this study depicts its wide-ranging character expressed through the interactions between Muslims and Christians. Political issues, especially those associated with the struggle for elective offices and power allocation, remain a potent source of violence. This state of affairs is often catalyzed by a lethal infusion of interests rooted in deep socio-economic and ethnic concerns, some of which may be legitimate and others spuriously held by different actors and groups. In addition, the overall frequency of violent deaths in Nigeria owes much to a combination of other causes such as car accidents and crime. And certainly, not least, religious issues appear to also reinforce the collective tally of fatalities, particularly in terms of recurrence rates in regions such as northern Nigeria.

Scholarly interpretations of this religious angle hold significance because of the added perspective they bring to our assessment of Muslim and Christian involvement in the trends of violent deaths. However, in instances where violent deaths are not underscored by religious issues between Muslims and Christians, or in cases where violent deaths transpire between groups of the same religious faith, it raises questions regarding the limits of certain theoretical paradigms and how effectively their frameworks capture the violent interaction between adherents of religious faiths in Nigeria. One such paradigm pertains to the 'clash of civilizations', which suggests that civilization identity, of which religion is a core component, will be increasingly important in the post-Cold War period. Samuel 
Huntington, the main proponent of this acclaimed yet widely criticized civilizational thesis went further to assert that the fundamental source of conflict and great divisions will be cultural and that the fault lines between civilizations, being the broadest level of cultural identity, will be the battle lines of the future (Huntington 1996).

To a certain degree, some of the fundamental conflicts evident in the era Huntington prognosticated about have indeed found some expression along religious fault lines, and particularly in relation to Islam in countries such as Nigeria. The academic literature is also instructive in the way it guides our thoughts on the central role of religion. Ellis and Haar (2007) describe religion as an emerging political language whose pattern of interaction cannot be ignored in the study of African politics. For Matthew Kukah (1993), the process of political bargaining in Nigeria appears to increasingly embody the factor of religion. Toyin Falola (1998) pushes this further by underscoring the profundity of religious attachment expressed by both Muslims and Christians and its instrumentality in political life and leadership in Nigeria.

In the overall estimation of various scholars writing on religion and politics in Nigeria, there appears to be an almost seamless connection between several violent incidents from the 1960s through the decades up to the current period. And at different phases in this historical trajectory, the controversy between Muslims and Christians over the definition and interpretation of 'secularity', for instance, has offered opportunities for analysts to gauge what they see as diametrically opposed platforms of Muslims against Christians in Nigeria. A typical instance appeared in 1976 during the drafting of Nigeria's Constitution and then again in 1986 on the occasion of Nigeria's admittance into the Organisation of Islamic Conference (OIC), which sparked off intense debates between Muslims and Christians. The common thread of 'fundamentalism' that also runs through these decades has often given way to militant expressions on both sides of the religious divide in Nigeria. On the one hand, for instance, northern Nigerian Christians, arguing self-defence, have in the past justified the use of militancy to protect their lives and defend their faith through the use of physical violence. On the other hand, however, Islam appears to have gained a wider reputation for militancy than Christianity, as clearly more cases of religious violence involving Islamist groups are reported (Falola 1998).

The cumulative reality of these events appears to mirror the classical model of a religious clash involving Muslims and Christians in the country. Thus, when a superficial reading of the prevailing Boko Haram crisis is carried out, the penchant to anchor analysis exclusively on Huntington's discourse and assume the reflection of a clash between a 'Muslim North' and 'Christian South' is reinforced. Besides, Boko Haram itself purportedly calls for a Sharia state, and the 
several incidences of violence instigated against Christians or representations of Western civilization in Nigeria tend to receive considerable media interest and hype both locally and internationally. The overall impression of a civilizational clash involving Muslims and Christians is also strengthened in some way by the phenomenon of the 'youth bulge' in Africa and particularly in the case of Nigeria where the demographic structure is characterized by nearly three-quarters of the population being under the age of 30 (Leahy et al. 2007). The portrayal of such a population trend in a country where there is an exceedingly large and mismanaged youth population invokes the notion of how easily violent deaths can be a consequence of youth vulnerability in the hands of radicalized (religious) groups. By extension, it also becomes easy to understand how much analysis of the violence involving Muslims and Christians in Nigeria maintains intellectual currency within academic debates, policy circles, and the sensational projection of the global media.

Beyond this, however, the connections between the aforementioned variables are far more complex than what fits perfectly into a single theoretical paradigm about a clash between religions. The religious divide between Muslims and Christians should not be overstated, because the monolithic perception held by many observers of Islam and Christianity in Nigeria should be balanced with the sense of caution expressed by scholars such as Pérouse de Montclos. He draws attention to the need to recognize the divisions within Islam as well as disruptive factors within the Muslim ummah, which crises such as that related to Boko Haram underscore (Pérouse de Montclos 2014). This kind of perspective holds merit as a safeguard against speculative counter-arguments about an inter-religious clash and also as a guide for other aspects of our study, which will permit a fuller understanding of the idea of divisions or schisms within religions such as Islam in Nigeria. Particularly in the third part of this paper, an appreciation of this will emerge through our statistical presentation of violent trends between rival groups aligned to the same religion. However, before reflection on this, we will proceed to present and analyse the distribution of data related to the causes of violent deaths and its relationship to religious and non-religious issues involving Muslims and Christians.

\section{Frequency of violent deaths and their causes}

Between 1 June 2006 and 31 May 2014, the absolute number of violent deaths recorded by the Nigeria Watch database was over 61,000 (Figure 5.1). This staggering number is spread out over the period examined in this study. Although an observable feature of this data is the steady rise in the absolute yearly frequency of deaths from 2009 to 2013, a critical look at 2014 reveals a sharp increase in 
the measure of absolute frequency just within a period of five months. Furthermore, in less than a year's span, the aggregation of violent deaths for the first five months of 2014 exceeds the absolute frequency of violent deaths for each of the preceding years, with the exception of 2013. Subsequent events confirmed this alarming trend.

Figure 5.1 Absolute number of violent deaths per year (June 2006-May 2014)

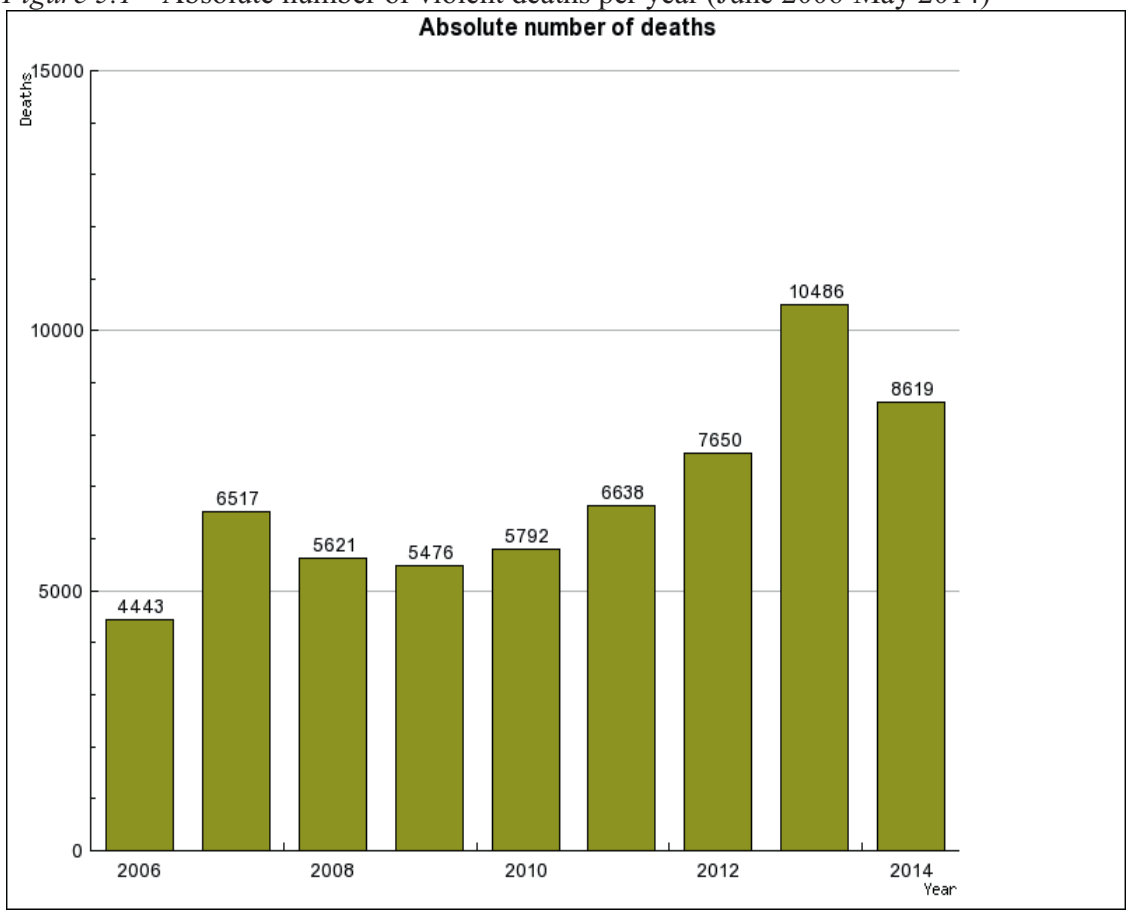

Yet Figure 5.1 does not provide a clear enough impression of which factors act as instigators of lethal violent. Figure 1.2 takes us a little closer by fine-tuning our focus. Between June 2006 and May 2014, religious causes thus accounted for over 11,300 violent deaths. Some other causal factors registered higher frequencies, and two major variables were crime and car accidents, with over 27,000 and 15,000 fatalities, respectively. The data shows that religious issues did not constitute the main cause of violent deaths, taken in absolute terms, over the past eight years. However, if we focus on the data on absolute fatalities caused by religion and distribute it over the eight-year period, it will permit us to gauge the proportion of violent deaths attributable to religious issues on a yearly basis (Figure 5.2). This is possible when we compare the yearly data on religious causes of 
violent deaths (Figure 5.2) with the yearly data on absolute number of violent deaths (Figure 5.1). In the process, even though we are still unable to view proportions of Muslim and Christian involvement in violent deaths, we are able to detect the relative influence of religious issues, especially during years such as 2013 and 2014. If we consider 2014, for instance, not only did violent deaths rise dramatically, but religious issues accounted for nearly half the number of violent deaths in the first five months. The reason for this high proportion is closely associated with the dynamics of violent deaths caused by the Boko Haram crisis in northern Nigeria. We will shed some light here because the spikes in violent deaths for 2013 and 2014 are also linked to the involvement of Muslims and Christians in violence, either as perpetrators or victims.

Figure 5.2 Violent deaths caused by religious issues, per year (June 2006-May 2014)

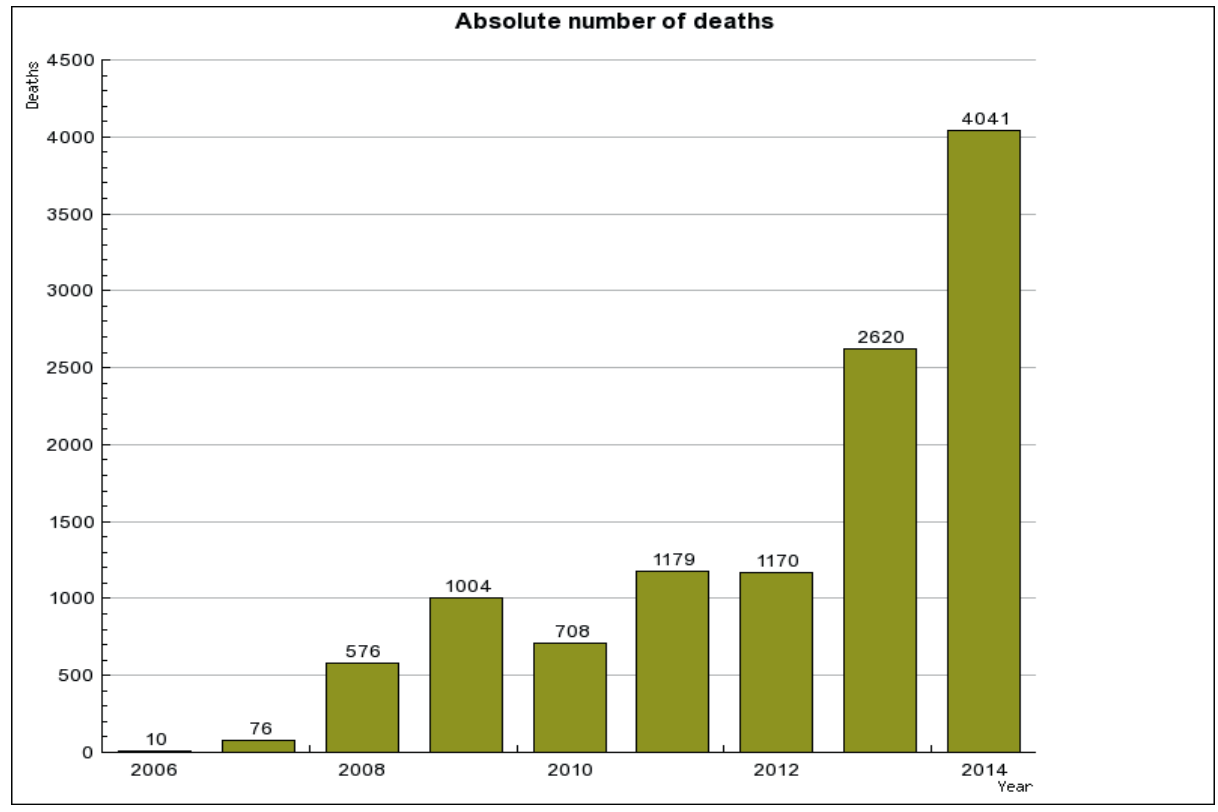


Map 5.1 Fatalities caused by religious issues in Nigeria (June 2006-May 2014)

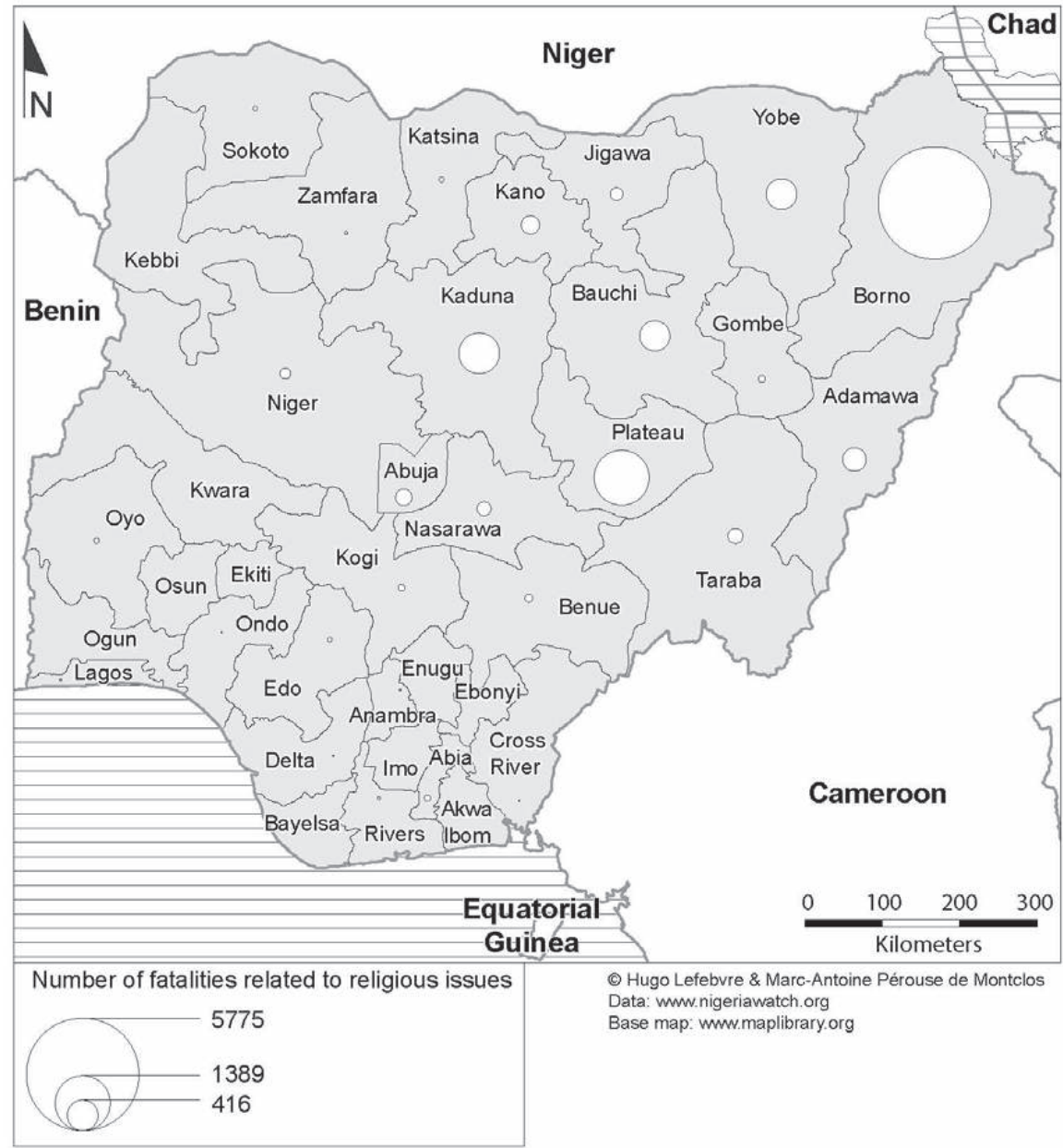

Violent deaths in 2013 and 2014

The year 2013 had the highest frequency of violent deaths in the country, with an absolute figure of 10,486, while 2014 followed with a similar trend. Although factors such as crime are a foremost cause of violent deaths across the entire eight-year period, issues located within the context of religion were the underlying reasons for the escalation of violent deaths in 2013 and 2014. The religious issues in question here are attributable, of course, to the Boko Haram crisis, which at the same time explains the spike in violent death rates in places such as Borno State in 2013 and 2014 (Figures 5.2 and Map 5.1). These were particularly violent years, as the group calling itself the Jama'atu Ahlis Sunnah Lidda'awati wal-Jihad (widely known as Boko Haram) was responsible for numerous attacks 
against the security forces and civilians, Muslim and Christian alike. It should be noted, however, that the death timeline as a result of Boko Haram attacks can be traced back to periods before 2013. In fact, in December 2003, members of the sect reportedly launched a series of deadly attacks on police stations in northern cities such as Kanama in Yobe State. However, such instances in the past pale in comparison with the sequence of violent onslaughts by the group in 2013 and 2014. While the generation of an entire list of these attacks is not the main focus of this section, some major incidents involving the fatalities of both Muslims and Christians stand out owing to the scale of the loss of lives involved. ${ }^{2}$

In September 2013, approximately 50 students of the School of Agriculture in Guijba were reportedly killed in Yobe State. This event was preceded by the massacre of approximately 49 people in August following an attack on a mosque and several villages, including Konduga and Malari, in Borno State. The degree to which lives were lost in single attacks in 2014 was unprecedented, based on the fatality records in the Nigeria Watch database. In February 2014, gunmen suspected to be Boko Haram members killed at least 47 people in Bama and Buratai in Borno State. Within the same state (and month), Boko Haram insurgents attacked Izghe village and killed 106 people. If there exist doubts regarding the identity of the perpetrators of some of these attacks, Boko Haram publicly claimed responsibility for the April 2014 bomb blast that claimed the lives of at least 70 people at a mass transport terminal in Nyanya, Abuja.

A final example is that involving the death of hundreds of individuals during a clash between security operatives and Boko Haram members who launched an attack on Giwa Military Barracks in Borno State in March 2014. There were various casualty accounts rendered by the Nigerian press community, with the Vanguard newspaper suggesting 207 deaths, ThisDay reporting 350, and Daily Trust stating that as many as 500 lives were lost (Nigeria Watch database 2014). It should be noted, however, that exact figures remain a subject of debate and so also is the problematic issue of identifying the precise religious identity of some of the victims of these attacks. As a matter of research, Chouin, Reinert and Apard (2014) set out this thinking eloquently, and they attest to the particular difficulty in ascertaining the religious identities of several victims of Boko Haram attacks with complete accuracy. Notwithstanding, the findings of these scholars suggest that the majority of the victims of Boko Haram attacks - around two-thirds - are in fact Muslims. This of course challenges the commonplace temptation to understand the crisis as a war between religions. For our study's focus, what is also not in doubt is the diverse range of actors who comprise the casualty figures: the fatality profiles consist of victims who are Boko Haram in-

\footnotetext{
2 These events were retrieved from the Nigeria Watch database.
} 
surgents, members of the Nigerian government's Joint Task Force (JTF), and Christian and Muslim civilians.

\section{Frequencies of Muslim and Christian violent deaths}

We have been able to establish to some degree the impact of religious issues on the escalation in the number of violent fatalities in certain years, such as 2013 and 2014. The added bearing of the Boko Haram crisis on the connection between religious issues and fatalities has also been highlighted. Without disregarding the relevance of this link, we must at the same time keep in mind one of the questions of this study, which underscores the interrogation of non-religious causal factors of violent deaths involving Muslims and Christians as well as the role of other non-religious protagonists that have at certain periods been implicated in the phenomenon of violent deaths involving either Christian or Islamic groups. Once again, we must emphasize that the frequency of violent deaths involving Muslims and Christians does not always express a connection with religious issues only. One way to test this is to compare the data in the yearly frequencies of violent deaths linked to religious issues with the yearly frequencies of violent deaths linked to the involvement of Christians. In other words, compare the data presented in Figure 5.2 with that of Figure 5.3. By doing so, we can identify a year such as 2008, when the frequency of violent deaths involving Christians (605 fatalities) was higher than the frequency of violent deaths linked to religious issues (576 fatalities). This disparity can be understood, of course, in light of the fact that in November 2008, there were comparably higher numbers of Christian fatalities (protagonists and victims) following ethno-political clashes over local government election results in Plateau State.

We can also apply this same principle of comparison to the Islamic context. To test this, we can compare the data in the yearly frequencies of violent deaths linked to religious issues with the yearly frequencies of violent deaths linked to the involvement of Muslims. While still drawing upon our comparative data in Figures 5.2 and 5.3, we can identify years such as 2012 when the frequency of violent deaths involving Muslims (2,033 fatalities) was higher than the frequency of violent deaths linked to religious issues (1,170 fatalities). Similar to the way we explained the case with Christian fatalities, the observed disparity here can also be understood against the background of violent clashes and deaths that involved Muslims or Muslim groups in relation to issues that are not necessarily religious in nature. 
Figure 5.3 Violent deaths involving Islamic and Christian groups, per year (June 2006-May 2014)

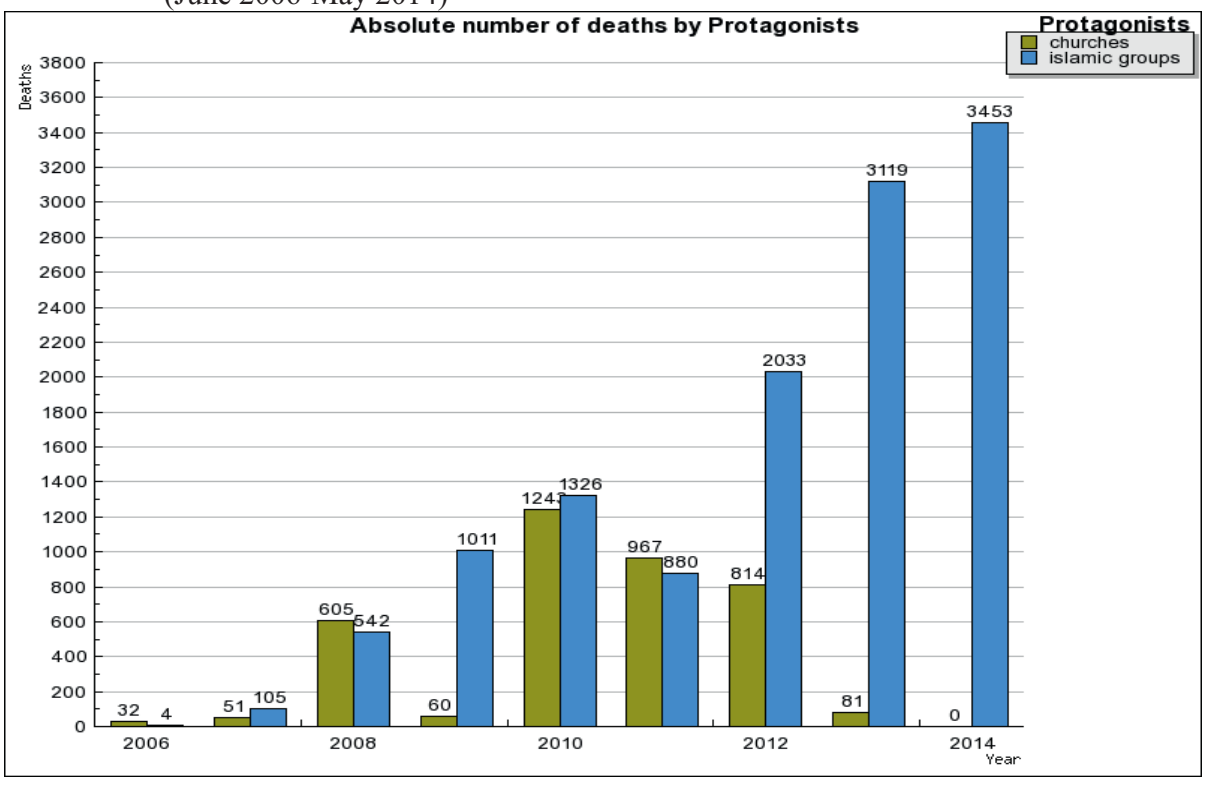

At the heart of these comparisons is the fact that there are certain fatalities which are attributable to entirely non-religious issues involving Muslims and Christians. This explains to an extent why there are certain years reflecting lower frequency bars for religious causes of violent deaths in comparison with higher frequency bars for either Islamic- or Christian-related violent deaths in the country. In other words, the existence of 'excess' fatalities explains why the frequency bars for Islamic and Christian groups are at certain periods higher than the frequency bars for religious causes.

There were certainly other years that reflected higher frequencies of violent deaths involving Muslims in comparison with the frequencies of violent deaths linked to religious issues. These periods include 2007, 2009, 2010, and 2013. However, the fatalities that contributed to making these years particularly higher in frequency are, of course, not only linked to non-religious issues such as politics or land/territorial crisis; they are also linked to the role of what we referred to earlier as non-religious protagonists. In this regard, while the causes of violent deaths may indeed be religious, one of the actors involved in a violent encounter may be a Christian or Islamic group and the other a state security entity such as the police or the JTF.

As it appears in our data and especially when we make reference to Figure 5.3, there are comparably more yearly periods that reflect higher frequency levels of 
violent deaths involving Muslims or Islamic groups. Typical cases include 2012 and 2013, which far outweigh the frequency of violent deaths involving Christians or Christian groups. Although, as we have noted all along, this high frequency on the Muslim side entails a combination of both perpetrators and victims of violence, it is the kind of disparity which has led scholars such as Falola (1998) to suggest that Islam has gained a wider reputation for militancy than Christianity. It is also the kind of disparity which in a metaphoric sense is a reminder of Huntington's (1996: 254) analysis of the phenomenon he describes as 'Islam's bloody borders'.

\section{Beyond frequencies: Dimensions of violent death incidents}

Returning to our data, we will try to expound further on these 'excess' fatalities involving Christian and Islamic groups, which appear to fall outside the scope of religious issues. We will expand our framework to also examine some of these non-religious protagonists implicated in the phenomenon of violent deaths involving Christian and, particularly, Islamic groups. In doing so, we will look beyond the frequency of violent deaths to examine more critically the nature of the issues themselves. The frequencies of violent deaths tell us one thing, but the frequencies of the violent incidents that produce these violent deaths reveal even more. This opens up in several interesting ways another dimension of our study. First, it facilitates our knowledge of the frequency of these incidents involving Christian and Islamic groups in addition to just the frequency of the violent deaths reflected in the graphs so far. Second, we will have more knowledge of the extent to which non-religious issues involving Christian and Islamic groups occur and recur each year. And third, we will further be able to gain a clearer sense of the proportions which these non-religious and religious issues hold in relation to each other, as well as the correlational dynamics between the different protagonists between June 2006 and May 2014.

Table 5.1 is therefore an attempt to capture the aforementioned explanation through the display of various frequencies of violent death incidents of which religious and non-religious issues are casual factors with the involvement of Muslim and Christian groups, as well as their linkages with other key protagonists. The search method used in generating the data in this table employed the use of the key words 'Islamic groups' and 'Churches' in the Nigeria Watch database. When these specific key words are utilized in a search like this on the database, the data generated includes violent incidents involving Islamic groups and Christian groups, as well those incidents that share a nexus with intra-group violence within either of the religious faiths. Additional data generated through this search method includes incidents of both a religious and non-religious character 
which have a lethal connection between either of the religious faiths and other non-religious protagonists.

For each year, all the data generated is classified under six main rubrics: Islamic group versus Christian group (religious issues); Islamic group versus Christian group (non-religious issues); Islamic group versus Islamic group (religious issues); Islamic group versus Security forces (JTF, police); Islamic group versus Vigilante group, Civilian JTF; and Other Violent Death Incidents involving Muslims and Christians (Community violence). With reference to specific incidents, where necessary we will analyse the data under each rubric one at a time.

Table 5.1 Frequencies of violent death incidents involving Muslims and Christians (religious and non-religious issues) (June 2006-May 2014)

\begin{tabular}{lcccccc}
\hline Year & $\begin{array}{c}\text { Islamic group } \\
\text { vs. Christian } \\
\text { group (reli- } \\
\text { gious issues) }\end{array}$ & $\begin{array}{c}\text { Islamic group } \\
\text { vs. Christian } \\
\text { group (non- } \\
\text { religious } \\
\text { issues) }\end{array}$ & $\begin{array}{c}\text { Islamic group } \\
\text { vs. Islamic } \\
\text { group (reli- } \\
\text { gious issue) }\end{array}$ & $\begin{array}{c}\text { Islamic } \\
\text { group vs. } \\
\text { Security } \\
\text { forces (JTF, } \\
\text { police) }\end{array}$ & $\begin{array}{c}\text { Islamic } \\
\text { group vs. } \\
\text { Vigilante } \\
\text { group, Civil- } \\
\text { ian JTF }\end{array}$ & $\begin{array}{c}\text { Other violent death } \\
\text { incidents involving } \\
\text { Muslims and Chris- } \\
\text { tians (community } \\
\text { violence) }\end{array}$ \\
\hline 2006 & 2 & 0 & 1 & 0 & 0 & 18 \\
2007 & 3 & 0 & 5 & 1 & 0 & 19 \\
2008 & 2 & 1 & 0 & 0 & 0 & 25 \\
2009 & 0 & 2 & 4 & 10 & 0 & 18 \\
2010 & 8 & 4 & 9 & 11 & 0 & 35 \\
2011 & 5 & 33 & 20 & 66 & 0 & 52 \\
2012 & 27 & 1 & 15 & 161 & 0 & 59 \\
2013 & 6 & 1 & 4 & 138 & 5 & 38 \\
2014 & 4 & 0 & 2 & 31 & 2 & 68 \\
TOTAL & 57 & 42 & 60 & 418 & 7 & 332 \\
\hline
\end{tabular}

\section{Islamic group versus Christian group (religious issues)}

Under this rubric, we take into account the recurrence rate of violent incidents with manifestations inspired by religious issues involving Christian and Islamic groups. A total of 57 incidents are identified, and 2012 represents the year with the highest rate of this type of incident between June 2006 and May 2014. In comparison with some other rubrics that possess higher frequencies of incidents reflected in Table 5.1, this total figure of 57 is once again a reminder of how religious issues do not represent the only cause or pattern of violent deaths involving Muslims and Christians in Nigeria. These religious incidents are nonetheless significant and are mainly comprised of three forms of violent encounters: first, attacks instigated by the Islamist group Boko Haram against Christian groups, with churches being a prime target; second, attacks through series of assassinations targeted at Christian clerics; and third - although to a lesser extent than the first and second forms - reprisal attacks by Christians against Muslims. 
The geographical locations of the majority of these incidents include Niger, Kaduna, Yobe, and Borno states, all of which are in the northern region of the country. Regarding the first form of violent encounter, instances include the bomb attacks on churches, notably Saint Theresa's Catholic Church in Madalla, Niger State on 25 December 2011. Other events include the attack on Saint Rita's Catholic Church, Kaduna State in October 2012, as well as numerous attacks on other church denominations in Borno State. Among several cases of assassinations, three clerical leaders affected were Reverend David Usman of the Church of Christ in Nigeria (COCIN), Reverend Ilaisha Kabura of the same COCIN, and Reverend Bulus Marwa of Victory Baptist Church. Table 5.2 provides further insight into the trend of Islamist-motivated (mostly Boko Haram) attacks on Christian clerics between June 2006 and May 2014. Finally, in regard to reprisal attacks by Christians, a typical case transpired in June 2012 in Kaduna State when scores of Muslims were killed by Christians following suicide bomb attacks on churches a few days earlier in the state.

Table 5.2 Violent deaths of Christian clerics due to Islamist (mainly Boko Haram)related attacks (June 2006-May 2014)

\begin{tabular}{|c|c|c|c|}
\hline $\begin{array}{l}\text { Name of Christian } \\
\text { cleric/leader }\end{array}$ & Church affiliation & $\begin{array}{l}\text { Location of } \\
\text { death/state }\end{array}$ & $\begin{array}{l}\text { Month of } \\
\text { death/year }\end{array}$ \\
\hline Reverend George Orji & $\begin{array}{l}\text { Good News of Christ Church Inter- } \\
\text { national }\end{array}$ & $\begin{array}{l}\text { Maiduguri, Borno } \\
\text { State }\end{array}$ & July 2009 \\
\hline $\begin{array}{l}\text { Reverend Sylvester } \\
\text { Akpan }\end{array}$ & National Evangelical Mission & $\begin{array}{l}\text { Maiduguri, Borno } \\
\text { State }\end{array}$ & July 2009 \\
\hline $\begin{array}{l}\text { Reverend Sabo Yaku- } \\
\text { bu }\end{array}$ & Church of Christ in Nigeria & $\begin{array}{l}\text { Maiduguri, Borno } \\
\text { State }\end{array}$ & July 2009 \\
\hline $\begin{array}{l}\text { Reverend Bulus } \\
\text { Marwa }\end{array}$ & Victory Baptist Church & $\begin{array}{l}\text { Maiduguri, Borno } \\
\text { State }\end{array}$ & Dec 2010 \\
\hline $\begin{array}{l}\text { Pastor Michael Madu- } \\
\text { gu }\end{array}$ & Deeper Life Bible Church & $\begin{array}{l}\text { Maiduguri, Borno } \\
\text { State }\end{array}$ & Jan 2011 \\
\hline $\begin{array}{l}\text { Reverend David Us- } \\
\text { man }\end{array}$ & Church of Christ in Nigeria & $\begin{array}{l}\text { Maiduguri, Borno } \\
\text { State }\end{array}$ & June 2011 \\
\hline $\begin{array}{l}\text { Reverend Ilaisha Ka- } \\
\text { bura }\end{array}$ & Church of Christ in Nigeria & $\begin{array}{l}\text { Maiduguri, Borno } \\
\text { State }\end{array}$ & Nov 2012 \\
\hline $\begin{array}{l}\text { Reverend Yohanna } \\
\text { Agom }\end{array}$ & Saint Joseph's Anglican Church & Nangere, Yobe State & Sept 2013 \\
\hline
\end{tabular}

\section{Islamic group versus Christian group (non-religious issues)}

With 42 incidents between June 2006 and May 2014, the details under this rubric attest to violent death dynamics typified by non-religious causes involving Muslims and Christians in Nigeria. Although the non-religious causes may appear insubstantial in terms of recurrence rates, their importance can still not be ig- 
nored. Based on the data, they represent violent deaths connected with issues such as election to political office. The years 2008, 2010, and 2011 stand out in relation to these non-religious causes and, to various extents, states such as Plateau, Kaduna, Kano, and Bauchi bear witness to this. In Plateau State, for instance, November 2008 was a critical period for local government elections in Jos North, where a tense political struggle for power pitched the People's Democratic Party (PDP) against the All Nigeria Peoples Party (ANPP).

In Jos North, voters were polarized because the PDP was made up of mostly Christian supporters and the ANPP largely comprised the Jasawa, who are mainly Muslims of Hausa/Fulani ethnic make-up. Only to this extent did this combination create an entry point for religion in the local government election crisis, because the crisis which led to a reported 350 to 500 deaths (some estimates are higher) in just two days was essentially political in nature. In fact, in the account rendered by Philip Ostien (2009), he explained that although religious difference adds fuel to the fire when things go wrong, it remains a secondary factor. Ostien thus emphasized that the underlying problem stems from the alleged rights of indigenes (meaning roughly 'earliest extant occupiers') to control particular locations, as opposed to the rights of 'settlers' or 'strangers' (or more generally 'nonindigenes'), defined as everybody who came later.

The violent fallout from election results recurred in April 2011. However, this time, clashes between Muslims and Christians were due to presidential elections in which the main opposition candidates, Muhammadu Buhari, a northern Muslim from the Congress for Progressive Change (CPC), lost to the incumbent President Goodluck Jonathan, a Christian from the Niger Delta in the South, who was the candidate for the ruling PDP. As with the previous crisis, the violence that ensued divided opposing parties and their supporters along ethnic and religious lines. However, the underlying cause was largely political and more widespread because violent deaths involved Muslims and Christians in places such as Zangon-Kataf and Kachia in Kaduna State, Alkaleri and Itas/Gadau in Bauchi State, and Kano Municipal in Kano State.

\section{Islamic group versus Islamic group (religious issues)}

Our mapping study will not be complete without delving into the dimension of the violent interplay between and among Islamic groups. With a total of 60 incidents of intra-Islamic violent deaths, it is vital to consider the character of these events. They are divided into two broad categories: violent deaths due to clashes between Sufi brotherhoods such as the Tijaniyya and groups such as the Yan Izala; and, in the second case, violent deaths due to clashes involving either of these Islamic brotherhoods (and sects) and Boko Haram. The incidents involved in both categories are underpinned by religious issues and usually stem from dif- 
ferences in the interpretation of Islamic doctrines. However, the violent outcomes of these divergent interpretations of Islamic tenets are more pronounced in regard to the second category, that involving clashes between Islamic groups and Boko Haram. This is evident not only in the frequency of incidents but also in the number of fatalities as a result of incidents. These incidents also entail in some cases attacks on mosques by the rival Islamist sect Boko Haram. More significant in the second category is the nature of the fatalities involved, which include an increasing number of Islamic clerics. Table 5.3 is a list of some of these clerics reportedly attacked and killed by Boko Haram between June 2006 and May 2014.

There are a few of these assassination cases, however, whose source of perpetration is still shrouded in controversy. An example is that related to the death of Sheikh Ja'afar Mahmud Adam. In such cases a direct link to Boko Haram remains inconclusive. The locations of most of these intra-Islamic violent death incidents include states such as Kaduna, Yobe, and Borno. Some of the intergroup clashes observed in the data tend to often involve the Shi'ite Islamic movement. There are three notable occurrences in regard to this: The first was in January 2009, when Shi'ite adherents in Zaria, Kaduna State clashed with a rival Islamic group following accusations by this group against the Shi'ites of attacking the convoy of the Emir of Zaria. In January 2011, violent encounters ensued again between the Shi'ites and members of the Tijaniyya Sufi brotherhood in Kaduna State. A third instance was in October 2013, when Shi'ite members clashed with Sunni youths in Sokoto State. These incidents, in which the Yan Shi'a movement led by Sheikh Ibrahim El Zakzaky was implicated, do not in any way downplay the violent complicity of groups such as the Yan Izala, which indeed clashed with members of the Tijaniyya Sufi brotherhood in October 2013 in Zamfara State.

It was noted earlier that the second category of violent deaths caused by intraIslamic clashes refers specifically to attacks instigated by Boko Haram against the entire cross-section of Islamic groups in Nigeria. Similar to the desire of several of these Islamic movements in the country, Boko Haram advocates a nationwide application of Sharia. However, the line of disparity between these Islamic groups and Boko Haram is drawn based on the aggressive modus operandi which Boko Haram adopts. As a result, it is indeed the case that the majority of these Islamic groups are in fundamental disagreement with Boko Haram, and it is this point of divergence that contributes to the provocation of 
Table 5.3 Violent deaths of Islamic clerics due to Islamist (mainly Boko Haram)related attacks (June 2006-May 2014)

\begin{tabular}{|c|c|c|c|}
\hline $\begin{array}{l}\text { Name of Islamic } \\
\text { cleric/leader }\end{array}$ & Islamic affiliation & $\begin{array}{l}\text { Location of } \\
\text { death/state }\end{array}$ & $\begin{array}{l}\text { Period of } \\
\text { death/year }\end{array}$ \\
\hline $\begin{array}{l}\text { Sheikh Ja'afar Mahmud } \\
\text { Adam }\end{array}$ & $\begin{array}{l}\text { Jama't Izalat al Bid'a Wa } \\
\text { Iqamat as Sunna or Yan Izala }\end{array}$ & Kano State & Apr 2007 \\
\hline Sheikh Bashir Mustafa & Not indicated & $\begin{array}{l}\text { Maiduguri, Bor- } \\
\text { no State }\end{array}$ & Oct 2010 \\
\hline $\begin{array}{l}\text { Ustaz Ibrahim Ahmed } \\
\text { Abdullahi Gomari }\end{array}$ & Not indicated & $\begin{array}{l}\text { Maiduguri, Bor- } \\
\text { no State }\end{array}$ & Mar 2011 \\
\hline Sheikh Goni Tijjani & Not indicated & $\begin{array}{l}\text { Maiduguri, Bor- } \\
\text { no State }\end{array}$ & May 2011 \\
\hline Mallam Alhaji Abur & Not indicated & $\begin{array}{l}\text { Maiduguri, Bor- } \\
\text { no State }\end{array}$ & May 2011 \\
\hline Sheikh Ibrahim Birkuti & Wahabbi & Biu, Borno State & June 2011 \\
\hline Liman Bana & Not indicated & $\begin{array}{l}\text { Maiduguri, Bor- } \\
\text { no State }\end{array}$ & Aug 2011 \\
\hline Mallam Dala & Not indicated & $\begin{array}{l}\text { Maiduguri, Bor- } \\
\text { no State }\end{array}$ & Sept 2011 \\
\hline Sheikh Ali Jana'a & Not indicated & $\begin{array}{l}\text { Maiduguri, Bor- } \\
\text { no State }\end{array}$ & Oct 2011 \\
\hline Mallam Mai Tatabara & Not indicated & $\begin{array}{l}\text { Damaturu, Yobe } \\
\text { State }\end{array}$ & Feb 2012 \\
\hline $\begin{array}{l}\text { Modu Goroma (Arabic } \\
\text { teacher) }\end{array}$ & Not indicated & $\begin{array}{l}\text { Damaturu, Yobe } \\
\text { State }\end{array}$ & Feb 2012 \\
\hline $\begin{array}{l}\text { Sheikh Saina Alhaji } \\
\text { Ajiya }\end{array}$ & Not indicated & $\begin{array}{l}\text { Konduga, Borno } \\
\text { State }\end{array}$ & Feb 2012 \\
\hline $\begin{array}{l}\text { Mohammed Alhaji Bu- } \\
\text { kar }\end{array}$ & Not indicated & $\begin{array}{l}\text { Maiduguri, Bor- } \\
\text { no State }\end{array}$ & Mar 2012 \\
\hline Goni Mustapha & Not indicated & $\begin{array}{l}\text { Maiduguri, Bor- } \\
\text { no State }\end{array}$ & Apr 2012 \\
\hline Mohammed Alli & Shiite & Kano State & May 2012 \\
\hline Usman Muhammed & Not indicated & $\begin{array}{l}\text { Potiskum, Yobe } \\
\text { State }\end{array}$ & May 2012 \\
\hline Sheikh Ibrahim Majimi & Not indicated & $\begin{array}{l}\text { Maiduguri, Bor- } \\
\text { no State }\end{array}$ & July 2012 \\
\hline $\begin{array}{l}\text { Alarama Dan Gobobira- } \\
\text { wa }\end{array}$ & Not indicated & $\begin{array}{l}\text { Potiskum, Yobe } \\
\text { State }\end{array}$ & Dec 2012 \\
\hline Mallam Sheriff & Not indicated & $\begin{array}{l}\text { Ngamdu, Yobe } \\
\text { State }\end{array}$ & May 2013 \\
\hline $\begin{array}{l}\text { Alhaji Liman Bukar } \\
\text { (Chief Imam) }\end{array}$ & Not indicated & $\begin{array}{l}\text { Fune, Yobe } \\
\text { State }\end{array}$ & Aug 2013 \\
\hline $\begin{array}{l}\text { Sheikh Muhammad Au- } \\
\text { wal Adam Albani }\end{array}$ & Salafiyyah & $\begin{array}{l}\text { Zaria, Kaduna } \\
\text { State }\end{array}$ & Feb 2014 \\
\hline
\end{tabular}


violence. Consequently, while 2011 reflected the highest frequency of Boko Haram attacks against several members of these Islamic groups and their mosques, 2012 was replete with a record number of assassinations targeted at Islamic clerics perceived as 'opponents'. Table 5.3, as already noted, lists some of these casualties.

\section{Islamic group versus the security forces}

The security forces constitute what this study has so far described as nonreligious protagonists. Although not the prime concern of this study, their role assumes some measure of significance owing to their violent interaction with one of the major variables (Islamic actors) examined in this paper. Thus, on the one hand we have the Islamist group Boko Haram, and on the other we have the security forces, comprised of members of the JTF, the Nigeria Police Force (NPF), and the State Security Service (SSS), among others. In addition, this rubric represents the highest number of violent death incidents (418) with which one of our major variables (Islamic actors) is connected. However, the lead-up to this high frequency of incidents appeared inconsequential until 2009, when figures (fatalities and incidents) began to accumulate.

It should be noted that among the several deaths that occurred in 2009, that of the former leader of Boko Haram, Mohammed Yusuf, marked a turning point in the level of violent encounters involving the Islamist group and the security forces. Consequently, more clashes ensued in 2010 and particularly in (August) 2011, which was also the year when the UN building was attacked. Events reached a violent crescendo in 2012, when as many as 161 incidents transpired, in places such as Damaturu and Potiskum in Yobe State, Zaria in Kaduna State, Tarauni in Kano State, and Dikwa and Maiduguri in Borno State. As at May 2014, there have been 31 violent death incidents involving members of Boko Haram and the security forces since the start of the year. Although this may not reflect a high frequency in comparison with the two preceding years, the incidents in the first five months of 2014 led to well over 3,000 deaths (Figure 5.3).

\section{Islamic group versus Vigilante group and Civilian Joint Task Force}

By mid-2013, when the Nigerian government imposed a state of emergency in north-eastern states such as Borno, the formation of what is now called the Civilian Joint Task Force (CJTF) became very visible amidst the violence instigated by the Islamist group Boko Haram. Since 2013, the CJTF, comprised mainly of youths whose families and communities have been ravaged by the state of unrest in the North-East, has engaged Boko Haram in a number of violent encounters. By way of counter-reaction, Boko Haram insurgents have extended their scope of attacks beyond battles waged against the state, religious clerics, and the govern- 
ment's JTF to engage members of the CJTF in several clashes. Although the CJTF does not constitute one of the leading variables of this study, their contribution to the overall frequency of violent deaths resulting from clashes with an Islamist group creates an entry point for them into the framework of our mapping study.

Our data reflects a total of seven lethal incidents involving the CJTF, five of which occurred in 2013 and two as at May 2014. In spite of the presence of the CJTF in a number of states within the troubled North-East, these incidents all transpired in Borno State. The incidents have largely manifested in three forms: The first entails situations whereby members clash with Boko Haram insurgents resulting in casualties on both sides as well as affecting the civilian population, as occurred in July 2013 in Kaga, Borno State. The second is when members are attacked/ambushed by Boko Haram insurgents, as reported in January 2014 when four CJTF members were killed in Mafa, Borno State. The third is when efforts by CJTF members and the government's JTF are jointly coordinated against Boko Haram insurgents. A case in point was in May 2014, when a Boko Haram attack was repelled and a reported 15 insurgents were killed in Konduga, Borno State.

\section{Other fatal incidents involving Muslims and Christians (community violence)}

The final aspect of our discussion on the patterns of Muslim-Christian violence deals with what we refer to as 'other violent death incidents involving Muslims and Christians'. The process of data generation for this rubric raises a slight methodological challenge, however, because it lends itself to the potential risk of including data from almost the entire spectrum of violent death incidents in the Nigeria Watch database. This is the case because nearly every individual (perpetrators and victims) connected with violent death incidents in the database most likely bears the identity of one of the two major religions in Nigeria-Islam and Christianity. Therefore, an effective definition of 'other violent death incidents involving Muslims and Christians' is accompanied by some level of difficulty and risk for meaningful analysis.

Hence, in order to mitigate the chances of collating an unwieldy set of data under this rubric, this study still maintained the approach of searching through the database using the key words 'Islamic groups' and 'Churches'. Thereafter, the violent death incidents which remained after data selection and classification under the five rubrics discussed earlier became defined as 'other violent death incidents involving Muslims and Christians'. However, to further qualify and give meaning to the leftover data that fell under this last rubric, each incident was analysed based on the complicity of Muslims and Christians in issues described as community violence. In other words, these 'other violent death incidents' are 
not consequential to direct conflict between Muslims and Christians or between groups within either of the religions. A total of 332 incidents were identified (Table 5.1), and a few cases are briefly cited here to illustrate what exactly we label as community violence.

In August 2006, the followers of a church known as Christian Praying Assembly, whose overseer was popularly known as Reverend King, clashed with a group of youths (Area Boys) in the Ebute-Metta area of Lagos State. Although this was a single incident, community violence can take other forms, however, and also involve other religious actors as well as more casualties. In February 2008 , for instance, 60 individuals were reported to have been tortured to death in illegal detention camps described as 'spiritual rehabilitation centres', which were run by 'Islamic clerics' in Ibadan, Oyo State. A third form of community violence involved a town called Gobi in Adamawa State. It was the scene of two bank robbery attacks leading to the death of seven individuals and carried out by the Islamist group Boko Haram in August 2011. Indeed, while this type of bank raid may be linked to other sinister groups in the state, Boko Haram has attempted to justify such robberies in light of their accusation against Western banks of being owned by 'big men' who siphon public funds and charge usury (Pérouse de Montclos 2014). The group has also claimed responsibility for attacks on public spaces such as the Baga fish market, where dozens of innocent people were killed in February 2012 in Borno State. And in spite of a similarity with its style of attacks against Islamic clerics, it often seems that religious motives do not factor into Boko Haram's targeting of communities and district heads in several parts of Borno State. The sheer increase in the number of violent death incidents in 2013 and 2014 reveals more and more non-religious community targets aimed at by the group, some of the incidents having included the killing of district heads in Dala Alamderi in Maiduguri and Lawanti in Damboa, and the invasion of villages in Gwoza, Konduga, and Bama in Borno State.

\section{Conclusion}

Understanding the true character of Muslim-Christian violent deaths between June 2006 and May 2014 requires knowledge of not only the religious dimension of this linkage; intellectual inquiries must appreciate also the cases of violent deaths inspired by issues connected with ethnicity, crime, land, and politics. We have established in this study that the essence of the violent interaction between Muslims and Christians is not devoid of the non-religious factors highlighted. The statistics presented in this paper have also illustrated that even in cases where religious issues underlie causes of violent deaths, the associated incidents can also reflect the involvement of non-religious actors. Furthermore, our map- 
ping demonstrates that religious causes of violent deaths can in fact manifest between groups belonging to the same religious faith. Within the context of geography, this paper finds that beyond any other region of Nigeria, the northern part embodies a preponderance of the violent interaction between Muslims and Christians. Finally, beyond local dynamics, global media perspectives consistently frame violence in Nigeria as largely religious and between Muslims and Christians, rather than adopting a more nuanced approach that enables a balanced interpretation of events.

\section{References}

Chouin, G., M. ReInerT \& E. ApARD (2014), Body Count and Religion in the Boko Haram Crisis: Evidence from the Nigeria Watch Database. In: M.-A. Pérouse de Montclos, ed., Boko Haram: Islamism, Politics, Security and the State in Nigeria. Leiden: African Studies Centre, pp. 213-236.

Ellis, S. \& G. TeR HAAR (2007), Religion and Politics: Taking African Epistemologies Seriously. Journal of Modern African Studies 45(3): 385-401.

Falola, T. (1998), Violence in Nigeria: The Crisis of Religious Politics and Secular Ideologies. New York: University of Rochester Press.

Huntington, S. (1996), The Clash of Civilizations and the Remaking of World Order. New York: Simon and Schuster.

KukaH, M.H. (1993), Religion, Politics and Power in Northern Nigeria. Ibadan: Spectrum Books Limited.

Leahy, E., R. Engelman, C. GibB Vogel, S. Haddock \& T. Preston (2007), The Shape of Things To Come: Why Age Structure Matters to a Safer, More Equitable World. Population Action International.

Ostien, P. (2009), Jonah Jang and the Jasawa: Ethno-Religious Conflict in Jos, Nigeria. Muslim-Christian Relations in Africa, 18-21. http://ssrn.com/abstract=1456372. Accessed 18 August 2015.

PÉROUSE DE MONTClos, M.-A. (2014), Boko Haram and Politics: Insurgency to Terrorism. In: M.-A. Pérouse de Montclos, ed., Boko Haram: Islamism, Politics, Security and the State in Nigeria, Leiden: African Studies Centre, pp. 135-157. 


\title{
Killings by the security forces in Nigeria: Mapping and trend analysis (2006-2014)
}

\author{
Super Odomovo Afeno
}

\begin{abstract}
Over the years, the Nigerian army has been regularly deployed to assist the police in law enforcement and internal security operations. This practice results largely from the belief that the presence of the security forces is sufficient to guarantee internal security. Data from the Nigeria Watch database, however, indicates that the intervention of the security forces in violent incidents often exacerbates the situation. This study shows that between June 2006 and May 2014 the security forces caused fatalities in 59\% of the lethal incidents in which they intervened. Secondly, the more the security forces intervene, the more people are killed. This explains why from an annual average of $59 \%$ between June 2006 and May 2007, killings by the security forces peaked at $80 \%$ between June 2013 and May 2014. Thirdly, 58\% of police interventions cause fatalities compared with $60 \%$ in the case of the army, an indication that killings by the police are more prevalent, while the army cause more fatalities per incident. Lastly, killings by the security forces are more prevalent in the southern part of the country but cause more fatalities in the northern part.
\end{abstract}

\section{Introduction}

This paper analyses the evolution and patterns of killings by the security forces in Nigeria between 1 June 2006 and 31 May 2014. This nationwide mapping focuses on the dynamics of security forces killings, including the political dimensions of violent incidents involving the security forces. The study also considers the intervention of the security forces in violent incidents involving religious groups and criminal gangs. The interactions between the security forces and these groups are often characterized by violence and, in most cases, result in deaths. In fact, 
the intervention of the security forces in violent incidents often exacerbates the situation and causes more deaths than the earlier stages of the incidents. ${ }^{1}$

Deaths resulting from the intervention of the security forces are sometimes overstated in both media and individual reports, while the security forces themselves rarely admit to causing deaths in their operations. This study discovered that while media reports and victims' accounts cannot be entirely disregarded, there are many inconsistencies in the reported number of fatalities caused by the security forces. Although it is very likely that media and victims' accounts overstate the number of fatalities, the security forces are notorious for either overstating or under-reporting the number of fatalities, depending on the context. The security forces usually give lower fatality figures when reporting to the international media, and they present higher fatality figures at home to create the impression that they are living up to their mandates. Hence, reports by the security forces rarely provide accurate figures and often reveal many discrepancies when compared with media reports and individual accounts. This makes it difficult to reliably analyse the trends and patterns of security forces killings nationwide.

In view of the difficulty in arriving at reliable fatality figures, and considering the fact that one needs a reliable dataset in order to map and analyse trends nationwide, this study explores the patterns and dimensions of killings by the security forces using graphs and maps generated from data collated from the Nigeria Watch database. The focus is on the dynamics of killings by the security forces, and this raises several important questions for this study: First, what are the main features of security forces killings in Nigeria? This question also relates to the timing of major national events such as elections, when the security forces usually cause fatalities. Second, in terms of perpetrators, which security institution is more involved in security forces killings? Third, are security forces killings more prevalent in the North or the South, and why? These questions are examined in the three main sections of this paper.

Following an outline of the paper, a description of the general context of security forces killings in Nigeria is provided. Thereafter, we proceed to the second section of this paper and categorize the distribution of data relating to fatalities caused by the security forces between 1 June 2006 and 31 May 2014, in order to address the second question of the study. The objective here is to present statistical data in order to determine the major institutions involved in security forces killings. In order to address the third question of the study, the statistical data were disaggregated according to states and supplemented with a security map in order to determine regional differences in the prevalence of security forces kill-

1 Ebohon, S.I. \& E.U.B. Ifeadi (2012), Managing the Problems of Public Order and Internal security in Nigeria. African Security 5(1): 1-23. Available at http://dx.doi.org/10.1080/19392206.2012.653304. Accessed 18 August 2015. 
ings in relation to the North and the South. The statistical data was further disaggregated and classified by period in order to analyse patterns of security forces killings during general elections. The concluding section highlights the major findings based on the overall statistical and empirical content of the information and data analysed.

\section{The security forces and incidents of violent deaths}

Killings of criminal suspects and innocents citizens by the security forces in Nigeria are reported in the media almost on a daily basis. ${ }^{2}$ Historically, law enforcement in the country has been characterized by violence and extra-judicial killings. Since its origin as a 'consular guard', whose primary function was to protect the economic and political interests of the colonial authority, the security forces have continued to use excessive force, including arbitrary killings, in their engagement with the civilian population. ${ }^{3}$ In the immediate post-colonial period the repressive character of the security forces was heightened as a result of the militarization of internal security during military rule, when the army, police, and paramilitary forces were used to repress and kill people arbitrarily. ${ }^{4}$ Since the end of military rule in 1999, successive civilian governments have militarized law enforcement by routinely deploying the army for internal security operations.

Over the years, various Joint Security Task Forces (JTFs) have been created and deployed for internal security duties as a result of the inability of the police to effectively combat the rising wave of organized crime, militancy, and insurgency in the country. ${ }^{5}$ Members of these task forces, who are usually drawn from the Nigerian army, navy, air force, police, State Security Service (SSS), Department of State Security (DSS), and immigration and customs officials, often act like occupying forces against the civilian population, killing people arbitrarily. The security forces rarely adhere to legally mandated rules of engagement, and they are known to use excessive force to arrest, detain, and kill anyone who happens to be at the wrong place at the wrong time. ${ }^{6}$

2 Pérouse de Montclos, M.-A. (2014), Nigeria Watch: Fourth Report on Violence in Nigeria (20062014), p. 6. Available at http://www.nigeriawatch.org/media/html/NGA-Watch-Report14.pdf.

3 Alemika, E. (1993), Colonialism, State and Policing in Nigeria, Law and Social Change 20(3): 187219.

4 Alao, A. (2010) Security Reform in Democratic Nigeria. Conflict, Security and Development, Working Paper, No. 2, pp. 1-52. Available at http://www.securityanddevelopment.org/pdf/work2.pdf.

5 Francis, P., D. LaPin \& P. Rossiasco (2011), Securing Development and Peace in the Niger Delta: A Social and Conflict Analysis for Change. Woodrow Wilson International Centre for Scholars, Washington DC.

6 Afeno, S. Odomovo (2012), The Boko Haram Uprising and Insecurity in Nigeria: Intelligence Failure or Bad Governance? Conflict Trend, Issue 1, pp. 35-41. Available at: http://www.accord.org.za/downloads/ct/ACCORD-conflict-trends-2012-1.pdf. 
Although some of the victims are criminal suspects, others are innocent individuals who are killed either because of politics, or extortion of bribes, or other pecuniary reasons. The security forces, notably the police and army, routinely mount roadblocks and checkpoints on major highways in order to forcefully extort bribes from commuters. Forceful extortion of bribes on the highways often results in incidents of accidental or intentional killings. Moreover, security forces often respond to civil unrest, including protests and riots, with excessive force, which frequently results in deaths. It is remarkable that killings by the security forces are often counted as evidence of effective counter-insurgency and policing, ${ }^{7}$ as is evidenced in the public display of criminal suspects killed by the security forces. Perhaps the violent character of law enforcement in the country is a reflection of the history and social environment of the security forces. Certainly, the political influence, economic background, and 'self-esteem' of the security forces determine their actual behaviour and the level of security they provide for 'the ordinary people'. ${ }^{8}$ Hence, the dynamics of killings by the security forces may be better understood when examined within their changing political, legal, economic, and social contexts.

\section{Political context}

In Nigeria, 'national security' is equated with 'state security', and 'state security' is viewed as the security of political office holders. ${ }^{9}$ Consequently, the security forces are organized and managed to protect the politically influential and the rich by using state violence against other sections of the population. ${ }^{10}$ Moreover, certain political values are attached to state violence, ${ }^{11}$ especially during elections to public office. Political patronage and the use of political power to gain access to wealth promote political violence. Competition for political power is closely associated with the buying and selling of votes and politically motivated killings during elections. ${ }^{12}$ In addition, the so-called security votes - a security fund reserved for the political executive - is often appropriated simply by 'evoking na-

\footnotetext{
NOPRIN (2007), Criminal Force? An Interim Report on the Nigeria Police Force. Network on Police Reform in Nigeria (NOPRIN), Lagos.

8 Mehler, A. (2009), The Production of Insecurity by African Security Forces: Insights from Liberia and the Central African Republic. German Institute of Global and Area Studies. Available at http://repec.giga-hamburg.de/pdf/giga_09_wp114_mehler.pdf.

9 Ibeanu O. \& A. Momoh (2008), State Responsiveness to Public Security Needs. Nigeria Country Case Study produced for the project on 'The Politics of Security Decision-Making'. Available at https://www.academia.edu/1944700/State_Responsiveness_to_Public_Security_Needs_The_Politics_ of_Public_Security_Decision-Making___Nigeria_Country_Study.

10 Pearce, J., R. McGee \& J. Wheeler (2011), Violence, Security and Democracy: Perverse Interfaces and their Implications for States and Citizens in the Global South. IDS Working Paper, No.357.

11 Hills, A. (2012), Lost in Translation: Why Nigeria's Police Don't Implement Democratic Reforms, International Affairs 88(4): 739-755.

12 Hill, J.C.N. (2012), Nigeria Since Independence: Forever Fragile? Palgrave Macmillan.
} 
tional security'. ${ }^{13}$ The idea of 'security votes' implicitly promotes state violence, mostly through the security forces, because it often results in the allocation of more funds to political executives and the security forces. As Howe observed, the character and behaviour of the security forces is largely a reflection of 'national political structures and values'. ${ }^{14}$ Hence, the increasing concern of the political leadership with regime and political survival has resulted in widespread killings by the security forces, with near impunity.

\section{Legal context}

In law enforcement, security forces use a form of authorized state coercion, but they do so in 'tense and often emotionally charged interpersonal encounters' with members of the public. ${ }^{15}$ Hence, to avoid abuse of their mandates, security forces are regulated through institutional laws and codes of conduct, including 'rules of engagement', while discharging their duties. In Nigeria, however, the law grants the security forces wide discretionary powers. For instance, the Criminal Code Act permits the security forces, notably the police, to use force in the suppression of civil unrest and the arrest of suspects, and to use 'any reasonable force' to prevent the 'escape of an arrested person'; and in the case of serious crime, it permits them to kill the suspect if he/she cannot be arrested by any means. ${ }^{16}$ Police Order 237 also permits police officers to shoot detainees and suspects who try to escape or evade arrest. ${ }^{17}$

Police officers are never held responsible for their excesses even though the Criminal Procedure Act stipulates that '[a]ny person authorized by law to use force is criminally responsible for any excess, according to the nature and the quality of the act which constitutes the excess'. ${ }^{18}$ Weak institutional accountability measures make oversight of the security forces ineffective. Judicial oversight of security forces is weak largely because the leadership of the security forces prefer internal accountability measures to external oversight bodies. ${ }^{19}$ For instance, the police and the military forces prefer an 'Orderly Room Trial' and a

13 Uwimana, C. \& L. Wawro (2014), Corruption in Nigeria Military and Security Forces: A Weapon in Boko Haram's Hands. Available at http://saharareporters.com/report/corruption-nigerias-military-andsecurity-forces-weapon-boko-haram $\% \mathrm{E} 2 \% 80 \% 99$ s-hands-transparency-inter

14 Howe, M.H. (2001), Ambiguous Order: Military Forces in African States. Boulder, CO: Lynne Rienner Publishers.

15 Harmon, A.R. (2008), When is Police Violence Justified? Northwestern University Law Review 102(3): 1120 .

16 Criminal Code Act (1990), Laws of the Federation of Nigeria. Available at http://nigerianlawguru.com/legislations/STATUTES/CRIMINAL\%20CODE.pdf

17 Force Order No. 237, Rules for Guidance in the Use of Firearms by the Police.

18 Criminal Code Act (1990), 25 (298).

19 Chukwuma, I. (1997), 'The Legal Structure of the Police and Human Rights in Nigeria'. Third World Legal Studies, Vol. 14, Article 4, pp. 40-70. Available at:

http://scholar.valpo.edu/cgi/viewcontent. cgi?article=1024\&context=twls 
'Court Martial', respectively, in trying their erring officers. ${ }^{20}$ Thus, lack of cooperation from the security forces often frustrates the oversight functions of the courts and the National Human Rights Commission (NHRC). In consequence, the repressive laws and weak accountability measures reinforce the ability of the security forces to engage with impunity in arbitrary killings.

\section{Economic context}

Economic factors play a significant role in killings by the security forces in Nigeria. Most security forces violence and killings are driven by vested economic interests. For instance, the security forces have been accused of influencing the continuation of violent instability in the Niger Delta because of their alleged involvement in the oil bunkering business in the area. ${ }^{21}$ Corruption is widespread in Nigeria, and the security forces, and the police in particular, are among the most corrupt public institutions in the country. ${ }^{22}$ Funds meant for funding the security forces are often misappropriated by its leadership and by political executives, leaving the forces ill-equipped and demoralized. ${ }^{23}$ Hence, faced with lack of equipment and very low wages, the security forces indulge in corrupt practices, including forceful extortion of bribes, which often result in human rights abuses and extra-judicial killings. Most security operatives see extortion of bribes as 'a way to earn a living', and ordinary citizens are obliged to pay for every service rendered by the security forces. ${ }^{24}$ Furthermore, the police usually solicit bribes to investigate or discontinue investigation of suspects, and they sometimes kill on behalf of influential individuals. ${ }^{25}$

\section{Social context}

Nigeria is bedevilled by many social challenges that promote widespread killings by the security forces. Poverty and social inequalities can cause ethno-religious conflicts, criminality, and insurgency, all of which result in violent responses by

20 NOPRIN (2007), Criminal Force? An Interim Report on the Nigeria Police Force. Network on Police Reform in Nigeria (NOPRIN), Lagos.

21 Katsouris, C. \& S. Aaron (2013), Nigeria's Criminal Crude: International Options to Combat the Export of Stolen Oil. Chatham House. Available at:

http://www.chathamhouse.org/sites/files/chathamhouse/public/Research/Africa/0913pr_nigeriaoil.pdf.

22 Persson, H. (2014), Nigeria - An Overview of Challenges to Peace and Security. Available at: http://www.foi.se/Documents/Persson, $\% 20$ Nigeria $\% 20$ $\% 20 \mathrm{An} \% 20$ Overview $\% 20$ of $\% 20$ Challenges $\% 20$ to $\% 20$ Peace $\% 20$ and $\% 20$ Security, $\% 202014$.pdf.

23 Uwimana, C. \& L. Wawro (2014), Corruption in Nigeria Military and Security Forces: A Weapon in Boko Haram's Hands. Available at http://saharareporters.com/report/corruption-nigerias-military-andsecurity-forces-weapon-boko-haram $\% \mathrm{E} 2 \% 80 \% 99$ s-hands-transparency-inter

24 Persson, H. (2014), Nigeria: An Overview of Challenges to Peace and Security. Available at: http://www.foi.se/Documents/Persson, $\% 20$ Nigeria $\% 20$ $\% 20 \mathrm{An} \% 20$ Overview\%20of\%20Challenges\%20to\%20Peace \%20and\%20Security,\%202014.pdf.

25 Human Rights Watch (2014), World Report - Nigeria. Available at http://www.hrw.org/worldreport/2014/country-chapters/nigeria. 
the state. ${ }^{26}$ 'To restore order', the security forces often kill more people than are killed at the initial stage of a conflict. ${ }^{27}$ Hence, killings by the security forces are very common in the areas most affected by ethno-religious violence, criminality, militancy, and insurgency. For instance, arbitrary killings by the security forces were very common in the pre-amnesty Niger Delta because of militant activities, while the imposition of emergency rule in the North-East following the Boko Haram insurgency has resulted in widespread killings by the security forces.

\section{Mapping of killings by the security forces}

There is hardly any reliable statistical analysis of trends and patterns of security forces killings across Nigeria. This is partly a result of inconsistencies in both official data and media reports on such killings. Reports by the police and other security agencies rarely give accurate figures and reveal many discrepancies when compared with media reports and individual accounts. ${ }^{28}$ These discrepancies make it very difficult to get the 'actual number of people killed by the police and other security forces' ${ }^{29}$ As a result of the unsystematic recording of crime data, deaths resulting from security forces violence are either under-reported or overstated. ${ }^{30}$ This inconsistency in body count makes it very difficult to reliably analyse trends and patterns of killings by the security forces nationwide. Statistics about security forces killings in Nigeria simply do not provide reliable information for nationwide mapping and analysis. Consequently, it has become difficult to identify major categories of security forces killings, where and when such killings are likely to occur, and whether such killings are decreasing or increasing.

\section{Data and methods}

This study is based on data extracted from the Nigeria Watch database and covers the period between 1 June 2006 and 31 May $2014 .{ }^{31}$ This time frame was

26 Persson, 'Nigeria - An Overview' ; Ebohon, S. \& E. Ifeadi (2012), Managing the Problems of Public Order and Internal Security in Nigeria, African Security 5(1): 1-23. Available at: http://dx.doi.org/10.1080/19392206.2012.653304.

27 Hill, J.C.N. (2012), Nigeria Since Independence: Forever Fragile? Palgrave Macmillan.

28 Pérouse de Montclos, M.-A. (2011), Nigeria Watch: Third Report on Violence in Nigeria (20062011), p. 7. Available at http://www.nigeriawatch.org/media/html/NGA-Watch-Report11(1).pdf.

29 Ojo, O.E. (2010), Boko Haram: Nigeria's Extra-Judicial State. Journal of Sustainable Development in Africa 12(2): 55. Available at:

http://www.jsdafrica.com/Jsda/V12No2_Spring2010_B/PDF/Boko\%20Haram\%20Nigeria's\%20ExtraJudicial $\% 20$ State $\% 20(\mathrm{Ojo})$.pdf.

30 Pérouse de Montclos, M.-A. (2011), Nigeria Watch: Third Report on Violence in Nigeria (20062011), p. 8. Available at http://www.nigeriawatch.org/media/html/NGA-Watch-Report11(1).pdf

31 Nigeria Watch. Available at: www.nigeriawatch.org. 
chosen because the database started in June 2006, and this study seeks to map and analyse the trends of killings by the security forces over an eight-year period. It should therefore be noted that with the exception of the full years 2007 to 2013, data for 2006 and 2014 should be considered in the light of the stated period when data collation and analysis started and ended. The choice of the Nigeria Watch database is based on the understanding that official data, media reports, and individual accounts are largely inconsistent and therefore unreliable. The security forces, especially the police, either under-report or overstate the number of deaths, depending on the occasion; ${ }^{32}$ the press have a tendency to overestimate casualties of security forces violence; and individuals also tend to overstate the number of people killed by the security forces. However, discrepancies in body counts and methodological biases inherent in official data, media reports, and individual accounts are largely mitigated in the Nigeria Watch database, which monitors, compiles, and cross-checks data on violent deaths from several sources for reliability.

The categories 'security forces', 'army', 'police', and 'other security forces' were used to search the database. Here, 'other security forces' includes all Federal and state governmental security and paramilitary forces, excluding the police, army, and JTFs. ${ }^{33}$ The database was also searched through a filter, 'security forces implication', which identifies violent incidents where the involvement of the security forces resulted in at least one death. The data generated were categorized into main protagonists (army, police, or other security forces), causes (crime, political issues, religious issues, etc.), and relations (security forces versus religious groups, political groups, communities, and trade unions). Data collated from the database were used to produce charts and security maps and to generate statistics for trend analysis of killings by the security forces nationwide.

\section{The main security institutions involved in killings}

In general, the Nigerian security forces - including the army, navy, air force, police, SSS, customs, immigration, National Drug Law Enforcement Agency (NDLEA), and Nigeria Security and Civil Defence Corps (NSCDC) - exhibit a culture of violence and kill with impunity. They are often responsible for violent deaths whenever they intervene in any violent incident. ${ }^{34}$ They repeatedly show themselves unable to maintain law and order in violent conflicts; and the more

32 Pérouse de Montclos, M.-A. (2011), Nigeria Watch: Third Report on Violence in Nigeria (20062011). Available at http://www.nigeriawatch.org/media/html/NGA-Watch-Report11(1).pdf.

33 JTFs are combinations of the police and the army in common task forces that can also include other security institutions. For the sake of clarity, it is here considered that press reports on JTFs refer mainly to the police and the army. These task forces are not to be confused with paramilitary militias called 'Civilian JTF' in north-eastern Nigeria.

34 Pérouse de Montclos, M.-A. (2014), Nigeria Watch: Fourth Report on Violence in Nigeria (20062014). Available at http://www.nigeriawatch.org/media/html/NGA-Watch-Report14.pdf. 
they intervene, the more people are killed. ${ }^{35}$ In the majority of conflicts where the security forces intervened, they were responsible for causing many deaths. This is worrisome because the interventions of the security forces result in more rather than fewer fatalities. Figure 6.1 shows the trend in the number of deaths caused by the security forces between June 2006 and May 2014.

Figure 6.1 Number of violent deaths resulting from incidents where the security

forces intervened, per year (June 2006-May 2014)

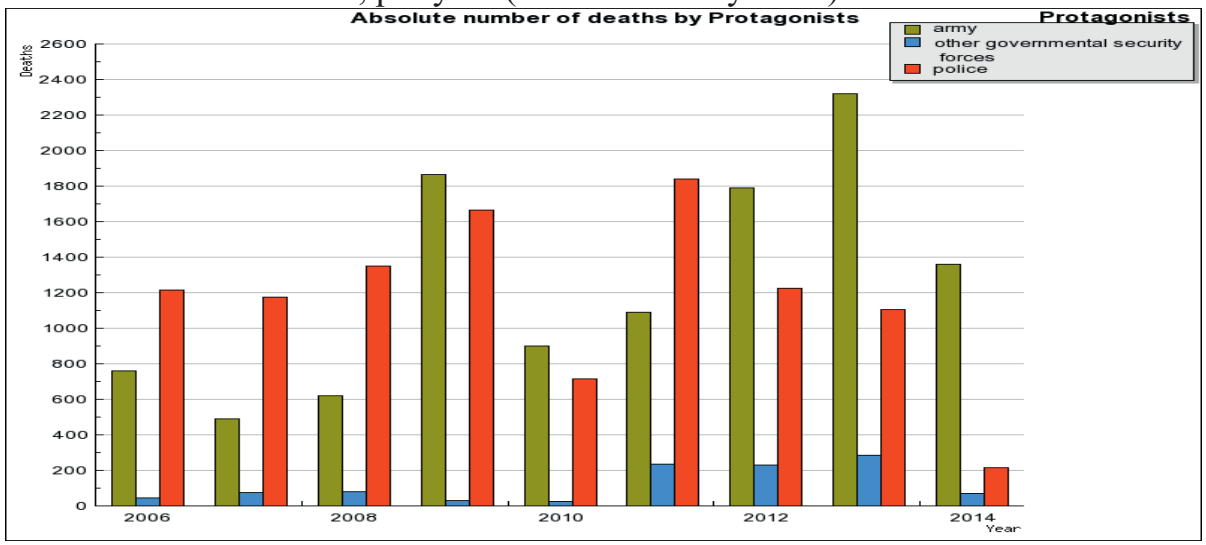

The results show that most of the killings were perpetrated by the police and the army. Between 2006 and 2014, the police caused deaths in 1,560 of 2,694 violent incidents they were involved in, which represents an average of $58 \%$ of their interventions causing deaths. The majority of the fatalities caused by the police resulted from extra-judicial killings. The Legal Defence and Assistance Project of Nigeria recorded 997 and 2,987 extra-judicial killings by the police in 2003 and 2004, respectively. ${ }^{36}$ The proportion is quite similar (60\%) in the case of the army, which killed in 529 out of 880 incidents in which they intervened within the same period. While it is reasonable to argue that most of the killings were caused by the police and the army, other governmental security forces also caused many deaths in their operations. For instance, the 'other security forces' have killed in 119 out of 265 (45\%) incidents in which they were involved. From

35 Hill, Nigeria Since Independence; Peruse de Montclos, M.-A. (2014), Nigeria Watch: Fourth Report on Violence in Nigeria (2006-2014), p. 6. Available at: http://www.nigeriawatch.org/media/html/NGA-Watch-Report14.pdf.

36 Alston, P. (2006) Report of the Special Rapporteur on Extra-Judicial, Summary or Arbitrary Executions: Mission to Nigeria, Geneva, United Nations, Economic and Social Council, Commissioning on Human Rights, 38 pp. 
an annual average of 59\% between June 2006 and May 2007, security forces interventions that resulted in deaths peaked at 80\% between June 2013 and May 2014. This is not unexpected, because the pattern of killings by the security forces has changed since 2013, following the imposition of emergency rule in the North-East in response to the Boko Haram insurgency. However, the pattern is quite systemic, and one can safely argue that these killings 'ha[ve] much to do with a general culture of violence and impunity within the security forces' rather than 'collateral damage'. 37

Many security personnel have also been killed in the course of discharging their duties. Among the security agencies, the police and the army arguably suffered the highest casualty figures. According to Nigeria Police Watch, for instance, a total of 263 police officers were killed on active service in $2009 .{ }^{38}$ The majority of the deaths were caused by armed robbers, while others were killed in violent encounters with Boko Haram insurgents. The year 2013 was particularly deadly for the police, as it recorded very high casualty figures among its officers. According to the Police Officers Wives Association (POWA), 'in the year 2013 alone, 1,585 policemen were killed in the line of duty'. ${ }^{39}$ Although the army does not publicize casualty figures among its officers and the rank and file, the Boko Haram crisis has resulted in many soldiers being killed in the fight against the insurgents. In fact, in August 2014, some soldiers who were angry about the high death toll in the army even rebelled against their commanding officer. ${ }^{40}$

\section{Involvement of the army and police in security forces killings}

The security forces are usually the major protagonists in all incidents where they cause violent deaths. The majority of incidents where the security forces have killed often involve criminal groups, oil companies, and religious, political, and ethnic groups. A closer analysis shows that more people are killed where the security forces are the major actors. Between 2006 and 2014, for instance, the security forces killed in 2,043 incidents, resulting in 12,078 fatalities. However, it would be too simplistic to assume that the magnitude of killings by the security

37 Pérouse de Montclos, M.-A. (2014), Nigeria Watch: Fourth Report on Violence in Nigeria (20062014), p. 7. Available at http://www.nigeriawatch.org/media/html/NGA-Watch-Report14.pdf.

38 Nigeria Police Watch (2011), 263 Police Officers Gunned Down in 2009, Official Says. http://www.nigeriapolicewatch.com/2011/05/263-police-officers-gunned-down-in-2009-official-says/. Accessed 30 September 2014.

39 Otuchikere, C. (2014), Keeping Alive Dreams of Fallen Police Officers' Children, Leadership. http://leadership.ng/features/372674/keeping-alive-dreams-fallen-police-officers-children. Accessed 29 September 2014

40 Sahara Reporters (2014), Near Mutiny at Army Barracks in Maiduguri over High Number of Casualty in Gwoza. http://saharareporters.com/2014/08/07/near-mutiny-army-barracks-maiduguri-over-highnumber-nigerian-troops-casualty-gwoza. Accessed 30 September 2014. 
forces is the same in all violent incidents where they intervene. Ethno-political and religious conflicts are very common, and the intervention of the security forces in these conflicts causes more deaths. ${ }^{41}$ In law enforcement, the police and other security agencies have a tendency to kill rather than arrest and prosecute criminal suspects. ${ }^{42}$ Although the police are the primary institution responsible for law enforcement and internal security, routine deployment of the army for internal security duties has resulted in cases where their encounters with criminals have caused many deaths. In terms of relationship, more people have been killed in violent incidents where the army is involved.

The internal security operations of the army are usually characterized by high fatalities, resulting from excessive use of force. Figure 6.2 represents the major protagonists in incidents where the army and the police intervened and their corresponding number of deaths. The results show that most fatalities caused by the army or its adversaries are recorded in violent conflicts involving religious and political groups. Of course, the army has killed more insurgents and civilians since its engagement with the Boko Haram Islamic group in the North-East. The ideology of the Boko Haram group makes them both an Islamic and a political group; but if it is possible to differentiate between the two types of group, the army appears to cause more deaths in violent incidents involving religious groups. Besides political and religious groups, the intervention of the army in violent conflicts involving communities within the same period resulted in 1,572 fatalities. This shows that the army is more violent in its engagement with the public than the police and that its intervention in violent conflicts often results in more deaths.

Compared with the army, the relationships between the police and political groups, religious associations, trade unions, and host communities appear less violent. However, the involvement of the police in conflicts involving political groups causes more fatalities. Figure 6.2 shows that between June 2006 and May 2014, fatal incidents where the police intervened resulted in 1,332 fatalities when they involved political groups, 877 fatalities when they involved communities, and 612 fatalities when they involved trade unions. Perhaps the politicization of the engagement of the security forces with civilians is responsible for this pattern of large numbers of fatalities in incidents involving political groups.

${ }^{41}$ Hill, Nigeria Since Independence.

42 Serrano, R. \& P. Zacharias (2014), By the Numbers: The Nigerian State's Efforts to Counter Boko Haram. In: M.-A. Pérouse de Montclos, ed., Boko Haram: Islamism, Politics, Security and the State in Nigeria. Leiden: African Studies Centre, p. 207. 
Figure 6.2 Number of violent deaths resulting from incidents where the security forces intervened, by type of relationship (June 2006-May 2014)

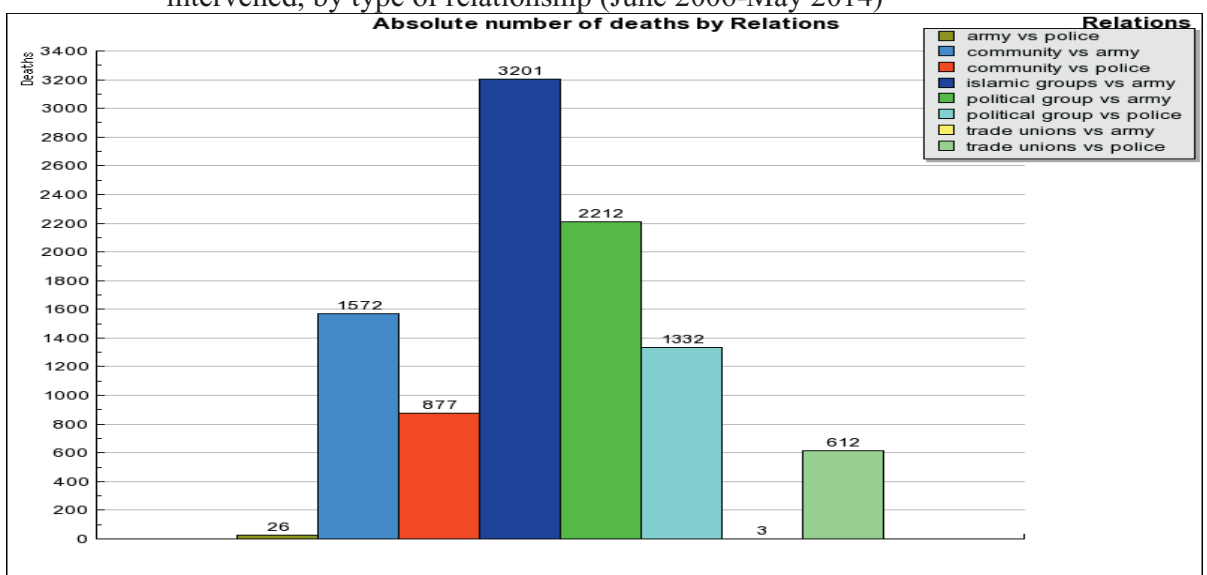

Main protagonists in incidents where the army have caused fatalities

Since 1999, successive civilian governments have established various militarydominated JTFs, under whose auspices the army is routinely deployed for law enforcement and internal security operations. ${ }^{43}$ Unfortunately, the internal security operations of the army are usually characterized by the use of disproportionate force, causing high civilian fatalities. Since 2006, the intervention of the army in violent conflicts involving the police, communities, trade unions, political groups, and religious associations has caused very many deaths. A total of 7,648 fatalities were recorded in 529 out of a total of 880 lethal incidents where the army was involved. This translates to an average of $60 \%$ of all army interventions causing fatalities. Figure 6.3 presents the distribution of these incidents over the years under study.

43 Francis, P., D. LaPin \& P. Rossiasco (2011), Securing Development and Peace in the Niger Delta: A Social and Conflict Analysis for Change. Woodrow Wilson International Centre for Scholars, Washington DC. 
Figure 6.3 Number of violent deaths resulting from incidents where the army intervened, per year (June 2006- May 2014)

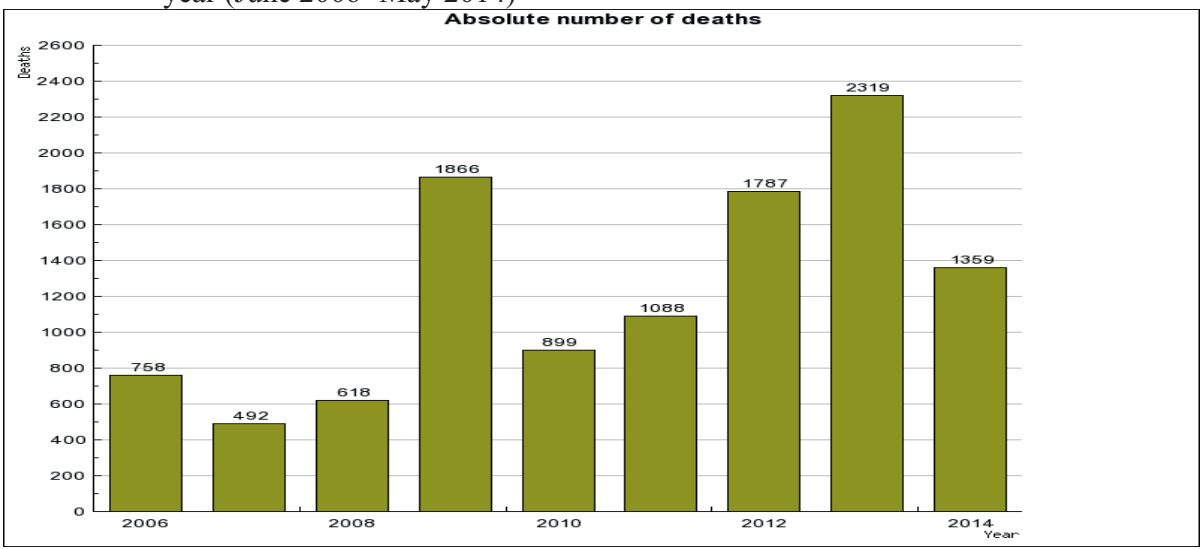

The result shows a noticeable increase in the number of fatalities caused by the army in 2009, 2012, and 2013. The high fatality figures in 2009 can be explained by the deployment of military forces to combat Boko Haram in the North-East and militant groups in the Niger Delta. In May 2009, a combined force of army, air force, and navy personnel bombarded seven communities suspected of harbouring militant camps in Delta State, killing over 500 people. $^{44}$ However, there was a downward trend in killings by the army in 2010, with a steady increase in the following years and a peak when emergency rule was established in the North-East in 2013. In April 2013, for instance, approximately 185 civilians were killed in a military operation against Boko Haram insurgents in Borno. Although it appears the army caused more fatalities in 2013, a critical look at 2014 reveals a sharp increase in fatalities within the first five months. The trend is alarming and the number of victims reached a total of 5,045 by the end the year.

These results do not provide information about the major actors involved in such incidents. However, Figure 6.2 shows that within the period examined in this study, military interventions caused a significant number of fatalities in clashes involving Islamic groups, political groups, and communities, as well as in inter-agency conflicts with the police. The relationship between the army and Islamic groups is particularly deadly. Between June 2006 and May 2014, violent conflicts involving the army and Islamic groups, especially the Boko Haram sect, have caused 3,152 fatalities. The relations between the army and political groups are equally very violent, causing 2,212 fatalities within the same period. While it appears that the relation between the army and Islamic groups is more deadly

44 Ibid. p. 200. 
than other of its relations, it would be too simplistic to assume that the relation between the army and political groups is less violent, because it is often difficult to differentiate between the two groups. For instance, the ideology of the Boko Haram Islamic sect presents them as both a religious and political group.

\section{Main protagonists in incidents where the police have caused fatalities}

Clashes between the army and police are another problem, even if they are less deadly (26 fatalities within eight years). In theory, the involvement of the army in internal security is supposed to supplement the efforts of the police in maintaining public order. It is not to create unnecessary rivalry to the extent of causing fatalities. As the primary institution responsible for law enforcement and internal security, the police actually intervene in many violent conflicts involving diverse groups. Most of these interventions cause fatalities. In 1,560 of 2,704 lethal incidents where it intervened, the police were responsible for killings resulting in a total of 5,851 deaths between June 2006 and May 2014.

Figure 6.4 Number of violent deaths resulting from incidents where the police intervened, per year (June 2006-May 2014

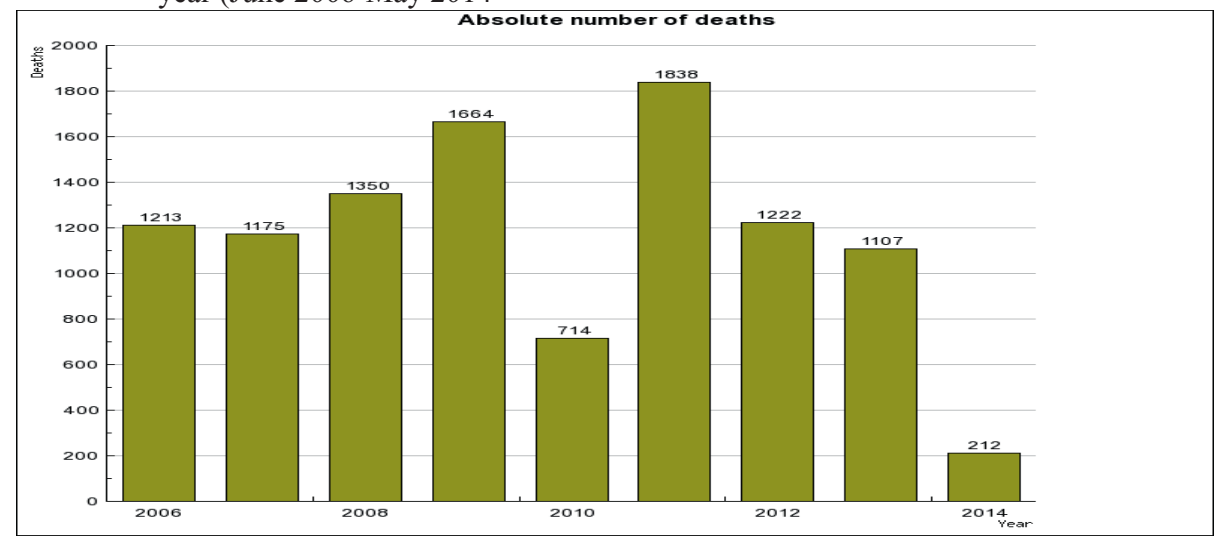

Figure 6.4 indicates an increasing trend of killings by the police between 2006 and 2009 and a significant decrease in fatalities in 2010. The active involvement of the army in internal security, as a result of the inability of the police to effectively combat the menace of insurgency, is the most likely explanation for the observable decrease in fatalities caused by the police in 2010. A critical look at Figure 6.3 above shows that the sharp decrease in police killings in 2010 was followed by a corresponding increase in fatalities caused by the army in the same year. The army caused 899 fatalities compared with 714 fatalities caused by the 
police in the same year. At the time, after the leader of the Boko Haram sect, Mohammed Yusuf, was extra-judicially executed by the police in July 2009, the sect regrouped under a more radical leader, Abubakar Shekau, under whose leadership the group began to carry out more violent attacks, including targeted killings and suicide bombings. ${ }^{45}$ This development compelled the Federal Government to deploy special military task forces to combat the insurgents, and this significantly reduced the involvement of the police in the counter-insurgency operations in the affected states.

However, killings by the police peaked in 2011, during violent incidents that caused 1,838 fatalities. This translates to a $39 \%$ increase from the 714 fatalities in the previous year. Perhaps the significant increase in killings by the police in 2011 may be explained by the fact that it was an election year, and the 2011 general election was adjudged one of the most violent in the history of the country. ${ }^{46}$ The presidential election, in particular, was followed by post-election protests and riots that degenerated into sectarian and ethnic clashes in which the police intervened. It will not be necessary here to go into the details of killings by the security forces during the 2011 general elections since it is examined in a later section of the study. Furthermore, since 2012 there has been a steady decrease in the number of fatalities caused by the police. Again, a close look at Figures 6.3 and 6.5 shows that the reduction in the number of fatalities caused by the police since 2012 is followed by a corresponding increase in the number of fatalities caused by the army in the same period. Between 2012 and the first five months of 2014, the army caused a cumulative fatality figure of 5,465 compared with 2,541 fatalities caused by the police within the same period. However, this result does not provide detailed information about the major groups involved in incidents where the police caused fatalities. Figure 6.5 examines the relational factors in incidents where the police have caused fatalities.

In terms of fatalities, the relation between the police and political groups when compared with other groups appears to be the most deadly. Figure 6.5 indicates that between June 2006 and May 2014, incidents involving the police and political groups caused 1,332 fatalities compared with 877 and 612 fatalities in incidents where the police confronted communities and trade unions, respectively. Important information in this graph is that the police cause more fatalities in incidents involving political issues than in routine law enforcement. If we assume that one can use the number of fatalities to determine the level of encounter between the police and a particular group, then it can be argued that the police in-

45 Integrated Regional Information Network (IRIN) News (2013), Updated Timeline of Boko Haram Attacks and Related Violence. Available at http://www.irinnews.org/printreport.aspx?reportid=99319. Accessed 16 December 2013.

46 Human Rights Watch (2011), Nigeria: Post-Election Violence Killed 800. Available at http://www.hrw.org/news/2011/05/16/nigeria-post-election-violence-killed-800. 
tervene more in violent incidents involving political groups than in incidents involving communities and criminal groups. The impression is that the police are largely organized and managed to protect the politically influential by using state violence against other sections of the population. ${ }^{47}$ It may be the case, however, that the police do not intervene more in political violence, only that their intervention in incidents involving political groups is more deadly.

Figure 6.5 Number of violent deaths resulting from incidents where the police intervened, by type of relationship (June 2006-May 2014)

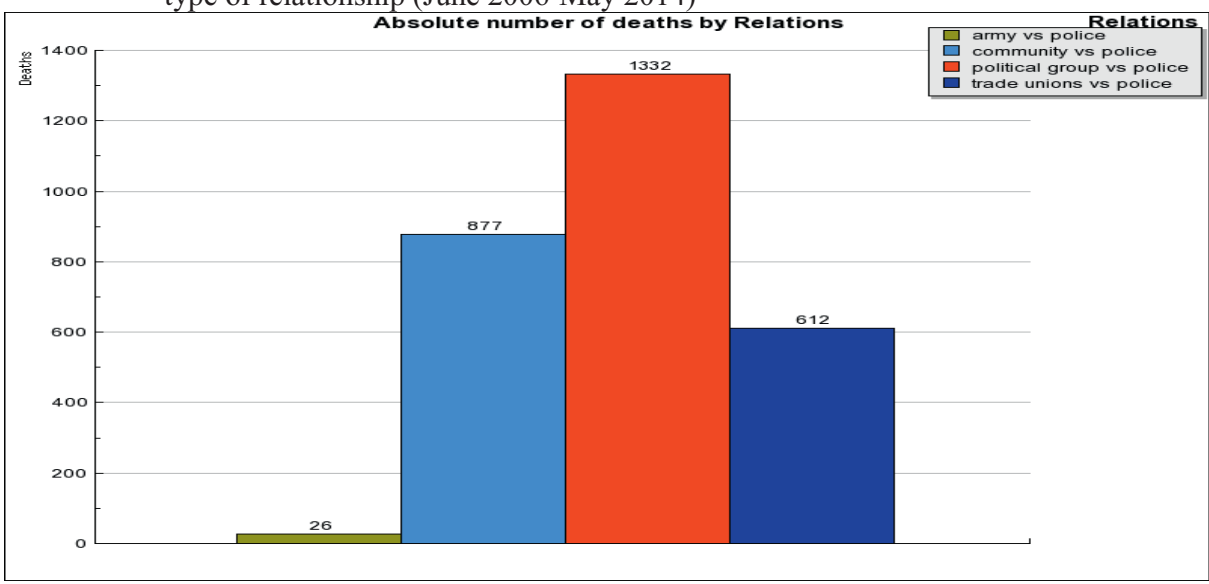

\section{Regional differences in security forces killings}

The causal and relational explanations of killings by the security forces provided in previous sections of this study indicate that the majority of the fatalities resulted from attempts by security operatives to restore public order during crises. Hence, such killings are likely to be more prevalent in regions that are prone to violent conflicts. However, it is important that we analyse the fatality figures across all the states in order to determine the states where the security forces cause more fatalities. A state-by-state analysis of the fatality figures will also enable us determine regional differences in killings by the security forces. A mapping of the number of fatalities caused by the security forces based on data collated from the Nigeria Watch database from June 2006 to May 2014 is presented in Map 6.1. The Map shows that the security forces caused more fatalities in the northern part of Nigeria. During the period under review, however, incidents involving the security forces, causing a total of more than a thousand fatalities,

47 Pearce, J., R. McGee \& J. Wheeler (2011), Violence, Security and Democracy: Perverse Interfaces and Their Implications for States and Citizens in the Global South. IDS Working Paper, No. 357. 
were recorded in six states nationwide: Borno, Plateau, Lagos, Delta, Rivers, and Anambra. Furthermore, the majority of these states are located in the South (Lagos, Delta, Rivers, and Anambra).

Map 6.1 Fatalities resulting from incidents where the security forces intervened in Nigeria (June 2006-May 2014)

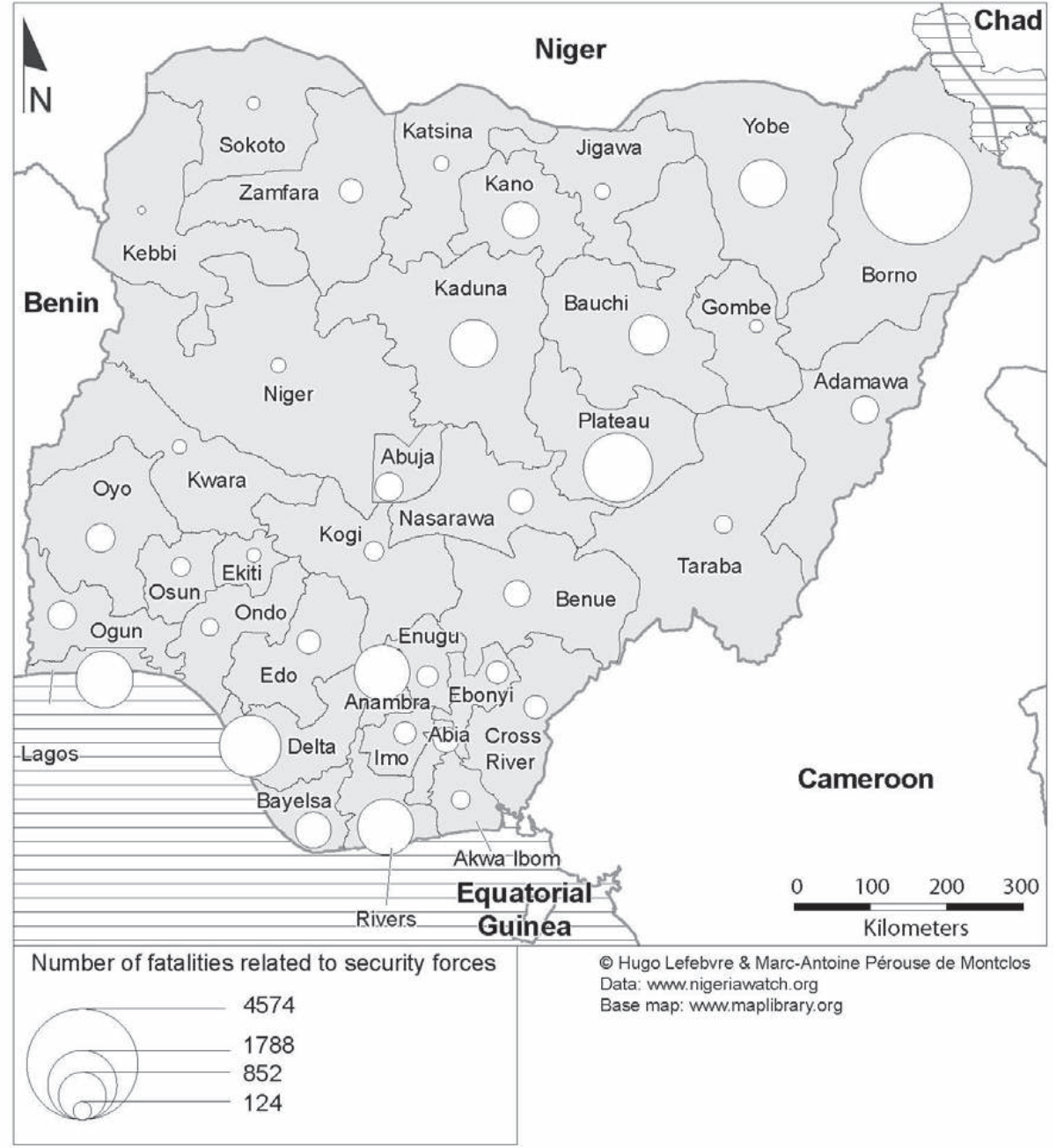

At the state level Map 6.1 shows that incidents involving the security forces have caused more fatalities in Borno than in any other state. The alarming fatality figure $(4,569$ deaths) recorded in the state was largely the result of the interven- 
tion of the security forces, notably the army, in the deadly Boko Haram insurgency. The counter-insurgency operations of the army took a very violent dimension after the imposition of emergency rule in the North-East in May 2013. However, the security forces, notably the army, also caused hundreds of fatalities in a series of violent encounters with the Islamic sect before the imposition of emergency rule. In a widely condemned operation against members of the sect in Baga in April 2013, the army under the auspices of the Multi-National Joint Task Force (MNJTF) killed 185 people, many of them civilians. ${ }^{48}$ Since the declaration of emergency rule, the spate of killings by the security forces has assumed a worrying dimension in the state, as the army often issues accounts of scores of insurgents killed almost on a daily basis. ${ }^{49}$

In the North Central region, the intervention of the security forces in the lingering sectarian and ethnic conflicts in Plateau State has caused many fatalities. The Nigeria Watch database recorded 1,784 fatalities in incidents involving the security forces in the state between June 2006 and May 2014. The intervention of the security forces in the mainly ethno-sectarian crises that have occurred in this state has usually been very violent. In November 2008, for instance, the army and police caused more than 130 fatalities while repressing ethno-sectarian and political violence in Jos. ${ }^{50}$ In a similar development in July 2012, the security forces killed more than 20 Fulani militiamen who had earlier attacked some communities and killed many people, including Senator Gyang Dantong and Assemblyman Gyang Fulani. The Plateau experience exemplifies situations where the involvement of the security forces in violent conflicts results in increased fatalities.

In the South-West, the security forces have caused more fatalities in Lagos State than in any other state in the region. Between June 2006 and May 2014, incidents involving the security forces caused 1,195 fatalities in the state. As the commercial hub and one of the most populous states in the country, Lagos is a haven for social miscreants, including armed robbers whose engagement with the security forces often results in violent deaths. Clashes between smugglers and customs officers, as well as violent confrontations among personnel of the various security agencies, often result in high fatality figures. In May 2011, for instance, soldiers killed four police officers, including a Divisional Police Officer (DPO) and a Divisional Crime Officer (DCO), to avenge the death of their col-

48 Integrated Regional Information Network (IRIN) News (2013), Updated Timeline of Boko Haram Attacks and Related Violence. http://www.irinnews.org/printreport.aspx?reportid=99319. Accessed 16 December 2013.

49 Monguno, H. (2013), Terrorism, Security and Fifth Columnists. Leadership (Nigeria), 29 October 2013, p. 34.

50 Human Rights Watch (2009), Arbitrary Killings by the Security Forces, Submission to the Investigative Bodies on the November 28-29, 2008 Violence in Jos, Plateau State, Nigeria. http://www.hrw.org/sites/default/files/reports/nigeria0709web.pdf. Accessed 9 September 2014. 
league who was killed by policemen at a checkpoint while he was escorting a vehicle conveying goods across the Nigerian border with the Republic of Benin. ${ }^{51}$ Although most security forces killings in the state are related to criminals, there are instances where innocent people have been killed either accidentally or intentionally. Many fatalities have resulted from stray bullets fired by security personnel, mostly during encounters with criminal gangs in the state.

In the South-East the majority of the killings by the security forces are related to political and criminal issues, and a greater proportion of this violence occurred in Anambra State. From June 2006 to May 2014, incidents involving the security forces caused 1,150 fatalities in the state. The majority of these deaths occurred in violent incidents involving criminal gangs and political groups in the commercial city of Onitsha. The city is notorious for violent incidents involving the security forces, trade unions, criminal gangs, and political groups.

Apart from criminal groups, the relationship between the security forces and the Movement for the Actualisation of the Sovereign State of Biafra (MASSOB) has been very violent. From June 2006 to December 2013, clashes between the security forces and supporters of MASSOB caused over 800 fatalities. In June 2006, for instance, 16 people were shot dead when security forces raided MASSOB offices in the state. ${ }^{52}$ In a related incident, the intervention of the security forces in clashes between supporters of MASSOB and members of the National Association of Road Transport Owners (NARTO) between June and July 2006 caused over 700 fatalities in Onitsha. ${ }^{53}$ Perhaps the status of Onitsha as an important trading centre and gateway to the South-East makes it susceptible to violent incidents, which often involve the security forces.

In the Niger Delta region, the involvement of the security forces in violent incidents was remarkably deadly in Delta and Rivers states. The operations of the various security task forces which are mandated to combat militancy, illegal oil bunkering, and piracy in the Niger Delta area have always been very violent. In May 2009, over 500 people were killed in a coordinated attack by a combined team of army, navy, and air force personnel in Gbaramatu kingdom of Delta State. ${ }^{54}$ In Rivers State, killings by the security forces are largely related to political issues and criminal activities, including oil wars. In September 2008, for instance, JTF operatives invaded approximately seven communities in search of

51 DPO's Murder: Policemen Desert Badagry Checkpoints, ThisDay.

http://www.thisdaylive.com/articles/dpo-s-murder-policemen-desert-badagry-checkpoints/92072/. Accessed 9 September 2014.

52 Onuchukwu, B. (2012), Security Personnel Raided MASSOB Offices, Kill 16. Daily Trust. http://www.nigeriawatch.org/media/doc_acc/DT2012-06-06p12.pdf. Accessed 9 September 2014.

53 See Nigeria Watch Database. http://ngw-opsis//index.php?urlaction=evtView\&id_evt=16\&rang=74. Accessed 9 September 2014.

54 Francis, LaPin \& Rossiasco, Securing Development and Peace, p. 200. 
Farah Dagogo, a factional leader of MEND, and killed more than 70 people, including innocent residents. ${ }^{55}$

Geopolitically, the security map in Map 6.1 shows that the security forces were most violent in the North-East, followed by the North Central, South-South, South-West, and South-East regions, based on cumulative fatality figures. However, Map 6.1 does not provide us with enough information to determine in which place security forces violence is more frequent. Figure 6.6 presents the frequency of incidents where the security forces have caused fatalities in selected states from the six geo-political regions of the country. The graph shows that cases where the security forces cause fatalities are more frequent in Lagos than in any other state. However, based on information shown in Figure 6.6, it appears that the security forces caused fewer fatalities in each violent incident in which they intervened in the state. This implies that although the security forces are usually involved in many violent incidents in Lagos, their intervention results in fewer fatalities when compared with states such as Borno and Delta, where the security forces have caused more fatalities. This may be explained by the fact that the security forces in Lagos avoid extra-judicial killings because they are more scrutinized by human rights organizations. Moreover, violent incidents in Lagos are largely related to criminal gangs, where the police usually intervene, causing fewer fatalities than cases involving the army.

Figure 6.6 Frequency of security forces killings in selected states (June 2006-May 2014)

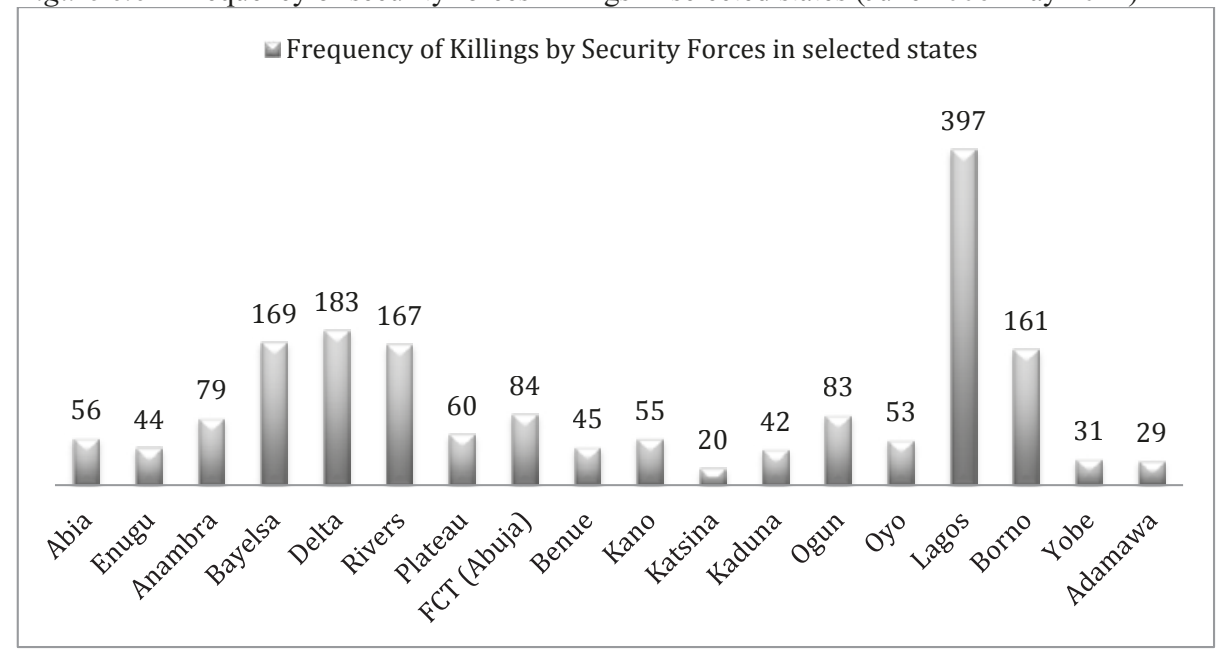

55 Ibanga, I. et al. (2008), 100 People Feared Killed as Oil War Enters Second Day. Punch. http://www.nigeriawatch.org/media/doc_acc/P2008-09-16b.pdf. Accessed 8 September 2014. 
A critical look at Figure 6.6 also shows that killings by the security forces are more frequent in the Niger Delta states of Bayelsa, Delta, and Rivers than in the north-eastern states of Borno, Adamawa, and Yobe, where the security forces are currently involved in the fight against Boko Haram insurgents. The pervasiveness of security forces killings in the Niger Delta may not be unconnected with gang wars, oil bunkering, political violence, armed robbery, kidnapping, and the now abated militancy. The involvement of the security forces in organized criminal and political violence in most states in the Niger Delta often causes more fatalities per incident because the army are usually involved, and they are known for using excessive force.

Although Figure 6.6 indicates the frequency of violent incidents by state where the security forces cause fatalities, it does not provide enough information to help determine the specific security agency that causes more deaths in each state. Figure 6.7 therefore presents the frequency of the involvement of each of the major security agencies in incidents that result in fatalities.

Figure 6.7 Frequency of security forces killings, by perpetrators, in selected states (June 2006-May 2014)

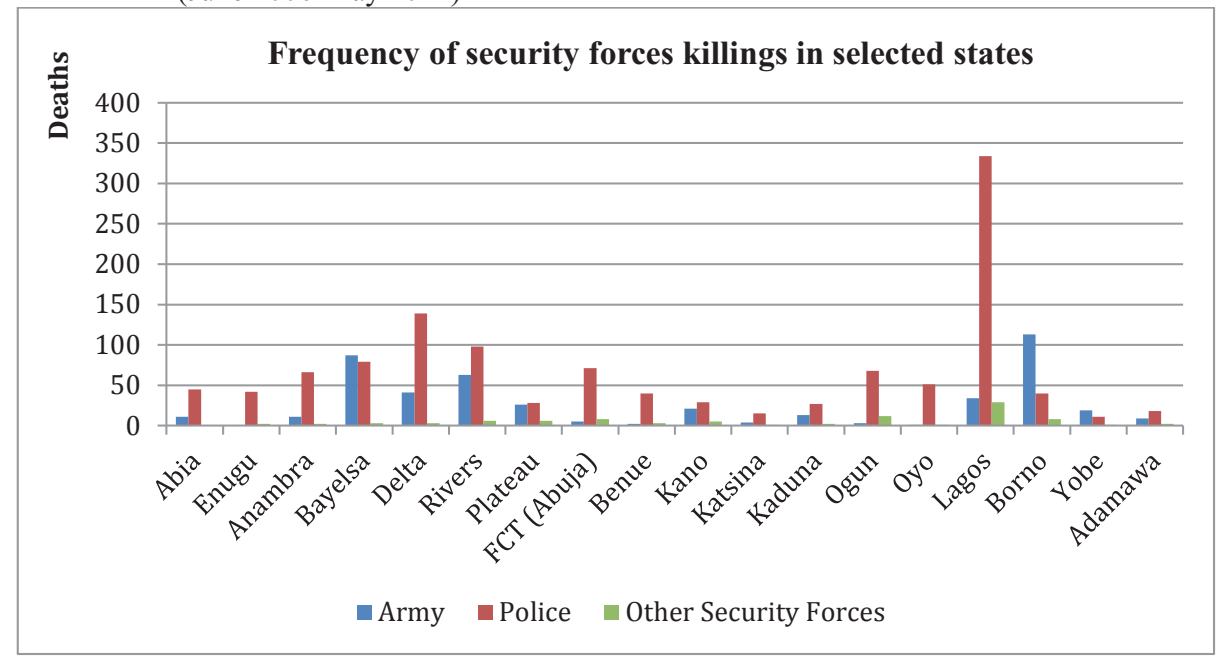

Figure 6.7 shows that killings by the police are by far the most frequent nationwide. With the exception of Bayelsa, Borno, and Yobe states, where there is the strong presence of the army-dominated JTFs, killings by the police are most frequent in every other state where killings by the security forces are widespread. However, there is no major difference in the frequency of killings by the police and army in Plateau State. This may be explained by the fact that the main securi- 
ty outfit in the state, the Special Task Force (STF), comprises personnel from both the army and the police force. There are, however, a significant number of killings involving the 'other security forces' in Lagos State.

The next section of the study examines some ad hoc case studies to illustrate the trend and patterns of killings by the security forces.

\section{Ad hoc cases of killings by the security forces}

Relevant ad hoc case studies will be helpful in illustrating the 'growing preference among the Nigerian security forces to kill'. ${ }^{56}$ Two cases are presented to illustrate how the intervention of the security forces in violent incidents often results in more deaths. Case 1 looks at how the intervention by a team of army and police personnel in a violent conflict between supporters of MASSOB and members of NARTO caused many more fatalities than were recorded at the initial state of the conflict. In Case 2, the study uses two deadly military operations in Baga town and Giwa Barracks, both in Borno State, to illustrate how the security forces use human fatalities to determine the success or failure of their internal security operations.

\section{Case 1: A deadly intervention}

In March 2006, dozens of MASSOB activists were killed by the police in Anambra State following a campaign by the group to boycott the 2006 population census. MASSOB was formed in 1999 by a lawyer-cum-secessionist activist, Ralph Uwazurike, to actualize the dream of an independent state of Biafra after the civil war of 1967-1970. However, the anti-government stance of the group often pitched it against the security forces. Clashes between supporters of the movement and the security forces have always been deadly. In one of the most violent encounters between MASSOB and the security forces, many supporters of the group were killed. The crisis started after two weeks of violent clashes between MASSOB activists and NARTO members, which resulted in the burning of two police stations and a major prison in the state. Approximately 200 prisoners were allegedly set free, and scores of people were killed. ${ }^{57}$ Both groups accused the other of destroying the prison and releasing the prisoners, and thereafter engaged one another in a proxy war.

Following a series of street battles between the two groups, the police intervened by raiding MASSOB offices in Onitsha and caused many fatalities among members of the group. Subsequently, the Federal Government deployed soldiers

56 Serrano, R. \& P. Zacharias (2014), By the Numbers: The Nigerian State's Efforts to Counter Boko Haram. In: M.-A. Pérouse de Montclos, ed., Boko Haram: Islamism, Politics, Security and the State in Nigeria. Leiden: African Studies Centre, p. 207.

57 IRIN News (2006), Nigeria: Government Cracks Down on Biafra Separatist Resurgence. 4 September 2006. http://www.irinnews.org/printreport.aspx?ReportId=60795. Accessed 10 September 2014. 
to help the police restore law and order. This was followed by a declaration of a dusk-to-dawn curfew by the state government. During the ensuing violent confrontation between the security forces and supporters of the group, '[m]any people found with guns or MASSOB identity cards' were summarily executed during cordon-and-search operations in Onitsha. ${ }^{58}$ The involvement of the security forces in that violent incident resulted in more deaths by far than were recorded in the initial clashes between MASSOB and NARTO members. At the last count, the intervention of the security forces caused over 700 deaths in the conflict, mainly through summary executions. ${ }^{59}$

\section{Case 2: Killings as a yardstick}

Fatality figures have become a key yardstick used by the security forces to measure the effectiveness of their operations. The police are known to publicly display the corpses of armed robbery suspects as evidence of effective policing. More recently, the JTFs have formed the habit of claiming success in the fight against insurgency based on the number of insurgents they kill in each operation. ${ }^{60} \mathrm{Al}-$ most everyone killed by the security forces is now classified either as a criminal or an insurgent. In a widely condemned military operation against Boko Haram insurgents in April 2013, soldiers under the auspices of the MNJTF caused an estimated 185 fatalities and devastated the entire town of Baga in Borno State. ${ }^{61}$ The leadership of the MNJTF later claimed that those killed were either Boko Haram members or individuals associated with the sect.

In a similar incident in March 2014, the JTF killed over 200 people when suspected Boko Haram insurgents attempted to release a number of their members from a detention centre in the Giwa military barracks in Borno State. Notwithstanding the high number of avoidable deaths that were caused by the army, the defence headquarters claimed the operation was a success. While commenting on the military operation, the Director of Defence Information, Major General Chris Olukolade, stated that the attack by the insurgents 'ha[d] been successfully repelled with heavy human casualties on the terrorists'. ${ }^{62}$ As the comment indicates, military operations that devastate entire communities and result in high civilian fatalities are celebrated as accomplished missions. It is worth noting,

58 Ibid.

59 See Nigeria Watch Database. http://ngw-opsis//index.php?urlaction=evtView\&id_evt=16\&rang=74. Accessed 9 September 2014.

60 Monguno, H. (2013), Terrorism, Security and Fifth Columnists. Leadership (Nigeria), 29 October 2013, p. 34.

61 Wisdom, P. ( 2013), 185 Feared Killed in JTF, Boko Haram Clash in Borno. Daily Independent (Nigeria). http://www.dailyindependentnig.com/2013/04/185-feared-killed-in-jtf-boko-haram-clash-inborno/. Accessed 9 July 2013.

62 Mamah, E., K. Omonobi, N. Marama \& B. Agande (2014), 207 Suspected Terrorists Killed as Boko Haram Battle Military in Maiduguri, The Vanguard (Nigeria). http://vanguardngr.com/2014/03/207suspected-terrorists-killed-boko-haram-battle-military-maiduguri/. Accessed 21 May 2014. 
however, that both the attackers and the detainees were killed, so even if the attackers were assumed to be insurgents, it is very likely that some of the detainees were innocent civilians. The military authority later admitted that over 1,400 suspected insurgents were held in that same detention centre for many months without trial. ${ }^{63}$

\section{Security forces killings during elections}

The involvement of the security forces in the conduct of elections is usually characterized by violence, and killings by the security forces are common. In particular, the police have been alleged to collude with politicians to intimidate political opponents and the electorate in order to influence the outcome of elections. The fact that general elections are conducted periodically also means that killings by the security forces during elections are cyclical. Moreover, the political significance of elections also means that such killings will most likely assume a political dimension. In this regard, this section of the study analyses the 2007 and 2011 general elections in Nigeria in order to determine the pattern of killings by the security forces.

\section{The 2007 general elections}

The 2007 elections were no doubt among the most violent in the electoral history of the country. Many people were killed in a series of violent incidents before, during, and after the elections. During the electioneering period that preceded the general elections in April of that year, supporters of the major political parties as well as rival factions of the various parties engaged one another in violent clashes that often involved the security forces. The security forces actively intervened in several pre-election, election-day, and post-election violent incidences that occurred between the end of 2006 and April 2007. Within this period, the Nigeria Watch database recorded 29 fatalities caused by the security forces. These fatalities were recorded from 13 violent incidents in which the security forces intervened during the elections. The majority of these deaths occurred during the gubernatorial/state Houses of Assembly and the presidential/National Assembly elections which took place on 14 April and 21 April 2007, respectively. Figure 6.8 presents the percentages of fatalities caused by the security forces before and during the 2007 general elections.

63 Mutum, R. (2013), Insurgency... Military Admits 1,400 Detained Without Trial, Daily Trust (Nigeria). http://www.dailytrust.com.ng/daily/top-stories/11657-i-n-s-u-r-g-e-n-c-y-military-admits-1-400detained-without-trial. Accessed 20 May 2014. 
Figure 6.8 Percentages per month of the total fatalities caused by the security forces during the 2007 general elections

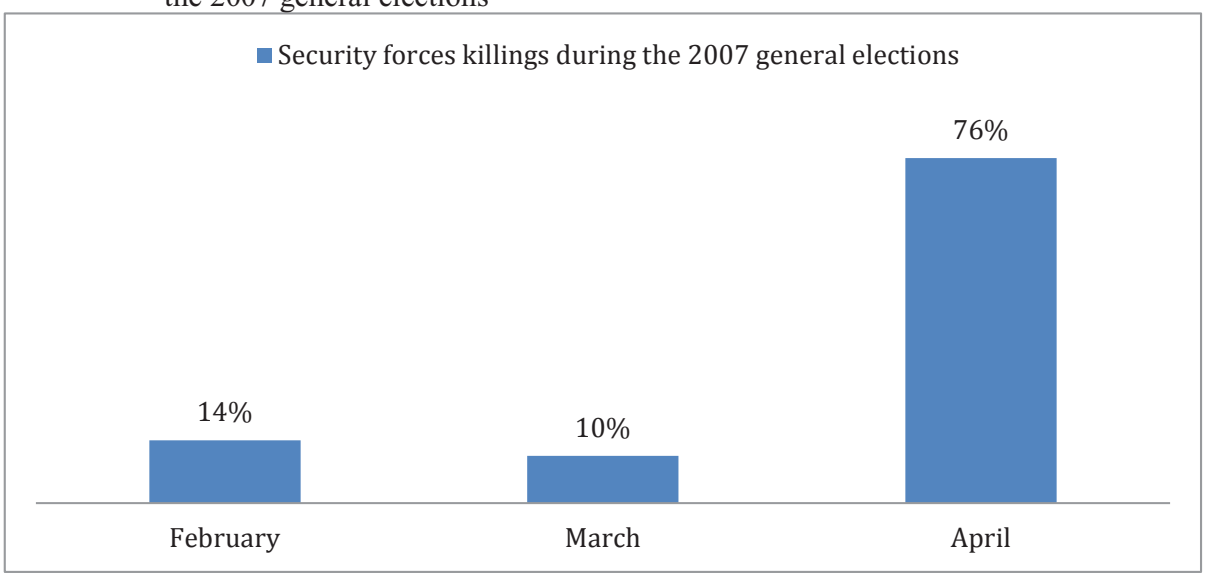

Figure 6.8 shows that $76 \%$ of the fatalities occurred around the election days, while $24 \%$ occurred in the pre-election period. It is worth noting, however, that most of the incidents where the security forces caused deaths involved inter-party violence. As soon as the deadline for the return of nomination forms by political parties elapsed on 29 January 2007, the various political parties became enmeshed in violence. The security forces were actively involved in these violent incidents either through official intervention or as personal guards to party stalwarts and candidates during the campaign and elections periods. According to the National Democratic Institute (NDI), more than 280 election-related deaths were recorded shortly before the 2007 elections. ${ }^{64}$

\section{The 2011 general elections}

Unlike the 2007 elections, the involvement of the security forces in the 2011 elections was well coordinated. The security forces participated in the 2011 general elections under the auspices of the Inter-Agency Consultative Committee on Election Security (ICCES). Through the ICCES the various security agencies were integrated into the security and logistics committees of all the states and LGAs to ensure law and order during the elections. However, the security forces intervention in violent incidents before, during, and after the elections resulted in many deaths. The majority of these killings occurred immediately after the presidential elections. The elections, in which the major presidential candidates came from the predominantly Christian South and Muslim North, led many politicians

64 National Democratic Institute (NDI) (2007), Final NDI Report on the Nigeria's 2007 Elections. https://www.ndi.org/files/2313_ng_report_election07_043008.pdf. Accessed 15 September 2014. 
to leverage their ethnic and religious identities for political advantage, a situation that resulted in widespread post-election violence in parts of the country. ${ }^{65}$ Figure 6.9 presents the percentages of fatalities caused by the security forces during the elections in April 2011 and in each of the three months that preceded the elections that year.

Figure 6.9 Percentages per month of the total fatalities caused by the security forces during the 2011 general elections

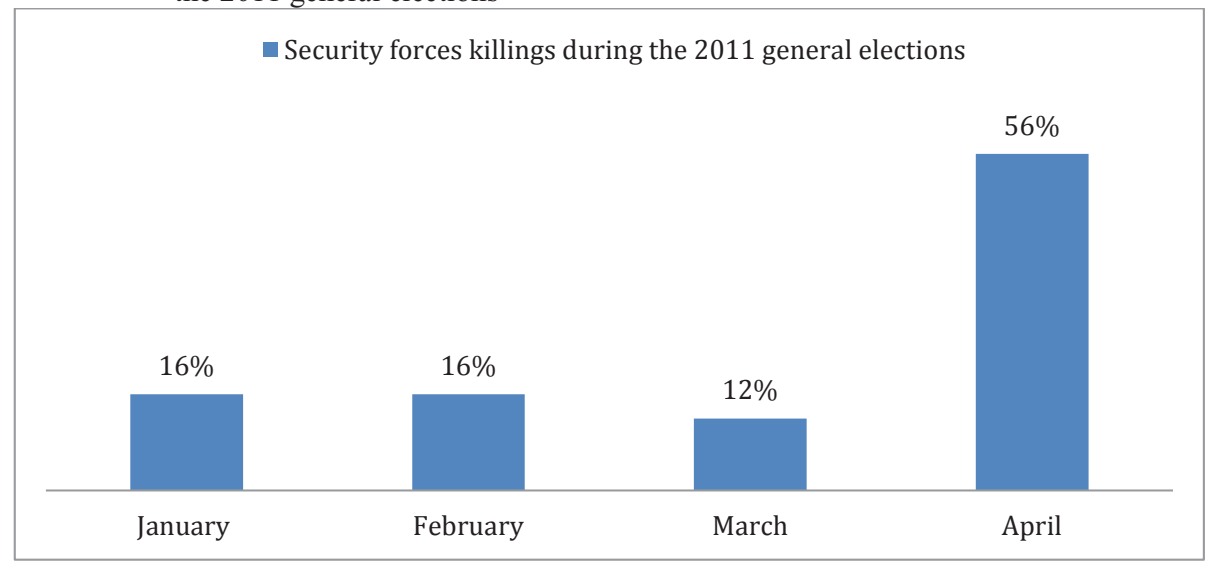

Between January 2011, when the electioneering process climaxed, and April 2011 when the elections took place, the security forces killed 25 people in 9 violent incidents where they intervened. Most of the killings took place immediately after the presidential election on 16 April. Figure 6.9 shows that the majority (56\%) of fatalities caused by the security forces occurred during and immediately after the presidential election, compared with $44 \%$ of the fatalities recorded in the three months that preceded the elections. Inflammatory utterances by some aspirants that had lost the elections resulted in post-election riots, which degenerated into violent assaults, arsons, and killings ${ }^{66}$ In parts of the North, the outcome of the elections, particularly the presidential election, resulted in violent protests, which later degenerated into sectarian and ethnic violence. The intervention of the security forces in the more than three days of post-election violence, especially in the northern cities of Kano and Kaduna, resulted in many fatalities. The pat-

65 Ayoade, J. \& A. Akinsanya, eds, (2013), Nigeria's Critical Election, 2011, Lanham (Md.), Lexington Books.

66 INEC (2013), Report on the 2011 General Elections. http://www.inecnigeria.org/wpcontent/uploads/2013/07/REPORT-ON-THE-2011-GENERAL-ELECTIONS.pdf. Accessed 12 September 2014. 
tern of killings by the security forces during the 2011 elections indicates that the post-election violence was more deadly by far than the election-day and preelection violence. However, in terms of cumulative fatality figures, the involvement of the security forces in the 2007 general elections was more deadly than in the 2011 elections.

\section{Conclusion}

Analysis of the dynamics of security forces killings in Nigeria requires not only an understanding of the role of the security forces as the primary apparatus of state-sanctioned violence; it also requires a knowledge of the general context within which the security establishment operates. Scholarly analysis must recognize the general context, as well as the relational and causal factors that increase security forces killings. This study has established that security forces killings have much to do with a general culture of violence, rather than with the result of accidental deaths or collateral damage. The statistics presented in the paper demonstrate that the majority of incidents where the security forces intervene result in fatalities; and the more they intervene, the more people are killed. The statistics further illustrate that the involvement of the army causes more fatalities per incident, even though killings by the police are more numerous. Further mapping in the paper illustrates that the intervention of the security forces in incidents involving political groups causes more fatalities, but the Boko Haram crisis and the relationship between the army and Islamic groups is the most deadly, causing more fatalities per incident. Lastly, the paper discovered that incidents of killings by the security forces are more prevalent in the southern region but cause more fatalities in the northern region of the country.

\section{References}

AfENO, S.O. (2012), The Boko Haram Uprising and Insecurity in Nigeria: Intelligence Failure or Bad Governance? Conflict Trends 1: 35-41.

ALAO, A. (2000), Security Reform in Democratic Nigeria. Conflict, Security and Development, Working Paper, No. 2, pp. 1-52.

Alemika, O.E. (1993), Colonialism, State and Policing in Nigeria. Crime, Law and Social Change 20(3): 187-219.

ALSTON, P. (2006), Report of the Special Rapporteur on Extra-Judicial, Summary or Arbitrary Executions: Mission to Nigeria. Geneva, United Nations, Economic and Social Council, Commissioning on Human Rights.

ChILUwA, I. (2011), Media Representation of Nigeria's Joint Military Task Forces in the Niger Delta Crisis. International Journal of Humanities and Social Sciences 1(9): 197-208.

Chukwuma, I. (1997), The Legal Structure of the Police and Human Rights in Nigeria. Third World Legal Studies 14, Article 4: 40-70. 
CRIMINAL CODE ACT (1990), Laws of the Federation of Nigeria. http://nigerianlawguru.com/legislations/STATUTES/CRIMINAL\%20CODE.pdf. Accessed 8 August 2014.

EBohon, S. \& E. IfEAdi (2012), Managing the Problems of Public Order and Internal Security in Nigeria, African Security 5(1): 1-23.

Francis, P., D. LAPIN \& P. Rossiasco (2011), Securing Development and Peace in the Niger Delta: A Social and Conflict Analysis for Change. Woodrow Wilson International Centre for Scholars, Washington DC.

HARMON, A.R. (2008), When Is Police Violence Justified?, Northwestern University Law Review 102(3): 1119-1188.

HILL, J.C.N. (2012), Nigeria Since Independence: Forever Fragile? Palgrave Macmillan.

HILLS, A. (2012), Lost in Translation: Why Nigeria's Police Don't Implement Democratic Reforms. International Affairs 88(4): 739-755.

Howe, M.H. (2001), Ambiguous Order: Military Forces in African States, Boulder, CO: Lynne Rienner Publishers.

Human Rights Watch (2005), 'Rest in Pieces' - Police Torture and Deaths in Custody in Nigeria, Human Rights Watch Report', Vol. 17, No. 11 (A). www.hrw.org/reports/2005/nigeria0705.pdf. Accessed 28 July 2013.

HumAN Rights WATCH (2010), Everyone's on the Game: Corruption and Human Rights Abuses by the Nigerian Police Force. http://www.hrw.org/sites/default/files/reports/nigeria0810webwcover.pdf. Accessed $6 \mathrm{Au}-$ gust 2014.

HUMAN Rights Watch (2011), Nigeria: Post-Election Violence Killed 800. http://www.hrw.org/news/2011/05/16/nigeria-post-election-violence-killed-800. Accessed 14 August 2014.

HUMAN RighTS WATCH (2014), World Report 2014 - Nigeria. http://www.hrw.org/worldreport/2014/country-chapters/nigeria. Accessed 6 August 2014.

IBEANU, O. \& A. МомоH (2008), State Responsiveness to Public Security Needs. Nigeria Country Case Study. Produced for the project on The Politics of Security Decision-Making. https://www.academia.edu/1944700/State_Responsiveness_to_Public_Security_Needs_The Politics_of_Public_Security_Decision-Making_-_Nigeria_Country_Study. Accessed $7 \overline{\mathrm{Au}}$ gust $20 \overline{14}$.

KATSOURIS, C. \& A. SAYNE (2013), Nigeria's Criminal Crude: International Options to Combat the Export of Stolen Oil. Chatham House.

http://www.chathamhouse.org/sites/files/chathamhouse/public/Research/Africa/0913pr_nige riaoil.pdf. Accessed 6 August 2014.

MaLinA, T. (n.d.), Militancy in the Niger Delta. Mathew B. Ridgway Center for International Security Studies, University of Pittsburgh.

http://www.ridgway.pitt.edu/RidgwayResearch/Issues/InternationalPeaceSecurity/Backgroun dersIPS/tabid/552/smid/1686/ArticleID/646/reftab/497/t/Militancy-in-the-Niger-

Delta/Default.aspx. Accessed 22 May 2014.

MeHLER, A. (2009), The Production of Insecurity by African Security Forces: Insights from Liberia and the Central African Republic. German Institute of Global and Area Studies. http://repec.giga-hamburg.de/pdf/giga_09_wp114_mehler.pdf. Accessed 2 August 2014.

NOPRIN (2007), Criminal Forces? An Interim Report on the Nigeria Police Force. Network on Police Reform in Nigeria (NOPRIN), Lagos.

OJo, O.E. (2010), Boko Haram: Nigeria's Extra-Judicial State. Journal of Sustainable Development in Africa 12(2): 45-62.

PeArce, J., R. MCGeE \& J. WheEler (2011), Violence, Security and Democracy: Perverse Interfaces and Their Implications for States and Citizens in the Global South. IDS Working Paper, No. 357. 
PÉROUSE DE Montclos, M.-A. (2011), Nigeria Watch: Third Report on Violence in Nigeria (2006-2011). http://www.nigeriawatch.org/media/html/NGA-Watch-Report 11(1).pdf. Accessed 11 August 2014.

PÉROUSE DE MONTCLOS, M.-A. (2014), Nigeria Watch: Fourth Report on Violence in Nigeria (2006-2014). http://www.nigeriawatch.org/media/html/NGA-Watch-Report14.pdf. Accessed 24 July 2014.

Persson, H. (2014), Nigeria - An Overview of Challenges to Peace and Security. http://www.foi.se/Documents/Persson, \%20Nigeria\%20$\% 20 \mathrm{An} \% 20$ Overview $\% 20$ of $\% 20$ Challenges $\% 20$ to\%20Peace $\% 20$ and $\% 20$ Security, $\% 202014$. pdf. Accessed 5 August 2014.

SERRANO, R. \& P. ZACHARIAS (2014), By the Numbers: The Nigerian State's Efforts to Counter Boko Haram. In: M.-A. Pérouse de Montclos, ed., Boko Haram: Islamism, Politics, Security and the State in Nigeria, Leiden: African Studies Centre, pp. 192-212.

TERRORISM (Prevention) Act 2011. https://www.unodc.org/tldb/pdf/Nigeria/NIR_Terror_Prevent_2011.pdf. Accessed 4 August 2014.

Uwimana, C. \& L. Wawro (2014), Corruption in Nigeria Military and Security Forces: A Weapon in Boko Haram's Hands. http://saharareporters.com/report/corruption-nigeriasmilitary-and-security-forces-weapon-boko-haram $\% \mathrm{E} 2 \% 80 \% 99$ s-hands-transparency-inter. Accessed 22 June 2014. 


\section{Part II}

Fieldwork and surveys:

A qualitative analysis of violence in Nigeria 
Map 7.1 Invisible violence in some selected LGAs

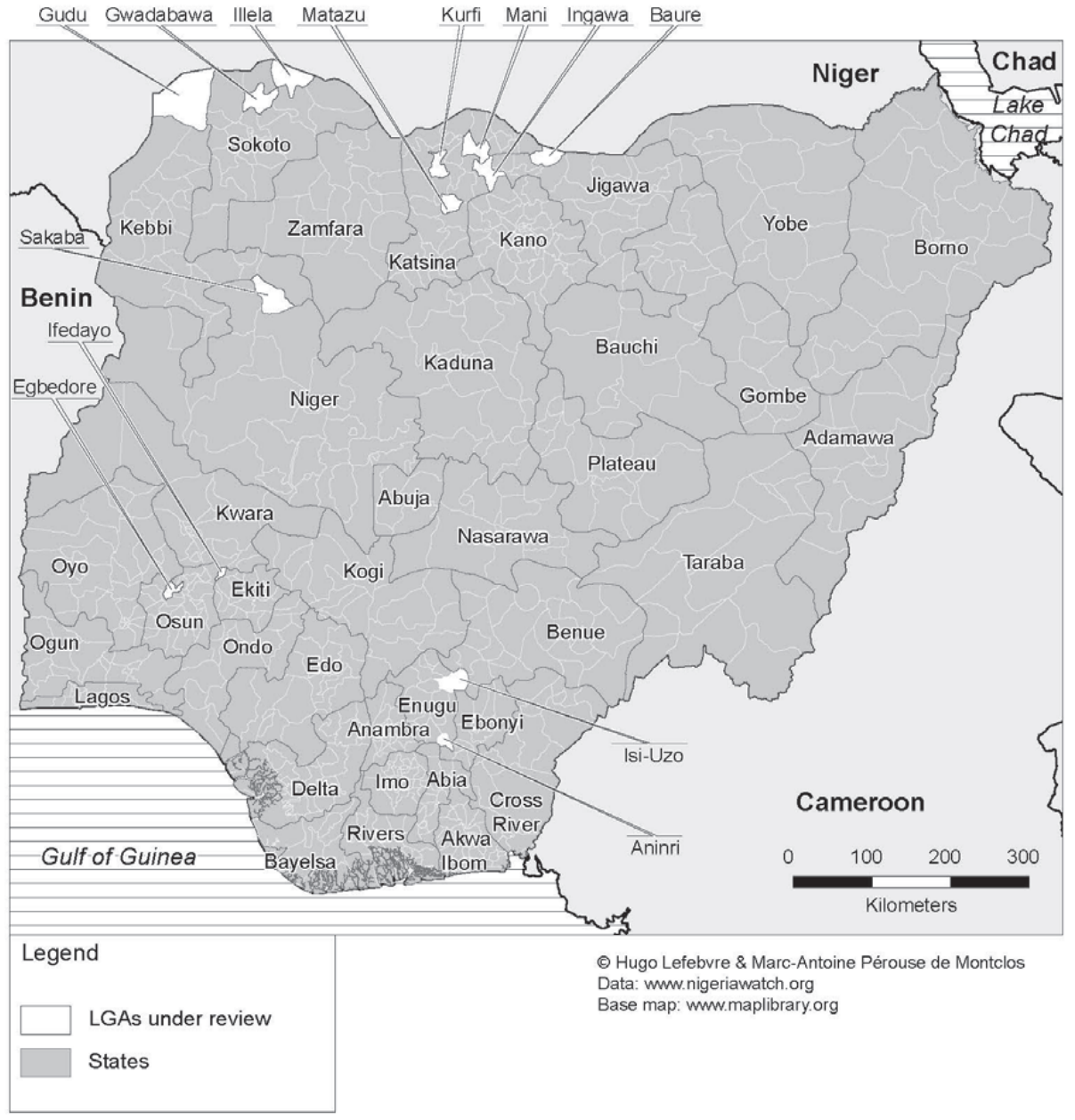




\title{
A survey of violence-related deaths in Aninri and Isi-Uzo LGAs of Enugu State (2006-2014)
}

\author{
Joachin Uche Okanume
}

\begin{abstract}
Aninri and Isi-Uzo are rural LGAs in Enugu West and Enugu East Senatorial Zones of Enugu State, respectively. Their inhabitants are predominantly farmers and traders, who are not immune to violence. Yet many fatal incidents are not reported by the national press. Thus, the general aim of this study is to document virtually all the violence-related deaths that occurred in these two LGAs from June 2006 until May 2014 and to ascertain why they were neglected by the media. Fieldwork was conducted in October 2014 in Aninri and Isi-Uzo LGAs, as well as in Enugu, the state capital. Sixty questionnaires were administered to randomly selected respondents, while 38 key informants were purposively selected and interviewed. The study also utilized two focus group discussions, which were comprised of 17 participants drawn from the various communities that make up the two LGAs. Our findings reveal, among other things, that there have been numerous violent deaths in the study areas within the time frame covered by the study. It was also discovered that the national press neglects these rural LGAs because they have no economic value, lack urban centres, and are difficult to access (particularly Isi-Uzo).
\end{abstract}

\section{Introduction}

In Nigeria, the media report violence-related deaths in virtually all the communities and LGAs of the country. In Enugu State, however, newspapers and magazines have missed many fatal incidents in Aninri and Isi-Uzo LGAs since 2006. Yet these two LGAs did not enjoy peace. Hence this study intends to undertake the following:

1. Document all the violence-related deaths in Aninri and Isi-Uzo from June 2006 to May 2014, the period covered by the Nigeria Watch database.

2. Discover what types of violence occurred.

3. Explain why these LGAs are neglected by the national press. 


\section{Methodology and limitations of the study}

A total of 60 questionnaires, 38 key informant interviews (KIIs), and two focus group discussions (FGDs) were utilized for generating the primary data for the survey. The FGDs were composed of 17 participants drawn from the various communities that make up the two LGAs. The KIIs were conducted with traditional rulers, community leaders, medical doctors, security personnel, journalists, civil servants, women and youth leaders, and commercial motorcyclists. Both the KIIs and FGDs were immensely useful not only in providing detailed information for the study but also in validating some of the data elicited with questionnaires.

A limitation encountered during the survey was the inability of respondents to recall the totality of violence-related deaths that took place in the two LGAs from 2006 to 2014. This might explain why, in Aninri, more incidents were remembered for 2013 than for other years. In Isi-Uzo, however, violence-related deaths peaked in 2010 and 2011 and then declined in 2012, 2013, and 2014 (see Figures 7.1 and 7.2). Clearly, respondents were unable to recall the specific dates of occurrence for most of the incidents remembered. Data had to be cross-checked to confirm that fatal events actually occurred at the places mentioned, despite a few discrepancies with regard to dates. Some law enforcement agents who spoke to the researcher in their individual capacities mentioned specific cases as well as validated some of the information elicited from other sources. However, all efforts by the researcher to gain access to the official records of the security agencies operating within these LGAs yielded no result.

\section{Aninri: Geographical, political and socio-economic profile}

Aninri is an LGA in Enugu West Senatorial Zone of Enugu State. It was created from Awgu LGA in 1996 and its headquarters are at Ndiabor. It has an area of $364 \mathrm{sq} \mathrm{km}$ and a population of 133,723, according to the 2006 census. The LGA has a total of ten wards: one each in Ndiabor, Okpanku, and $\mathrm{Mpu}$; three in Nenwe; and four in Oduma. It is composed of five major communities, which are all Igbo, namely Ndiabor, Mpu, Nenwe, Oduma, and Okpanku. Each of these is further divided into smaller autonomous communities: Ndiabor is split into two autonomous communities; Mpu into four; Nenwe into four; Oduma into eight; and Okpanku into two. There are two police posts, at Mpu and Ekoli-Okpanku, and a police station opposite the LGA Secretariat at Ndiabor. 
Figure 7.1 Percentage of violent deaths per year in Aninri LGA (June 2006-May 2014)

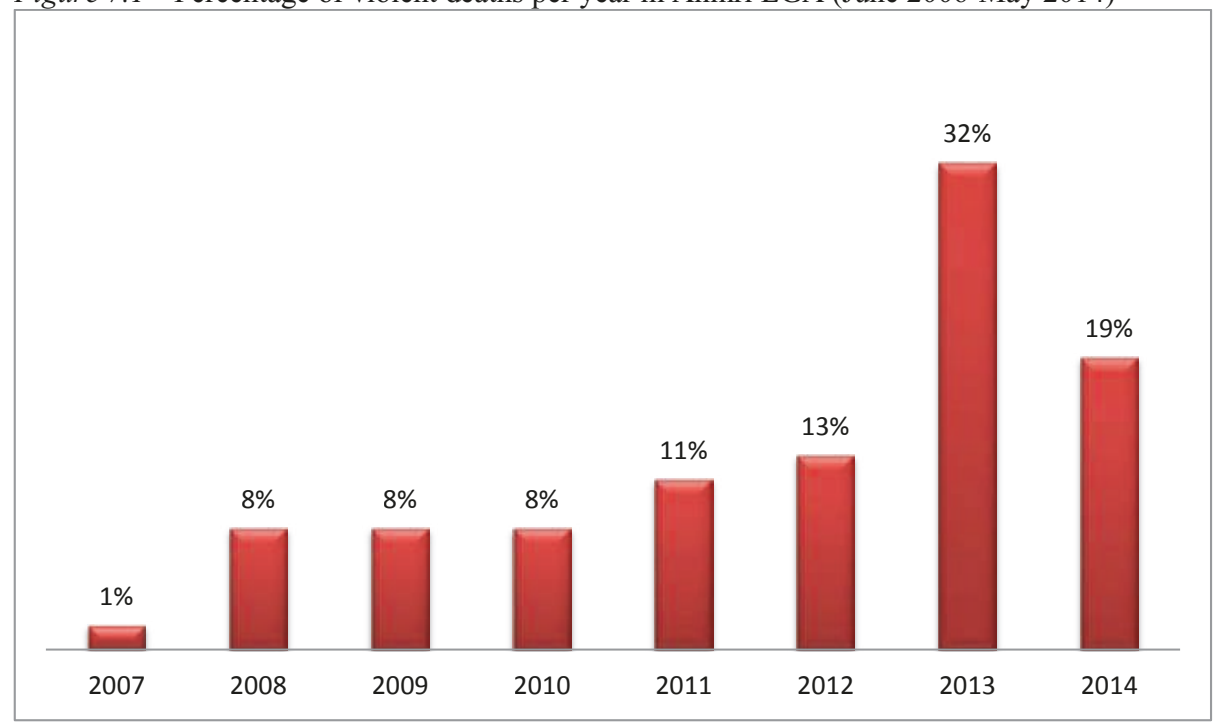

Source: Fieldwork, October 2014

Figure 7.2 Percentage of violent deaths per year in Isi-Uzo LGA (June 2006-May 2014)

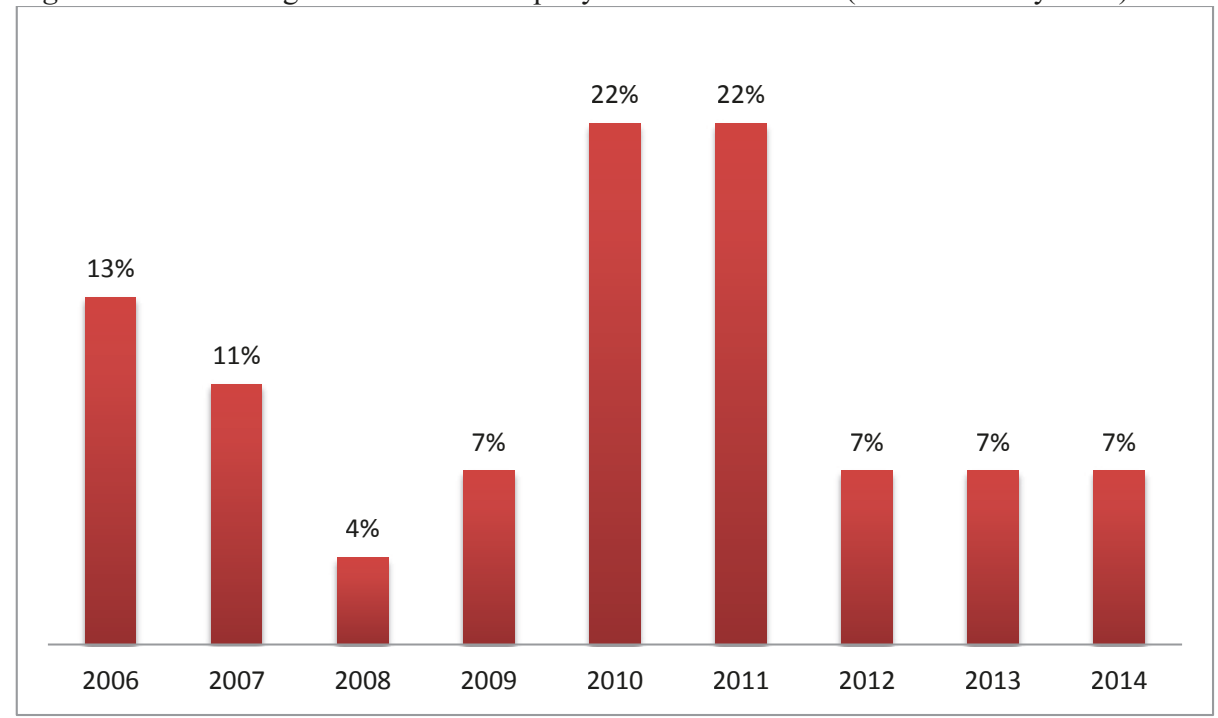

Source: Fieldwork, October 2014

Agriculture is the backbone of the economy because the land is lush, making the people predominantly farmers. The major food products are rice, okro, cassa- 
va, yam, and groundnuts. Being part of a traditional community, people believe that none of them can commit sacrilege, such as killing, without supernatural powers getting the person to confess to the act in his or her lifetime. In their opinion, this system has helped in the curbing of violence, even if the system was brought into serious question when a series of murders were committed by persons who were never identified.

Despite its rural background, Aninri has quite a sizeable number of politicians. Among them are the current Deputy President of Nigeria's Senate, Ike Ekweremadu; the former speaker of the Enugu State House of Assembly, Mr. Abel Chukwu (who is now a member of the Federal Character Commission); and the former state chairman of the People's Democratic Party (PDP), Chief Onyioha Nwanjoku. Aninri has so far had 13 sole administrators and chairmen. Senator Ike Ekweremadu, for instance, became its first executive chairman in 1997 after a sole administrator was appointed when the LGA was created by the military regime of General Sani Abacha in 1996. As in many rural communities in Nigeria, these political heavyweights are not domiciled in the LGA itself. Rather, they reside in Enugu, Abuja, or other large cities; nevertheless, they do contribute to local development. Thus, Aninri had very poor roads before 2011; since then, they have been renovated courtesy of the Federal Government and the Deputy President of the Senate, Senator Ike Ekweremadu.

\section{Isi-Uzo: Geographical, political and socio-economic profile}

Isi-Uzo is an LGA in Enugu East Senatorial Zone of Enugu State. It has an area of $877 \mathrm{sq} \mathrm{km}$ and a population of 148,415, according to the 2006 census. It was initially called Isi-Uzo County Council until it became a District Council in 1950. With its headquarters at Ikem, it is bounded to the east by Ishielu LGA in Ebonyi State, to the west by Enugu East LGA, to the south by Udenu LGA of Enugu State, and to the north by Ogbadibo, Okpokwu, and Ador LGAs in Benue State. The present Isi-Uzo was created in 1976 and includes five main communities, all Igbo: Eha-Amufu, Ikem, Neke, Mbu, and Umualor. In terms of land mass, EhaAmufu is said to constitute about $60 \%$ of the LGA and accommodates seven other autonomous communities. Ikem, Neke, Mbu, and Umualor contain four, four, three, and two autonomous communities, respectively.

As the largest community, Eha-Amufu was formerly said to dominate political affairs in Isi-Uzo. Nowadays, however, political offices rotate among the five main communities, particularly the chairmanship of the LGA. Since its creation in 1976, Isi-Uzo has had 20 chairmen or administrators, none of them being female. The distribution of wards among the major communities is as follows: EhaAmufu has four; Ikem has two; Neke has two; Mbu has two; and Umualor has 
one. The LGA is included in Enugu East Senatorial Zone despite its cultural affinity with the people of Nsukka in Enugu North Senatorial Zone.

Isi-Uzo is a rural area and the majority of the people are farmers and petty traders. The major food products are cassava, rice, yam, and gari. As far back as the 1930s, economic activities started booming when a railway station was built in Eha-Amufu. Today, each of the five major communities of Isi-Uzo has its market day, and the market at Eha-Amufu attracts people from all parts of the country either to sell or to buy items. Eha-Amufu has also benefited from the College of Education which was established there by the old Anambra State in the early 1980s and upgraded to a Federal College of Education ten years later; some of the students and staff still reside in the community. Other infrastructures are to be found at Ikem, which has the only police station in the entire LGA, and Mbu, where the Divisional Office of the Nigeria Security and Civil Defence Corps (NSCDC) is located.

Regarding development, however, almost all the roads in Isi-Uzo are in a deplorable state except the one leading to the headquarters at Ikem from Ugwuogo Nike in Enugu East LGA. This factor, respondents bitterly complained, has adversely affected economic activities in the area. All our respondents at EhaAmufu argued that previously you could see at least ten truckloads of gari leaving the community every market day, as against three nowadays.

\section{Aninri: Discussion of findings}

Table 7.1 shows that there were more male respondents than female. The study was originally designed to administer equal number of questionnaires to both, but the women were not as responsive as the men. The majority of the 30 respondents were married and between the ages of 41 and 50 years. Most of them were self-employed; a few were farmers and civil servants. A majority had lived in Aninri since birth. Hence, most respondents had lived in the LGA for a minimum of eight years, covering the time frame of the study. 
Table 7.1 Demographic characteristics of respondents in Aninri LGA

\begin{tabular}{|c|c|c|}
\hline Sex & $n$ & $\%$ \\
\hline Male & 19 & 63.3 \\
\hline Female & 11 & 36.7 \\
\hline Age & $n$ & $\%$ \\
\hline $20-30$ & 4 & 13.3 \\
\hline $31-40$ & 8 & 26.7 \\
\hline $41-50$ & 13 & 43.3 \\
\hline $51-60$ & 4 & 13.3 \\
\hline Above 60 & 1 & 3.3 \\
\hline Marital status & $n$ & $\%$ \\
\hline Married & 21 & 70.0 \\
\hline Single & 6 & 20.0 \\
\hline Widow/widower & 3 & 10.0 \\
\hline Employment status & $n$ & $\%$ \\
\hline Civil/public servant & 6 & 20.0 \\
\hline Self-employed & 15 & 50.0 \\
\hline Farmer & 7 & 23.3 \\
\hline Student & 2 & 6.7 \\
\hline Years of residence in the community & $n$ & $\%$ \\
\hline $8-10$ years & 7 & 23.3 \\
\hline $11-15$ years & 1 & 3.3 \\
\hline $16-20$ years & 10 & 33.3 \\
\hline Since birth & 12 & 40.0 \\
\hline
\end{tabular}

Source: Fieldwork, October 2014

While $96.7 \%$ of the respondents claimed that their neighbourhood was not violent, all of them were aware of fatal incidents in their various communities. Table 7.2 lists the incidents that readily came to their minds. 
Table 7.2 Violent events recorded in Aninri LGA (June 2006-May 2014)

\begin{tabular}{|c|c|c|c|c|c|}
\hline $\mathrm{S} / \mathrm{n}$ & Date & Community & Cause & Description & $\begin{array}{l}\text { No. of } \\
\text { deaths }\end{array}$ \\
\hline 1 & 2007 & Amachara & Accident & $\begin{array}{l}\text { A man went fishing and } \\
\text { drowned in the river. }\end{array}$ & 1 \\
\hline 2 & 2008 & Amaorji Nenwe & Crime & $\begin{array}{l}\text { A boy was said to have } \\
\text { murdered his uncle with a } \\
\text { machete. }\end{array}$ & 1 \\
\hline 3 & 2008 & $\begin{array}{l}\text { Obiofu Amaorji } \\
\text { Nenwe }\end{array}$ & Accident & $\begin{array}{l}\text { A palm tree cutter fell and } \\
\text { died. }\end{array}$ & 1 \\
\hline 4 & 2008 & $\begin{array}{l}\text { Obiofu Amaorji } \\
\text { Nenwe }\end{array}$ & Accident & $\begin{array}{l}\text { Another palm tree cutter fell } \\
\text { and died. The deceased's } \\
\text { wife and son later died in a } \\
\text { motor accident in a different } \\
\text { LGA. }\end{array}$ & 1 \\
\hline 5 & $\begin{array}{l}30 \mathrm{Dec} \\
2008\end{array}$ & $\begin{array}{l}\text { Nenwe Junction, } \\
\text { along Port Har- } \\
\text { court-Enugu } \\
\text { Expressway } \\
\end{array}$ & $\begin{array}{l}\text { Motor } \\
\text { accident }\end{array}$ & $\begin{array}{l}\text { A teenage girl went to fetch } \\
\text { some water and was hit by a } \\
\text { vehicle. }\end{array}$ & 1 \\
\hline 6 & 2008 & $\begin{array}{l}\text { Nenwe Junction, } \\
\text { along Port Har- } \\
\text { court-Enugu } \\
\text { Expressway }\end{array}$ & $\begin{array}{l}\text { Motor } \\
\text { accident }\end{array}$ & $\begin{array}{l}\text { A former security man at } \\
\text { Comprehensive Secondary } \\
\text { School, Nenwe was hit by a } \\
\text { vehicle as he was riding his } \\
\text { bicycle to night duty. }\end{array}$ & 1 \\
\hline 7 & 2009 & $\begin{array}{l}\text { Obuagu Mpu, } \\
\text { along Ishiagu } \\
\text { road } \\
\end{array}$ & $\begin{array}{l}\text { Motorcycle } \\
\text { accident }\end{array}$ & $\begin{array}{l}\text { A commercial motorcyclist } \\
\text { hit and killed a man cross- } \\
\text { ing the road. }\end{array}$ & 1 \\
\hline 8 & 2009 & $\begin{array}{l}\text { Abacheku vil- } \\
\text { lage, Ndiabor }\end{array}$ & $\begin{array}{l}\text { Land dis- } \\
\text { pute }\end{array}$ & $\begin{array}{l}\text { A woman was reportedly } \\
\text { killed as she was farming } \\
\text { on disputed land between } \\
\text { Ndiabor and Oduma. }\end{array}$ & 1 \\
\hline 9 & 2009 & Oduma & Crime & $\begin{array}{l}\text { A mother came to separate } \\
\text { two male siblings fighting; } \\
\text { in the process, one of the } \\
\text { boys cut her with a machete } \\
\text { and she died. }\end{array}$ & 1 \\
\hline 10 & 2009 & $\begin{array}{l}\text { Obiofu Junction, } \\
\text { Amaorji Nenwe }\end{array}$ & $\begin{array}{c}\text { Motor } \\
\text { accident }\end{array}$ & A woman was hit by a car. & 1 \\
\hline 11 & 2009 & Nenwe & $\begin{array}{l}\text { Motor } \\
\text { accident }\end{array}$ & $\begin{array}{l}\text { A cyclist was hit in an acci- } \\
\text { dent involving a car and a } \\
\text { commercial motorcycle; he } \\
\text { later died in hospital. }\end{array}$ & 1 \\
\hline 12 & $\begin{array}{l}31 \text { Aug } \\
2010\end{array}$ & Nenwe & $\begin{array}{l}\text { Motorcycle } \\
\text { accident }\end{array}$ & $\begin{array}{l}\text { Two motorcycles had a } \\
\text { head-on collision and one } \\
\text { rider died. }\end{array}$ & 1 \\
\hline 13 & Oct 2010 & $\begin{array}{l}\text { Nenwe, along } \\
\text { Nenwe/Mgbowo } \\
\text { road }\end{array}$ & $\begin{array}{l}\text { Motorcycle } \\
\text { accident }\end{array}$ & $\begin{array}{l}\text { An over-speeding private } \\
\text { motorcyclist had an acci- } \\
\text { dent at an ongoing bridge } \\
\text { construction site. }\end{array}$ & 1 \\
\hline 14 & 2010 & $\begin{array}{l}\text { Obiofu Junction, } \\
\text { Amaorji Nenwe }\end{array}$ & $\begin{array}{c}\text { Motor } \\
\text { accident }\end{array}$ & $\begin{array}{l}\text { A woman was hit by a car } \\
\text { on her way from a farm. }\end{array}$ & 1 \\
\hline
\end{tabular}


Table 7.2 Violent events recorded in Aninri LGA (June 2006-May 2014) continued

\begin{tabular}{|c|c|c|c|c|c|}
\hline 15 & 2010 & $\begin{array}{l}\text { Amangwu vil- } \\
\text { lage, Ndiabor }\end{array}$ & Accident & $\begin{array}{l}\text { A young boy drowned in a } \\
\text { pond. }\end{array}$ & 1 \\
\hline 16 & 2010 & Aguenyi Mpu & Crime & $\begin{array}{l}\text { A female farmer was mur- } \\
\text { dered by herdsmen whom } \\
\text { she had scolded for tres- } \\
\text { passing onto her farm with } \\
\text { their cattle. }\end{array}$ & 1 \\
\hline 17 & 2011 & Uke Mpu & Crime & $\begin{array}{l}\text { A woman was allegedly } \\
\text { murdered on her farm by } \\
\text { herdsmen while she was } \\
\text { cutting bamboo sticks. }\end{array}$ & 1 \\
\hline 18 & 2011 & $\begin{array}{l}\text { Umuoma vil- } \\
\text { lage, Ndiabor }\end{array}$ & Crime & $\begin{array}{l}\text { A woman allegedly hit and } \\
\text { killed her husband with a } \\
\text { digger. }\end{array}$ & 1 \\
\hline 19 & 2011 & Amaeke Oduma & $\begin{array}{l}\text { Motorcycle } \\
\text { accident }\end{array}$ & $\begin{array}{l}\text { A man lost his life in an } \\
\text { accident involving two } \\
\text { motorcycles in a head-on } \\
\text { collision. }\end{array}$ & 1 \\
\hline 20 & 2011 & Ohafia Oduma & Crime & $\begin{array}{l}\text { At a building construction } \\
\text { site, a young boy clubbed } \\
\text { another to death with a } \\
\text { stick. }\end{array}$ & 1 \\
\hline 21 & 2011 & $\begin{array}{l}\text { Nenwe, along } \\
\text { Mgbowo road }\end{array}$ & $\begin{array}{l}\text { Motor } \\
\text { accident }\end{array}$ & $\begin{array}{l}\text { A cyclist died instantly in } \\
\text { an accident involving a } \\
\text { tipper and a motorcyclist. }\end{array}$ & 1 \\
\hline 22 & 2011 & $\begin{array}{l}\text { Nenwe, along } \\
\text { Oduma road }\end{array}$ & $\begin{array}{l}\text { Motor } \\
\text { accident }\end{array}$ & $\begin{array}{l}\text { A woman hit by a car died } \\
\text { later at the University of } \\
\text { Nigeria Teaching Hospital. }\end{array}$ & 1 \\
\hline 23 & 2011 & Ndiabor & Crime & $\begin{array}{l}\text { A man was allegedly mur- } \\
\text { dered and dumped in a bush } \\
\text { behind the LGA Secretariat. }\end{array}$ & 1 \\
\hline 24 & Feb 2012 & Okpanku & $\begin{array}{l}\text { Motor } \\
\text { accident }\end{array}$ & $\begin{array}{l}\text { A car and a commercial } \\
\text { motorcyclist had a head-on } \\
\text { collision. The cyclist and } \\
\text { his passenger died instantly. }\end{array}$ & 2 \\
\hline 25 & 2012 & Amaorji Nenwe & Crime & $\begin{array}{l}\text { A man was murdered and } \\
\text { dumped in the bush. }\end{array}$ & 1 \\
\hline 26 & Sept 2012 & Amaorji Nenwe & Crime & $\begin{array}{l}\text { A girl's naked and lifeless } \\
\text { body was found somewhere } \\
\text { near St. Peter's Catholic } \\
\text { Church. The autopsy re- } \\
\text { vealed that she was raped to } \\
\text { death. }\end{array}$ & 1 \\
\hline 27 & 2012 & Agbada Nenwe & Accident & $\begin{array}{l}\text { A carpenter fell from a } \\
\text { building where he was } \\
\text { working. }\end{array}$ & 1 \\
\hline
\end{tabular}


Table 7.2 Violent events recorded in Aninri LGA (June 2006-May 2014) continued

\begin{tabular}{|c|c|c|c|c|c|}
\hline 28 & 2012 & $\begin{array}{c}\text { Nenwe Junc- } \\
\text { tion, along Port } \\
\text { Harcourt-Enugu } \\
\text { Expressway } \\
\end{array}$ & $\begin{array}{l}\text { Motorcycle } \\
\text { accident }\end{array}$ & $\begin{array}{l}\text { A man was hit by a motor- } \\
\text { cycle and died. }\end{array}$ & 1 \\
\hline 29 & 2012 & $\begin{array}{l}\text { Nenwe Junc- } \\
\text { tion, along Port } \\
\text { Harcourt-Enugu } \\
\text { Expressway } \\
\end{array}$ & $\begin{array}{l}\text { Motorcycle } \\
\text { accident }\end{array}$ & $\begin{array}{l}\text { A man was hit by a motor- } \\
\text { cycle and later died in hos- } \\
\text { pital. }\end{array}$ & 1 \\
\hline 30 & 2012 & $\begin{array}{l}\text { Ugwungo vil- } \\
\text { lage, Ndiabor }\end{array}$ & Crime & $\begin{array}{l}\text { One boy died while fighting } \\
\text { with another one. }\end{array}$ & 1 \\
\hline 31 & 2012 & Obuagu Mpu & $\begin{array}{l}\text { Motor } \\
\text { accident }\end{array}$ & $\begin{array}{l}\text { An accident between a bus } \\
\text { and a commercial motorcy- } \\
\text { cle killed two. }\end{array}$ & 2 \\
\hline 32 & $\begin{array}{l}25 \mathrm{Dec} \\
2012\end{array}$ & Aguenyi Mpu & Accident & $\begin{array}{l}\text { A man was electrocuted at } \\
\text { an electric transformer. }\end{array}$ & 1 \\
\hline 33 & Jan 2013 & Okpanku & $\begin{array}{c}\text { Motor } \\
\text { accident }\end{array}$ & $\begin{array}{l}\text { A commercial motorcyclist } \\
\text { died when he hit a car. }\end{array}$ & 1 \\
\hline 34 & 2013 & Amagu Mpu & Crime & $\begin{array}{l}\text { A man was allegedly mur- } \\
\text { dered. }\end{array}$ & 1 \\
\hline 35 & 2013 & Amagu Mpu & Crime & $\begin{array}{l}\text { A man was allegedly shot } \\
\text { dead by armed robbers. }\end{array}$ & 1 \\
\hline 36 & 2013 & Ovum Mpu & Crime & $\begin{array}{l}\text { A young girl's dead body } \\
\text { was found near the river. } \\
\text { An autopsy allegedly re- } \\
\text { vealed she had been raped } \\
\text { to death. }\end{array}$ & 1 \\
\hline 37 & 2013 & $\begin{array}{l}\text { Mpu, along } \\
\text { Ishiagu road }\end{array}$ & $\begin{array}{c}\text { Motor } \\
\text { accident }\end{array}$ & $\begin{array}{l}\text { A bus hit an eight-year old } \\
\text { girl. }\end{array}$ & 1 \\
\hline 38 & 2013 & $\begin{array}{l}\text { Mpu, along } \\
\text { Oduma road }\end{array}$ & $\begin{array}{c}\text { Motor } \\
\text { accident }\end{array}$ & $\begin{array}{l}\text { A bus killed a girl. The } \\
\text { driver reportedly ran away. }\end{array}$ & 1 \\
\hline 39 & 2013 & Obuagu & Accident & $\begin{array}{l}\text { A young prince of the } \\
\text { community was drowned in } \\
\text { a river. }\end{array}$ & 1 \\
\hline 40 & 2013 & $\begin{array}{l}\text { Umarah village, } \\
\text { Ndiabor }\end{array}$ & $\begin{array}{l}\text { Land dis- } \\
\text { pute }\end{array}$ & $\begin{array}{l}\text { A young man used a short } \\
\text { bamboo stick and beat his } \\
\text { uncle to death. He reported- } \\
\text { ly did not run away but } \\
\text { waited until the police came } \\
\text { and apprehended him. }\end{array}$ & 1 \\
\hline 41 & 2013 & $\begin{array}{l}\text { Amaururo vil- } \\
\text { lage, Ndiabor }\end{array}$ & Crime & $\begin{array}{l}\text { A madman attacked and } \\
\text { killed a woman. }\end{array}$ & 1 \\
\hline 42 & 2013 & Emudo Nenwe & Sorcery & $\begin{array}{l}\text { A man was caught after he } \\
\text { had allegedly killed a four- } \\
\text { year old child, purportedly } \\
\text { for ritual purposes. }\end{array}$ & 1 \\
\hline
\end{tabular}


Table 7.2 Violent events recorded in Aninri LGA (June 2006-May 2014) continued

\begin{tabular}{|c|c|c|c|c|c|}
\hline 43 & 2013 & $\begin{array}{l}\text { Ndiabor, along } \\
\text { Mpu road }\end{array}$ & $\begin{array}{l}\text { Motor } \\
\text { accident }\end{array}$ & $\begin{array}{l}\text { A man riding on a motorcy- } \\
\text { cle with his wife hit a car; } \\
\text { the woman died on the spot. }\end{array}$ & 1 \\
\hline 44 & May 2013 & $\mathrm{Mpu}$ & $\begin{array}{l}\text { Motorcycle } \\
\text { accident }\end{array}$ & $\begin{array}{l}\text { A motorcyclist hit a wall } \\
\text { and died instantly. }\end{array}$ & 1 \\
\hline 45 & June 2013 & $\begin{array}{l}\text { Amaogudu vil- } \\
\text { lage, Okpanku }\end{array}$ & $\begin{array}{l}\text { Motor } \\
\text { accident }\end{array}$ & $\begin{array}{l}\text { A Hausa passenger on a } \\
\text { commercial motorcycle was } \\
\text { severely injured in an acci- } \\
\text { dent with a Volvo car; he } \\
\text { died in hospital the same } \\
\text { day. }\end{array}$ & 1 \\
\hline 46 & July 2013 & Oduma & Crime & $\begin{array}{l}\text { A commercial bus driver } \\
\text { was strangled to death by } \\
\text { unknown persons. }\end{array}$ & 1 \\
\hline 47 & 2013 & $\begin{array}{l}\text { Obiofu Junc- } \\
\text { tion, Amaorji } \\
\text { Nenwe }\end{array}$ & $\begin{array}{l}\text { Motorcycle } \\
\text { accident }\end{array}$ & $\begin{array}{l}\text { An elderly woman was hit } \\
\text { by a truck while she was } \\
\text { crossing the expressway on } \\
\text { her way from her farm. }\end{array}$ & 1 \\
\hline 48 & 2013 & Nenwe & Crime & $\begin{array}{l}\text { A man's lifeless body was } \\
\text { found in a bush not far from } \\
\text { his motorcycle. The de- } \\
\text { ceased allegedly chased } \\
\text { people's wives and was } \\
\text { therefore suspected to have } \\
\text { been killed for revenge. }\end{array}$ & 1 \\
\hline 49 & Nov 2013 & $\begin{array}{l}\text { Nenwe, along } \\
\text { Mgbowo road }\end{array}$ & $\begin{array}{c}\text { Motor } \\
\text { accident }\end{array}$ & $\begin{array}{l}\text { A cyclist ran into a bus and } \\
\text { died instantly. }\end{array}$ & 1 \\
\hline 50 & Nov 2013 & Oduma & Crime & $\begin{array}{l}\text { A man was said to have } \\
\text { been stabbed to death by } \\
\text { unknown persons. }\end{array}$ & 1 \\
\hline 51 & Dec 2013 & Nenwe & Crime & $\begin{array}{l}\text { A young man was found } \\
\text { dead with injuries on his } \\
\text { body at the boundary be- } \\
\text { tween Nenwe and Omogho. }\end{array}$ & 1 \\
\hline 52 & $\begin{array}{l}25 \mathrm{Dec} \\
2013\end{array}$ & $\begin{array}{l}\text { Aguenyi Mpu, } \\
\text { opposite the } \\
\text { secondary } \\
\text { school }\end{array}$ & $\begin{array}{l}\text { Motor } \\
\text { accident }\end{array}$ & $\begin{array}{l}\text { A commercial motorcyclist } \\
\text { died instantly in an accident } \\
\text { with a car. }\end{array}$ & 1 \\
\hline 53 & Jan 2014 & Ohafia Oduma & Crime & $\begin{array}{l}\text { A boy used a stick and beat } \\
\text { another boy to death. }\end{array}$ & 1 \\
\hline 54 & Jan 2014 & $\begin{array}{l}\text { Ohafia Oduma, } \\
\text { close to Afor } \\
\text { market }\end{array}$ & $\begin{array}{l}\text { Motorcycle } \\
\text { accident }\end{array}$ & $\begin{array}{l}\text { Two motorcycles had a } \\
\text { head-on collision. }\end{array}$ & 1 \\
\hline 55 & $\begin{array}{c}\text { 26 Jan } \\
2014 \\
\end{array}$ & Uhueze Nenwe & Accident & $\begin{array}{l}\text { A man was electrocuted on } \\
\text { an electric pole. }\end{array}$ & 1 \\
\hline 56 & Feb 2014 & Ohafia Oduma & $\begin{array}{c}\text { Motorcycle } \\
\text { accident }\end{array}$ & $\begin{array}{l}\text { A man had a head-on colli- } \\
\text { sion on his motorcycle. }\end{array}$ & 1 \\
\hline
\end{tabular}


Table 7.2 Violent events recorded in Aninri LGA (June 2006-May 2014) continued

\begin{tabular}{|c|c|c|c|l|c|}
\hline 57 & Mar 2014 & $\begin{array}{c}\text { Nenwe Junc- } \\
\text { tion, along Port } \\
\text { Harcourt-Enugu } \\
\text { Expressway }\end{array}$ & $\begin{array}{c}\text { Motor } \\
\text { accident }\end{array}$ & $\begin{array}{l}\text { Two persons died on the } \\
\text { spot in a car accident. }\end{array}$ & 2 \\
\hline 58 & 2014 & Emudo Nenwe & Accident & $\begin{array}{l}\text { A man fell from a tree and } \\
\text { died as he was being taken } \\
\text { to a hospital. }\end{array}$ & 1 \\
\hline 60 & 2014 & $\begin{array}{c}\text { Aninri LGA } \\
\text { Secretariat, } \\
\text { Ndiabor }\end{array}$ & Accident & $\begin{array}{l}\text { A man reportedly fell from } \\
\text { a tree while cutting palm } \\
\text { fruit within the premises of } \\
\text { the LGA Secretariat. }\end{array}$ & 1 \\
\hline 61 & May 2014 & $\begin{array}{c}\text { Aguenyi Mpu } \\
\text { Nenwe Girls } \\
\text { High School }\end{array}$ & $\begin{array}{c}\text { Motorcycle } \\
\text { accident }\end{array}$ & $\begin{array}{l}\text { A pregnant woman was } \\
\text { riding on a private motor- } \\
\text { cycle when she was hit by a } \\
\text { car. She died on the spot. }\end{array}$ & $\begin{array}{l}\text { A commercial motorcyclist } \\
\text { had a road accident. }\end{array}$ \\
\hline 62 & May 2014 & Ohafia Oduma & $\begin{array}{c}\text { Motor } \\
\text { accident }\end{array}$ & $\begin{array}{l}\text { A young child was hit by a } \\
\text { truck belonging to Setraco, } \\
\text { a construction company } \\
\text { working on the road. }\end{array}$ & 1 \\
\hline 63 & May 2014 & Oduma & $\begin{array}{c}\text { Motor } \\
\text { accident }\end{array}$ & $\begin{array}{l}\text { A man was hit by a tipper } \\
\text { belonging to Setraco. }\end{array}$ & 1 \\
\hline
\end{tabular}

Source: Fieldwork, October 2014

Table 7.2 reveals that at least 66 violence-related deaths occurred in Aninri LGA from June 2006 to May 2014: 44 from accidents, 19 from crimes, two from land disputes, and one from sorcery. Motor accidents involving cars, buses, lorries, trucks, and motorcycles were by far the most deadly (Figure 7.3). Data on Aninri clearly show a rise in the number of fatalities within the period covered by the study, and this may be connected to the fact that the recall period was shorter and people remembered better. Interestingly enough, respondents lamented the fact that the good roads provided by the government had become a source of concern owing to over-speeding and reckless driving. The study revealed that 26 people had lost their lives in motor and motorcycle accidents in the last three years, as against eight persons who had died from the same cause prior to the time the roads were extended to most parts of the LGA. This calls for a vigorous public enlightenment campaign, targeting more particularly commercial motorcyclists and bus drivers. 
Figure 7.3 Percentage of causes of violent deaths in Aninri LGA (June 2006-May 2014)

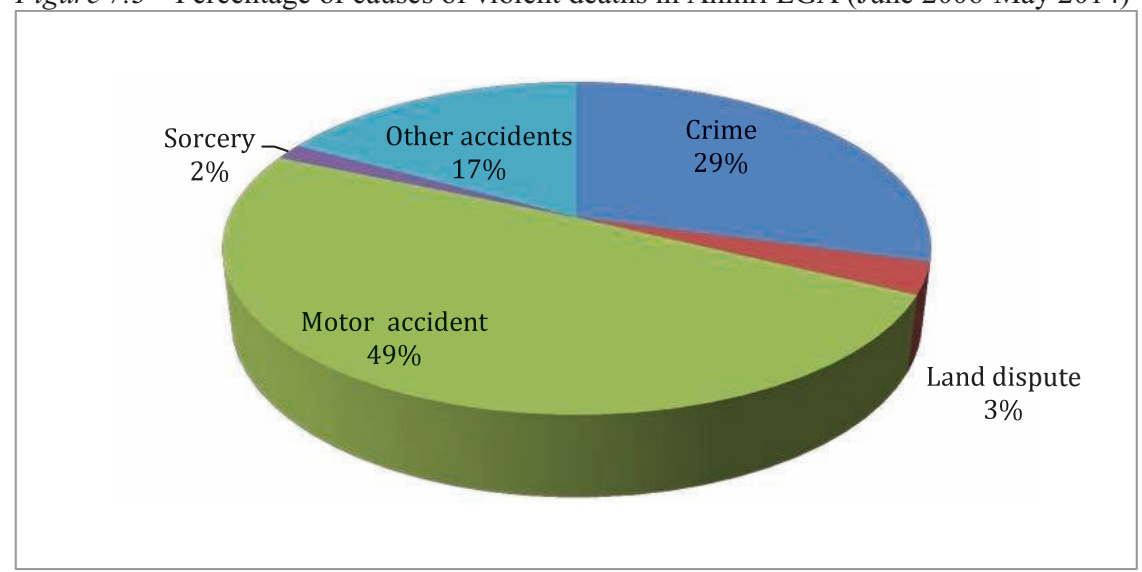

Source: Fieldwork, October 2014

According to the survey, $90 \%$ of the respondents confirmed that the national press grossly under-reported violence in Aninri, while 10\% stated that they did not know. In the case of the Ezza people who were said to have migrated from Ebonyi State to Ndiabor and Mpu, for instance, occasional skirmishes over land between the settlers and the indigenes were not covered by the media. The reasons advanced for this neglect were the lack of urban centres, the distant location from the state capital, and the absence of economic benefits for the media. Interestingly enough, none of the respondents mentioned lack of access roads as a factor in under-reporting the area, unlike the respondents in Isi-Uzo (as we shall see below). Indeed, Aninri communities now have very good access roads, except the ones from Nenwe to Oduma, and from Mpu to Oduma, which was under construction at the time of fieldwork.

\section{Isi-Uzo: Discussion of findings}

Table 7.3 shows that the majority of respondents in Isi-Uzo LGA were male. As in the case of Aninri, females were more reluctant to respond to the questionnaires. The majority of the respondents were married and in the age bracket of 31-50 years. More than half were born in Isi-Uzo LGA, and most had lived in the area long enough to be conversant with violence-occasioned deaths within the stipulated period (2006-2014). 
Table 7.3 Demographic characteristics of respondents in Isi-Uzo LGA

\begin{tabular}{|c|c|c|}
\hline $\operatorname{Sex}$ & $n$ & $\%$ \\
\hline Male & 21 & 70.0 \\
\hline Female & 9 & 30.0 \\
\hline Age & $n$ & $\%$ \\
\hline $20-30$ & 4 & 13.3 \\
\hline $31-40$ & 10 & 33.3 \\
\hline $41-50$ & 10 & 33.3 \\
\hline $51-60$ & 3 & 10.0 \\
\hline Above 60 & 3 & 10.0 \\
\hline Marital status & $n$ & $\%$ \\
\hline Married & 20 & 66.7 \\
\hline Single & 8 & 26.7 \\
\hline Widow/widower & 2 & 6.7 \\
\hline \multicolumn{3}{|l|}{ Employment status } \\
\hline & $n$ & $\%$ \\
\hline Civil/public servant & 6 & 20.0 \\
\hline Self-employed & 17 & 56.7 \\
\hline Farmer & 4 & 13.3 \\
\hline Student & 2 & 6.7 \\
\hline Retired & $\begin{array}{l}2 \\
1\end{array}$ & $\begin{array}{l}0.1 \\
3.3\end{array}$ \\
\hline Years of residence in the community & $n$ & $\%$ \\
\hline $8-10$ years & 2 & 6.7 \\
\hline $11-15$ years & 4 & 13.3 \\
\hline $16-20$ years & 7 & 23.3 \\
\hline Since birth & 17 & 56.7 \\
\hline
\end{tabular}

Source: Fieldwork, October 2014

While $86.7 \%$ of the respondents claimed that their neighbourhood was not violent, all of them were aware of fatal incidents in their locality. Table 7.4 lists the violent incidents that respondents recalled. 
Table 7.4 Violent events recorded in Isi-Uzo LGA (June 2006-May 2014)

\begin{tabular}{|c|c|c|c|c|c|}
\hline $\mathrm{S} / \mathrm{n}$ & Date & Community & Cause & Description & No. of deaths \\
\hline 1 & 2006 & $\begin{array}{c}\text { Amede \& Umuhu } \\
\text { in Eha-Amufu }\end{array}$ & Religious issue & $\begin{array}{l}\text { A group of Christian } \\
\text { youths organized 'a cru- } \\
\text { sade' and went on the } \\
\text { rampage on what they } \\
\text { called a war against idol } \\
\text { worshippers. }\end{array}$ & 3 \\
\hline 2 & 2006 & Eha-Amufu & Crime & $\begin{array}{l}\text { The community's vigi- } \\
\text { lante group went to ar- } \\
\text { rest a suspected notori- } \\
\text { ous criminal and killed } \\
\text { him. }\end{array}$ & 1 \\
\hline 3 & Jan 2007 & $\begin{array}{c}\text { Umuhu in Eha- } \\
\text { Amufu }\end{array}$ & Crime & $\begin{array}{l}\text { A man was said to have } \\
\text { been caught dancing } \\
\text { around the grave of } \\
\text { somebody buried the } \\
\text { previous day, and he was } \\
\text { lynched by a mob. }\end{array}$ & 1 \\
\hline 4 & 2007 & Mbu & Land dispute & $\begin{array}{l}\text { Two young men alleged- } \\
\text { ly set on fire a thatched } \\
\text { house erected by their } \\
\text { cousin on a disputed } \\
\text { piece of land. The owner } \\
\text { of the house shot dead } \\
\text { the two cousins with a } \\
\text { Dane gun in a barber's } \\
\text { shop and ran away. }\end{array}$ & 2 \\
\hline 5 & 2008 & Mbu & Crime & $\begin{array}{l}\text { Two young men had a } \\
\text { quarrel. One of them } \\
\text { went home, got a knife, } \\
\text { and stabbed the other to } \\
\text { death. }\end{array}$ & 1 \\
\hline 6 & 2009 & $\mathrm{Mbu}$ & Sorcery & $\begin{array}{l}\text { A woman believed to be } \\
\text { under demoniac influ- } \\
\text { ence was taken to a } \\
\text { church to be attended to } \\
\text { by 'prayer warriors'. A } \\
\text { church member applied } \\
\text { force to calm her down } \\
\text { and killed her. }\end{array}$ & 1 \\
\hline 7 & 2009 & $\begin{array}{c}\text { Amede, Eha- } \\
\text { Amufu }\end{array}$ & Crime & $\begin{array}{l}\text { A boy stabbed his friend } \\
\text { to death because of N50 } \\
\text { after they had both hired } \\
\text { a wheelbarrow and } \\
\text { worked on a construction } \\
\text { site. }\end{array}$ & 1 \\
\hline
\end{tabular}


Table 7.4 Violent events recorded in Isi-Uzo LGA (June 2006-May 2014), continued

\begin{tabular}{|c|c|c|c|c|c|}
\hline 8 & 2010 & $\begin{array}{l}\text { Federal College } \\
\text { of Education, } \\
\text { Eha-Amufu }\end{array}$ & Sorcery & $\begin{array}{l}\text { A female student of the } \\
\text { institution was axed to } \\
\text { death by suspected cult- } \\
\text { ists. }\end{array}$ & 1 \\
\hline 9 & 2010 & $\begin{array}{l}\text { Ihenyi, Eha- } \\
\text { Amufu }\end{array}$ & Crime & $\begin{array}{l}\text { A boy stabbed his girl- } \\
\text { friend to death. }\end{array}$ & 1 \\
\hline 10 & 2010 & $\begin{array}{c}\text { Ngelekwe, Eha- } \\
\text { Amufu }\end{array}$ & Crime & $\begin{array}{l}\text { A girl was strangled to } \\
\text { death. }\end{array}$ & 1 \\
\hline 11 & 2010 & $\begin{array}{l}\text { Agu Amede, } \\
\text { Eha-Amufu }\end{array}$ & Crime & $\begin{array}{l}\text { A boy attacked and } \\
\text { killed a girl after they } \\
\text { had a quarrel. }\end{array}$ & 1 \\
\hline 12 & 2010 & $\begin{array}{c}\text { Ikem, along } \\
\text { Ikem-Neke road }\end{array}$ & $\begin{array}{c}\text { Motorcycle acci- } \\
\text { dent }\end{array}$ & $\begin{array}{l}\text { Two motorcycles had a } \\
\text { head-on collision. }\end{array}$ & 1 \\
\hline 13 & 2010 & $\mathrm{Mbu}$ & Crime & $\begin{array}{l}\text { A young man beat an old } \\
\text { man who tried to stop a } \\
\text { fight; the old man re- } \\
\text { portedly died on his way } \\
\text { to hospital. }\end{array}$ & 1 \\
\hline 14 & 2011 & $\begin{array}{l}\text { Umuhu, Eha- } \\
\text { Amufu }\end{array}$ & Crime & $\begin{array}{l}\text { Two women dating the } \\
\text { same man were fighting } \\
\text { over who would eventu- } \\
\text { ally become his wife; } \\
\text { one of them stabbed the } \\
\text { other to death. }\end{array}$ & 1 \\
\hline 15 & $\begin{array}{l}\text { 4 May } \\
2011\end{array}$ & Eha-Amufu & Crime & $\begin{array}{l}\text { There was a bank rob- } \\
\text { bery at a branch of First } \\
\text { Bank PLC. }\end{array}$ & 4 \\
\hline 16 & 2011 & Ogor, Ikem & Crime & $\begin{array}{l}\text { A unmarried young man } \\
\text { was cohabiting with a } \\
\text { woman whose mother } \\
\text { insisted that her daughter } \\
\text { must return home. The } \\
\text { infuriated man went to } \\
\text { the would-be mother-in- } \\
\text { law's residence, behead- } \\
\text { ed her, and ran away. }\end{array}$ & 1 \\
\hline 17 & $\begin{array}{l}25 \mathrm{Dec} \\
2012\end{array}$ & $\begin{array}{l}\text { Agu Amede, } \\
\text { Eha-Amufu }\end{array}$ & Crime & $\begin{array}{l}\text { A young boy attacked an } \\
\text { old woman because she } \\
\text { had scolded him over } \\
\text { forcing a young girl to } \\
\text { be in a relationship with } \\
\text { him. }\end{array}$ & 1 \\
\hline 18 & 2012 & Neke & Motor accident & $\begin{array}{l}\text { During the construction } \\
\text { of Ugwuogo Nike-Neke } \\
\text { road, a truck belonging } \\
\text { to the construction firm } \\
\text { killed a cyclist. }\end{array}$ & 1 \\
\hline
\end{tabular}


Table 7.4 Violent events recorded in Isi-Uzo LGA (June 2006-May 2014), continued

\begin{tabular}{|c|c|c|c|c|c|}
\hline 19 & $\begin{array}{c}25 \mathrm{Dec} \\
2013\end{array}$ & Ikem & Land dispute & $\begin{array}{l}\text { In a heated argument } \\
\text { between two families } \\
\text { over a land boundary, } \\
\text { one of them, who was } \\
\text { said to be a soldier, } \\
\text { stabbed another to death. }\end{array}$ & 1 \\
\hline 20 & 2013 & Eha-Amufu & Crime & $\begin{array}{l}\text { A woman who was be- } \\
\text { lieved to be mad gave } \\
\text { birth to a daughter and } \\
\text { killed her. }\end{array}$ & 1 \\
\hline 21 & Mar 2014 & Ogor Ikem & Crime & $\begin{array}{l}\text { Members of a cultural } \\
\text { troupe were hired to } \\
\text { perform at a burial cer- } \\
\text { emony and disagreed } \\
\text { over sharing the money. } \\
\text { One of them ran home, } \\
\text { brought a gun, and shot } \\
\text { dead a colleague. }\end{array}$ & 1 \\
\hline 22 & 2014 & Neke & Land dispute & $\begin{array}{l}\text { An ongoing land dispute } \\
\text { between Ikem and Neke } \\
\text { claimed one life. }\end{array}$ & 1 \\
\hline
\end{tabular}

Source: Fieldwork, October 2014

We can see from Table 7.4 that at least 28 violence-related deaths took place in Isi-Uzo LGA within the time frame covered by this study: 17 from crime, four from land disputes, three from religious issues, two from sorcery, and two from accidents (Figure 7.4). Data on Isi-Uzo indicate that the trend in fatalities fluctuated and decreased in 2012, 2013, and 2014. This challenges the notion that people usually remember recent incidents more than older ones. Whether or not this was as a result of actual reduction in the number of fatalities in Isi-Uzo, the study could not determine. As in Aninri, almost all of the cases were not reported by the press. Motor accidents, in particular, did not make the news. However, terrible accidents occur on a weekly basis on a stretch of $2 \mathrm{~km}$ between Eha-Amufu and Mgbuji, which happens to be one of the very few tar roads in Isi-Uzo LGA. According to a chief of the community: 'There is no week we do not record up to five motorcycle accidents, especially on our market days. Within the last two years, we have witnessed numerous accidents that have resulted in about four deaths on that road.' Motorists have also not helped matters, as they are said to often over-speed.

Comparatively speaking, there were fewer motor and motorcycle accidents in Isi-Uzo than in Aninri. Roads leading to most of the communities in the latter are in a very good state, and this, unfortunately, has predisposed motorists to reckless driving and Aninri recording higher fatalities resulting from road accidents. 
Figure 7.4 Percentage of causes of violent deaths in Isi-Uzo LGA (June 2006-May 2014)

Percentage of causes of violent deaths in Isi-Uzo LGA (June 2006-May 2014)

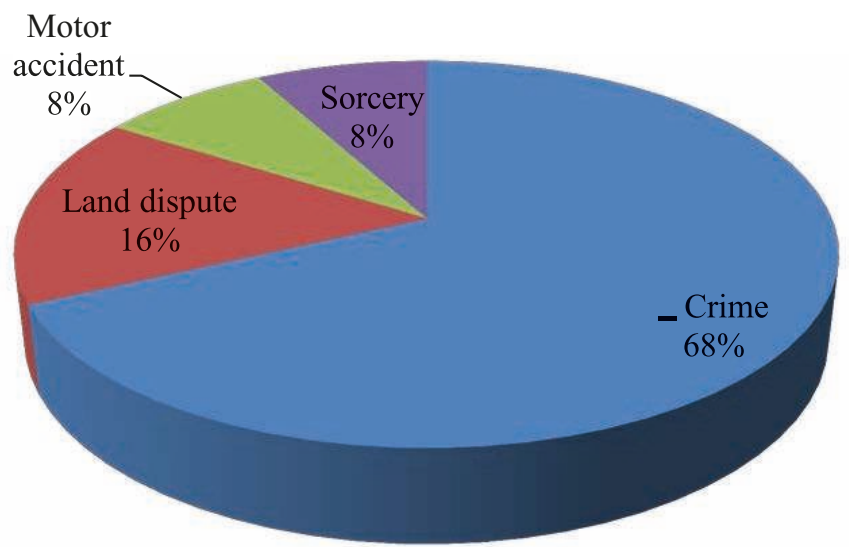

Source: Fieldwork, October 2014

The majority of Isi-Uzo respondents $(83.3 \%)$ agreed that the national press neglected events in their LGA. Only 3.3\% disagreed, while $13.3 \%$ indicated that they did not know. When asked why the national press neglected Isi-Uzo, 83.3\% mentioned factors such as impassable roads, lack of urban centres, the distant location from the state capital, and the absence of economic benefits for the media.

\section{Conclusion}

While carrying out fieldwork in all the communities of Aninri and Isi-Uzo LGAs during 27 days, the researcher could not find a single journalist except on Sunday, 19 October when several of them accompanied Senator Ike Ekweremadu, the Deputy President of the Senate, to his country home at Mpu in Aninri. One of the traditional rulers interviewed observed sadly: 'Rural areas like ours do not make news in Nigeria because politicians do not reside here.' Thus, a female journalist in Enugu metropolis stated:

As a journalist, I cannot just get up from here in Enugu and go to those places if I do not have a special project. For example, since the people of the two LGAs are mainly farmers, I could take up a project on agriculture to find out how they plant rice and how challenging it is for them to procure fertilizer. I could also go there if I have a special interview with a par- 
ticular politician. So, before a journalist decides to report a particular rural community, something must have propelled her or him, because there are fewer activities there.

It is agreed that a rural society may not necessarily be as violent as a cosmopolitan city like Enugu, where anonymity encourages violence and crime. Yet fatal incidents do happen in remote places. To bridge this information gap, respondents in FGDs suggested that media houses should train and employ selected persons from local communities to serve as their reporters. However, a senior male journalist in the office of the chairman of the Nigeria Union of Journalists (NUJ), Enugu State Chapter, disagreed because of the prevailing cost:

Inasmuch as it would be proper to station reporters in these LGAs who are indigenes and would now transmit information to their offices in the state capital, media houses cannot afford it. Government should reduce tariff on printing materials to enable more newspapers, including community newspapers, to come on board; and then it would be easier for the owners of existing newspapers to save some money to be able to give employment to more people, especially in rural communities.

To conclude, it is thus clear that fatal incidents are rarely reported by the national press, yet are part of people's living experiences in Aninri and Isi-Uzo LGAs. These shortcomings, some argued, are due largely to the fact that rural communities hold little or no economic value for the media. Besides, most incidents resulted in one or two deaths maximum - not enough to attract the press. 


\title{
A Survey of violence-related deaths in Egbedore and Ifedayo LGAs of Osun State (2006-2014)
}

\author{
Hammed Abodunrin
}

\begin{abstract}
Egbedore and Ifedayo LGAs are rural communities that do not attract media attention, yet they have their share of violence leading to loss of lives. This paper focuses on these deaths, their causes, and the reasons such incidents were not reported by the national press. A non-probability sampling technique was adopted for this study, using both incidental and purposive sampling, to source information from people who were accessible and based on the researcher's choice. Virtually all the respondents (100\% in Egbedore and $88.9 \%$ in Ifedayo) considered the study areas non-violent. However, nine and 13 violent deaths were recorded in Egbedore and Ifedayo LGAs, respectively, during the period under review. These incidents resulted mainly from communal clashes, land disputes, and road accidents due to bad roads. Interviews conducted with journalists covering the State of Osun ${ }^{1}$ revealed that almost all media houses represented in the state had one reporter to cover 30 LGAs and one area council. A number of reasons were advanced for not covering the councils adequately: there were claims of poor and irregular salaries - and hence an inability to make frequent visits to remote parts of the state - lack of community newspapers, bad roads and poor transportation services, and an uncooperative attitude from security operatives in regard to releasing information. In addition, journalists pointed to different media house styles, which see some stories as not weighty enough to make national news.
\end{abstract}

\section{Introduction}

Violence is a global problem confronting all parts of the world, with attendant negative effects on lives, property, and the environment. While quite a number of direct violent occurrences in terms of wars, insurgencies, and terrorist actions, among other high-profile destructive acts, are being witnessed in places like Syr-

1 The administration in the state changed the name from Osun State to the State of Osun in 2011. 
ia, Central African Republic, and Nigeria, other lethal violent events also abound and, in many cases, pass unnoticed. These include violent communal clashes, riots, armed banditry, arson, ritual killing, and related extra-judicial killings, which remain 'invisible' since they are not recorded or accounted for. This work conducted a survey of such 'invisible' violence, including violent deaths caused by accidents, in Egbedore and Ifedayo LGAs of the State of Osun from June 2006 to May 2014.

\section{The study areas}

\section{Egbedore}

Egbedore LGA covers an approximate area of $102 \mathrm{sq} \mathrm{km}$ in the State of Osun. It has its headquarters in Awo, about $12 \mathrm{~km}$ from Osogbo, the state capital. Created in 1989 from the old Ede LGA, Egbedore is one of the largest LGAs in the state and has many historical towns, including Ido-Osun (which hosted the first aerodrome in Nigeria), Ara, Ojo, Iragberi, Ofatedo, Idoo, Ekuro, Iwoye, Aro, Okinni, and Olorunsogo. The LGA's population was put at 73,969, according to the 2006 population census. The population is, no doubt, enhanced by the proximity of some of the towns in the LGA to Osogbo, the capital of the State of Osun. Like others in the state, Egbedore also has a homogenous Yoruba population of Oyo extraction. As a result of the closeness of some of the towns such as Ofatedo, Ido-Osun, Okinni, and other minor settlements to the state capital, the LGA is inhabited by other Nigerians and foreigners, especially from the West African sub-region.

The locals are predominantly farmers, cultivating both food and cash crops. They also practise fish farming and raise poultry, with many non-indigenes participating. According to the council's information handbook, the LGA has been identified by the State of Osun's Ministry of Commerce and Industry as possessing large quantities of granite, talc, laterite, and precious stones. Miners' activities are noticeable in many parts of the LGA, especially around Awo, the headquarters where talc is suspected to be in large deposits, and in Iwoye, Egbedi, Ido-Osun, Okinni, Idoo, and other towns and villages where granite, gravel, and sand are being extracted for construction purposes.

There are also commercial activities that thrive in the LGA. As a matter of fact, the area played host to the state's trade fair complex located in Ido-Osun, where the then joint trade fair among all Odua states-Oyo, Ekiti, Ondo, and Ogun-was held on a rotational basis. The complex is currently being reconstructed as an ultra-modern market by the state government. There are small businesses that engage artisans such as mechanics, tailors, and bricklayers, as well as commercial motorists and cyclists. 
Politically, the LGA is divided into ten wards, each producing a councillor to represent it at the council's legislative arm. The wards are distributed among the towns and villages that constitute the LGA as follows: Awo/Abudo, Ara I, Ara II, Ido-Osun/Egbedi, Iragberi I, Iragberi II, Iwoye/ Ekuro/ Idoo/Origo, Ikotun/Olope, Ojo/Aro, and Okinni/Ofatedo/Olorunsogo. ${ }^{2}$ Since the commencement of the fourth republic, the chairmanship position in the LGA is rotated among the indigenes of the major towns. Individual towns and villages are also administered traditionally by the obas (kings) and chiefs, who essentially handle non-violent conflicts and other civil matters that may be referred to them. There are two prominent religions, Christianity and Islam, as well as the traditional religions in various constituent communities.

As a result of the proximity of some of its settlements to the state capital, the LGA enjoys many of the benefits of the developments around the seat of power. Among these are relatively regular electricity, potable water, communication and transport facilities, and other physical and economic development programmes. For instance, Ido-Osun, one of the towns in the LGA, currently hosts the state office of the National Communication Commission, a proposed international airport (under construction), the relocated sawmill and plank market, and a new international market complex (under construction). In addition, junior and senior government workers, as well low- and high-level income earners in the private sector, now see some satellite towns in the LGA as alternative places to reside and are building their houses in the area. Towns like Ofatedo, Okinni, Ido-Osun, Olorunsogo, and up as far as Egbedi are being rapidly built up to provide accommodation to people who work in the state capital.

However, these developments are also a source of violence in various forms in the LGA. As a result of the pressure on land, competition has become so severe that both inter- and intra-community clashes have sometimes led to deaths. Furthermore, the volume of traffic as well as the pressure on villagers to improve their incomes to compete favourably with the new settlers in the market are additional sources of problems. This has also led to traffic-related deaths in the council area.

\section{Ifedayo}

Ifedayo LGA was carved out of the old Ila LGA in September 1991, as noted in the Federal Government Gazette No. 54 of 2 October 1991. This border LGA in the State of Osun shares boundaries with Kwara and Ekiti states, thus making it the farthest from the state capital at Osogbo. Ifedayo has only two major towns:

2 Egbedore local government website. http://www.egbedore.com/overview.php. Accessed 2 October 2014. 
Ora, reputed to host the first church (built in 1895) in the area; and Oke-Ila, the LGA's headquarters. There are adjoining villages, such as Ooyi-Aduni, Ayegunle, Idi-Awewe, Ayedaade, Ejifunmi, Temidire, Alagbede, Idi-Odan, Agunsoro, Isimi-Ehinle, and Baasin/Arutu. All these are grouped together and called 'Leesiti' by the locals, which is a bastardized pronunciation of 'less cities'. The LGA has an area of $128 \mathrm{sq} \mathrm{km}$. According to the 2006 census, Ifedayo has a total population of 37,058. Apart from a few settlers from the northern and eastern parts of Nigeria, who mainly practise farming and supply labour to the indigenous farmers, the LGA has a homogenous population, mainly of the Igbomina subethnic group of the Yorubas.

Ifedayo has a predominantly agrarian economy, as the tropical rain forest supports farming, especially in the areas of food and cash crop production. Food crops, however, including yam, cassava, maize, rice, and vegetables, are still being grown in many cases at the subsistence level. Farmers bring only the excess for sale to the markets. It is somewhat better in the areas of cash crops, especially cocoa and kola nuts, as well as oil palm. The majority of the farmers in Ifedayo still use old implements and human labour to manage their farms and to process agricultural products such as palm kernels. In addition, many of the farms are inherited.

Other economic activities include petty trading, especially among the women, and the transportation business, dominated by young commercial motorcyclists. These transport businesses provide services to the likes of LGA workers, teachers, paramedics, and security operatives, consisting mainly of the Nigerian Police and the Nigerian Security and Civil Defence Corps. There were very few commercial vehicles plying routes in the LGA.

Some Fulani cattle herdsmen have also settled in some of the Lessiti villages, where they rear their cattle and practise some form of food crop farming, mainly maize and millet cultivation. Their women earn their living by selling cheese produced from cow milk. The nature of this occupation, where animals are moved from one point to another to graze, has on some occasions caused conflicts between local farmers and the herdsmen settlers.

The LGA can also boast of civil and public servants who work in its council secretariat, seven secondary schools (including three privately owned), two state hospitals (in Oke-Ila and Ora), the maternity units in Lessiti, waterworks, the presence of the security services of police, civil defence, Department of State Security (DSS), and the Immigration Service. A major tourist attraction that occasionally draws visitors to the LGA is Ayekunugba waterfall. ${ }^{3}$

Being a border LGA, commuters find the Osogbo-Ila-Ora road, which links the state to Otun Ekiti in Ekiti State, especially convenient when going to Abuja.

\footnotetext{
3 Ayekunugba is the name given to the waterfall located in Oke Ila Orangun.
} 
This has been a source of problems to the people of the area for various reasons. The volume of traffic, including heavy-duty vehicles, increases drastically each time the road is reconstructed and has consequently shortened its lifespan, as is noticeable at present. Secondly, due to the hilly nature of the road, with its many sharp bends especially between Ila and Ora, road accidents can be fatal. This is worsened when the road becomes bad during the rainy season. Commuters who use the link to their destinations do not normally stop, except on the occasions when their vehicles develop a fault that prevents them from moving further. Residents also occasionally stop to buy farm products such as plantains and, at times, cheese from herdsmen's wives and children who hawk them along the roads.

The LGA has two prominent religions: Islam and Christianity. There are also traditional religions and festivals. Thus, aside from the celebration of Christmas and Eid-kabir by the Christians and Muslims respectively, Egungun, Oro, and Isagun $^{4}$ are held at their appointed times. Like any other typical Yoruba settlement, the two major towns are ruled by the traditional rulers (obas) and their chiefs. The headquarters, Oke-Ila, is headed by the Orangun of Oke-Ila. However, Ora unusually has two obas. Both have separate palaces on either side of the only road that links the town to Ila Orangun. Entering the town while coming from Ila reveals the palace of the Akesin $^{5}$ of Ora-Igbomina to the right, while that of the Asaoni ${ }^{6}$ of Ora-Igbomina is to the left. The unresolved historical conflict over who should be the paramount traditional head of the sleepy community has occasionally led to violence in the past, resulting in destruction of property and loss of lives on both sides.

Politically, Ifedayo is divided into ten wards, mainly shared among the two towns. These are Oyi Ayegunle, Ayetoro, Isinmi olootu, Balogun, Obaale, Aworo/Oke-Ila Rural, Asaoni, Akesin/Otun, Akesin/Oja/Ora, and Akesin/ Temidire. These are designated wards 1 to 10 , respectively. They are all represented by either elected or appointed councillors at the council's legislative arm. The council is headed by an elected or appointed chairman, as the larger political situation in the state may dictate. For instance, since the dissolution of the last elected chairmen in all the LGAs in the State of Osun about four years ago, local government elections have not been held. As such, operators of the executive arms of the local governments have been the appointees of the governor.

Ifedayo LGA, especially Ora, has produced many prominent Nigerians in the political sphere, including a Nigerian Ambassador to the Philippines, Dr. Yemi Farounbi, and a senator representing Osun Central senatorial district, Professor Sola Adeyeye.

\footnotetext{
Egungun, Oro, and Isagun are forms of masquerades celebrated in Ifedayo communities at regular intervals.

Akesin is the title given to the traditional ruler of Ora by one side of the indigenes.

Asaoni is the title given to the traditional ruler of Ora by the other side of the indigenes.
} 


\section{Objectives of the research}

The main objectives of the research were as follows:

1. To discover the number of violence-related deaths that occurred in the study areas between 2006 and May 2014.

2. To discover the causes of such violent deaths.

3. To discover whether or not such deaths were officially reported at appropriate quarters such as security operatives' offices and hospitals.

4. To discover reasons why such violent deaths were not reported in the media.

For the purposes of this research, violent deaths in the period under review include those that resulted from disasters, road crashes, drownings, being trapped at mining sites, and fire incidents, in addition to fatalities caused by interpersonal disputes, communal clashes, and attacks. The mismanagement of conflicts was also studied.

Since Egbedore was created from the old Ede LGA, its constituent communities that share boundaries with the mother council, such as Awo and Ido-Osun, have been in constant disputes. Also, like any value-based conflict, the chieftaincy rift over who should be the paramount ruler of Ora in Ifedayo LGA, between the persons bearing the Akesin and Asaoni titles, seems difficult to resolve once and for all and requires constant management.

\section{Media reports and gatekeeping theory}

Media is defined by O'Sullivan (1991) as an intermediate agency that enables communication to take place and a technological development that extends the channels and range of speed of communication. It can also mean 'those institutional structures that foster the rapid transmission of standardized information to a relatively large audience through some mechanised channels or medium' (Ike 2005). In a nutshell, the media is responsible for the dissemination of information among people, while it also takes their reactions in the form of feedback, with a view to making such feedback available. The media is the link, that is, the channel of communication, that ensures a successful journey of the code from the sender to the receivers, who then decode the message and respond in the form of feedback, thus making it an information chain.

Whether or not a piece of information will make it into the public arena is always a painstaking activity in the media. The volume of information available to any medium is enormous, and hence the need to prune it down to allow the most important items to see the light of day, while other items have to wait temporarily or forever. In taking this decision, there are sets of rules and regulations to be followed, including ethical considerations and the public interest. The process is 
referred to as 'gatekeeping', and it manifests at every level of the media, that is, from the reporters in the field who decide which information should be gathered, processed, and sent to the news editor, and the editor who has the final say regarding publication. Ekeli in Folarin (1995) summarized it thus:

Gatekeeping is nothing but self-censorship performed by the media themselves. Gatekeeping emanates from the understanding by the journalists that apart from legal restrictions on what is to be published, including photographs, journalists have a moral right to be socially responsible to their readers in whatever materials they package for them.

The essence of gatekeeping therefore is to ensure relevant, factual, and responsible information is disseminated to the reading public. However, in reality, gatekeeping is far more complex. There are many factors other than the need to ensure factual, relevant, and balanced information. For instance, a one-time correspondent of Time magazine in China, Teddy White, was reported to have put a sign in his office: 'Any resemblance between what is written here and what is printed in TIME magazine is purely coincidental' (Kunczik 1988, cited in Folarin 1995). Even the editor of the magazine himself was also once quoted to have said: 'I don't pretend this is an objective magazine. It's an editorial from the first page to the last and whatever comes out has to reflect my view and that's the way it is' (ibid.).

Without doubt, whatever is eventually published in the newspapers or broadcast in the electronic media is largely determined by the reporters and, more importantly, by their editors. Speaking about editors, Bolawole (2004, cited in Arogundade 2004) said the following:

Editors are different kettles of fish. Some are bold and brave, some are adventurous and idealistic. Some are practical down to earth realists of the present-day Nigeria. Some are conscious of the naira value of the seats on which they sit while some are conscious of their place in history.

There are other factors, however, that may act naturally as gatekeepers, beyond the control of the reporters and their editors. These may include unforeseen circumstances such as disasters, including crashes, floods, or fire disasters, that can cause damage to the materials intended for broadcast or publication. The reporters themselves can be victims of such mishaps. In addition, there can be technological problems in terms of communicating the gathered information to the newsroom and even the processing of the information for the public (Abodunrin 2007).

Another uncontrollable gatekeeper in this category is the consumer. Even when reporters and editors make news stories available, consumers may not listen to or read them. This is referred to as selective consumption (Folarin 2005). This may include the boycott of certain media products in protest, or the consumer may simply have preferences for other media outlets. 
Again, the media thrive on information, which is, relatively speaking, a perishable item. If the media is unaware of a particular development, such a development can go unreported. Nobody can give what is not available. However, as noted by Bello (2007), the gate must be opened wide, especially for partnership. This will allow the media not only to report disasters but also to render early warning (EW) services such as educating the public, sharing information about affected areas, and alerting government.

\section{Methodology}

\section{Sources of data}

Broadly speaking, the data for this work were derived from both primary and secondary sources. The primary sources included the administration of questionnaires and interviews. Secondary sources were records from security operatives, local government authorities, and Internet resources (the study areas' website pages).

\section{Sampling techniques}

A non-probability sampling technique was adopted for this study. Thus, both incidental and purposive sampling employed sourced information from people who were accessible and based on the researcher's choice. This was as a result of the need to get accurate and official angles on the data collected. Among the people accessed were members of the National Union of Road Transport Workers (NURTW) and selected community leaders, while security operatives were purposively selected. The necessity for purposive selection was as a result of the fact that, by their mode of operation, not all officers and personnel of security services were authorized to provide information. In addition, certain services tended to decline to provide information in any form, for what they always referred to as 'security reasons'.

Thus, personal interviews were conducted with stakeholders. Four focus group discussions (FDGs) were conducted with members of the NURTW operating in Egbedore and Ifedayo LGAs. Key informant interviews (KIIs) were also conducted with journalists working in the state, as well as with security operatives and health workers. 


\section{Data analysis and presentation}

This research aimed to answer two basic questions:

1. What types of violence are recorded in these 'invisible' LGAs?

2. Why are these LGAs neglected by the national press?

These and sundry other questions, such as causes of the violence recorded, are discussed using simple descriptive statistical analysis.

\section{Egbedore LGA}

Despite frequent land disputes among the people of this area, it is still considered not violent by all the respondents, including security operatives, community leaders, and organized union members. Twenty copies of the questionnaire were distributed purposively, as explained above, and 17 were returned. All the respondents answered 'No' to the question: 'Do you consider your neighbourhood to be violent?' The reasons for this were explained thus by a respondent from Ido-Osun, who said he had lived in the community for over 40 years:

Generally, Egbedore is peaceful, if not for the issue of land disputes that occurred occasionally. If there is land tussle, we refer the case to the palace for settlement. Whoever sells to more than one person would either be made to refund money or provide another parcel, except the buyer refuses. The major land issue here is caused by the government. They should have come up with a definite policy that will show who owns the land where the airport is being built. That is the major problem for now. The youth from Ede wanted to claim IdoOsunland, and the youths here resisted them. The government owns the land; but when the airport is ready, it should bear the name of Ido-Osun.

Another respondent at Okinni, who also described Egbedore as peaceful, noted:

The major problem here is land, because many civil servants in Osogbo have been building their houses here and Ido-Osun because of their nearness to the state capital. Family members at times fought, and the ones they could not resolve were reported to the police. There was an occasion or two when people went violent, but the police arrested the suspects and I don't know the latest now.

\section{Types of violence in Egbedore}

Although Egbedore cannot be said to be a violent LGA, it has had its own share of deaths. Broadly speaking, the reported fatal incidents can be categorized into natural disasters, accidents, and crime, including clashes. Table 8.1 below shows the recorded violence and deaths in Egbedore LGA between February 2012 and May 2014. There were no records, especially from official angles, to show these types of violence and deaths from 2006 to 2011 in the LGA. The only violent conflict that came close was in 2003, when the community and the police clashed over the alleged repeated arrest of residents for no just reasons. Matters came to a 
head in February 2003, when irate members of the community burnt the part of a private building being used as the police station and then chased the policemen away. The residents took over the security of the town for about ten years until a police post was recently built in the $o b a$ 's palace. For the residents interviewed, the fact that they could do without policemen for about ten years was a pointer to the non-violent nature of the community and its environs.

Table 8.1 Violence types and fatalities in Egbedore LGA (February 2012-May 2014)

\begin{tabular}{|c|c|c|c|c|}
\hline Date & Town / location & Type of violence & Remarks & No. of deaths \\
\hline 29 Feb 2012 & Ido-Osun & Drowning & $\begin{array}{l}\text { Victim drowned } \\
\text { while swimming at } \\
\text { Kosa River }\end{array}$ & 1 \\
\hline 15 Mar 2012 & Awo & Mining accident & $\begin{array}{l}\text { A miner trapped at } \\
\text { site }\end{array}$ & 1 \\
\hline 10 May 2013 & Ido-Osun & Drowning & $\begin{array}{c}\text { 19-year old } \\
\text { drowned in Kosa } \\
\text { River }\end{array}$ & 1 \\
\hline 11 June 2013 & Awo & Road accident & $\begin{array}{c}\text { Blood-stained } \\
\text { woman's body } \\
\text { found along Iwo } \\
\text { Road } \\
\end{array}$ & 1 \\
\hline 13 Sept 2013 & Ido-Osun & Road accident & $\begin{array}{l}\text { A vehicle hit two } \\
\text { soldiers riding a } \\
\text { bike }\end{array}$ & 1 \\
\hline 6 Nov 2013 & Iwoye & Road accident & $\begin{array}{c}\text { Auto crash killed a } \\
\text { passenger }\end{array}$ & 1 \\
\hline 9 Nov 2013 & Ido-Osun & Land dispute & $\begin{array}{l}\text { Man macheted, } \\
\text { later died in his } \\
\text { room }\end{array}$ & 1 \\
\hline 28 Feb 2014 & Ofatedo & Road accident & $\begin{array}{c}\text { A male victim } \\
\text { killed }\end{array}$ & 1 \\
\hline 21 Mar 2014 & Okinni & Land dispute & $\begin{array}{c}\text { A male victim } \\
\text { hacked to death } \\
\text { over a land dispute }\end{array}$ & 1 \\
\hline
\end{tabular}

Source: Fieldwork, August-September 2014

From Table 8.1, one can see that a total of nine deaths were recorded in five communities during the period under review. Out of these, only two were as a result of land disputes, which was in line with the relatively peaceful nature of the LGA. Following the pattern of Nigeria nationwide, road accidents remained the main problem and accounted for four deaths. ${ }^{7}$

7 See Chapter 1. 


\section{Summary of findings}

As noted earlier, both Egbedore and Ifedayo LGAs of the State of Osun were under-reported in the last ten years as far as violent deaths are concerned. Although this research could not assess any record of violent deaths between 2006 and 2008, the following incidents were discovered between November 2009 and June 2014:

(a) Awo

1. Awo (the headquarters of Egbedore LGA) and Ede (the headquarters of both Ede North and South LGAs, from which Egbedore was created in 1989) engaged in nonlethal clashes in November 2009 and January 2010 over boundary disputes. Security operatives were drafted to the location on both occasions to prevent escalation.

2. As explained above, the LGA is endowed with mineral resources such as talc, granite, and limestone. On 15 March 2012, a worker of Sunny James Construction Company named Sunday Gbenga was trapped while working at the mining site excavating certain types of precious stone. Indiscriminate diggings dot the environment and continue to pose threats not only to these miners but to other people and to animals in the area.

3. On 11 June 2013 the corpse of a woman was found with blood stains along Awo-Iwo road in Awo. She appeared to be the victim of hit-and-run driver.

(b)Ido-Osun

1. Ido-Osun shares a boundary with Ede, which hosts the state's waterworks. On 29 February 2012, an Ayo drowned while swimming in Kosa River, one of the tributaries to Osun River.

2. On 10 May 2013, another person, a Class 5 YTD primary school student named Niyi Isiaka, also drowned in Kosa River (which was overflowing because the dam across Osun River was opened). He was recovered the following day by Hausa fishermen because the fire fighters could not retrieve him on the first day.

3. On 13 September 2013, a vehicle, number KSF976QC, knocked two soldiers off the Honda bike they were riding along Ido-Osun Ede road in Ido-Osun. One of the men, a 28-year old named Ibraheem, died instantly.

4. On 8 November 2013, a riot broke out between Ido-Osun and Ede over the name of the airport under construction, as the two communities lay claim to the land. A man named Fatai Oyedeji, who was reportedly attacked with machetes during the fracas, died the following day.

(c) Ofatedo

1. On 28 February 2014, a male victim called Fawad was crushed by a vehicle reported to be travelling at top speed.

It should be noted that Ofatedo is a community that is so close to Osogbo that, unless one is told, one cannot know it is a separate town from the state capital. 


\section{Ifedayo LGA}

Ifedayo is a typical rural LGA. Apart from being a border settlement far from the state capital Osogbo, the hilly, windy, and pot-holed road from Ila Orangun makes it devoid of the hustle-bustle characteristic of cities. The LGA can also be said to be peaceful, as 16 of our 18 respondents attested to this. Only one respondent, a road safety official, insisted that it is 'not a Yes or No answer'; some road users, especially commercial motorcyclists, popularly called okada riders, were violent in the way they used the road. Another respondent did not answer. The peaceful nature of the LGA was corroborated by a community leader in OkeIla:

We have no problem here at all. We sometimes disagree, but that is normal. Even tongue and teeth, as close as they are, do fight, and when the teeth bites tongue none of them will leave, the wound will be healed, and this does not happen always. Our only problem is bad road and other developments.

Also in Ora, an FGD conducted among commercial motorcyclists revealed that the LGA was relatively peaceful. A participant said the only problems they had were bad roads and the numerous domestic animals, especially goats, that competed with them on the roads.

The LGA's major source of conflicts has been the age-old chieftaincy rift between the Akesin and Asaoni of Ora, who have been laying claims to the kingship of the sleepy town. The peak of the violence was in 2004, when both sides clashed and destroyed lives and property. They have since been avoiding a repeat. According to a community leader in Ora:

It is true we once fought, but that was long ago. We are now united; in fact, the Asaoni that just died and the current Akesin were good friends, and they visited each other's palaces. I think we are more concerned about our seeming neglect now than chieftaincy issues.

Despite these opinions, Ifedayo also had incidences of violence that led to deaths in the period under review, as shown in the Table 8.2.

Out of a total of 13 deaths recorded during the period under review, Alagbede (one of the villages called Leesiti) had seven, while Ora and Oke-Ila had three each. Eesikin, a border village between the LGA and Ekiti, also had one death. Only four of the deaths could be traced to clashes, thus justifying the claim of the respondents that the LGA was peaceful. Road accidents were the cause of the highest number (8) of violent deaths, while the remaining one death could not be traced to a definite cause. 
Table 8.2 Violence types and fatalities in Ifedayo LGA (December 2009-September 2014)

\begin{tabular}{|c|c|c|l|c|}
\hline Date & Town/location & $\begin{array}{c}\text { Type of vio- } \\
\text { lence }\end{array}$ & Remarks & No. of deaths \\
\hline 8 Dec 2009 & Ora & Clash/attack & $\begin{array}{l}\text { Police/NURTW } \\
\text { clashed at check- } \\
\text { point }\end{array}$ & 3 \\
\hline 4 July 2011 & Eesinkin village & Clash/attack & $\begin{array}{l}\text { Herdsmen/farmers' } \\
\text { clash killed one } \\
\text { man }\end{array}$ & 1 \\
\hline 20 July 2013 & Ora & Road accident & $\begin{array}{l}\text { Goat obstructed a } \\
\text { speeding cyclist }\end{array}$ & 1 \\
\hline 23 Oct 2013 & Alagbede Hill & Road accident & $\begin{array}{l}\text { Motorcycle acci- } \\
\text { dent killed rider }\end{array}$ & 1 \\
\hline 18 Nov 2013 & Alagbede Hill & Road accident & $\begin{array}{l}\text { A tanker skidded } \\
\text { off the road }\end{array}$ & Nil \\
\hline 22 Dec 2013 & Alagbede Hill & Road accident & $\begin{array}{l}\text { A bus's brakes } \\
\text { failed, killing a } \\
\text { passer-by }\end{array}$ & 1 \\
\hline 24 Dec 2013 & Alagbede Hill & Road accident & $\begin{array}{l}\text { A bus crashed, } \\
\text { killing 5 and injur- } \\
\text { ing 7 }\end{array}$ & 5 \\
\hline 3 Feb 2014 & Alagbede Hill & Road accident & $\begin{array}{l}\text { A asphalt-laden } \\
\text { truck skidded off } \\
\text { the road }\end{array}$ & Nil \\
\hline 26 May 2014 & Oke-Ila & $\begin{array}{l}60 \text {-year old man } \\
\text { found dead on a } \\
\text { farm }\end{array}$ & 1 \\
\hline
\end{tabular}

Source: Fieldwork, August-September 2014

\section{Summary of findings}

Ifedayo is a rural LGA and a relatively peaceful area. The major source of violent deaths was accidents due to bad roads. Of the 13 deaths recovered during the period, eight $(61.5 \%)$ were a result of road accidents. It is instructive to also note that of the six road accidents recorded during the period under review, five occurred around Alagbede Hill, thus marking the place as disaster-prone. Details are as follows:

(a) Ora

1. The most outstanding of the clashes/attacks recorded in the period under review was the clash between the police and the NURTW on 8 December 2009. One of the policemen at the checkpoint on the outskirts of Ora town, towards the border with Kwa-

8 Prior his death, the deceased was said to have had a serious misunderstanding with a suspected hoodlum, who is now at large after allegedly killing a community night guard. However, the cause of the old man's death has not been conclusively established. 
ra, was reported to have shot a driver dead. The deceased was said to be a leader of the NURTW in the town who had gone there to intervene on behalf of one of the members that was arrested. Other union members mobilized themselves and, in a reprisal attack, killed two policemen.

2. On 20 July 2013, goats obstructed a commercial motorcycle that also carried a passenger. The rider died immediately. Competing with goats on roads is a common event in this LGA.

(b) Alagbede Hill

1. On 23 October 2013, a motorcycle accident claimed the life of the rider.

2. Again, on 18 November 2013 on this hill, a tanker skidded off the road and ran into an oncoming bus, damaging it. No life was lost.

3. On 22 December 2013, a bus marked Lagos XF507 LND had a break failure and killed a passer-by.

4. On 24 December 2013, a Toyota Hiace Hummer bus crashed on this hill, killing five of its passengers and injuring seven.

5. On 3 February 2014, a truck marked YRE320XA and loaded with asphalt skidded off the road, but there were no casualties.

(c) Oke-Ila

On 26 May 2014, a 60-year old man was found dead at his farm.

\section{Why are these LGAs neglected by the national press?}

The second main question this research aimed to answer was this: Since all the aforementioned incidents actually occurred, why did the press not capture them? Interviews conducted among members of the press corps in the State of Osun were quite revealing. Some of the factors responsible for such neglect included the following:

\section{Inadequate personnel}

It was discovered that of the approximately 22 media correspondents stationed in the state to represent various media houses in Nigeria, only one of the media houses, the News Agency of Nigeria (NAN), has more than one reporter. Thus, newspapers, including the Nigerian Tribune, Vanguard, ThisDay, Daily Independent, Daily Trust, Newswatch, The Union, Punch, The Guardian, National Mirror, Pilot, and The Sun, have only one correspondent each to cover the entire state with its 30 LGAs and one area office. The journalists were not always aware of many of the things that happened; consequently, they could not report them. 


\section{News judgment}

Reporters, who are the editors in the field, also exercise their privilege to determine what news is. For instance, one of the participants exclaimed during the FGD:

How do you think I will travel for about four hours to Oke-Ila because one old man died in the bush? And, if I should miss another important story, like a minister's visit to the state, you think my editor will be happy?

\section{News value}

Another reason advanced for the seeming neglect of the study areas was that some of the happenings were not 'weighty' enough to get space in the national newspapers. According to one FGD participant: 'The death of an okada rider would be meaningless if I sent it in this era of Boko Haram and, lately, Ebola saga.' He advised that 'only community newspapers can capture those things adequately'.

\section{Over-reliance on official sources}

Many correspondents covering the state live in Osogbo, the state capital. Many of them believe that as all the security agencies are based in Osogbo, the important incidents will surely land on the head's table. If such incidents are newsworthy, the press will surely be invited.

\section{Accessibility problem}

There is also the problem of access, especially to Ifedayo LGA. For instance, Oke-Ila, a distance of about $100 \mathrm{~km}$ from Osogbo, could take a reporter the whole day to visit and come back, using commercial transport. This is because the few buses that ply the route have to wait until their seats are filled before leaving the bus park. This may take between 30 minutes and one hour, depending on the time of the day. In addition, commuters going to either Ora or Oke-Ila need to break their trips and have a stopover at Ila. Few vehicles, between one and three, ply the Oke-Ila-Ora route, and the passengers need to again wait in Ila. However, commercial motorcyclists are filling the gap. Odetoro (2007) identified African topography and road geometry, which result in steep slopes, bends, and pot-holes, as a cause of difficult accessibility. The windy, hilly, and bad nature of the Ila-Ora-Oke-Ila road has always been a menace to commuters; furthermore, the hills and bends were not reconstructed when the road was renovated in 2008. Thus, journalists will not go if they are not invited for special programs, such as the inauguration of projects by the local government or celebrations by certain politicians. 


\section{Uncooperative attitude of security operatives}

When a criminal act is committed, security operatives generally want to conceal it to give them time to conclude investigations. Two members of the press attested to this. They agreed that security operatives would not release information voluntarily except when and where they had solved large crimes and wanted to boost their egos. One of the journalists observed:

When you heard such allegation and called them to react, they at times told you they would investigate and that situation was under control. At times, they would tell you reporting a case like accident could have negative psychological effect. Other offenders also beg them to shield their identity.

This researcher also experienced such attitudes, as many of the operatives gave 'no violence' responses to all questions posed. Some of them agreed to give an official response only after some facts were placed before them. Even then, they still craved anonymity. Security operatives consider that the presence of violence is an indictment of their performance.

\section{Poor pay}

Many journalists are still poorly paid and receive irregular salaries. With their meagre and irregular income, it is therefore difficult for many of them to incur extra expenses to travel frequently to rural areas for news.

\section{Volume of information}

One journalist said the volume of information at the disposal of the newspapers' headquarters at times 'displaces my story'. She gave the example of the okada accident at Alagbede Hill, which somebody told her about and which she actually wrote up and sent to her editor; but it was never published.

\section{Lack of attractive political interest}

The LGAs under review are located in rural areas, except for some parts of Egbedore, which has some of its communities as satellite towns to the state capital. Ifedayo, for instance, is located in the remotest part of the state, sharing boundaries with Ekiti and Kwara states. Although it has prominent sons and daughters that are politicians, they are based in Osogbo. Aside from a few occasions of political rallies or meetings they decide to hold at home, such activities are held outside the council.

\section{Limited economic interest}

Although Ifedayo has a tourist attraction site, Ayekunugba waterfall, the volume of tourists is very low because it has not been properly developed and the road leading to the waterfall is bad. Apart from the modern market and the airport lo- 
cated in Ido-Osun, which were still under construction in August 2014, other parts of Egbedore were built up for private residential purposes. Perhaps the fact that issues of economic interest attract media attention accounts for the partial media coverage of the clash between Ido-Osun and Ede over the site of the proposed airport, a clash that led to one death (a man from Ido-Osun).

As noted earlier, consumers can also act as gatekeepers through selective consumption. For instance, the Daily Sun newspaper of 18 December 2009 reported the violent clash between the policemen and members of the NURTW, which led to the death of three persons. However, if a consumer did not buy or have access to that newspaper, they would not have known of the incident.

\section{Conclusion}

There is no doubt that no society is immune to the occurrence of conflicts; and when such conflicts are not properly managed, they can degenerate into violence. Disasters are also part of human existence, and they can be controlled or mitigated only through proper preparedness and effective management.

As discovered in both Egbedore and Ifedayo LGAs, some violent conflicts over land disputes that claimed lives could have been avoided with an effective EW system. In addition, deaths resulting from road crashes could be avoided if road users heeded warnings. Although poor roads can be a major cause of traffic accidents, bad practices of driving-such as road hogging, tailgating, and ragging ${ }^{9}$-also play a significant role (Akinola 2005). For instance, a road safety officer explained that there was enough 'road furniture' to guide motorists using the Ila-Ora road, furniture which he said was not being made use of. It was observed, however, that some of this furniture were already covered by bush. A typical example of such covered furniture was a large signpost erected by the members of the National Youth Service Corps (NYSC), warning road users of bends, steep slopes, and the need to minimize speed.

Despite the inevitability of these occurrences in some cases, the media cannot, as might be expected, always capture all these events, especially in rural areas. This is a result of a number of factors, ranging from problems of finance, inadequate media personnel, accessibility, right news judgment, lack of communitybased print media houses, uncooperative attitude of security operatives, and other factors highlighted in the research.

\footnotetext{
9 Road hogging is the act of driving without adequate consideration for other road users. Tailgating is driving too close to another vehicle in a 'nose-to-tail' manner. Road ragging is the term used for violent driving in revenge or retaliation for others' bad driving.
} 
However, effective coverage and documentation of such occurrences could be enhanced by having more staff in the media and including community-based newspapers (where they exist) in the process of documentation.

\section{References}

Akinola, A. (2005), Road Traffic in Nigeria: Cases, Causes and Control. Osogbo: D \& G International Limited, pp. 1-25.

Bello, S.A. (2007), Disaster Response Strategy: Civil Protection. Abuja: Sellobell Global Venture, pp. 127-128.

Bolawole, B. (2004), Editorship and Investigative Journalism. In: L. Arogundade, ed., Guidelines and Resources on Investigative Journalism. Lagos: International Press Centre, pp. 1014.

Folarin, B. (1998), Theories of Mass Communication: An Introductory Text. Lagos: SterlinHerden Publishers Nigeria Limited, pp. 18-111.

IFESINACHI, K. (2009), Early Warning System and Conflict Management. In: M. Ikejiani-Clark, ed., Peace Studies and Conflict Resolution in Nigeria: A Reader. Ibadan: Spectrum Books Limited, Ibadan, pp. 103-109.

IKE, N. (2005), Dictionary of Mass Communication. Owerri: Book-Konzult, pp. 138.

LeVInson, M.H. (2006), Anger Management and Violence Prevention: A Holistic Solution. In: Meier (2009) A Review of Foundation for Co-Existence's (FCE) Book 'Third Generation Early Warning'. www.questia.com/library/journal/1G1-145561488/anger-management-andviolence-prevention-a-holistic. Accessed 2 October 2014.

Odetoro, W.K. (2007), We All Had to Run. Prevention, Reduction and Management of ManMade Disasters Around the World. Abuja: Foundation Against Man-made Disasters (Publishers), pp. 28, 242-250.

Osaghae, E.E. (2005), Violence in Africa: State, Ethnic and Regional Dimensions. In: I.O. Albert, ed., Perspectives on Peace and Conflict in Africa, Essays in Honour of General (Dr) Abdusalami Abubakar. Ibadan: Peace and Conflicts Studies (PCS) Programme, Institute of African Studies (IAS), University of Ibadan, pp. 101-118

O'Sullivan, T., ed., (1991), Key Concepts in Communication. London: First published in 1983 by Methuen \& Co. Ltd, pp. 134. 


\title{
A study of violence-related deaths in Baure, Ingawa, Kurfi, Mani, and Matazu LGAs of Katsina State (2006-2014)
}

\author{
Adam Alqali
}

\begin{abstract}
The purpose of this study is to determine the types of fatal incidents in five LGAs of Katsina State: Baure, Mani, Kurfi, Matazu, and Ingawa. The research also interrogates why these areas are neglected by the Nigerian press. The study primarily involved field research (via structured questionnaires) and a review of existing literature on violence, as well as collecting background data on the socio-economic, political, religious, and geographical context of Katsina State. The study revealed 37 incidents of unreported cases of violence, which resulted in 104 deaths in the five 'invisible' LGAs of Katsina State between 2006 and 2014. The causes of these fatalities were road accidents $(63.46 \%)$, drownings $(12.50 \%)$, famer-pastoralist clashes $(6.73 \%)$, building collapses $(4.80 \%)$, assassinations $(3.84 \%)$, fire outbreaks $(2.88 \%)$, animal attacks $(1.92 \%)$, explosions $(0.96 \%)$, and electrocutions $(0.96 \%)$. Kurfi accounts for the highest number of fatal deaths in the five LGAs, followed by Ingawa, Baure, Mani, and Matazu. Essentially, this study identifies the ineffectiveness of press coverage as responsible for the failure of such incidents to make news headlines. A critical look exposes the political economy of the media in Nigeria, with private owners who underpay journalists and see news organs as political platforms to manipulate the unsuspecting masses, to the detriment of poor and marginalized groups in rural areas.
\end{abstract}

\section{Introduction}

According to the World Health Organization (WHO), violence is the intentional use of physical force or power, threatened or actual, against oneself, another person, or against a group or community, which either results in or has a high likelihood of resulting in injury, death, psychological harm, maldevelopment, or dep- 
rivation (WHO 2002: 5). Also, according to the first World Report on Violence and Health from the WHO (ibid. 3):

Violence has probably always been part of the human experience. Its impact can be seen, in various forms, in all parts of the world. Each year, more than a million people lose their lives, and many more suffer non-fatal injuries, as a result of self-inflicted, interpersonal or collective violence. Overall, violence is among the leading causes of death worldwide for people aged 1-44 years. The human cost in grief and pain, of course, cannot be calculated. In fact, much of it is almost invisible. While satellite technology has made certain types of violence-terrorism, wars, riots and civil unrest-visible to television audiences on a daily basis, much more violence occurs out of sight in homes, workplaces and even in the medical and social institutions set up to care for people. Many of the victims are too young, weak or ill to protect themselves. Others are forced by social conventions or pressures to keep silent about their experiences. As with its impacts, some causes of violence are easy to see. Others are deeply rooted in the social, cultural, economic fabric of human life. Recent research suggests that while biological and other individual factors explain some of the predisposition to aggression, more often these factors interact with family, community, cultural and other external factors to create a situation where violence is likely to occur.

The WHO also categorizes violence into three different categories, based on the persons committing the acts of violence: self-directed violence, interpersonal violence, and collective violence (ibid. 6).

Violence or violent activities have always been part of life in Nigeria; and, until recently, road accidents and political clashes were responsible for the highest number of violent deaths in the country. However, the pattern and trend of violent activities and their resultant deaths in Nigeria was greatly altered by the Boko Haram insurgency, which has thus far accounted for the deaths of over 10,000 Nigerians, according to the National Security Adviser (NSA), Sambo Dasuki (Alli 2014). According to Nigeria Watch's Fourth Report on Violence in Nigeria (2006-2014) (2014: 7):

Cumulative figures for the years 2006-2014 show that the main causes of violent deaths are, in order of importance, accidents, crime, political clashes, ethno-religious fighting, and economic issues. In 2014, however, this pattern changed because of the Boko Haram crisis in the North-East. On a national level, political clashes, religious fighting, and crime became the main causes of violent deaths after emergency rule was put in place in May 2013.

Thus, the spate of violent deaths has increased dramatically in Nigeria's northern half since the re-emergence in 2010 of the dreaded Salafist sect, Jama'atu Ahlis Sunna Lidda'awati wal-Jihad (JASLWJ) (lit. 'People Committed to the Prophet's Teachings for Propagation and Jihad', and better known as Boko Haram). Over time, the insurgency is proving seemingly as insoluble as it is intricately difficult to understand. Yet, many other factors account for a significant number of victims of violence across the country. In fact, there are hundreds of cases of violent deaths across Nigeria which have nothing to do with Boko Haram and which result from accidents, natural disasters, and ethno-religious con- 
flicts. While most of these fatal incidents are reported by the media, some never make news headlines.

Katsina State is one of the northern regions affected by the wave of violence occasioned by the Boko Haram crisis. However, it is not one of the areas worst affected by the insurgency, compared with Borno, Yobe, Adamawa, and Kano. No Boko Haram attacks were recorded in the five LGAs under review in Katsina State. In fact, few fatal incidents were reported by the national press in the region between 2006 and 2014. This study attempted to discover why. Was it because there were no such cases in Baure, Ingawa, Mani, Kurfi, and Matazu LGAs? Or was it a result of shortcomings in the system of data-gathering on lethal violence? As expected, the research revealed scores of fatalities in all the five 'invisible' LGAs, proving the ineffectiveness of news coverage by the national press.

\section{Statement of the problem}

Violent deaths resulting from accidents (motor accidents, fire outbreaks, building collapses, drownings), ethno-religious crises, political violence, and various crimes (from assassinations to terrorism) are almost daily occurrences in Nigeria. Katsina State is no exception. In Baure, Mani, Matazu, Kurfi, and Ingawa LGAs, this research revealed many fatal incidents that were not reported by the media, showing a huge gap in the capacity of the national press to effectively cover rural areas. Although most of these LGAs were not necessarily inaccessible and not particularly distant from the state capital, news reporters did not go there owing to serious logistical challenges that confined them to cities-or, to be more precise, to the corridors of power: Government House, government ministries, government departments, and public agencies.

\section{Research questions}

This study responds to two main questions:

1. What are the categories of violent incidents that led to death in the five LGAs under review?

2. Why are the five 'invisible' LGAs neglected by the national press?

\section{Methodology and limitation of study}

After reviewing the existing literature, undocumented violent deaths were identified through interviews with inhabitants of the five LGAs under review. For easier access to respondents, who may not ordinarily be willing to discuss such a sensitive topic, the researcher relied on the leaders of the Nigeria Union of Local Government Employees (NULGE) to select ten inhabitants per LGA and administer a total of 50 structured questionnaires. The investigation also examined why 
fatalities went unreported by the national press. To answer this question, the researcher reached out to the Nigeria Union of Journalists (NUJ).

The study faced a number of challenges, which no doubt affected the outcome of its findings. First, the researcher could have contacted more respondents in other parts of the LGAs but for the limitation in funding. This might have revealed another pattern of unreported violent deaths. Moreover, the investigation was significantly constrained by the lack of available data or literature on 'invisible' violence in rural Nigeria, except for a few available press reports in the archives of Nigeria Watch. Lack of access to adequate literature on the social, economic, political, ethnic, religious, and geographical context of Katsina State left the researcher no option but to gather what was available to him via the Internet.

\section{Ethno-religious and geographical context of Katsina State}

According to the official website of Katsina LGA (Katsina, n.d., para. 15-17):

Katsina was one of the pre-jihad Hausa city states which was conquered and annexed into the Sokoto caliphate by Mallam Urnmarun Dallaji in the early part of the $19^{\text {th }}$ Century. After the British colonial conquest in 1903, the erstwhile Katsina and Daura emirates became Katsina Province of the former Northern Region of Nigeria. Later, Katsina and Zaria Provinces together formed the North Central State under the Gowon regime's twelve-state structure. North Central State was left intact in 1976 when the number of states was increased to nineteen under the new name of Kaduna State. Katsina State came into existence on the $23^{\text {rd }}$ of September, 1987 covering the same area of the former Katsina Province of the defunct Northern Region.

The state now shares borders with Kano and Jigawa states to the east, Kaduna State to the south, Zamfara State to the west, and the Republic of Niger to the north. Its population is predominantly Hausa-Fulani and Muslim. Some 'pagan' Maguzawa live in the southern part of the state along the Malumfashi-KafurBakori axis, although a large majority of Maguzawa have converted to Christianity or Islam. There are also immigrants from the South, mostly of Igbo, Yoruba, and Nupe extraction. These are spread across the state and involved in various commercial activities. A significant percentage of the Yorubas are found in Funtua town in southern Katsina. They settled there generations ago and have been assimilated into the local community, earning the appellation Yarabawan Funtua (lit. 'the Yorubas of Funtua').

\section{Socio-economic and political context of Katsina State}

Like other states in northern Nigeria, Katsina's economy is mainly agrarian, which means that a large majority of the residents rely on agriculture as a primary means of livelihood. These activities include rain-fed and irrigation cultiva- 
tion, as well as poultry farming, cattle breeding, beekeeping, and forestry. The state government aims to develop its three major dams of Jibia, Sabke, and Zobe for irrigation, but access to fertilizer is still very limited for farmers. According to the International Fund for Agricultural Development (IFAD 2012: 2):

Poverty is widespread in the country and has increased since the late 1990s. Some 70 per cent of Nigerians live on less than US\$1.25 a day. Poverty is especially severe in rural areas, where up to 80 per cent of the population lives below the poverty line, and social services and infrastructure are limited. The country's poor rural women and men depend on agriculture for food and income. About 90 per cent of Nigeria's food is produced by small-scale farmers who cultivate small plots of land and depend on rainfall rather than irrigation systems. The poorest groups eke out a subsistence living but often go short of food, particularly during the pre-harvest period.

Other than agriculture, the second-largest employer in Katsina State is the government. Solid mineral resources are largely underexplored in an oildependent economy, despite the abundance in the region of kaolin, fire clay, ball clay, granite, marble, silica, asbestos, salt, nickel, uranium, lead, iron ore, iron oxide, gold, manganese, cremstones, and precious stones.

\section{Baure LGA: Socio-economic, political and geographical context}

Baure falls under the northern (Daura) senatorial district of Katsina State. It is headquartered at Baure town and was formed from Zango LGA in 1996. The local government has a total area of $707 \mathrm{sq} \mathrm{km}$ and a population of 197,425, according to the 2006 census. It has 12 wards: Baure, Garki, Faski, Maibara, Dankum, Yanduna, Hui, Unguwar Rai, Taramnawa, Yanmaulu, Muduri, and Babban Mutum.

The large majority of Baure's inhabitants are farmers who earn their livelihood through agricultural production, largely crop cultivation alongside the rearing of animals like sheep, goats, and cows. Aside from Yanduna, the wards of the LGA have neither a river nor a dam for commercial irrigation farming. Thus, almost all the farmers engage in subsistence farming of crops such as millet, beans, groundnuts, sesame, and guinea corn. Due to this rural nature, the only major market of the LGA is in Garki, once a week on Mondays. Baure is the most backward, remote, and inaccessible of the five 'invisible' LGAs under review. According to respondents, it recorded several fatal incidents in the years under study (Table 9.1). 
Table 9.1 Violent deaths in Baure LGA (2006-2014)

\begin{tabular}{|c|c|c|c|l|c|}
\hline S/N & Date & Location & Cause & Description & $\begin{array}{c}\text { No. of } \\
\text { deaths }\end{array}$ \\
\hline 1 & June 2011 & Maibawa & $\begin{array}{c}\text { Motor acci- } \\
\text { dent }\end{array}$ & $\begin{array}{l}\text { The accident } \\
\text { was caused by } \\
\text { the numerous } \\
\text { pot-holes on } \\
\text { Baure- Sanda- } \\
\text { mu road. }\end{array}$ & 6 \\
\hline 2 & June 2013 & $\begin{array}{c}\text { Chinai, Babban } \\
\text { Mutum }\end{array}$ & $\begin{array}{c}\text { Motor acci- } \\
\text { dent }\end{array}$ & $\begin{array}{l}\text { The accident } \\
\text { occurred when } \\
\text { a bus driver } \\
\text { tried to over- } \\
\text { take a heavy- } \\
\text { duty vehicle. }\end{array}$ & 7 \\
\hline 3 & Aug 2014 & Garki & $\begin{array}{l}\text { The building } \\
\text { collapse was } \\
\text { caused by a } \\
\text { heavy down- } \\
\text { pour as well as } \\
\text { the lack of a } \\
\text { proper drainage } \\
\text { system in the } \\
\text { village. }\end{array}$ & 5 \\
\hline
\end{tabular}

Source: Fieldwork, November 2014

\section{Kurfi LGA: Socio-economic, political and geographical context}

Kurfi falls under the central (Katsina) senatorial district and is headquartered in Kurfi town. The LGA has a total area of $572 \mathrm{sq} \mathrm{km}$ and a population of 117,581 inhabitants, according to the 2006 census. It was formed from Dutsinma LGA in 1989 and has ten wards: Kurfi A, Kurfi B, Barkiya, Wurma A, Wurma B, Tsauri A, Tsauri B, Rawayau A, Rawayau B, and Birci.

The major economic activity is agricultural production. Inhabitants rely on the Kawara, Barkiya, Wurma, and Tamawa rivers for irrigation farming. In fact, irrigation farming of vegetables such as hot peppers, lettuce, onions, and carrots accounts for about $40 \%$ of the LGA's annual cultivation. For the rain-fed agriculture, people produce crops like maize, guinea corn, beans, groundnuts, and sesame. There are four major weekly markets in the LGA: Wurma on Mondays, Kurfi on Tuesdays, Birci on Thursdays, and Rawayau on Saturdays. According to respondents, the LGA recorded a number of fatal incidents in the years under study (Table 9.2). 
Table 9.2 Violent deaths in Kurfi LGA (2006-2014)

\begin{tabular}{|c|c|c|c|c|c|}
\hline $\mathrm{S} / \mathrm{n}$ & Date & Location & Cause & Description & $\begin{array}{l}\text { No. of } \\
\text { deaths }\end{array}$ \\
\hline 1 & Nov 2008 & $\begin{array}{l}\text { Yakasai village } \\
\text { along the Katsina- } \\
\text { Dutsinma road }\end{array}$ & $\begin{array}{l}\text { Motor acci- } \\
\text { dent }\end{array}$ & $\begin{array}{l}\text { The accident oc- } \\
\text { curred when a } \\
\text { Peugeot J5 } \\
\text { rammed into a } \\
\text { heavy-duty vehi- } \\
\text { cle. While sympa- } \\
\text { thizers were try- } \\
\text { ing to rescue the } \\
\text { victims, a Nissan } \\
\text { Urban crashed } \\
\text { into the crowd. }\end{array}$ & 13 \\
\hline 2 & July 2010 & $\begin{array}{l}\text { Kurfi town, near the } \\
\text { filling station }\end{array}$ & $\begin{array}{l}\text { Motor acci- } \\
\text { dent }\end{array}$ & $\begin{array}{c}\text { A cyclist was hit } \\
\text { and killed by the } \\
\text { driver of a } \\
\text { Volkswagen Golf. }\end{array}$ & 1 \\
\hline 3 & Mar 2013 & Gwanzo village & Execution & $\begin{array}{l}2 \text { alleged armed } \\
\text { robbers were } \\
\text { lynched by local } \\
\text { vigilantes. }\end{array}$ & 2 \\
\hline 4 & June 2013 & $\begin{array}{l}\text { Kurfi town, near } \\
\text { Government Sec- } \\
\text { ondary School }\end{array}$ & $\begin{array}{l}\text { Motor acci- } \\
\text { dent }\end{array}$ & $\begin{array}{l}\text { The driver of a } \\
\text { Volkswagen Golf } \\
\text { wrongly overtook } \\
\text { another vehicle } \\
\text { and rammed into a } \\
\text { Honda Accord. }\end{array}$ & 5 \\
\hline 5 & Oct 2013 & Dalabu Saulawa & Drowning & $\begin{array}{l}\text { The victim was } \\
\text { drowned while } \\
\text { swimming in a } \\
\text { river. }\end{array}$ & 1 \\
\hline 6 & Feb 2014 & $\begin{array}{l}\text { Along the Kurfi- } \\
\text { Batsari road }\end{array}$ & $\begin{array}{l}\text { Motor acci- } \\
\text { dent }\end{array}$ & $\begin{array}{l}\text { The victims died } \\
\text { as a result of a } \\
\text { farmer-herder } \\
\text { clash over water } \\
\text { and grazing land. }\end{array}$ & 7 \\
\hline 7 & Aug 2014 & $\begin{array}{l}\text { Kaukawa, Kurfi } \\
\text { town }\end{array}$ & Drowning & $\begin{array}{l}\text { A boy fell into a } \\
\text { well and was } \\
\text { drowned. }\end{array}$ & 1 \\
\hline 8 & Sept 2014 & $\begin{array}{l}\text { Kurfi town, near } \\
\text { Kurfi General Hos- } \\
\text { pital }\end{array}$ & $\begin{array}{l}\text { Motor acci- } \\
\text { dent }\end{array}$ & $\begin{array}{c}\text { A motorcyclist } \\
\text { was drowned } \\
\text { while swimming } \\
\text { in a river. } \\
\end{array}$ & 1 \\
\hline 9 & Sept 2014 & Wurma village & Assassination & $\begin{array}{l}\text { A local trader was } \\
\text { murdered by a } \\
\text { gang in his house. }\end{array}$ & 1 \\
\hline 10 & Sept 2014 & Yaranda village & $\begin{array}{l}\text { Animal at- } \\
\text { tack }\end{array}$ & $\begin{array}{l}\text { The victim was hit } \\
\text { by his ox while } \\
\text { working on his } \\
\text { farm. }\end{array}$ & 1 \\
\hline
\end{tabular}

Source: Fieldwork, November 2014 


\section{Mani LGA: Socio-economic, political and geographical context}

Mani falls under the northern (Daura) senatorial district of Katsina State. It was one of the first 301 LGAs created in 1976 in Nigeria. Three LGAs (Bindawa, Dutsi, and Mashi) were subsequently formed out of it. It is now headquartered in Mani town and has a total area of $784 \mathrm{sq} \mathrm{km}$ and a population of 176,966, according to the 2006 census. It has 11 wards: Mani, Machika, Kwatta, Jani, Muduru, Tsagem Takusheyi, Bagiwa, Hamceta, Magami, Bujawa Kewayan, and Duwan Makau. Like other LGAs, a large majority of the people rely on agriculture as a means of livelihood. Many engage in intensive irrigation farming of vegetable crops such as tomatoes, hot peppers, and onions. On a daily basis, truckloads of these perishable foods are transported out of Mani to southern Nigeria. The major markets in the LGA are in Mani town, Muduru, and Jani. Mani is the oldest and most developed of the five 'invisible' LGAs. According to respondents, it recorded several fatal incidents in the years under study (Table 9.3).

Table 9.3 Violent deaths in Mani LGA (2006-2014)

\begin{tabular}{|c|c|c|c|c|c|}
\hline $\mathrm{S} / \mathrm{n}$ & Date & Location & Cause & Description & $\begin{array}{l}\text { No. of } \\
\text { deaths }\end{array}$ \\
\hline 1 & June 2011 & Kugado village & Motor accident & $\begin{array}{l}\text { Two vehicles had a } \\
\text { head-on collision. } \\
\text { One of them, a } \\
\text { Peugeot J5, was con- } \\
\text { veying traders return- } \\
\text { ing from a local mar- } \\
\text { ket. }\end{array}$ & 7 \\
\hline 2 & June 2014 & $\begin{array}{c}\text { Gawon Mala } \\
\text { village }\end{array}$ & Motor accident & $\begin{array}{l}\text { The victims included } \\
\text { a mother and her } 2 \\
\text { children in a motor } \\
\text { accident between a } \\
\text { Volkswagen Sharon } \\
\text { SUV and an un- } \\
\text { named vehicle. }\end{array}$ & 5 \\
\hline 3 & Aug 2014 & Magami village & Motor accident & $\begin{array}{l}\text { The victims died in } \\
\text { an accident involving } \\
\text { a Volkswagen Sha- } \\
\text { ron SUV. }\end{array}$ & 3 \\
\hline 4 & Aug 2014 & $\begin{array}{l}\text { Mani town, } \\
\text { Chima River }\end{array}$ & Drowning & $\begin{array}{l}\text { A 26-year old youth } \\
\text { was drowned while } \\
\text { trying to fetch water. }\end{array}$ & 1 \\
\hline 5 & Sept 2014 & $\begin{array}{l}\text { Jani ward, Dalla- } \\
\text { tu River }\end{array}$ & Drowning & $\begin{array}{l}\text { A village head of } \\
\text { Turawa was } \\
\text { drowned. }\end{array}$ & 1 \\
\hline
\end{tabular}

Source: Fieldwork, November 2014 
Matazu LGA: Socio-economic, political and geographical context

Matazu falls under the southern (Funtua) senatorial districts of Katsina State. It is headquartered in Matazu town and was formed from Musawa LGA in 1991. The LGA has a total area of $503 \mathrm{sq} \mathrm{km}$ and a population of 115,325, according to the 2006 census. Matazu has ten wards: Matazu A, Matazu B, Gwarjo, Sayaya, Karaduwa, Kogari, Rinjin Idi, Dissi, and Mazoji A and B.

Farmers produce vegetables such as onions, hot peppers, lettuce, and carrots, thanks to irrigation schemes around the Fandabuwa Dam and three earth dams in Rinjin Idi, Fafu, and Kasharuwa. For the rain-fed agriculture, they produce maize, guinea corn, rice, beans, sesame, soya beans, and cotton. Other than agriculture, the people of Matazu engage in commercial traditional weaving, blacksmithing, and the manufacturing of tools such as hoes. There are three major weekly and bi-weekly markets: Mazoji on Mondays, Matazu on Tuesdays and Fridays, and Karadua on Wednesdays and Saturdays. According to respondents, the LGA recorded a number of fatal incidents in the years under study (Table 9.4).

Ingawa LGA: Socio-economic, political and geographical context

Ingawa falls under the northern (Daura) senatorial district of Katsina State. It is headquartered at Ingawa town. It was formed from Kankia LGA in May 1989. Ingawa has a total area of $892 \mathrm{sq} \mathrm{km}$ and a population of 169,753, according to the 2006 census. It has 11 wards: Ingawa, Kandawa Jobe, Manomawa Kafi, Yayabi Dore, Dara, Daunaka Bakinkwari, Bareruwa Ruruma, Kurfeji Yankaura, Dugul, Yandoma, and Agayawa.

The people of Ingawa rely largely on agriculture as a means of livelihood. The crops cultivated are guinea corn, millet, maize, beans, sesame, cotton, and groundnuts. The inhabitants, particularly those of Agayawa, Yandoma, Dugul, and Dara, are also engaged in commercial traditional weaving. The major weekly markets are in Ingawa on Mondays, Kurfeji on Wednesdays, and Tunas on Sundays. According to respondents, the LGA recorded a number of fatal incidents in the years under study (Table 9.5). 
Table 9.4 Violent deaths in Matazu LGA (2006-2014)

\begin{tabular}{|c|c|c|c|c|c|}
\hline $\mathrm{S} / \mathrm{n}$ & Date & Location & Cause & Description & $\begin{array}{l}\text { No. of } \\
\text { deaths }\end{array}$ \\
\hline 1 & Feb 2010 & $\begin{array}{l}\text { Kogon Maidawa, } \\
\text { Sayawa ward }\end{array}$ & Murder & $\begin{array}{l}\text { A farmer on his way to } \\
\text { his fields was killed } \\
\text { when he came across a } \\
\text { madman carrying a hoe. }\end{array}$ & 1 \\
\hline 2 & Feb 2011 & Salihawa village & Execution & $\begin{array}{l}\text { The alleged ringleader } \\
\text { of a gang engaged in the } \\
\text { theft of goats and sheep } \\
\text { was ambushed and } \\
\text { killed by the communi- } \\
\text { ty's vigilantes. }\end{array}$ & 1 \\
\hline 3 & Sept 2011 & Sayaya village & Drowning & $\begin{array}{l}\text { The victim was in the } \\
\text { business of helping } \\
\text { people cross over the } \\
\text { Sayaya River. One day, } \\
\text { while swimming, he } \\
\text { became exhausted and } \\
\text { was drowned. }\end{array}$ & 1 \\
\hline 4 & Dec 2011 & $\begin{array}{l}\text { Dogon Hawa vil- } \\
\text { lage }\end{array}$ & $\begin{array}{l}\text { Motorcycle } \\
\text { accident }\end{array}$ & $\begin{array}{l}\text { A police officer and a } \\
\text { resident of Karadua } \\
\text { village collided with } \\
\text { one another while riding } \\
\text { on motorcycles. }\end{array}$ & 2 \\
\hline 5 & Feb 2012 & $\begin{array}{l}\text { Near Matazu town- } \\
\text { ship market }\end{array}$ & $\begin{array}{l}\text { Motor ac- } \\
\text { cident }\end{array}$ & $\begin{array}{l}2 \text { motorcyclists were hit } \\
\text { by the driver of a } \\
\text { Volkswagen Golf who } \\
\text { lost control of his car } \\
\text { when its tyre burst. }\end{array}$ & 2 \\
\hline 6 & Aug 2012 & Karadua village & $\begin{array}{l}\text { Motor ac- } \\
\text { cident }\end{array}$ & $\begin{array}{l}\text { The victim was hit by } \\
\text { the driver of a } \\
\text { Volkswagen Golf while } \\
\text { trying to cross the Kafin } \\
\text { Soli-Matazu road. }\end{array}$ & 1 \\
\hline 7 & Nov 2013 & $\begin{array}{l}\text { Matazu town, near } \\
\text { the bridge }\end{array}$ & $\begin{array}{l}\text { Motor ac- } \\
\text { cident }\end{array}$ & $\begin{array}{l}\text { The driver of a Toyota } \\
\text { Starlet hit a motorcycle. } \\
\text { Both the motorcyclist } \\
\text { and the passenger of the } \\
\text { car died. }\end{array}$ & 2 \\
\hline 8 & Aug 2014 & $\begin{array}{l}\text { Sabon Sara village, } \\
\text { Sayaya ward }\end{array}$ & Drowning & $\begin{array}{l}\text { A divorcee who went to } \\
\text { fetch water missed a } \\
\text { step, slipped back into } \\
\text { the river and was } \\
\text { drowned. }\end{array}$ & 1 \\
\hline 9 & Aug 2014 & Nasarawa village & Drowning & $\begin{array}{l}\text { A boy was drowned } \\
\text { while fishing. }\end{array}$ & 1 \\
\hline 10 & Oct 2014 & Rinjin Idi earth dam & Drowning & $\begin{array}{l}4 \text { boys were drowned } \\
\text { while swimming. }\end{array}$ & 4 \\
\hline
\end{tabular}

Source: Fieldwork, November 2014 
Table 9.5 Violent deaths in Ingawa LGA (2006-2014)

\begin{tabular}{|c|c|c|c|c|c|}
\hline $\mathrm{S} / \mathrm{n}$ & Date & Location & Cause & Description & $\begin{array}{l}\text { No. of } \\
\text { deaths }\end{array}$ \\
\hline 1. & June 2007 & $\begin{array}{l}\text { Manomawa Kafi } \\
\text { ward, Gulbin } \\
\text { Gari River }\end{array}$ & Drowning & $\begin{array}{l}\text { A man was } \\
\text { drowned while } \\
\text { trying to recover } \\
\text { his shoes in the } \\
\text { river. }\end{array}$ & 1 \\
\hline 2 & June 2007 & $\begin{array}{l}\text { Ingawa town, } \\
\text { Sabon Gari }\end{array}$ & Fire & $\begin{array}{l}\text { A girl died as a } \\
\text { result of injuries } \\
\text { sustained from a } \\
\text { fire outbreak } \\
\text { caused by a burning } \\
\text { candle. }\end{array}$ & 1 \\
\hline 3 & Feb 2008 & $\begin{array}{l}\text { Ingawa town, } \\
\text { Kofar Yamma }\end{array}$ & Fire & $\begin{array}{l}\text { The victim was } \\
\text { burnt to death after } \\
\text { he set up a fire to } \\
\text { warm his body } \\
\text { during the year's } \\
\text { cold season. }\end{array}$ & 1 \\
\hline 4 & July 2010 & $\begin{array}{l}\text { Ingawa town, } \\
\text { Kofar Yamma }\end{array}$ & Electrocution & $\begin{array}{l}\text { The victim was } \\
\text { electrocuted by an } \\
\text { uninsulated electric } \\
\text { cable he mistakenly } \\
\text { touched while try- } \\
\text { ing to fix the mud } \\
\text { wall of his shop. }\end{array}$ & 1 \\
\hline 5 & Aug 2010 & $\begin{array}{l}\text { Yan Lawal vil- } \\
\text { lage }\end{array}$ & $\begin{array}{l}\text { Cattle graz- } \\
\text { ing }\end{array}$ & $\begin{array}{l}\text { A farmer-herder } \\
\text { clash over water. }\end{array}$ & 7 \\
\hline 6 & Mar 2012 & $\begin{array}{l}\text { Ingawa town, } \\
\text { AUY Petroleum } \\
\text { filling station }\end{array}$ & Explosion & $\begin{array}{l}\text { An attendant died } \\
\text { while trying to fix a } \\
\text { fuel pump, which } \\
\text { ignited an explo- } \\
\text { sion. }\end{array}$ & 1 \\
\hline 7 & Aug 2013 & $\begin{array}{l}\text { Ingawa town, } \\
\text { Kuwait Island }\end{array}$ & Drowning & $\begin{array}{l}\text { A boy was drowned } \\
\text { while swimming in } \\
\text { a river. }\end{array}$ & 1 \\
\hline 8 & May 2014 & Kandawa village & $\begin{array}{c}\text { Motor acci- } \\
\text { dent }\end{array}$ & $\begin{array}{l}\text { The tyre of a } \\
\text { Volkswagen Golf } \\
\text { was shot at by offi- } \\
\text { cials of NDLEA, } \\
\text { who suspected that } \\
\text { passengers were } \\
\text { criminals. }\end{array}$ & 6 \\
\hline 9 & June 2014 & $\begin{array}{l}\text { Kurfeji market, } \\
\text { Ingawa town }\end{array}$ & $\begin{array}{l}\text { Animal At- } \\
\text { tack }\end{array}$ & $\begin{array}{l}\text { The victim was } \\
\text { killed by the bite of } \\
\text { a snake. }\end{array}$ & 1 \\
\hline
\end{tabular}

Source: Fieldwork, November 2014 


\section{Analysis of unreported violent deaths in 'invisible' LGAS}

In Baure, Mani, Matazu, Ingawa, and Kurfi LGAs, the study discovered 37 fatal incidents, resulting in 104 deaths from 2006 to 2014. Kurfi accounted for the highest number of violent deaths $(31.73 \%$ of the total), followed by Ingawa (19.23\%), Baure (17.30\%), Mani (16.34\%), and Matazu (15.38\%). As in many rural regions of Nigeria, fatalities were caused mainly by accidents such as motor crashes, drownings in rivers, electrocutions, fire outbreaks, and animal attacks. Of the 37 incidents, 15 were road accidents, accounting for $65.38 \%$ of the deaths. This finding confirms the argument of Agbonkhese et al. (2013: 90):

Road accidents have become a normal and re-occurring phenomenon in Nigeria. Although both the developed and developing nations of the world have suffered from varying degrees of road accidents, the developing countries clearly dominate with Nigeria having the secondhighest rate of road accidents among 193 ranked countries of the world. Deaths from reckless driving are the third leading cause of death in Nigeria. In 2012, at least 473 persons died from a total of 1,115 vehicular accidents nationwide [...] There could be more unreported cases, and as often happens, some of the injured die without making the statistics.

Second to road accident among the causes of violent deaths in Baure, Mani, Ingawa, Kurfi, and Matazu LGAs was drowning in rivers. Thirteen such incidents resulted in $12.5 \%$ of the fatalities. Other causes of violent deaths were farmer-pastoralist clashes $(6.73 \%)$, building collapses $(4.80 \%)$, assassinations (3.84\%), fire outbreaks $(2.88 \%)$, animal attacks $(1.92 \%)$, explosions $(0.96 \%)$, and electrocutions $(0.96 \%)$.

Surprisingly, political issues were not identified among the causes of fatality, despite Katsina being one of the states affected by the post-2011 election violence. The five LGAs under review have been largely free of the effects of the deadly Boko Haram insurrection. They did not follow the pattern of other regions, where political conflicts constitute the third main cause of fatal violence nationwide (Nigeria Watch 2014: 3). However, the absence of such deaths in the five LGAs was not because there were actually no politically motivated acts of violence, but because these violent activities did not result in any deaths.

\section{Why did incidents go unreported by the national press?}

Two main factors were responsible for the failure of the national press to report fatal incidents in Katsina State: the political economy of the Nigerian media, and the semi-rural nature of the five LGAs. These factors are behind the lack of political and economic interest in these LGAs. Accessibility was not a challenge in the case of Mani, Matazu, Kurfi, and Ingawa, which are easily accessed from the state capital. Only the most rural area, Baure, lacks good roads. 


\section{Ineffective news media coverage as major factor for unreported incidents}

In general, Nigerian journalists are too financially unstable to be able to effectively carry out their duties. Because most of the media cannot sponsor and post reporters to the various states of the Federation, they often employ correspondents with appointment letters and identity cards, leaving them to use whatever means they can to do their job. Such fulltime or freelance journalists have no option but to visit government houses or ministries in order to obtain press releases and some recompense in the form of cash for writing good reports about politicians.

According to Abdullahi Izma Yamadi, the chairman of Katsina State chapter of the Nigeria Union of Journalists (NUJ) (personal communication, 8 October 2014):

There are problems concerning effective coverage by newspapers because most of the reporters are based in the state capital [Katsina] and of course, not only in the state capital but in the corridors of power - at the Government House. When you look at the situation critically, you don't blame the reporters alone: they share the blame with the proprietors of newspapers who just employ these people [the reporters], issue them with identity cards and expect them to go and operate on their own. Of course they [the proprietors] shouldn't expect effective coverage because they didn't provide them with vehicles for easier mobility; they didn't give them all the necessary gadgets - and they are not being paid.

Such reports [unnatural deaths] are reports that don't fetch a penny; no reporter expects to get a penny for reporting such incidents[,] which means they will not have the motivation to cover such incidents in remote rural areas. It is only those press releases that are issued by government agencies that are accompanied with some financial gratification [,] which is why our reporters are always there [in the corridors of power] because that is what they live on. So, I believe there are lapses and ineffectiveness in terms of coverage[,] which is responsible for the lack of reported unnatural deaths in the said 5 LGAs of Katsina State.

In the same vein, S.U. Leman argued (2014: 2):

The working conditions of journalists are in the most cases inadequate. Journalists working, as fulltime and as freelancers, are overall poorly remunerated. They do not enjoy health and safety protection. They are not even provided with the necessary equipment to help them protect themselves in conflicts or civilian unrests. Most media houses are not financially stable or strong and those who have the financial capacity to take safety measures do not want to invest in the safety of journalists and many are not properly trained.

\section{Political economy of news media ownership and control in Nigeria}

Today, the print, broadcast, and Internet media in Nigeria are largely privately owned and controlled. Until its deregulation by the Babangida regime in 1992, the broadcast media in Nigeria was dominated by the government. However, the print media had long before then remained dominated by the private sector. According to Musa and Mohammed (2004: 243): 
In relation to the printed press, notably newspapers, private individuals constitute major owners. In fact, of the 36 states and the Federal Capital Territory, only 14 own newspapers in addition to New Nigerian, Daily Times and Sunday Times owned by the Federal Government. In the case of both Daily Times and Sunday Times, government maintains a $60 \%$ shareholding. The rest of over 42 titles are all owned by private individuals.

At the moment, whereas Daily Times has been sold to a private investor under controversial circumstances, the fate of New Nigerian is deeply uncertain. Some of the 14 state-owned newspapers, such as the Triumph, have been closed down. Thus, the print media in Nigeria today is unarguably owned and controlled by the private sector.

The deregulation of the broadcast media in 1992 also spurred the proliferation of privately owned TV, radio, and cable networks, such as Africa Independent Television (AIT) and Ray Power FM in Lagos, Independent Television (ITV) in Benin City, Channels Television and Vision FM in Abuja, Desmins Independent Television (DITV) and Nagarta Radio in Kaduna, and Freedom Radio and Rahama Radio in Kano. According to Ariye (2010):

For several decades in Nigeria government could not muster courage to allow individuals to own electronic media. The fear expressed then was that radio and television as potent forces for mass mobilization should not be insensitively allowed to slip into the hands of private individuals. But by 1992 President Babangida announced that one of the legacies he would want to leave behind was the privatization of the electronic media. He then went on to establish the National Broadcasting Commission (NBC), charging it to ensure that private radio and television licenses are issued before the end of his administration.

However, it is still difficult for journalists to effectively cover the length and breadth of the country's vast land mass. Critically looking at the private media in Nigeria, one can clearly see that, historically, very few owners are apolitical. Almost all of them are either biased or card-carrying members of one political party or another. Thus, they are not neutral and do not serve the interests of the masses. Notable examples of media owners who are also politicians are APC's founding leader Bola Ahmed Tinubu (Nation), PDP stalwart Raymond Dokpesi (AIT/Raypower), APC presidential aspirant Sam Nda-Isaiah (Leadership), and former PDP Abia State governor Orji Uzor Kalu (The Sun).

Others who do not show any sympathy for a political party may be promoting a regional or ethnic agenda. They see their news media outfits as platforms to launch themselves into the political arena and win elected positions in Nigeria. Musa and Mohammed (2004: 244) also share this belief:

As usual of Nigerian politicians, some of them found media organizations to boost their standing in the polity preparatory to their active participation in partisan politics. At least two instances may be recalled here. Chief Mike Ajaegbo, who founded Minaj cable television in 1995, later became a stalwart of PDP and successfully contested election as senator of the Federal Republic. The other is Mr James Ibori, who established the Diet daily and Sunday newspapers, joined PDP and successfully contested elections to become Governor of Delta 
State. Until they founded their respective media, both Ajaegbo and Ibori were hardly reckoned with as politicians either at national, state or local levels.

Thus, the vision of the majority of the Nigerian media is rarely about the masses. Instead, newspapers, radio, and TV stations are a tool for the actualization of the personal ambitions, interests, and agendas of their owners. This explains why the welfare of reporters and their ability to cover remote rural areas are not a primary concern.

\section{Conclusion}

This research investigated the unreported cases of violent deaths in five LGAs of Katsina State: Baure, Mani, Ingawa, Kurfi, and Matazu. It showed that the absence of records of fatalities was a result of shortcomings in the system of datagathering by the media. The political economy of the ownership and control of the news media in Nigeria explains the ineffectiveness of the coverage of such rural areas. Historically, the private media has never been pro-masses but rather pro-establishment. Hence, unreported cases of violent deaths in rural Nigeria will continue to occur.

\section{References}

Agbonkhese, O., G.L. Yisa, E.G. Agbonkhese, D.O. AKanbi, E.O. AKa \& E.B. Mondigha (2013), Road Traffic Accidents in Nigeria: Causes and Preventive Measures. Civil and Environmental Research 3(13).

Agomuo, Z. (2013), Rethinking Nigeria's Over-Dependence on Oil. Business Day, June 17.

ALLI, Y. (2014), Boko Haram Has Killed over 10,000 - NSA. The Nation, October 14.

ARIYE, E.C. (2010), The Impact of Private Broadcasting in Nigeria. Medwell Journals 7(6): 415-423.

Ayodele, O.S., A. SABASTINE \& U.P. NNADOZIE (2013), Economic Diversification in Nigeria: Any Role for Solid Mineral Development. Mediterranean Journal of Social Science 4(6). http://www.mcser.org/journal/index.php/mjss/article/view/351/367.

IFAD (2012), Enabling Poor Rural People to Overcome Poverty in Nigeria. www.ifad.org/operations/projects/regions/pa/factsheets/ng.pdf.

KATSINA LOCAL GOVERNMENT WEBSITE. http://katsinastate-lgac.com/history.html.

KrUG, E.G., T.T. DAHLBERG, J.A. MERCy, A.B. Zwi \& R. LoZANO, eds, (2002), World Report on Violence and Health. Geneva: World Health Organization.

LEMAN, S.U. (2014), Thoughts on Nigeria Media and Ethical Challenges, presented at a workshop organized by Konrad Adenauer Foundation and German Embassy. http://www.kas.de/wf/doc/kas_15725-1442-1-30.pdf?150428165044.

Musa, M. \& J. Mohammed (2004), The Political Economy of the Media in Nigeria. In: P.N. Thomas, \& Z. Nain, eds, Who Owns the Media: Global Trends and Local Resistance. United Kingdom: World Association of Christian Communications, pp. 227-247. 
National Bureau of Statistics (2012), Agriculture.

http://www.nigerianstat.gov.ng/sectorstat/sectors/Agriculture.

NigERIA WATCH: Fourth Report on Violence in Nigeria (2006-2014), Ibadan: IFRA-Nigeria.

OlaJide, OT., B.H. AKINLABI \& A.A. TIJJANI (2012), Agriculture Resource and Economic

Growth in Nigeria. European Scientific Journal 8(22).

WHO (2002), World Report on Violence and Health. Geneva: WHO. 


\title{
A study of violence-related deaths in Gudu, Gwadabawa and Illela LGAs of Sokoto State, and Sakaba LGA of Kebbi State (2006-2014)
}

\author{
Arshad Munir \& Akinola Ejodame Olojo
}

\begin{abstract}
This paper highlights the outcome of a study on fatal incidents in four LGAs of north-western Nigeria: Gwadabawa, Gudu, and Ilella LGAs in Sokoto State, and Sakaba LGA in Kebbi State. Data obtained from 1,083 questionnaires revealed that, since 2006, the year 2011 had the highest number of fatalities. Between 2006 and 2014, Gudu LGA recorded the highest number of fatalities and violent incidents, while Sakaba LGA had the lowest. For the period under review, the most frequent cause of fatal incidents was cattle grazing, followed by political clashes. Religion, which is often perceived as a major factor of conflict, contributed quite insignificantly to the overall level of violence in the four LGAs, with just a few incidents involving the Yan Shi'a, the Tijaniyya Sufi brotherhood, and the Yan Izala movement. Finally, the study demonstrates that, just as in the urban centres of Sokoto and Kebbi, there are many fatal incidents in rural areas - yet these are unreported. Some explanations for this omission are discussed in relation to poor road infrastructure.
\end{abstract}

\section{Introduction and methodology}

One of the primary concerns of the 'invisible' violence project of Nigeria Watch is to analyse particular LGAs where fatal incidents appear to have fallen outside the radar of press coverage. The issue is to discover whether this omission results from a dearth of media reports or from an authentic absence of lethal violence. Bearing this framework in mind, the current study investigates 'invisible' fatal incidents in Gudu, Gwadabawa, and Illela LGAs in Sokoto State, and Sakaba LGA in neighbouring Kebbi State.

Northern Nigeria now offers the general impression of an entire region in crisis. However, some analytical nuance is required to distinguish areas that are in- 
deed rife with violence from those largely undisturbed. Thus the north-western geo-political zone of Nigeria includes a mix of states such as Kano and Kaduna, characterized by occasional-to-recurrent crises, and Zamfara, Sokoto, and Kebbi, which have relatively low-intensity violence. To fine-tune our focus on selected LGAs in Sokoto and Kebbi, two main questions must be asked. First, what is the general character of fatal incidents in Gudu, Gwadabawa, Illela, and Sakaba? Second, what factors help to make sense of this gap in the recognition and reporting of violence in the affected LGAs?

The paper responds to these questions by starting with a brief description of the local socio-political and socio-economic context. With empirical content, it then discusses the nature of lethal violence in the selected LGAs. In the next section, it sheds light on the factors identified as responsible for the shortcomings of reports and records of fatal incidents, while the final part of the paper concludes with remarks on the overall research findings.

In regard to methodology, a total of 1,200 questionnaires were circulated across a broad spectrum of residents in the four LGAs. Although not all respondents completed every aspect of the questionnaire, a total of 1,083 returned sufficient data to generate a gender matrix complete with figures and percentages in relation to each of the four LGAs. However, to employ further rigour in the distillation of the received data, questionnaires not containing key indices for analyses (causes and descriptions of violent incidents, numbers of fatalities) were separated to generate another set of tables in relation to the four LGAs. Therefore, the total number of respondents recorded in the gender matrix (Table 10.1) does not necessarily match the total number of respondents recorded in Tables 10.2, 10.3, 10.4 and 10.5 .

A challenge encountered in the study was in relation to questionnaires that appeared to duplicate the same fatal incident, year of event, affected community, and cause of violence. While such questionnaires presented nearly the same set of data, they tended to contain different figures for the number of fatalities. Therefore, such cases were addressed by taking the average of the fatalities recorded, since all other variables remained constant. Furthermore, it is possible that there were instances where certain questionnaires presented different causes for a single violent incident. It should also be taken into account that the limitations of human memory on the part of most respondents limited the generation of data in regard to dates of violent occurrences. Consequently, the tables presented for each of the four LGAs reflect only the years that incidents took place, not the days and months. In all, this study establishes that the overarching pattern of lethal violence in Sokoto and Kebbi has been generally underestimated in terms of its occurrence rate in rural areas and of the frequency of fatalities. 


\section{Gudu, Gwadabawa, Illela and Sakaba: A bird's-eye view}

Gudu, Gwadabawa, and Illela are among the 23 LGAs in Sokoto State. Population distribution figures published by the National Population Commission (NPC) suggest that the total population of Gudu, Gwadabawa, and Illela are $95,400,231,569$, and 150,133 , respectively. ${ }^{1}$ For reasons that may help to explain why violent incidents have received minimal attention from the media, it is important to note that Gudu LGA is situated in a remote part of Sokoto State and, in fact, shares a border with the Republic of Niger. Its capital is a town called Balle, but there are a number of other localities. Similar to Gudu, Illela LGA is also situated far from the geographical centre of Sokoto and shares a border with the Republic of Niger. Among the three LGAs, Gwadabawa is the largest in terms of population size, akin to Sokoto North for instance. However, demographic features do not explain why some LGAs receive little attention as far as violent incidents are concerned.

Gwadabawa is noted to have played an important role in the historical buildup of the Sokoto caliphate. This fact is acknowledged by Hugh Johnston, who further explains how certain parts of present-day northern Nigeria such as Gwadabawa were geographically compact and, in fact, not dissimilar from English counties. ${ }^{2}$ Gudu, Gwadabawa, and Illela - and by extension the entire northwestern zone of which Sokoto and Kebbi are a part - owe much of their relative order and peaceful milieu to the influence of history and particularly that phase associated with the legacy of the $1804 \mathrm{jihad}$. Although not the main focus of this section, there is an important point to be made regarding how the jihad led by Sheikh Uthman dan Fodio occasioned not only an Islamic and scholastic revolution but also the bequeathing of a profound socio-political structure and administrative organization of the society which we now know as contemporary Sokoto State. What appears to be the peaceful character of Sokoto and Kebbi is even more significant in light of the ongoing Boko Haram insurgency, to which other northern states such as Borno and Yobe bear witness. It is therefore amidst this apparent atmosphere of relative peace and stability in Sokoto and Kebbi that the challenge of addressing the phenomenon of unreported violent incidents also gains importance.

Like most of the other LGAs in Sokoto State, Gudu, Gwadabawa, and Illela have their economies based on agriculture and particularly subsistence farming. Several crops are cultivated, but the main ones in these LGAs include millet, maize, guinea corn, and beans/cowpeas. Cattle grazing remains a common prac-

\footnotetext{
National Population Commission (2010), 2006 Population and Housing Census: Priority Table Volume IV. http://www.population.gov.ng/index.php/publications/141-population-distribution-by-ageand-sex-2006-census-priority-tables-vol-4.

2 Johnston, H. (1967), The Fulani Empire of Sokoto. Oxford: Oxford University Press.
} 
tice, which explains why the data in this study underscores how this economic activity is fused with the overall portrait of violent incidents. Weaving, dyeing, and tanning constitute a main focus of local industries; and although attempts have been made by a number of state government authorities to stimulate mechanized agriculture, these LGAs - and indeed Sokoto State - still exhibit a high level of both relative and absolute poverty in comparison with other states. ${ }^{3}$

In terms of religion, Gudu, Gwadabawa, and Illela, in common with other LGAs in Sokoto State, are over $90 \%$ Muslim, and the predominant language spoken is Hausa (with Fulfulde spoken to a lesser extent). The political landscape in Gudu, Gwadabawa, and Illela has maintained quite a competitive character over the years and especially during the period (2006-2014) examined in this study. A considerable number of the violent incidents identified in the aforementioned LGAs are attributable to the evolution and contestation involving political parties, such as the People's Democratic Party (PDP) and the four defunct parties that later merged to form the All Progressives Congress (APC). These four defunct parties, which were once active within the aforesaid LGAs, comprise the Congress for Progressive Change (CPC), the Action Congress of Nigeria (ACN), the All Nigeria People's Party (ANPP), and a faction of the All Progressives Grand Alliance (APGA). Another party involved in some of the violent incidents was the Democratic People's Party (DPP).

The socio-political and economic dynamics of Sakaba LGA in Kebbi State are largely associated with the larger historical trajectory of Sokoto State. This of course can be understood by the fact that Kebbi was carved out of Sokoto in August 1991. Of 21 LGAs, Sakaba is among the three least populated LGAs in Kebbi State, with a population of 91,728. The other two smaller LGAs are Kalgo (with a population of 84,928$)$ and Aleiro $(67,078) .{ }^{4}$ Its comparably low population contributes to the perception of Sakaba by the media as unimportant, and its geographical location within Kebbi places it at an extreme corner of the state, sharing borders with neighbouring Niger. Most people from Sakaba practise Islam and are largely Hausa-speaking. There are also some inhabitants who adhere to Christianity or traditional religious beliefs. For instance, traces of traditional religious worship can still be found among the Cicipu-speaking people, who are ethnically referred to as the Acipu, in the part of Sakaba that shares a border with Kontagora LGA in Niger. Subsistence farming and livestock production are widely practised in the area. However, the remote communities of the LGA are severely challenged by problems of accessibility, especially by car during the rainy season. Absent road infrastructure hampers the possibility for farmers to

3 National Bureau of Statistics (2012), Nigeria Poverty Profile 2010 Report. http://www.tucrivers.org/tucpublications/Nigeria\%20Poverty\%20Profile\%202010.pdf

4 National Population Commission (2010), 2006 Population and Housing Census: Priority Table Volume IV. 
market their harvests outside Sakaba and explains the tendency for violent incidents to go unnoticed by the media and local authorities.

Table 10.1 Demographics of respondents in Gudu, Gwadabawa, Illela, and Sakaba LGAs

\begin{tabular}{lcccc}
\hline LGA & Male & Female & Total & $\begin{array}{c}\text { \% Male / } \\
\text { Female }\end{array}$ \\
\hline Gudu & 234 & 47 & 281 & $83.27 / 16.73$ \\
Gwadabawa & 217 & 87 & 304 & $71.38 / 26.62$ \\
Illela & 155 & 90 & 245 & $63.27 / 36.73$ \\
Sakaba & 149 & 104 & 253 & $58.89 / 41.11$ \\
\hline
\end{tabular}

Source: Fieldwork, August-September 2014

As noted in the introductory section, Table 10.1 is based on the data from questionnaires in which respondents indicated their gender status in the respective LGAs. While it may not provide the complete gender portrayal of every respondent, it does provide an impression suggestive of the gender ratio in each of the LGAs. Thus, if the suggested gender ratio is anything to go by, the most striking feature is that there is a much lower response rate from females than from males in all the LGAs. However, the lower feedback rate from females is not in any way a consequence of fewer women in the LGAs. In fact, according to official statistics, Illela LGA, for instance, has a slightly higher number of females $(75,184)$ than males $(74,949)$. Such a skewed outcome can be understood in light of the socio-cultural dynamics which persist in obscuring the 'visibility' and representation of women in these communities. Furthermore, the marked religious context of these communities also shapes the interaction of males and females in certain public spaces. This factor no doubt exerted some influence on the willingness of certain women to respond and render numerically representative feedback to the questionnaires. 
Violent incidents in Gudu, Gwadabawa, Illela, and Sakaba (June 2006-May 2014)

Table 10.2 Violent incidents in Gudu LGA (June 2006-May 2014)

\begin{tabular}{|c|c|c|c|c|c|}
\hline $\mathrm{S} / \mathrm{N}$ & Date & Community & Cause & Description & $\begin{array}{l}\text { No. of } \\
\text { deaths }\end{array}$ \\
\hline 1 & 2006 & Balle & Cattle grazing & Fulani vs. Balle farmers & 3 \\
\hline 2 & 2006 & Kurdula & Cattle grazing & Fulani vs. farmers & 2 \\
\hline 3 & 2006 & Gwazange & Car accident & Due to bad roads & 7 \\
\hline 4 & 2007 & Balle & Political crisis & PDP vs. DPP supporters & 3 \\
\hline 5 & 2007 & Balle & Political crisis & $\begin{array}{l}\text { DPP vs. PDP supporters } \\
\text { during rally }\end{array}$ & 5 \\
\hline 6 & 2007 & Kurdula & Political crisis & $\begin{array}{l}\text { DPP vs. PDP supporters } \\
\text { during rally }\end{array}$ & 5 \\
\hline 7 & 2007 & Gwazange & Political crisis & ACN vs. PDP supporters & 2 \\
\hline 8 & 2007 & Gwazange & Political crisis & ANPP vs. DPP supporters & 1 \\
\hline 9 & 2007 & Dayeji & Political crisis & ANPP vs. DPP supporters & 8 \\
\hline 10 & 2007 & Tunga & Political crisis & $\begin{array}{l}\text { Former governor's } \\
\text { (Bafarawa) supporters vs. } \\
\text { incumbent Sokoto State } \\
\text { governor's (Wammako) } \\
\text { supporters }\end{array}$ & 7 \\
\hline 11 & 2007 & Bachaka & Political crisis & ANPP vs. DPP supporters & 2 \\
\hline 12 & 2007 & Karfe & Political crisis & $\begin{array}{l}\text { Internal fighting within } \\
\text { DPP }\end{array}$ & 1 \\
\hline 13 & 2007 & Kuturure & Political crisis & ANPP vs. DPP supporters & 2 \\
\hline 14 & 2007 & Gurdam & Political crisis & ANPP vs. ACN supporters & 6 \\
\hline 15 & 2007 & Gwazange & Crime & $\begin{array}{l}\text { Neighbouring villages } \\
\text { fought each other }\end{array}$ & 1 \\
\hline 16 & 2007 & Bangi & Cattle grazing & Fulani vs. farmers & 1 \\
\hline 17 & 2007 & Kurdula & Crime & $\begin{array}{l}\text { Family feud involving } \\
\text { Hussaini and Amina }\end{array}$ & 2 \\
\hline 18 & 2007 & Balle & Crime & $\begin{array}{l}\text { A man against another man } \\
\text { over marriage matters }\end{array}$ & 1 \\
\hline 19 & 2007 & Bachaka & Car accident & Due to over-speeding & 8 \\
\hline 20 & 2007 & Filisko & Crime & $\begin{array}{l}\text { Kanwuri vs. Sabon Gari } \\
\text { communities }\end{array}$ & 2 \\
\hline 21 & 2008 & Balle & Political crisis & ANPP vs. DPP supporters & 1 \\
\hline 22 & 2008 & Bachaka & Political crisis & DPP vs. PDP supporters & 1 \\
\hline 23 & 2008 & Chalasko & Political crisis & ANPP vs. DPP supporters & 2 \\
\hline 24 & 2008 & Dayeji & Cattle grazing & $\begin{array}{l}\text { Fulani and farmers fought } \\
\text { over allegation of stolen } \\
\text { cattle }\end{array}$ & 4 \\
\hline 25 & 2008 & Gwazange & Cattle grazing & Fulani vs. farmers & 2 \\
\hline 26 & 2008 & Bachaka & Cattle grazing & Fulani vs. farmers & 1 \\
\hline
\end{tabular}


Table 10.2 Violent incidents in Gudu LGA (June 2006-May 2014), continued

\begin{tabular}{|c|c|c|c|c|c|}
\hline 27 & 2008 & Dayeji & Cattle grazing & Fulani vs. farmers & 2 \\
\hline 28 & 2008 & Bachaka & Crime & Family dispute & 1 \\
\hline 29 & 2008 & Kurdula & Car accident & No description & 8 \\
\hline 30 & 2008 & Gwazange & Car accident & No description & 2 \\
\hline 31 & 2009 & Kurdula & Political crisis & ACN vs. PDP supporters & 1 \\
\hline 32 & 2009 & Tunga & Cattle grazing & Fulani vs. Tunga farmers & 3 \\
\hline 33 & 2009 & Rafin Kubu & Cattle grazing & Fulani vs. farmers & 2 \\
\hline 34 & 2009 & Karfe & Cattle grazing & Fulani vs. farmers & 6 \\
\hline 35 & 2009 & Bachaka & Cattle grazing & Fulani vs. farmers & 2 \\
\hline 36 & 2009 & Kurdula & Cattle grazing & Fulani vs. farmers & 1 \\
\hline 37 & 2009 & Tunga & Crime & $\begin{array}{l}\text { Associated with community } \\
\text { issues }\end{array}$ & 1 \\
\hline 38 & 2009 & Bachaka & Market issue & $\begin{array}{l}\text { Family feud over economic } \\
\text { issues }\end{array}$ & 1 \\
\hline 39 & 2009 & Balle & Crime & $\begin{array}{l}\text { One man with his wife } \\
\text { against another man }\end{array}$ & 1 \\
\hline 40 & 2010 & Gwazange & Political crisis & PDP vs. DPP supporters & 1 \\
\hline 41 & 2010 & Rafin Kubu & Political crisis & PDP vs. DPP supporters & 1 \\
\hline 42 & 2010 & Filasko & Political crisis & CPC vs. PDP supporters & 2 \\
\hline 43 & 2010 & Gudu Town & Political crisis & PDP vs. DPP supporters & 3 \\
\hline 44 & 2010 & Balle & Political crisis & CPC vs. DPP supporters & 2 \\
\hline 45 & 2010 & Gurdam & Political crisis & $\begin{array}{l}\text { DPP vs. PDP supporters } \\
\text { during rally }\end{array}$ & 1 \\
\hline 46 & 2010 & Tunga & Cattle grazing & Fulani vs. Tunga farmers & 3 \\
\hline 47 & 2010 & Bachaka & Cattle grazing & Fulani vs. farmers & 3 \\
\hline 48 & 2010 & Kurdula & Cattle grazing & $\begin{array}{l}\text { Fulani vs. Hausa communi- } \\
\text { ty }\end{array}$ & 3 \\
\hline 49 & 2010 & Kurdula & Crime & $\begin{array}{l}\text { Violence erupted between a } \\
\text { couple leading to death of } \\
\text { the man }\end{array}$ & 1 \\
\hline 50 & 2010 & Tunga & Cattle grazing & Fulani vs. Tunga farmers & 1 \\
\hline 51 & 2010 & Bachaka & Cattle grazing & Fulani vs. farmers & 3 \\
\hline 52 & 2010 & Gurdam & Cattle grazing & Fulani vs. farmers & 2 \\
\hline 53 & 2010 & Gwazange & Crime & Family feud & 1 \\
\hline 54 & 2010 & Dorasa Area & Crime & $\begin{array}{l}\text { Community vs. community } \\
\text { over economic issues }\end{array}$ & 1 \\
\hline 55 & 2010 & Gwazange & Crime & $\begin{array}{l}\text { Involvement of male and } \\
\text { female youths }\end{array}$ & 2 \\
\hline 56 & 2010 & Bachaka & Car accident & Due to bad roads & 2 \\
\hline 57 & 2010 & Yakka & Crime & Parent-to-parent violence & 2 \\
\hline 58 & 2011 & Bachaka & Political crisis & $\begin{array}{l}\text { PDP vs. DPP supporters } \\
\text { during electoral campaign }\end{array}$ & 2 \\
\hline 59 & 2011 & Bachaka & Political crisis & PDP vs. ACN supporters & 1 \\
\hline 60 & 2011 & Gudu & Political crisis & DPP vs. PDP supporters & 5 \\
\hline 61 & 2011 & Balle & Political crisis & $\begin{array}{l}\text { DPP vs. PDP supporters } \\
\text { during rally }\end{array}$ & 2 \\
\hline
\end{tabular}


Table 10.2 Violent incidents in Gudu LGA (June 2006-May 2014), continued

\begin{tabular}{|c|c|c|c|c|c|}
\hline 62 & 2011 & Balle & Crime & $\begin{array}{l}\text { Villagers vs. hooligans in } \\
\text { town }\end{array}$ & 1 \\
\hline 63 & 2011 & Kokotau & Political crisis & PDP vs. CPC supporters & 2 \\
\hline 64 & 2011 & Balle & $\begin{array}{l}\text { Natural disas- } \\
\text { ter }\end{array}$ & Flooding crisis & 1 \\
\hline 65 & 2011 & Yakka & Political crisis & PDP vs. ANPP supporters & 2 \\
\hline 66 & 2011 & Salawa & Political crisis & PDP vs. CPC supporters & 2 \\
\hline 67 & 2011 & $\begin{array}{c}\text { Salawa, Gudun } \\
\text { Buki }\end{array}$ & Fire & $\begin{array}{l}\text { Fire in the houses of Dan } \\
\text { Tunau and Suleiman }\end{array}$ & 4 \\
\hline 68 & 2011 & $\begin{array}{l}\text { Salawa, Gudun } \\
\text { Buki } \\
\end{array}$ & $\begin{array}{l}\text { Natural disas- } \\
\text { ter }\end{array}$ & No description & 5 \\
\hline 69 & 2011 & Shatoka, Zabarma & $\begin{array}{l}\text { Natural disas- } \\
\text { ter }\end{array}$ & No description & 2 \\
\hline 70 & 2011 & Karfen Chana & Political crisis & CPC vs. APGA supporters & 2 \\
\hline 71 & 2011 & Gwazange & Political crisis & $\begin{array}{l}\text { DPP vs. PDP supporters } \\
\text { during rally }\end{array}$ & 2 \\
\hline 72 & 2011 & Gwazange & Market issue & $\begin{array}{l}\text { Two persons clashed over } \\
\text { ownership of a bag of rice } \\
\text { in a market place }\end{array}$ & 2 \\
\hline 73 & 2011 & Tunga & Political crisis & $\begin{array}{l}\text { DPP vs. PDP supporters } \\
\text { during rally }\end{array}$ & 2 \\
\hline 74 & 2011 & Filasko & Political crisis & PDP vs. DPP supporters & 2 \\
\hline 75 & 2011 & Filasko & Cattle grazing & Fulani vs. farmers & 3 \\
\hline 76 & 2011 & Filasko & Market issue & Business-related conflict & 2 \\
\hline 77 & 2011 & Kurdula & Political crisis & $\begin{array}{l}\text { DPP vs. PDP supporters } \\
\text { during rally }\end{array}$ & 3 \\
\hline 78 & 2011 & Rafin Kubu & Political crisis & $\begin{array}{l}\text { ANPP vs. DPP supporters } \\
\text { during rally }\end{array}$ & 1 \\
\hline 79 & 2011 & Dayeji & Political crisis & $\begin{array}{l}\text { PDP vs. DPP supporters } \\
\text { during voting campaign }\end{array}$ & 1 \\
\hline 80 & 2011 & Gurdam & Crime & Community vs. community & 1 \\
\hline 81 & 2011 & Karfe & Crime & Community vs. community & 2 \\
\hline 82 & 2011 & Karfe & Political crisis & $\begin{array}{l}\text { PDP vs. DPP supporters } \\
\text { during voting campaign }\end{array}$ & 33 \\
\hline 83 & 2011 & Boto & Cattle grazing & Fulani vs. farmers & 2 \\
\hline 84 & 2011 & Karfen Sarki & Cattle grazing & Fulani vs. farmers & 1 \\
\hline 85 & 2011 & Karfen Sarki & Crime & $\begin{array}{l}\text { Football clash: Gudu United } \\
\text { vs. Karfen Sarki Stars }\end{array}$ & 2 \\
\hline 86 & 2011 & Tunga & Crime & Rapist beaten to death & 1 \\
\hline 87 & 2011 & Karfen Chana & $\begin{array}{l}\text { Religious } \\
\text { crisis }\end{array}$ & Yan Izala vs. Yan Shi’a & 1 \\
\hline 88 & 2011 & Shiyar Yamma & Cattle grazing & Fulani vs. farmers & 1 \\
\hline 89 & 2012 & Gudun Buki & Political crisis & PDP vs. ANPP supporters & 2 \\
\hline 90 & 2012 & Salawa & Crime & $\begin{array}{l}\text { Conflict between husband } \\
\text { and wife }\end{array}$ & 3 \\
\hline 91 & 2012 & Salawa & Cattle grazing & Fulani vs. farmers & 1 \\
\hline
\end{tabular}


Table 10.2 Violent incidents in Gudu LGA (June 2006-May 2014), continued

\begin{tabular}{|c|c|c|c|c|c|}
\hline 92 & 2012 & Boto & Political crisis & CPC vs. ANPP supporters & 2 \\
\hline 93 & 2012 & Gozange & Political crisis & PDP vs. CPC supporters & 2 \\
\hline 94 & 2012 & Bachaka & Political crisis & ANPP vs. PDP supporters & 3 \\
\hline 95 & 2012 & Bachaka & Crime & $\begin{array}{l}\text { Tunga vs. Bachaka commu- } \\
\text { nity clash }\end{array}$ & 2 \\
\hline 96 & 2012 & Bachaka & Market issue & Muslim vs. Muslim & 2 \\
\hline 97 & 2012 & Bachala & Political crisis & PDP vs. ACN supporters & 31 \\
\hline 98 & 2012 & Bangi & Cattle grazing & Fulani vs. Bangi farmers & 1 \\
\hline 99 & 2012 & Balle & Car accident & $\begin{array}{l}\text { Bad roads and over- } \\
\text { speeding }\end{array}$ & 2 \\
\hline 100 & 2012 & Makuya & Fire & No description & 1 \\
\hline 101 & 2012 & Kokotau & Fire & $\begin{array}{l}\text { Explosion in Makepa area } \\
\text { in Kokotau }\end{array}$ & 3 \\
\hline 102 & 2012 & Yakka & $\begin{array}{l}\text { Religious } \\
\text { crisis }\end{array}$ & Muslims vs. Christians & 9 \\
\hline 103 & 2013 & Balle & Political crisis & PDP vs. APC supporters & 1 \\
\hline 104 & 2013 & Balle & Cattle grazing & Fulani vs. farmers & 1 \\
\hline 105 & 2013 & Gwazange & Cattle grazing & Fulani vs. farmers & 2 \\
\hline 106 & 2013 & Bachaka & Cattle grazing & Fulani vs. farmers & 2 \\
\hline 107 & 2013 & Bachala & Political crisis & APC vs. PDP supporters & 5 \\
\hline 108 & 2013 & Yar Bakwai & $\begin{array}{l}\text { Religious } \\
\text { crisis }\end{array}$ & Yan Shi'a vs. Sunni & 2 \\
\hline 109 & 2013 & Boto & $\begin{array}{l}\text { Religious } \\
\text { crisis }\end{array}$ & Tijaniyya vs. Yan Izala & 6 \\
\hline 110 & 2013 & Karfen Sarki & Crime & $\begin{array}{l}\text { Bakin Gari vs. Chikin Gari } \\
\text { communities }\end{array}$ & 2 \\
\hline 111 & 2013 & Chalasko & Crime & $\begin{array}{l}\text { House of Dan Mamman vs. } \\
\text { family of Saraki }\end{array}$ & 3 \\
\hline 112 & 2013 & Chalasko & Market issue & Buyer vs. seller & 2 \\
\hline 113 & 2013 & Filasko & Crime & Conflict over a girlfriend & 1 \\
\hline 114 & 2013 & Kurdula & Cattle grazing & $\begin{array}{l}\text { Hausa-Fulani clash for } \\
\text { three days before police } \\
\text { intervention }\end{array}$ & 2 \\
\hline 115 & 2013 & Huda & $\begin{array}{l}\text { Natural disas- } \\
\text { ter }\end{array}$ & Windstorm & 1 \\
\hline 116 & 2013 & Bangi & $\begin{array}{c}\text { Natural disas- } \\
\text { ter } \\
\end{array}$ & $\begin{array}{l}\text { Water erosion between } \\
\text { Kokotau and Bangi towns }\end{array}$ & 3 \\
\hline 117 & 2014 & Karfe & Political crisis & APC vs. PDP supporters & 2 \\
\hline 118 & 2014 & Karfe & Cattle grazing & $\begin{array}{l}\text { Fulani vs. farmers, over } \\
\text { missing cow }\end{array}$ & 7 \\
\hline 119 & 2014 & Balle & Cattle grazing & Fulani vs. farmers & 1 \\
\hline 120 & 2014 & Balle & Political crisis & APC vs. PDP supporters & 6 \\
\hline 121 & 2014 & Balle & Car accident & $\begin{array}{l}\text { Collision between two mo- } \\
\text { torcycle riders, leaving one } \\
\text { dead }\end{array}$ & 1 \\
\hline 122 & 2014 & Balle & Car accident & Due to bad roads & 2 \\
\hline
\end{tabular}


Table 10.2 Violent incidents in Gudu LGA (June 2006-May 2014), continued

\begin{tabular}{|c|c|c|c|l|c|}
\hline 123 & 2014 & Balle & $\begin{array}{c}\text { Natural disas- } \\
\text { ter }\end{array}$ & Heavy rainfall and floods & 1 \\
\hline 124 & 2014 & Tunga & Cattle grazing & $\begin{array}{l}\text { Fulani vs. farmers, over } \\
\text { allegation of stolen cattle }\end{array}$ & 1 \\
\hline 125 & 2014 & Kurdula & Cattle grazing & Fulani vs. farmers & 2 \\
\hline 126 & 2014 & Kurdula & Car accident & Due to bad roads & 2 \\
\hline 127 & 2014 & Garin Gabas & Crime & $\begin{array}{l}\text { Armed gang invaded com- } \\
\text { munity }\end{array}$ & 1 \\
\hline 128 & 2014 & Makuya & Car accident & $\begin{array}{l}\text { Due to over-speeding and } \\
\text { bad roads }\end{array}$ & 2 \\
\hline 129 & 2014 & Shetallo & $\begin{array}{c}\text { Religious } \\
\text { crisis }\end{array}$ & Tijaniyya vs. Yan Izala & 2 \\
\hline 130 & 2014 & Bachaka & Cattle grazing & Fulani vs. farmers & 1 \\
\hline 131 & 2014 & Bachaka & Car accident & Due to bad roads & 1 \\
\hline
\end{tabular}

Source: Fieldwork, August-September 2014

Based on the data presented in Table 10.2, there were at least 131 violent incidents in Gudu LGA between 2006 and 2014, resulting in a total number of 367 fatalities. These unreported incidents affected at least 39 different wards and communities within Gudu. The top three causes of violence were political crisis (45 incidents), cattle grazing (33), and crime (23). The three least frequent causal factors of violent incidents were market issues, fires, and religious crises. Matters related to sorcery and land issues did not appear at all as causes. Returning to one of the leading three causes, political crises caused the greatest number of incidents, particularly in 2007 and 2011, which both happened to be election years in the country. Similar to a number of other states, political tensions usually rise in Sokoto before, during, and after elections.

Table 10.3 Violent incidents in Gwadabawa LGA (June 2006-May 2014)

\begin{tabular}{|c|c|c|l|l|c|}
\hline S/N & Date & Community & Cause & Description & $\begin{array}{c}\text { No. of } \\
\text { deaths }\end{array}$ \\
\hline 1 & 2006 & Tungar Zaki & Cattle grazing & Fulani vs. farmers & 7 \\
\hline 2 & 2006 & $\begin{array}{c}\text { Tungar } \\
\text { Shanu }\end{array}$ & Cattle grazing & Fulani vs. farmers & 1 \\
\hline 3 & 2006 & Kola & Cattle grazing & Fulani vs. farmers & 1 \\
\hline 4 & 2006 & Kaura Huchi & Cattle grazing & Fulani vs. farmers & 3 \\
\hline 5 & 2006 & $\begin{array}{c}\text { Lukuwa Tu- } \\
\text { du }\end{array}$ & Cattle grazing & Fulani vs. farmers & 1 \\
\hline 6 & 2006 & Chimola & Cattle grazing & Hausa vs. Fulani & 1 \\
\hline 7 & 2006 & Gidan Kaya & Cattle grazing & Fulani vs. farmers & 1 \\
\hline 8 & 2006 & Buzan Lega & Cattle grazing & Fulani vs. farmers & 1 \\
\hline
\end{tabular}


Table 10.3 Violent incidents in Gwadabawa LGA (June 2006-May 2014), continued

\begin{tabular}{|c|c|c|c|c|c|}
\hline 10 & 2006 & Gigane & Cattle grazing & Fulani vs. farmers & 1 \\
\hline 11 & 2006 & Here village & Cattle grazing & Fulani vs. farmers & 2 \\
\hline 12 & 2006 & $\begin{array}{l}\text { Tungan } \\
\text { Shanu }\end{array}$ & Land issue & $\begin{array}{l}\text { Land struggle led to violence } \\
\text { between members of the com- } \\
\text { munity }\end{array}$ & 3 \\
\hline 13 & 2006 & Gidan Kaya & Crime & $\begin{array}{l}\text { Armed robbers murdered an } \\
\text { individual }\end{array}$ & 1 \\
\hline 14 & 2006 & Asara & Sorcery & $\begin{array}{l}\text { Community members arrested } \\
\text { and killed a suspected sorcerer }\end{array}$ & 1 \\
\hline 15 & 2006 & Gwadabawa & Car accident & $\begin{array}{l}\text { A lorry ran into an electric pole } \\
\text { and exploded, electrocuting two } \\
\text { individuals }\end{array}$ & 2 \\
\hline 16 & 2006 & Gwadabawa & Crime & $\begin{array}{l}\text { A fight broke out between } \\
\text { Gwadabawa youth and the } \\
\text { National Drug Law Enforce- } \\
\text { ment Agency (NDLEA) }\end{array}$ & 1 \\
\hline 17 & 2006 & Gwadabawa & Crime & $\begin{array}{l}\text { A Yoruba woman threw her } \\
\text { child into a well }\end{array}$ & 1 \\
\hline 18 & 2006 & Gwadabawa & Land issue & Inheritance battle & 1 \\
\hline 19 & 2006 & Zangiru & Crime & $\begin{array}{l}\text { Execution of armed robber by } \\
\text { community }\end{array}$ & 1 \\
\hline 20 & 2006 & Darma & Cattle grazing & Fulani vs. farmers & 1 \\
\hline 21 & 2006 & $\begin{array}{l}\text { Tungar } \\
\text { Bugaje }\end{array}$ & Religious issue & Yan Shi’a vs. Tijaniyya & 2 \\
\hline 22 & 2007 & Dangero & Cattle grazing & Fulani vs. farmers & 1 \\
\hline 23 & 2007 & Tungar Zaki & Cattle grazing & Fulani vs. farmers & 8 \\
\hline 24 & 2007 & Kagoye & Cattle grazing & Fulani vs. Hausa & 1 \\
\hline 25 & 2007 & Kagara & Cattle grazing & Fulani vs. farmers & 1 \\
\hline 26 & 2007 & Chimola & Cattle grazing & Fulani vs. farmers & 1 \\
\hline 27 & 2007 & Buzan Lega & Cattle grazing & Fulani vs. farmers & 1 \\
\hline 28 & 2007 & $\begin{array}{l}\text { Mamman } \\
\text { Suka }\end{array}$ & Cattle grazing & Fulani vs. farmers & 1 \\
\hline 29 & 2007 & Tsolawa & Cattle grazing & Fulani vs. farmers & 5 \\
\hline 30 & 2007 & Kulalo & Cattle grazing & Fulani vs. farmers & 3 \\
\hline 31 & 2007 & Gwadabawa & Car accident & $\begin{array}{l}\text { A fatal accident involving two } \\
\text { cars in a head-on collision }\end{array}$ & 25 \\
\hline 32 & 2007 & Male & Religious issue & Yan Shi'a vs. Tijaniyya & 3 \\
\hline 33 & 2007 & Rugar Mande & Cattle grazing & Fulani vs. farmers & 3 \\
\hline 34 & 2007 & Kola & Crime & $\begin{array}{l}\text { Asariya group vs. Gubudiyya } \\
\text { group during gathering in the } \\
\text { town }\end{array}$ & 1 \\
\hline 35 & 2007 & $\begin{array}{l}\text { Tungar } \\
\text { Shanu }\end{array}$ & Political crisis & $\begin{array}{l}\text { Allocation of government pro- } \\
\text { jects by the ruling party DPP } \\
\text { led to a disagreement with PDP } \\
\text { (opposition) }\end{array}$ & 3 \\
\hline
\end{tabular}


Table 10.3 Violent incidents in Gwadabawa LGA (June 2006-May 2014), continued

\begin{tabular}{|c|c|c|c|c|c|}
\hline 36 & 2007 & Gwadabawa & Political crisis & $\begin{array}{l}\text { DPP's LGA chairman allegedly } \\
\text { prompted the PDP opposition } \\
\text { party into violent demonstra- } \\
\text { tions owing to complaints of } \\
\text { injustice }\end{array}$ & 1 \\
\hline 37 & 2007 & $\begin{array}{l}\text { Tungar } \\
\text { Kwangi }\end{array}$ & Political crisis & $\begin{array}{l}\text { Opposition ANPP complained } \\
\text { of violation of 'sharing formu- } \\
\text { la' by PDP }\end{array}$ & 3 \\
\hline 38 & 2007 & Chimola & Political crisis & $\begin{array}{l}\text { A complaint of election rigging } \\
\text { caused a brutal fight between } \\
\text { PDP and DPP supporters }\end{array}$ & 4 \\
\hline 39 & 2007 & Gidan Kwano & Political crisis & $\begin{array}{l}\text { PDP complained of violation of } \\
\text { 'sharing formula' by ANPP, } \\
\text { leading to violence }\end{array}$ & 3 \\
\hline 40 & 2007 & Tungar Dillu & Political crisis & $\begin{array}{l}\text { Election result opposed by PDP } \\
\text { supporters }\end{array}$ & 1 \\
\hline 41 & 2008 & $\begin{array}{l}\text { Dan Gero } \\
\text { Salame }\end{array}$ & Cattle grazing & Fulani vs. farmers & 1 \\
\hline 42 & 2008 & Tungar Zaki & Cattle grazing & Fulani vs. farmers & 5 \\
\hline 43 & 2008 & $\begin{array}{l}\text { Tungar } \\
\text { Shanu }\end{array}$ & Cattle grazing & Fulani vs. farmers & 1 \\
\hline 44 & 2008 & $\begin{array}{l}\text { Chimola } \\
\text { (Tajaye) }\end{array}$ & Cattle grazing & Fulani vs. farmers & 1 \\
\hline 45 & 2008 & Asara & Cattle grazing & Fulani vs. farmers & 1 \\
\hline 46 & 2008 & Atakwanyo & Cattle grazing & Fulani vs. farmers & 2 \\
\hline 47 & 2008 & Gidan Karna & Cattle grazing & Fulani vs. farmers & 1 \\
\hline 48 & 2008 & $\begin{array}{c}\text { Tungan Mani } \\
\text { Dan Kasari }\end{array}$ & Cattle grazing & Fulani vs. farmers & 3 \\
\hline 49 & 2008 & Kalaba & Cattle grazing & Fulani vs. farmers & 1 \\
\hline 50 & 2008 & Dan Sitti & Cattle grazing & Fulani vs. farmers & 2 \\
\hline 51 & 2008 & Dan Burunje & Car accident & $\begin{array}{l}\text { A motorcyclist collided with a } \\
\text { car at a sharp bend in the road }\end{array}$ & 3 \\
\hline 52 & 2008 & Gidan Kaya & Political crisis & $\begin{array}{l}\text { Alleged election rigging } \\
\text { pitched DPP against ANPP } \\
\text { supporters }\end{array}$ & 1 \\
\hline 53 & 2008 & Tudun Doki & Political crisis & $\begin{array}{l}\text { Political rally of ruling DPP led } \\
\text { to violence with opposition } \\
\text { ANPP }\end{array}$ & 1 \\
\hline 54 & 2009 & Tungar Barga & Cattle grazing & Fulani vs. farmers & 3 \\
\hline 55 & 2009 & $\begin{array}{l}\text { Tungar } \\
\text { Shanu }\end{array}$ & Cattle grazing & Fulani vs. farmers & 3 \\
\hline 56 & 2009 & Lahodu & Cattle grazing & Fulani vs. farmers & 1 \\
\hline 57 & 2009 & Kagoye & Cattle grazing & Fulani vs. farmers & 1 \\
\hline 58 & 2009 & Kwalango & Cattle grazing & Fulani vs. farmers & 3 \\
\hline 59 & 2009 & Ranganda & Cattle grazing & Fulani vs. farmers & 3 \\
\hline
\end{tabular}


Table 10.3 Violent incidents in Gwadabawa LGA (June 2006-May 2014), continued

\begin{tabular}{|c|c|c|c|c|c|}
\hline 60 & 2009 & Gwadabawa & Car accident & $\begin{array}{l}\text { A car crashed owing to faulty } \\
\text { wheels }\end{array}$ & 2 \\
\hline 61 & 2009 & Gwadabawa & Car accident & $\begin{array}{l}\text { A commercial motorcyclist and } \\
\text { passenger were crushed by a } \\
\text { car }\end{array}$ & 2 \\
\hline 62 & 2009 & Mammande & Crime & Armed robbery attack & 11 \\
\hline 63 & 2009 & Matse & Other accident & A tree fell on a man & 1 \\
\hline 64 & 2009 & Chimola & Cattle grazing & Fulani vs. farmers & 1 \\
\hline 65 & 2010 & Millela & Cattle grazing & Fulani vs. farmers & 1 \\
\hline 66 & 2010 & $\begin{array}{l}\text { Kwank- } \\
\text { wanawa }\end{array}$ & Cattle grazing & Fulani vs. farmers & 1 \\
\hline 67 & 2010 & $\begin{array}{l}\text { Tungar Mal- } \\
\text { lam }\end{array}$ & Cattle grazing & Fulani vs. farmers & 2 \\
\hline 68 & 2010 & Hunchi & Cattle grazing & Fulani vs. farmers & 1 \\
\hline 69 & 2010 & Mammande & Cattle grazing & Fulani vs. farmers & 3 \\
\hline 70 & 2010 & $\begin{array}{l}\text { Gorgawo } \\
\text { village }\end{array}$ & Cattle grazing & Fulani vs. farmers & 1 \\
\hline 71 & 2010 & Takalmawa & Cattle grazing & Fulani vs. farmers & 1 \\
\hline 72 & 2010 & Here village & Cattle grazing & Fulani vs. farmers & 1 \\
\hline 73 & 2010 & Lukuwa Rafi & Natural disaster & $\begin{array}{l}\text { Gworonyo Dam over-flowed, } \\
\text { flooding villages situated close } \\
\text { to a river }\end{array}$ & 9 \\
\hline 74 & 2010 & Yar Tunga & Religious issue & Yan Shi'a vs. Tijaniyya & 1 \\
\hline 75 & 2011 & Lukuwa & Natural disaster & $\begin{array}{l}\text { Gworonyo Dam over-flowed, } \\
\text { flooding villages along a river }\end{array}$ & 2 \\
\hline 76 & 2011 & Tungar Tudu & Religious issue & Yan Shi'a vs. Tijaniyya & 3 \\
\hline 77 & 2011 & Burdi & Religious issue & Yan Shi'a vs. Tijaniyya & 1 \\
\hline 78 & 2011 & $\begin{array}{l}\text { Kwank- } \\
\text { wanawa }\end{array}$ & Religious issue & Yan Shi'a vs. Tijaniyya & 3 \\
\hline 79 & 2011 & Millela & Cattle grazing & Fulani vs. farmers & 2 \\
\hline 80 & 2011 & Mammande & Cattle grazing & Fulani vs. farmers & 1 \\
\hline 81 & 2011 & Darna & Cattle grazing & Fulani vs. farmers & 1 \\
\hline 82 & 2011 & Dan Fanga & Cattle grazing & Fulani vs. farmers & 1 \\
\hline 83 & 2011 & Tunga Zaki & Cattle grazing & Fulani vs. farmers & 1 \\
\hline 84 & 2011 & Salame & Car accident & $\begin{array}{l}\text { A car ran into a mud house, } \\
\text { killing the driver }\end{array}$ & 1 \\
\hline 85 & 2011 & $\begin{array}{l}\text { Tungar Ma- } \\
\text { dugu }\end{array}$ & Political crisis & $\begin{array}{l}\text { Supporters of the ruling DPP } \\
\text { clashed with the opposition } \\
\text { ANPP }\end{array}$ & 3 \\
\hline 86 & 2011 & Salame & Political crisis & $\begin{array}{l}\text { ANPP supporters attacked the } \\
\text { convoy of the LGA chairman }\end{array}$ & 1 \\
\hline 87 & 2012 & Kiliya & Cattle grazing & Fulani vs. farmers & 1 \\
\hline 88 & 2012 & Tungar Zaki & Cattle grazing & Fulani vs. farmers & 3 \\
\hline 89 & 2012 & Kola & Cattle grazing & Fulani vs. farmers & 1 \\
\hline 90 & 2012 & Dan Fanga & Cattle grazing & Fulani vs. farmers & 3 \\
\hline 91 & 2012 & Chanca & Cattle grazing & Fulani vs. farmers & 1 \\
\hline 92 & 2012 & Tsolawa & Cattle grazing & Fulani vs. farmers & 1 \\
\hline 93 & 2012 & Jihadi & Cattle grazing & Fulani vs. farmers & 1 \\
\hline
\end{tabular}


Table 10.3 Violent incidents in Gwadabawa LGA (June 2006-May 2014), continued

\begin{tabular}{|c|c|c|c|c|c|}
\hline 94 & 2012 & $\begin{array}{l}\text { Tunga } \\
\text { Bugaje }\end{array}$ & Other accident & $\begin{array}{l}\text { A weak wall fell on the occu- } \\
\text { pants of a house }\end{array}$ & 5 \\
\hline 95 & 2012 & Tungar Zaki & Car accident & $\begin{array}{l}\text { A motorcyclist lost control and } \\
\text { crashed through a broken } \\
\text { bridge }\end{array}$ & 4 \\
\hline 96 & 2012 & Tungar Jeje & Car accident & $\begin{array}{l}\text { A driver lost control of his car } \\
\text { and died }\end{array}$ & 1 \\
\hline 97 & 2012 & Dan Burunje & Cattle grazing & Fulani vs. farmers & 1 \\
\hline 98 & 2012 & Gangada & Political crisis & $\begin{array}{l}\text { Campaign rally involving vio- } \\
\text { lence between DPP and PDP }\end{array}$ & 1 \\
\hline 99 & 2012 & Mele & Political crisis & $\begin{array}{l}\text { Opposition ANPP complained } \\
\text { of violation of 'sharing formu- } \\
\text { la' by PDP }\end{array}$ & 2 \\
\hline 100 & 2013 & $\begin{array}{l}\text { Kwank- } \\
\text { wanawa }\end{array}$ & Cattle grazing & Fulani vs. farmers & 1 \\
\hline 101 & 2013 & Dangero & Cattle grazing & Fulani vs. farmers & 3 \\
\hline 102 & 2013 & $\begin{array}{l}\text { Tungar } \\
\text { Bugaje }\end{array}$ & Cattle grazing & Fulani vs. farmers & 3 \\
\hline 103 & 2013 & Kagara & Cattle grazing & Fulani vs. farmers & 1 \\
\hline 104 & 2013 & Asara & Cattle grazing & Fulani vs. farmers & 1 \\
\hline 105 & 2013 & $\begin{array}{l}\text { Tungar Dan } \\
\text { Dolo }\end{array}$ & Cattle grazing & Fulani vs. farmers & 2 \\
\hline 106 & 2013 & Salame & Market issue & $\begin{array}{l}\text { Dispute regarding the location } \\
\text { of a market caused violence }\end{array}$ & 1 \\
\hline 107 & 2013 & $\begin{array}{l}\text { Tungan } \\
\text { Bugaje }\end{array}$ & Other accident & $\begin{array}{l}\text { A dilapidated mud house col- } \\
\text { lapsed, killing its occupants }\end{array}$ & 3 \\
\hline 108 & 2013 & Salame & Car accident & $\begin{array}{l}\text { Head-on collision involving } \\
\text { two cars led to the death of one } \\
\text { of the drivers }\end{array}$ & 1 \\
\hline 109 & 2013 & Gwanja & Cattle grazing & Fulani vs. farmers & 1 \\
\hline 110 & 2013 & Mammande & Religious issue & Yan Shi'a vs. Tijaniyya & 1 \\
\hline 111 & 2013 & Gwadabawa & Car accident & A truck crushed a motorcyclist & 1 \\
\hline 112 & 2013 & Kuliya & Religious crisis & Yan Shi'a vs. Tijaniyya & 3 \\
\hline 113 & 2014 & Kaime & Cattle grazing & Fulani vs. farmers & 1 \\
\hline 114 & 2014 & Gwadabawa & Other accident & $\begin{array}{l}\text { A person fell into a well and } \\
\text { was found dead after two days }\end{array}$ & 1 \\
\hline 115 & 2014 & Salame & Car accident & $\begin{array}{l}\text { A motorcyclist crashed into a } \\
\text { ditch }\end{array}$ & 1 \\
\hline 116 & 2014 & Salame & Car accident & $\begin{array}{l}\text { A car crashed through a bridge, } \\
\text { killing its driver }\end{array}$ & 1 \\
\hline 117 & 2014 & Salame & Car accident & $\begin{array}{l}\text { A car driver lost control and } \\
\text { crashed into a market, killing } \\
\text { one individual }\end{array}$ & 1 \\
\hline 118 & 2014 & $\begin{array}{l}\text { Tungar } \\
\text { Shanu }\end{array}$ & Car accident & $\begin{array}{l}\text { A motorcyclist died following } \\
\text { collision with a stationary car }\end{array}$ & 1 \\
\hline 119 & 2014 & $\begin{array}{l}\text { Tungar Mai } \\
\text { Komo }\end{array}$ & Car accident & $\begin{array}{l}\text { A motorcyclist lost control and } \\
\text { died following collision in a } \\
\text { crowded area }\end{array}$ & 1 \\
\hline 120 & 2014 & Salame & Other accident & A child fell into a well & 1 \\
\hline
\end{tabular}

Source: Fieldwork, August-September 2014 
Compared with Gudu, Gwadabawa LGA experienced a slightly lower number of violent incidents (120) and fatalities (253) across 68 wards and communities between 2006 and 2014 (Table 10.3). The predominant cause of violent incidents was cattle grazing (68 incidents), ${ }^{5}$ followed by car accidents (15) and political crises (12). Sorcery, market issues, natural disasters, and land issues constituted the least frequent causal factors linked with violent incidents in the LGA. In terms of years, 2006, followed closely by 2007, witnessed the highest number of violent incidents, among which the number of conflicts involving farmers and Fulani cattle herdsmen were considerable. Although religious crisis was associated with only eight violent incidents, all involved clashes between the Yan Shi'a and the Sufi brotherhood known as the Tijaniyya. This significant number of incidents involving the Yan Shi'a exceeds the number in Gwadabawa LGA and, indeed, fits a broader pattern of religious-related crisis involving the group in some other parts of Sokoto State, such as in Sokoto North and Sokoto South LGAs. ${ }^{6}$

Table 10.4 Violent incidents in Illela LGA (June 2006-May 2014)

\begin{tabular}{|c|c|c|c|l|c|}
\hline S/N & Date & Community & Cause & \multicolumn{1}{|c|}{ Description } & $\begin{array}{c}\text { No. of } \\
\text { deaths }\end{array}$ \\
\hline 1 & 2006 & Gaidau & Political crisis & $\begin{array}{l}\text { Two opposing political parties, PDP } \\
\text { and DPP, clashed over differences } \\
\text { in interest }\end{array}$ & 3 \\
\hline 2 & 2006 & Illela Araba & Sorcery & Conflict between husband and wife & 1 \\
\hline 3 & 2006 & $\begin{array}{l}\text { Gidan Hamma, } \\
\text { Gidan Katta }\end{array}$ & Fire accident & Explosion & 1 \\
\hline 4 & 2006 & Illela District & Crime & $\begin{array}{l}\text { Incident involving the Hausa vs. } \\
\text { Adarawa community }\end{array}$ & 1 \\
\hline 5 & 2006 & Illela Stadium & Crime & $\begin{array}{l}\text { Incident involving the Araba vs. } \\
\text { Amarawa football clubs }\end{array}$ & 1 \\
\hline 6 & 2006 & Gidan Kwanni & Crime & $\begin{array}{l}\text { Incident involving the Nigerian } \\
\text { army against armed robbers }\end{array}$ & 5 \\
\hline 7 & 2007 & Kan Wuri & Political crisis & DPP vs. ACN supporters & 2 \\
\hline 8 & 2007 & Gidan Katta & Political crisis & PDP vs. DPP supporters & 2 \\
\hline 9 & 2007 & Zugana & Political crisis & PDP vs. CPC supporters & 5 \\
\hline 10 & 2007 & Tudun Gudali & Political crisis & PDP vs. DPP supporters & 1 \\
\hline 11 & 2007 & Gidan Ayuba & Political crisis & PDP vs. ANPP supporters & 3 \\
\hline
\end{tabular}

5 Some of the interviews conducted at the Sokoto State Police Command Headquarters helped to confirm the seriousness of issues arising from cattle grazing in several parts of the state. As the tables show, nearly all the incidents involve clashes between Fulani herdsmen and Hausa farmers.

6 There have been a number of past violent incidents involving Yan Shi'a members, such as clashes in 2005 and 2007, as well as more recent encounters in November 2014 during a Yan Shi'a procession in Sokoto metropolis in Sokoto South LGA. Fieldwork for this study coincided with the period when a Yan Shi'a procession took place; and although there were no reported fatalities, some individuals were injured. 
Table 10.4 Violent incidents in Illela LGA (June 2006-May 2014), continued

\begin{tabular}{|c|c|c|c|c|c|}
\hline 12 & 2007 & Yar Kwalbati & Political crisis & PDP vs. CPC supporters & 1 \\
\hline 13 & 2007 & Illela District & Political crisis & PDP vs. DPP supporters & 1 \\
\hline 14 & 2007 & Gidan Hamma & Political crisis & PDP vs. ANPP supporters & 1 \\
\hline 15 & 2007 & Gidan Kwanni & \begin{tabular}{|c|}
$\begin{array}{c}\text { Natural disas- } \\
\text { ter }\end{array}$ \\
\end{tabular} & Flooding (water) & 5 \\
\hline 16 & 2007 & Yar Marina & Religious crisis & Yan Izala vs. Tijaniyya & 2 \\
\hline 17 & 2007 & Danbar Dikko & Cattle grazing & Fulani vs. Fulani & 6 \\
\hline 18 & 2008 & Sandaga & Political crisis I & PDP vs. DPP supporters & 3 \\
\hline 19 & 2008 & Central Market & Market issue & $\begin{array}{l}\text { Conflict over land matter in the } \\
\text { market }\end{array}$ & 1 \\
\hline 20 & 2008 & Illela Araba & Fire accident & Explosion & 3 \\
\hline 21 & 2008 & Illela Central & $\begin{array}{c}\text { Natural disas- } \\
\text { ter }\end{array}$ & $\begin{array}{l}\text { Flood occurred owing to lack of } \\
\text { drainage }\end{array}$ & 1 \\
\hline 22 & 2008 & Nasarawa & $\begin{array}{c}\text { Natural disas- } \\
\text { ter }\end{array}$ & $\begin{array}{l}\text { Heavy rain caused flooding and } \\
\text { deaths and left people homeless }\end{array}$ & 3 \\
\hline 23 & 2008 & Dan Boka & \begin{tabular}{|c|}
$\begin{array}{c}\text { Natural disas- } \\
\text { ter }\end{array}$ \\
\end{tabular} & Flooding & 3 \\
\hline 24 & 2008 & Kan Wuri & Religious crisis & Yan Shi’a vs. Yan Izala & 5 \\
\hline 25 & 2008 & Illela & Religious crisis & Yan Izala vs. Tijaniyya & 2 \\
\hline 26 & 2008 & Yar Tsakkuwa & Cattle grazing 1 & Fulani vs. farmers & 1 \\
\hline 27 & 2008 & Anbarura & Cattle grazing & Fulani vs. farmers & 11 \\
\hline 28 & 2008 & Illela Central & Land issue & Fulani vs. Hausa & 3 \\
\hline 29 & 2009 & Munwadata & Cattle grazing & Fulani vs. Hausa & 10 \\
\hline 30 & 2009 & Gidan Ayuba & Fire accident & The house of a family caught fire & 2 \\
\hline 31 & 2009 & Yar Marina & Market issue & Conflict over market transaction & 2 \\
\hline 32 & 2009 & Dan Boka & Religious crisis & Yan Izala vs. Tijaniyya & 1 \\
\hline 33 & 2009 & Amarawa & Cattle grazing & Fulani vs. Fulani & 2 \\
\hline 34 & 2009 & Tudun & Cattle grazing & Fulani vs. Hausa & 5 \\
\hline 35 & 2009 & Hura & Cattle grazing & Fulani vs. farmers & 1 \\
\hline 36 & 2009 & Gidan Ayuba & Crime & Hooligans attacked strangers & 4 \\
\hline 37 & 2009 & Dan Bar Dikko & Crime & $\begin{array}{l}\text { Community defence against armed } \\
\text { robbers }\end{array}$ & 4 \\
\hline 38 & 2010 & Kalmano & Political crisis & PDP vs. CPC supporters & 3 \\
\hline 39 & 2010 & Danba Fulani & Fire accident & Explosion in a village & 3 \\
\hline 40 & 2010 & Dan Birema & Religious crisis & Yan Izala vs. Tijaniyya & 4 \\
\hline 41 & 2011 & Illela Araba & Political crisis & PDP vs. DPP supporters & 1 \\
\hline 42 & 2011 & Ambarura & Political crisis & PDP vs. ACN supporters & 2 \\
\hline 43 & 2011 & $\begin{array}{l}\text { Gaidau Chi- } \\
\text { wake }\end{array}$ & Political crisis & PDP vs. CPC supporters & 1 \\
\hline 44 & 2011 & Tudun Gudale & Fire accident & Explosion incident & 1 \\
\hline 45 & 2011 & Gidan Hamma & \begin{tabular}{|l|l} 
Fire accident \\
\end{tabular} & Fire disaster in a village & 1 \\
\hline 46 & 2011 & Tambagarka & Market issue & Hawkers vs. traders in market stalls & 5 \\
\hline 47 & 2011 & Illela District & Religious crisis & Yan Shi'a vs. Yan Izala & 3 \\
\hline 48 & 2011 & Ambarura & Religious crisis & Qadiriyya vs. Yan Izala & 1 \\
\hline 49 & 2011 & Danbar Dikko & Religious crisis & Yan Izala vs. Tijaniyya & 2 \\
\hline
\end{tabular}


Table 10.4 Violent incidents in Illela LGA (June 2006-May 2014), continued

\begin{tabular}{|c|c|c|c|c|c|}
\hline 50 & 2011 & Kalmalo & Cattle grazing & Fulani vs. Hausa & 2 \\
\hline 51 & 2011 & Dan Kuda & Crime & $\begin{array}{l}\text { Amarawa vs. Kalmalo football } \\
\text { clubs }\end{array}$ & 1 \\
\hline 52 & 2011 & Amarawa & Crime & $\begin{array}{l}\text { Supporters of Real Madrid vs. } \\
\text { Barcelona football clubs }\end{array}$ & 3 \\
\hline 53 & 2012 & Kara & Political crisis & PDP vs. CPC supporters & 2 \\
\hline 54 & 2012 & $\begin{array}{l}\text { Tudun } \\
\text { Gudale }\end{array}$ & Political crisis & PDP vs. ACN supporters & 1 \\
\hline 55 & 2012 & $\begin{array}{c}\text { Gidan Ham- } \\
\text { ma }\end{array}$ & $\begin{array}{c}\text { Natural disas- } \\
\text { ter }\end{array}$ & Heavy rain & 8 \\
\hline 56 & 2012 & Amarawa & $\begin{array}{l}\text { Religious } \\
\text { crisis }\end{array}$ & Yan Izala vs. Tijaniyya & 5 \\
\hline 57 & 2012 & Illela District & $\begin{array}{l}\text { Religious } \\
\text { crisis }\end{array}$ & $\begin{array}{l}\text { Yan Izala vs. Tijaniyya, involving } \\
\text { the police }\end{array}$ & 4 \\
\hline 58 & 2012 & Yar Marina & Crime & $\begin{array}{l}\text { Yar Marina vs. Madatsawa football } \\
\text { clubs }\end{array}$ & 2 \\
\hline 59 & 2012 & Illela & Car accident & Due to bad roads & 1 \\
\hline 60 & 2012 & $\begin{array}{c}\text { Gaidau Chi- } \\
\text { wake }\end{array}$ & Car accident & Due to bad roads & 3 \\
\hline 61 & 2012 & Yar Kwalbati & Car accident & $\begin{array}{l}\text { Motorcycle accident between } \\
\text { Kwalbati and a market }\end{array}$ & 1 \\
\hline 62 & 2013 & Amarawa & Crime & Armed robbers vs. residents & 1 \\
\hline 63 & 2013 & Madatsa & Political crisis & PDP vs. DPP supporters & 3 \\
\hline 64 & 2013 & Gidan Katta & Political crisis & PDP vs. APC supporters & 2 \\
\hline 65 & 2013 & Illela & Political crisis & PDP vs. APC supporters & 1 \\
\hline 66 & 2013 & Dan Boko & Political crisis & PDP vs. APC supporters & 1 \\
\hline 67 & 2013 & Illela Araba & Political crisis & DPP vs. APC supporters & 1 \\
\hline 68 & 2013 & Machesare & Cattle grazing & Fulani vs. farmers & 1 \\
\hline 69 & 2013 & Illela & Fire accident & Incident occurred in a market & 2 \\
\hline 70 & 2013 & Illela Nasara & Fire accident & Fuel station gutted by fire & 3 \\
\hline 71 & 2013 & Illela Araba & $\begin{array}{l}\text { Oil distribu- } \\
\text { tion }\end{array}$ & $\begin{array}{l}\text { Oil distribution led to violence in } \\
\text { town }\end{array}$ & 1 \\
\hline 72 & 2013 & Zugana & Fire accident & Fire incident killed one individual & 1 \\
\hline 73 & 2013 & Kalmano & $\begin{array}{c}\text { Natural disas- } \\
\text { ter }\end{array}$ & Flooding & 3 \\
\hline 74 & 2013 & $\begin{array}{l}\text { Illela Yar } \\
\text { Kara }\end{array}$ & $\begin{array}{c}\text { Natural disas- } \\
\text { ter }\end{array}$ & Flooding & 1 \\
\hline 75 & 2013 & $\begin{array}{l}\text { Illela Yar } \\
\text { Kara }\end{array}$ & $\begin{array}{l}\text { Religious } \\
\text { crisis }\end{array}$ & Yan Shi'a vs. Nigerian Army & 10 \\
\hline 76 & 2013 & Illela Araba & Political crisis & PDP vs. APC supporters & 1 \\
\hline 77 & 2013 & Illela Araba & $\begin{array}{l}\text { Religious } \\
\text { crisis }\end{array}$ & Yan Shi'a vs. Tijaniyya & 3 \\
\hline 78 & 2013 & Kalmano & Cattle grazing & Hausa farmers vs. Fulani nomads & 11 \\
\hline 79 & 2013 & Ambarura & Cattle grazing & Fulani vs. Nigerian Police & 1 \\
\hline 80 & 2013 & Danba & Land issue & Fulani vs. Hausa & 4 \\
\hline 81 & 2013 & $\begin{array}{c}\begin{array}{c}\text { Illela Wood } \\
\text { Zone }\end{array} \\
\end{array}$ & Crime & $\begin{array}{l}\text { Commercial motorcyclist vs. angry } \\
\text { mob }\end{array}$ & 3 \\
\hline
\end{tabular}


Table 10.4 Violent incidents in Illela LGA (June 2006-May 2014), continued

\begin{tabular}{|c|c|c|c|c|c|}
\hline 82 & 2013 & Kalmanu & Political crisis & $\begin{array}{l}\text { Local government staff vs. Kal- } \\
\text { manu community }\end{array}$ & 2 \\
\hline 83 & 2013 & Sanke & Crime & $\begin{array}{l}\text { Hooligans vs. commercial motor- } \\
\text { cyclist }\end{array}$ & 1 \\
\hline 84 & 2013 & Illela Stadium & Crime & $\begin{array}{l}\text { Gaidau Chiwake football club vs. } \\
\text { Gidan Hamma football club }\end{array}$ & 1 \\
\hline 85 & 2013 & Dogon Karfe & Crime & Armed robbers vs. community & 2 \\
\hline 86 & 2013 & Kwanni road & Car accident & Due to bad roads & 2 \\
\hline 87 & 2013 & Ambaruru & Car accident & Due to bad roads & 1 \\
\hline 88 & 2013 & Karangiya & Car accident & Due to bad roads & 1 \\
\hline 89 & 2013 & Kanwuri & Car accident & Due to over-speeding & 3 \\
\hline 90 & 2013 & Tuddun Wada & Car accident & Due to over-speeding & 1 \\
\hline 91 & 2013 & Dogon Karfe & Car accident & Due to bad roads & 10 \\
\hline 92 & 2013 & Dan Boka & Car accident & Due to bad roads & 3 \\
\hline 93 & 2014 & Illela Araba & Political crisis & PDP vs. APC supporters & 1 \\
\hline 94 & 2014 & Illela Town & Car accident & $\begin{array}{l}\text { Car owner, a relative, and three } \\
\text { other victims }\end{array}$ & 5 \\
\hline 95 & 2014 & Amarawa & Land issue & Fulani vs. farmers & 2 \\
\hline 96 & 2014 & Dogun Karhe & Car accident & Fatal car crash & 12 \\
\hline 97 & 2014 & Illela Araba & $\begin{array}{l}\text { Natural } \\
\text { disaster }\end{array}$ & Flooding & 1 \\
\hline 98 & 2014 & Gidan Hamma & $\begin{array}{l}\text { Religious } \\
\text { crisis }\end{array}$ & Yan Izala vs. Tijaniyya & 1 \\
\hline 99 & 2014 & Illela District & Crime & $\begin{array}{l}\text { A criminal stole a Kasea motorcycle } \\
\text { and was later killed }\end{array}$ & 1 \\
\hline 100 & 2014 & Kara & Crime & $\begin{array}{l}\text { Hooligans (Area Boys) vs. commu- } \\
\text { nity elders }\end{array}$ & 1 \\
\hline 101 & 2014 & Gidan Katta & Car accident & Due to bad roads & 5 \\
\hline 102 & 2014 & Chiwaki & Car accident & Due to bad roads & 3 \\
\hline 103 & 2014 & Dogon Karfe & Car accident & $\begin{array}{l}\text { Fatal auto crash on the way from } \\
\text { Illela to Dogon Karfe }\end{array}$ & 10 \\
\hline
\end{tabular}

Source: Fieldwork, August-September 2014

In spite of a higher population than LGAs such as Gudu, Illela experienced a lower level of violent incidents and fatalities between 2006 and 2014 (Table 10.4). There were 103 unreported violent incidents resulting in 291 fatalities across at least 53 wards and communities. However, similar to Gudu, political crisis was the main cause of lethal violence, followed by 15 incidents associated with car accidents, which exactly matches the situation that transpired in Gwadabawa. As observed in Gudu and Gwadabawa, religious crisis again did not rank among the top three causes of fatal incidents in Illela. In fact, crime caused more violence in the LGA. Market and land conflicts, as well as issues pertaining to sorcery, were the least frequent causal factors of violent incidents. The year 2013 was the most violent year in Illela, measured by number of fatalities as well as 
frequency of incidents, the principal causes of which were political crisis (involving mainly the PDP and APC) and car accidents (due mainly to bad roads).

Table 10.5 Violent incidents in Sakaba LGA (June 2006-May 2014)

\begin{tabular}{|c|c|c|c|c|c|}
\hline $\mathrm{S} / \mathrm{N}$ & Date & Community & Cause & Description & $\begin{array}{l}\text { No. of } \\
\text { deaths }\end{array}$ \\
\hline 1 & 2006 & Makuku & Crime & $\begin{array}{l}\text { Attack led to the death of } 6 \\
\text { people }\end{array}$ & 6 \\
\hline 2 & 2006 & Laraba & Sorcery & $\begin{array}{l}\text { Cult member vs. commu- } \\
\text { nity }\end{array}$ & 4 \\
\hline 3 & 2006 & Jan-birnin & Crime & $\begin{array}{l}\text { Armed gang vs. communi- } \\
\text { ty }\end{array}$ & 1 \\
\hline 4 & 2006 & Doka & Sorcery & Act of witchcraft & 1 \\
\hline 5 & 2006 & Jan-birnin & Crime & $\begin{array}{l}\text { Armed gang and commu- } \\
\text { nity }\end{array}$ & 4 \\
\hline 6 & 2007 & Unguwar Yamma & Sorcery & $\begin{array}{l}\text { Ritual incident involving a } \\
\text { man and his elder brother }\end{array}$ & 2 \\
\hline 7 & 2007 & Doka & Sorcery & Act of witchcraft & 2 \\
\hline 8 & 2007 & Makuku & Crime & $\begin{array}{l}\text { Armed gang against mem- } \\
\text { bers of the community }\end{array}$ & 8 \\
\hline 9 & 2008 & Doka & Sorcery & $\begin{array}{l}\text { An alleged witch was } \\
\text { killed by members of the } \\
\text { community }\end{array}$ & 1 \\
\hline 10 & 2008 & Dirin Daji & Crime & $\begin{array}{l}\text { Cult member vs. commu- } \\
\text { nity members }\end{array}$ & 2 \\
\hline 11 & 2008 & Makuku & Crime & $\begin{array}{l}\text { Armed gang vs. communi- } \\
\text { ty }\end{array}$ & 7 \\
\hline 12 & 2009 & Unguwar Yakkorau & Sorcery & Witch vs. community & 2 \\
\hline 13 & 2009 & Doka & Sorcery & Victim of witchcraft & 1 \\
\hline 14 & 2009 & Jan-birnin & Cattle grazing & Fulani vs. community & 2 \\
\hline 15 & 2010 & Diri Yakkoro & Sorcery & $\begin{array}{l}\text { A alleged witch killed } \\
\text { somebody and was later } \\
\text { also killed }\end{array}$ & 2 \\
\hline 16 & 2010 & Sakaba gari & Crime & $\begin{array}{l}\text { Armed gang vs. communi- } \\
\text { ty }\end{array}$ & 2 \\
\hline 17 & 2010 & Laraba village & Crime & Police vs. armed robbers & 3 \\
\hline 18 & 2010 & Agale town & Crime & $\begin{array}{l}\text { Armed gang vs. communi- } \\
\text { ty }\end{array}$ & 2 \\
\hline 19 & 2011 & Yakkorau Diri & Sorcery & $\begin{array}{l}\text { Woman killed by a group } \\
\text { of people }\end{array}$ & 2 \\
\hline 20 & 2011 & Rabe & Land issue & Fulani vs. Kambari & 5 \\
\hline 21 & 2011 & Yakkorau & Crime & $\begin{array}{l}\text { People killed during an } \\
\text { armed robbery attack }\end{array}$ & 9 \\
\hline
\end{tabular}


Table 10.5 Violent incidents in Sakaba LGA (June 2006-May 2014), continued

\begin{tabular}{|c|c|c|c|l|c|}
\hline 22 & 2011 & Dirin Daji & Crime & $\begin{array}{l}\text { Armed gang vs. police and } \\
\text { also involving community } \\
\text { members, during a robbery } \\
\text { incident }\end{array}$ & 7 \\
\hline 23 & 2011 & Shiyar & Land issue & $\begin{array}{l}\text { Communal violence over a } \\
\text { plot of land }\end{array}$ & 6 \\
\hline 24 & 2011 & Makuku & Crime & $\begin{array}{l}\text { Armed gang vs. communi- } \\
\text { ty }\end{array}$ & 9 \\
\hline 25 & 2012 & Yakoro & Sorcery & $\begin{array}{l}\text { An alleged witch killed a } \\
\text { man }\end{array}$ & 2 \\
\hline 26 & 2012 & Rabe & Land issue & $\begin{array}{l}\text { Clash over land claims } \\
\text { involving a Fulani indi- } \\
\text { vidual }\end{array}$ & 3 \\
\hline 27 & 2012 & Dankolo & Crime & Robbery incident & 1 \\
\hline 28 & 2012 & Dankolo & Cattle grazing & Fulani vs. farmers & 5 \\
\hline 29 & 2012 & Jan-birnin & Crime & $\begin{array}{l}\text { Armed gang vs. communi- } \\
\text { ty }\end{array}$ & 2 \\
\hline 30 & 2013 & Unguwar Wade & Land issue & $\begin{array}{l}\text { Farmland destroyed by a } \\
\text { Fulani man }\end{array}$ & 4 \\
\hline 31 & 2013 & Adeyi & Crime & $\begin{array}{l}\text { Gang vs. community dur- } \\
\text { ing a robbery incident }\end{array}$ & 1 \\
\hline 32 & 2013 & Sakaba & Crime & Armed robbery incident & 2 \\
\hline 33 & 2014 & Unguwar Wade & Land issue & $\begin{array}{l}\text { Fulani cattle breeders } \\
\text { claimed and destroyed } \\
\text { land of Dakarkaru farmers }\end{array}$ & 5 \\
\hline 34 & 2014 & Dankolo & Land issue & $\begin{array}{l}\text { Fulani cattle breeders vs. } \\
\text { Dakarkaru farmers }\end{array}$ & 6 \\
\hline 35 & 2014 & Rabe & Land issue & Fulani vs. Kambari & 5 \\
\hline 36 & 2014 & Rabe & Crime & $\begin{array}{l}\text { Armed gang vs. communi- } \\
\text { ty }\end{array}$ & 5 \\
\hline 37 & 2014 & Sakaba gari & Cattle grazing & Fulani vs. farmers & 5 \\
\hline 5 & & & & & 5 \\
\hline
\end{tabular}

Source: Fieldwork, August-September 2014

In Sakaba, the only LGA in Kebbi State examined in this study, a total of 37 violent incidents led to 136 fatalities in 20 wards and communities. The data obtained revealed only four categories of unreported violent incidents: crime, sorcery, land issues, and cattle grazing. Crime and sorcery ranked as the top two factors that resulted in violent incidents, while issues caused by political crises, religious disputes, and car accidents were unidentified. As noted in the introductory part of this paper, the limitations of human memory - for instance, the ability of Sakaba respondents to recall violent incidents relating to politics, religion, and car accidents - should not be entirely ruled out. Nevertheless, the fact that not a single incident within these categories was cited by any respondent underscores that they were not factors considered conspicuous enough to have caused any violent deaths during the period under investigation. In fact, as pointed out earli- 
er, certain parts of Sakaba are known to be severely affected by the problem of inaccessibility with cars. Hence, it is possible to understand the absence of motor accident fatalities in the LGA. Finally, the number of violent incidents and fatalities was highest in 2011, with approximately two-thirds of the total number of deaths attributed to crime - and specifically to armed robbery attacks.

\section{Explaining 'invisible' violence in Gudu, Gwadabawa, Illela and Sakaba LGAS}

Accounting for unreported violence in the four LGAs requires an understanding of a number of factors. The first relates to the physical location of some communities in the most far-flung geographical areas of a state. In the case of Sokoto, for instance, there is little dispute over the fact that in geostrategic terms it is situated far from the so-called centre of the country. In addition to harsher climatic conditions in the Sahel, this in a sense also influences the predisposition of people to prefer to migrate in search of economic opportunities in more cosmopolitan and industrial cities and states of Nigeria. Illela, for instance, happens to be one of the LGAs located in an extremely distant part of Sokoto State, and in fact it shares borders with another country (Niger). These factors together offer a perfect excuse to media organizations that may claim justification for not exploring such LGAs; but, at the same time, these organizations miss opportunities to report violent incidents when they do occur.

A second factor relates to the issue of inaccessibility, which is closely linked to the preceding factor but in an infrastructural context. In Sakaba, statistics thus show a complete absence of car accidents, because of the lack of tarred roads. In Illela LGA - where car accident was the second-most significant factor of lethal violence - nine out of a total of 15 such incidents were attributed to bad roads.

A third issue identified by respondents was the perceived insensitivity of local government officials and political representatives in a position of accountability towards the affected people. Some more critical respondents underscored the need for more effective representation of their communities in the political sphere. Compounding these challenges is also the manner in which these LGAs are perceived in terms of their economic worth in the eyes of the media as well as other stakeholders in the polity. If the people of these LGAs are not held in high regard by those accountable to them at the political level, this is also reflected in the attitude of media entities, who on their part are less willing to spend money, time, and energy in reporting from these rural regions. The study nonetheless found that there were a few instances where state and national media indeed reported violent incidents in some of the four LGAs under review. But such reporting falls short of providing sufficient details. It simply conveys basic information 
linked with the entire state, without mentioning the specific wards or communities affected. Several of such incomplete media reports can be found on the websites of various media organizations.

\section{Conclusion}

The data analysed for each of the four LGAs under review clearly shows a range of factors accounting for fatal violence, including cattle grazing, political crisis, crime, and car accident. Particular years were also exceptionally violent, such as 2011 and 2013. Gudu LGA in Sokoto State recorded the highest number of fatalities as well as violent incidents, while Sakaba LGA in Kebbi State had the lowest. Although religion was linked to certain clashes involving the Yan Shi'a, the Tijaniyya Sufi brotherhood, and the Yan Izala movement, it accounted for few incidents in all four LGAs. Worthy of note is that the overall data draws attention to an alarming level of lethal violence in oft-neglected rural areas of Sokoto and Kebbi states. 


\section{Postscript: The next challenge: Statistics as a tool for human security}

From the North to the South and the West to the East, many rural LGAs in Nigeria experience fatal incidents that are ignored by the media ... and by the security forces. In remote parts of Borno, Yobe, and Adamawa states, however, the Boko Haram insurgency has shown how dangerous such a vacuum can be. Today, the science of maintaining law and order is still in its infancy in Nigeria. The army does not publish records of its operations, and the police make no use of statistics to improve their performance. Moreover, citizens rarely request the release of such data.

In addition, Nigerian readers seldom find comments on the number of homicides nationwide or the body count of the Boko Haram crisis in the North-East, except for a few cases on the spot, such as the controversy over the death toll of another massacre in Baga, in January 2015. Unlike South Africa, crime statistics are not discussed in the media or in Parliament. Police press conferences sometimes provide small amounts of information, but figures are inconsistent and many analysts rely on their own perceptions without trying to substantiate their findings with hard facts. Among the general public, there are simply no debates on the methodology, the use, and the utility of statistics on violence.

This book represents an innovation: it is the first to introduce a discussion on such issues in a coherent manner, relying on a database that fills the lacunae in data from the security forces. The selection of chapters presented clearly demonstrates that, despite many challenges in the most populated country in Africa, it is quite possible to use statistics to improve our analysis of Nigeria. Indeed, it also confirms that it is necessary to do so in order to avoid stereotypes and the bias of emotional reactions to violence. Finally, it shows that combining qualitative and quantitative approaches is the best way to refine our understanding of human security. 


West African Politics and Society series 3

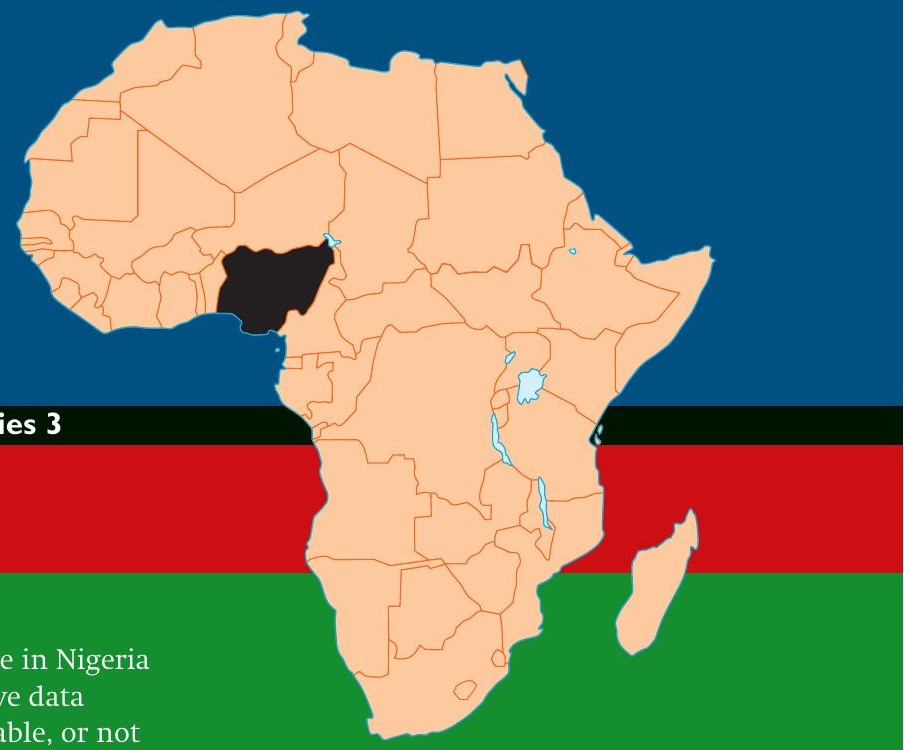

Most of the academic literature on violence in Nigeria is qualitative. It rarely relies on quantitative data because police crime statistics are not reliable, or not available, or not even published. Moreover, the training of

Nigerian social scientists often focuses on qualitative, cultural, and political issues. There is thus a need to bridge the qualitative and quantitative approaches of conflict studies.

This book represents an innovation and fills a gap in this regard. It is the first to introduce a discussion on such issues in a coherent manner, relying on a database that fills the lacunae in data from the security forces. The authors underline the necessity of a trend analysis to decipher the patterns and the complexity of violence in very different fields: from oil production to cattle breeding, radical Islam to motor accidents, land conflicts to witchcraft, and so on. In addition, they argue for empirical investigation and a complementary approach using both qualitative and quantitative data. The book is therefore organized into two parts, with a focus first on statistical studies, then on fieldwork.

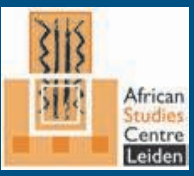

www.ascleiden.nl 